\title{
Site U1346
}

\author{
Expedition 324 Scientists $^{2}$
}

\section{Chapter contents}

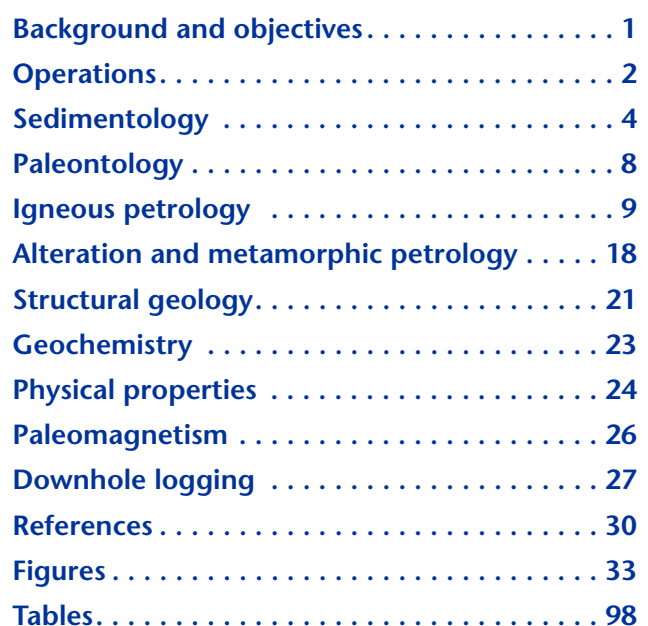

${ }^{1}$ Expedition 324 Scientists, 2010. Site U1346. In Sager, W.W., Sano, T., Geldmacher, J., and the Expedition 324 Scientists, Proc. IODP, 324: Tokyo (Integrated Ocean Drilling Program Management International, Inc.).

doi:10.2204/iodp.proc.324.103.2010

'Expedition 324 Scientists' addresses.

\section{Background and objectives}

\section{Background}

Integrated Ocean Drilling Program Site U1346 (proposed Site SRNH-2) on Shirshov Massif was the first and northernmost site drilled during Expedition 324 (see Fig. F1 in the "Expedition 324 summary" chapter). The expedition began with this site because of the necessity of working from north to south to minimize transit time. The site was proposed as the northernmost site in a transect of five holes across the large volcanic edifices of Shatsky Rise. As with all sites during Expedition 324, the goal was to core through the lowermost sediments and into igneous rocks, recovering as much of the latter as possible in the allotted time.

Sampling Shirshov Massif was considered important because of the location of the volcano within Shatsky Rise. Magnetic lineations imply that Shatsky Rise formed along the trace of a triple junction (Sager et al., 1988; 1999; Nakanishi et al., 1999) and volcanism appears to have followed the track of the triple junction (or vice versa), but the amount of volcanism appears to have diminished over time. Shirshov Massif appears to be one of two intermediate volcanic edifices between the initial eruptions of Tamu Massif, on the southwest end of the rise, and the waning volcanic trail of Papanin Ridge on the northeast end of the rise. Thus, Shirshov Massif is important in the study of Shatsky Rise because it represents the transitional, waning magmatic output of the rise volcanism. In the parlance of the plume head hypothesis, Shirshov Massif is in the transition between plume head and tail.

Shirshov Massif is the northernmost of the large seamounts within Shatsky Rise. It is a subcircular edifice, $\sim 100 \mathrm{~km}$ in diameter with a minimum depth slightly less than $3 \mathrm{~km}$ (Fig. F1). Seismic sections show thin or absent sedimentary cover on the volcano flanks but a thick volcanic cap atop the summit with the thickest part at the center of the edifice (Sager et al., 1999). Seismic data also show moderately strong acoustic basement across the edifice, with the basement being mostly flat except for some buried ridges that may define the boundaries of a buried caldera or summit depression.

Site U1346 is on the north rim of the summit of Shirshov Massif (Fig. F1) and is the only site drilled on Shirshov Massif during Expedition 324. Ocean Drilling Program (ODP) Leg 198 Site 1207 (Fig. F1), $26 \mathrm{~km}$ southeast of Site U1346 near the center of the sediment cap, is the only other site drilled on Shirshov Massif. It 
was cored for paleoceanographic objectives, and drilling reached only through the Upper Cretaceous sediments (Shipboard Scientific Party, 2002a). Site U1346 was situated along the Cruise TN037 site survey seismic Line 5A (at 2130Z on 9 August 1994; see Klaus and Sager, 2002) at a point where sediments thin toward the edge of the summit platform (Fig. F2). At this location, the igneous basement interface was interpreted to be flat and at $\sim 177$ meters below seafloor (mbsf). The rationale for choosing this location was that the igneous basement seemed to be free of structures that might indicate tectonic disturbance or late-stage volcanism and that the sediments were thick enough to support the bottom-hole assembly (BHA) but thin enough that minimal time and bit wear would need to be expended in reaching igneous basement.

Magnetic lineations mapped around Shatsky Rise bracket Shirshov Massif, with M13 on the north side of the edifice and M15 on the south side (see Fig. F3 in the "Expedition 324 summary" chapter; Nakanishi et al., 1999). Site U1346 is near the location of Anomaly M14, but the exact location of the anomaly is poorly known because magnetic tracks are sparse over Shirshov Massif. If the basement of the volcanic edifice is the same age as the anomaly, its age is 140 Ma and corresponds to a time near the boundary between the Valanginian and Berriasian stages of the fossil timescale (Ogg et al., 2008).

\section{Scientific objectives}

Sampling Shirshov Massif was an important objective because this volcano is the farthest north of the large volcanoes within Shatsky Rise. As with most Expedition 324 sites, the operational goal for Site U1346 was to drill through the sediment overburden, core the oldest sediment overlying igneous basement, and core as deeply into the igneous formation as possible with a single rotary core barrel (RCB) bit. Precruise plans anticipated coring $~ 100 \mathrm{~m}$ into the igneous basement.

Scientific objectives of Expedition 324 sites are similar (for more details and rationale, see the "Expedition 324 summary" chapter). Coring of igneous rock was planned to determine the age of igneous basement so that the age progression and duration of volcanism at Shatsky Rise can be constrained. A critical objective at Site U1346 was to core enough igneous rock of suitable freshness and composition to allow a reliable radiometric date to be established. Igneous rocks are also critical to geochemical and isotopic studies whose goals are to establish the elemental compositions of the rocks, variations in compositions, and the isotopic characteristics. Such data are crucial to determine the source of magma, to in- fer its temperature and depth of melting and crystallization, and to deduce the degree of partial melt, as well as to track its evolution with time. Operationally, this meant that at Site U1346 the goal was to core a representative suite of igneous units that were also only lightly altered so as to be suitable for geochemical and isotopic measurements.

Expedition 324 also sought to constrain the evolution of Shatsky Rise by collecting samples for a host of nongeochemical studies focusing on varied aspects of rise geology. Physical volcanologists, structural geologists, and logging geophysicists will use cores and logs to infer the eruption style, igneous products, and physical structure of Shatsky Rise. Given its size and inferred eruption rate, Shatsky Rise is likely to be an example of an unusual volcanic construct for which development is poorly understood. Shirshov Massif, with its intermediate size, is important for understanding the development of large igneous province (LIP) volcanoes that are bigger than normal seamounts but smaller than large plateaus. Shatsky Rise core samples will also be used to study the submarine alteration of igneous rock and its effect on other analyses. Studies of sediments overlying igneous basement are planned to better understand the paleontological age of Shatsky Rise sediments and the processes and rates of Cretaceous sedimentation atop the rise volcanoes. Moreover, sediment types and trends will indicate the paleodepths of sediment deposition, information that is important to understanding the eruption and subsidence history of the volcanic edifices. Paleomagnetic study of the samples recovered during Expedition 324 seeks to determine the magnetic polarity of basement for comparison with surrounding magnetic lineations and the geomagnetic polarity timescale, as well as the paleolatitude of the rise and its plate tectonic drift. Shirshov Massif samples are important in this effort because they were likely formed farthest from the paleoequator (i.e., higher paleoinclination) and thus are less likely to be confounded by uncertainty about whether the massif formed north or south of the Equator. Physical properties of Shatsky Rise core samples will be measured to better understand the nature of the rocks that make up the rise and to constrain fundamental physical properties that affect geophysical imaging and remote sensing. Such data will be useful for constraining seismic and gravity studies in particular.

\section{Operations}

Times in this chapter are given in local ship time. During transit to Site U1346, shipboard clocks were advanced $1 \mathrm{~h}$, resetting local ship time to Sydney 
Standard Time (Universal Time Coordinated +10 ). No further adjustments to the clock were made during the expedition.

\section{Yokohama port call}

Expedition 324 started on 4 September 2009 at the port of Yokohama, Japan, with the changing and crossover of Overseas Drilling Limited and Integrated Ocean Drilling Program personnel. Expedition 324 scientists boarded the ship on 5 September. In addition to the routine resupply of expendables and the offloading of Expedition 323 cores and returning freight, some items of note were the loading of 1800 MT of marine gas oil, overhaul of the passive heave compensator, and service visits by Novenco (air conditioning), RigNet (Very Small Aperture Terminal [VSAT]), and Hose-McCann (ship phone/intercom/alarm system) field engineers. This port call was also noteworthy for the extensive number of visitors that were treated to a tour of the vessel including visitors of the National Museum of Nature and Science in Tokyo, members of the Japanese scientific community, and U.S. embassy personnel. A press conference for Japanese and international media was held on 5 September.

During this $\sim 5$ day port call, we were not able to send or receive e-mail or use the ship's phone system because of local electromagnetic interference, which prevented VSAT operation. Although some maintenance was possible on the aft antenna, the RigNet engineer was unable to perform a systems check and calibration to the VSAT system because of the interference.

Once the last line was released at $0950 \mathrm{~h}$ on 9 September, the vessel was under way to the pilot station. The RigNet engineer stayed aboard and attempted last-minute adjustments while working with rigbased technicians. The pilot and RigNet representative disembarked at the pilot station at $\sim 1130 \mathrm{~h}$. A short time after this, VSAT operation was restored and remained until the first course change. At this time, the signal was lost and in spite of the best efforts of onboard technicians communicating with the RigNet engineer in the hotel using the Inmarsat GMDSS satellite phone, the VSAT system could not be restored to normal working order. A decision was made to reverse course, return to a convenient rendezvous point close to the head of Boso Peninsula, and bring the RigNet engineer back to work on the system.

The RigNet engineer was welcomed aboard shortly before $0600 \mathrm{~h}$ on 10 September and remained for nearly $2 \mathrm{~h}$ restoring the VSAT to operation. Once he departed at $0740 \mathrm{~h}$, the vessel began its voyage to Site U1346.

\section{Transit to Shatsky Rise and Site U1346 (Shirshov Massif)}

The R/V JOIDES Resolution came to position at Site U1346 at $0930 \mathrm{~h}$ on 14 September 2009. The 1129 nmi voyage from Yokohama, Japan, was accomplished at an average speed of $11.8 \mathrm{kt}$ and was without incident. The four-stand RCB drilling assembly was made up and deployed as the drilling crew performed the routine first site measuring and internal clearance check of each tubular.

After the driller tagged seafloor at $3630.0 \mathrm{~m}$ drilling depth below rig floor (Table T1; $2.6 \mathrm{~m}$ deeper than the corrected precision depth recorder depth), Hole U1346A was spudded with a center bit in place at $0140 \mathrm{~h}$ on 15 September. The hole was advanced to $71.0 \mathrm{~m}$ drilling depth below seafloor (DSF) at an average rate of penetration (ROP) of $20.8 \mathrm{~m} / \mathrm{h}$. During the course of drilling this interval, hard layers were encountered at 60.0, 67.0, and $71.0 \mathrm{~m}$ DSF and were assumed to be chert. The worn center bit was retrieved by coring line and replaced with a wash barrel. The hole was advanced by drilling ahead from 71.0 to $100.5 \mathrm{~m}$ DSF. The $29.5 \mathrm{~m}$ advance through chert layers was accomplished at an average ROP of $8.9 \mathrm{~m} / \mathrm{h}$. The wash barrel contained $0.21 \mathrm{~m}$ of chert including one nicely cored single-piece sample that was $\sim 15 \mathrm{~cm}$ in length.

Rotary coring was initiated at $100.5 \mathrm{~m}$ DSF and deepened the hole to a total depth of $191.8 \mathrm{~m}$ DSF by $0915 \mathrm{~h}$ on 18 September. Basaltic basement was contacted at $139.2 \mathrm{~m}$ DSF. Total penetration into basement was $52.6 \mathrm{~m}$ (Fig. F3). The average ROP for the cored interval was $2.0 \mathrm{~m} / \mathrm{h}$ with an average recovery of $28 \%$. The average ROP for basement coring was $1.3 \mathrm{~m} / \mathrm{h}$ with an average recovery of $38.7 \%$. Because of the slow penetration rate combined with the successful recovery of material suitable to address most of the objectives for this site, it was decided to end coring at this depth and prepare the hole for logging operations. An additional factor in the decision to cease coring operations at this site was the approach of Typhoon Choi-Wan.

Following a wiper trip and displacement of the hole with $38.5 \mathrm{bbl}$ of mud, the triple combination (triple combo) tool string was deployed on 18 September. The tools were able to log the open hole to within 10 $\mathrm{m}$ of the bottom of the bore. The poor condition of the hole and significant heave did not warrant deployment of the Formation MicroScanner (FMS)sonic tool suite. Logging tools were secured by 0845 $\mathrm{h}$ on 19 September.

The drilling assembly was pulled free of the seafloor and fully recovered. After the beacon was recovered from $20 \mathrm{ft}$ seas, the thrusters were retracted and the 
vessel departed for the $370 \mathrm{nmi}$ voyage to Site U1347 (proposed Site SRSH-3B) at $1800 \mathrm{~h}$ on 19 September. Because of the proximity of Sites U1348 and U1349 (proposed Sites SRCH-6 and SRSH-5, respectively) to Typhoon Choi-Wan's projected track, it was decided to proceed directly to the more southerly and higher priority site.

\section{Sedimentology}

One hole was cored at Site U1346 on the northeast flank of Shirshov Massif (water depth $=3619$ meters below sea level [mbsl]). The primary goal of drilling at this site was to recover the basaltic basement estimated to reside below $140 \mathrm{mbsf}$; therefore, sediment coring began only $\sim 39 \mathrm{~m}$ above the suspected basement/sediment interface. Despite difficult drilling conditions, $\sim 4 \mathrm{~m}$ of sediments were recovered prior to entering basaltic basement at $139.2 \mathrm{mbsf}$. The first six cores recovered from Hole U1346A contain sedimentary material representing various lithologies and depositional environments, with an average recovery of $10.2 \%$ between 100.5 and 141.7 mbsf. The uppermost sedimentary section (Cores 324-U1346A-1W through 3R) yielded only small, isolated, dark-colored chert fragments. Recovery in Cores 324-U1346A-4R through 6R improved because of a reduction in the amount of chert in the formation. This short interval of lithified sediments included a sequence of intermingled basalt and limestone in Section 324-U1346A-4R-1 interpreted as a debris flow. Section 324-U1346A-4R-2 yielded a series of laminated volcaniclastic sequences, grading from very coarse sand to clay, interpreted as turbiditic in origin. The remaining sediments, from the base of Section 324-U1346A-4R-2 to the top of 6R-1, are composed of clay-bearing limestones and calcareous mudstones containing abundant shell fragments and other biogenic components, along with glauconite and altered volcaniclastics. Taken together, these components are suggestive of a relatively shallow marine depositional environment in close proximity to a volcanic source.

\section{Unit descriptions}

Within the $\sim 4 \mathrm{~m}$ of sediment recovered between 100.5 and 139.2 mbsf in Hole U1436A, four units can be identified (Fig. F4), although the relationship between these units is ambiguous because of the loss of interunit contacts:

- Unit I: Chert-bearing strata between 100.5 and 110.1 mbsf, presumably interbedded cherts and softer calcareous sediments (not recovered).

- Unit II: Basalt-limestone breccia sequence between 119.5 and 121.0 mbsf, featuring inter- mingled highly altered vesicular basalt and hemipelagic limestone.

- Unit III: Laminated and normally graded volcaniclastic sequences between 121.0 and 121.9 mbsf, likely turbiditic in origin and representing at least three discrete depositional events.

- Unit IV: Bioclastic clay-bearing limestones and calcareous mudstones between 122.0 and 139.2 mbsf, featuring abundant benthic fauna such as bivalves and sponges, with authigenic glauconite and volcaniclastics as consistent minor components.

\section{Unit I}

Interval: 324-U1346A-1W through 3R-CC

Depth: 100.5-110.1 mbsf

The large chert piece $(16 \mathrm{~cm})$ recovered in Core 324U1346A-1W is brownish gray, with fine laminations visible in places. A band of shell fragments, originally calcitic in composition and now entirely composed of silica, suggests complete replacement of the original carbonate matrix by cryptocrystalline silica during diagenesis. The additional chert in Cores 324U1346A-1W through 3R is black with faint laminations and includes rare silica-replaced shell fragments in places. Traces of the softer sediments, which presumably interbed with the indurated chert horizons, are observed only as occasional thin $(<1$ $\mathrm{mm}$ ) chalk coatings on the chert fragments in Core 324-U1346A-2R. Because of extensive disturbance and fragmentation introduced by the drilling process, no other soft sediments were recovered.

\section{Unit II}

Interval: 324-U1346A-4R-1 through 4R-2

Depth: $119.5-121.0 \mathrm{mbsf}$

The upper $1.2 \mathrm{~m}$ of Core 324-U1346A-4R features highly altered, vesiculated, green basalts intermingled with fine-grained, radiolarian-bearing limestones. The limestones are predominantly composed of fine sparite, probably formed from the recrystallization of nannofossil ooze, as a small percentage of poorly preserved nannofossils now remain as a minor component. Two different colors of limestone are observed in this interval, grayish brown and very dark gray, with higher clay content relative to carbonate in the darker bands. The boundary between these two limestone types is convoluted and deformed, especially where in close proximity to the basaltic lobes.

Moderately preserved, unidentified radiolarian fossils are present throughout the limestone but are particularly numerous and well preserved in the darker clay-rich bands (Fig. F5). A large $(\sim 3 \mathrm{~cm})$ fossil frag- 
ment, possibly representing fish debris, is present in Section 324-U1346A-4R-1. Small pieces of apatite debris and fine shelly remains are present within the limestone, as are small isolated clasts of basalt in some horizons. There is no evidence of bioturbation in the form of burrows; however, the sediment does appear to be homogeneous and well mixed, which is suggestive of an oxic, bioturbated depositional environment. Secondary pyrite is visible as small crystals throughout the limestone, and it is concentrated as fine bands in the darker clay-rich layers.

The contact between the basalt and the sediments is convoluted (Fig. F6). The basalt appears to have intruded into the limestone in places, although there is no evidence of chilled margins in the basalt or baked sediment at the contacts. The original bedding in the limestones between the lighter and darker lithologies is contorted, providing evidence of soft-sediment deformation prior to lithification.

\section{Unit III}

Interval: 324-U1346A-4R-2

Depth: 121.0-121.9 mbsf

A $90 \mathrm{~cm}$, finely laminated sand-silt-claystone interval in Section 324-U1346A-4R-2 contains several fining-upward sequences of medium sand grading to clay-sized particles (Fig. F7A). The dominant constituents in this sequence are clay minerals and volcanic glass with varying contributions from radiolarians, iron oxyhydroxides, and glauconite throughout. The volcanic glass fragments are on the order of $100 \mu \mathrm{m}$ in size and are generally angular in shape (Fig. F7B).

The coarser horizons within the graded sequence are predominantly composed of clays, carbonate, and detrital glass but also contain a significant number of moderately preserved radiolarians in some horizons. In some instances the skeleton of the organism is composed of fine-grained secondary silica, allowing delicate features such as wall structures and spines to be observed. In other cases the silica has been entirely replaced by sparite, leading to a corresponding decrease in preservation quality. At the base of the sequence, an isolated piece of calcite-cemented volcanic breccia contains large $(0.5-1 \mathrm{~mm})$ altered feldspar laths and fragments of mafic volcanic rock. These fragments are rounded and contain numerous needlelike feldspar laths in a dark glassy matrix (Fig. F7C).

There are three major fining-upward sequences, with possibly as many as seven minor graded sequences overall. Each sequence likely represents a discrete depositional event. The laminations are well preserved throughout indicating an absence of bioturbation, except for one claystone layer at the top of the sec- ond fining-upward sequence from the bottom (interval 324-U1346A-4R-2, 107-108 cm), where the trace fossil Chondrites can be seen (Fig. F7D). The base of this second sequence has an erosional contact with the fine clays beneath it and a scour mark filled with coarser, medium sand-sized grains. Flame structures and convolute lamina in clay-silt sized material at the top of the uppermost sequence can also be seen (Fig. F7E).

\section{Unit IV}

Interval: 324-U1346A-4R-2 through 6R-1

Depth: $122.0-139.2 \mathrm{mbsf}$

This unit extends from the uppermost part of Section 324-U1346A-6R-1 to the base of $4 \mathrm{R}-2$ and is composed predominantly of bioclastic limestones and calcareous mudstones. At the base of the unit, just above the sediment/basement contact, a heavily recrystallized, pale gray limestone piece with steeply inclined laminations contains altered grains of green glauconite. Above this, spanning Sections 324U1346A-6R-1 and 5R-1, gray indurated limestones containing shell fragments, including the well-preserved outer whorl of an unidentified ammonite, are observed. The suture lines of the ammonite shell are clearly visible in some orientations. These gray limestones are quite "clean" and consist almost exclusively of recrystallized carbonate with only a minor clay component. The remainder of the unit, from Section 324-U1346A-5R-1 to the base of $4 R-2$, is a mixed sequence of laminated limestones and calcareous mudstones. Apart from a coarse bioclastic piece consisting largely of inoceramid bivalves at interval 324-U1346A-4R-2, 138-142 cm, limestones from the lower part of Core $4 \mathrm{R}$ to the upper $6 \mathrm{~cm}$ of Section 5R-1 are finely laminated and have less glauconite and fewer shell fragments than the underlying muddy limestones in Section 5R-1.

The matrix of the bioclastic limestones is largely composed of micrite with associated clay minerals, although secondary sparite cement is present in some horizons. Soft calcareous mudstones are a common feature of Core 324-U1346A-5R. This lithology has a higher proportion of clay minerals relative to the limestones stratigraphically above and below and is accordingly less well indurated, which led to extensive drilling disturbance in some intervals. Some of the calcareous mudstones are dark brownish gray, suggesting an increased proportion of organic matter, which is supported by weight percent total organic carbon (TOC) measurements taken in this interval (Table T2). A significant spike in the uranium content of the sediments in the calcareous mudstone section of Section 324-U1346A-5R-1, be- 
tween 50 and $70 \mathrm{~cm}$, also supports this observation (see "Physical properties").

Green glauconite pellets are present throughout this unit and are especially abundant in Core 324U1346A-5R, where they appear as subrounded to subangular clasts within the carbonate matrix. A concentration of these clasts is present at $129.2 \mathrm{mbsf}$ at the base of a dark grayish brown nannofossil-rich mudstone. Small plagioclase feldspar laths are a common minor component of many of the limestones and are generally subangular in shape. Radiolarians, present throughout the sequence, have often been replaced by calcite and are generally not well preserved. Traces of a diverse epifaunal assemblage including bivalves, gastropods, sponges, benthic foraminifers, and possible echinoderms can be seen in the calcareous mudstones of Core 324-U1346A-5R (Fig. F8). Fragments of inoceramid bivalves are a common component of this unit and in some instances constitute a significant percentage of the carbonate content of the limestone (Fig. F8A). Small dark-colored elongate fragments, tentatively identified as wood, were found in this unit. These elongate fragments are concentrated in the calcareous mudstones in Section 324-U1346A-4R-CC and at the top of 5R-1 but were also identified in the laminated limestones from this interval.

\section{Sedimentary carbon content}

Six samples were taken from Cores 324-U1346A-4R through $5 \mathrm{R}$ to determine total carbon, carbonate $\left(\mathrm{CaCO}_{3}\right)$, and TOC content in weight percent (Table T2). Prior to analysis, sediment samples were scraped to remove surface contamination then freeze-dried and powdered to remove water and ensure complete homogenization. Carbonate content was determined by acidifying $\sim 10 \mathrm{mg}$ bulk sediment samples with 2 $\mathrm{N} \mathrm{HCl}$ and measuring the $\mathrm{CO}_{2}$ evolved with a UIC Coulometer. $\mathrm{CaCO}_{3}$ content ranged from $3.5 \mathrm{wt} \%$ $( \pm 0.2 \mathrm{wt} \% ; 2 \sigma)$ to $98.4 \mathrm{wt} \%( \pm 0.8 \mathrm{wt} \% ; 2 \sigma)$. All of the samples measured contained $>25 \mathrm{wt} \%$ carbonate with the exception of one taken from the finely laminated sand-silt-claystone at interval 324-U1346A$4 \mathrm{R}-2,61-63 \mathrm{~cm}$, composed primarily of volcaniclastics.

Total carbon content was determined by combustion of the sample at an initial temperature of $900^{\circ} \mathrm{C}$ in a Thermo Electron Corporation, Flash EA 1112 Series carbon-hydrogen-nitrogen-sulfur (CHNS) analyzer. This value was used to calculate TOC content by subtracting the percentage carbon as carbonate value obtained from coulometric analysis from the total carbon content value obtained from the CHNS analyzer.
TOC contents at Site U1346 were low, averaging 0.5 wt $\%( \pm 1.1 \mathrm{wt} \% ; 2 \sigma)$. Only one sample, taken from a dark grayish brown nannofossil-rich calcareous mudstone (interval 324-U1346A-5R-1, 12-13 cm), contained $>0.5 \mathrm{wt} \%$ organic carbon.

\section{Interpretation}

Poor recovery in the sedimentary section of this site and the loss of contacts between different stratigraphic units makes interpreting the exact sequence of events leading to the deposition of the sediments challenging. In addition, the ages of the different units at this site are not well constrained because of the general lack of age-diagnostic species typically used in biozonation (see "Paleontology"). This also leads to difficulty in estimating diagnostic lithologic features such as sedimentation rates. The available age models, however, do suggest an Early Cretaceous (Berriasian to early Hauterivian) age for sediment deposition in stratigraphic Units I-IV, which correlates well with the estimated basement age for Shirshov Massif from magnetic lineation studies in the region (Nakanishi et al., 1999).

In general, the lithology and fossils of the sediments recovered in Units I-IV suggest progressively shallower paleodepths of deposition with increasing depth in the core. This observation is in agreement with the model of a subsiding volcanic edifice, where the oldest sediments above basement are deposited in the shallowest water depth with subsequent younger sediments deposited in progressively deeper marine settings (e.g., Winterer and Sager, 1995). The presence of significant amounts of carbonate throughout Units I-IV precludes deposition below the carbonate compensation depth (CCD). In addition, the presence of numerous lithologic and paleontological water-depth indicators in Unit IV provides further support for a relatively shallow marine depositional environment. The presence of possible wood fragments and numerous reddish rock fragments identified as scoria (oxidized pyroclastics) are suggestive of an emergent, possibly vegetated, volcanic land mass in close proximity to the depositional area.

The reconstructed paleoenvironments of Units II and III are more complicated to interpret, as the lithologic features observed could be interpreted in several different ways and may have been influenced by the specific unknown local conditions at this site. The presence of volcanic materials such as glass and feldspar, found throughout the graded sand-silt-claystone sequence, suggests the site was in fairly close proximity to the volcanic source during deposition of Unit III, either directly through eruptions or indi- 
rectly through weathering of previously erupted basaltic lavas. Paleogeographic reconstructions place the location of Shatsky Rise in the equatorial paleoPacific during the Early Cretaceous, thousands of kilometers away from any terrigenous source of material (e.g., McNutt and Fischer, 1987). This observation suggests that any significant source of nonpelagic sediment, such as the abundant claysand sized material found in Unit II, must have had a more proximal, and probably volcanic, source.

The origin of Unit II, which includes the mixed basaltic and limestone lithologies, is again puzzling. Despite the intermingling of the basalt with the deformed limestone, the absence of chilled margins where the basalt is in contact with the sediment suggests that the basalt had already cooled and partially solidified when it encountered the calcareous sediments. With regard to the depth of emplacement, the high vesicularity of the basalt might suggest relatively shallow depths $(<300 \mathrm{~m})$, whereas the lithology of the intermingled limestone suggests a deeper, more pelagic setting.

\section{Unit I}

This unit, for which we have very limited core recovery, is thought to represent deposition in the Early to mid-Cretaceous. At Site U1346, Unit I seems to be composed of interbedded soft nannofossil chalks and indurated radiolarian chert beds, which contribute to the poor recovery of this unit.

The chert beds of this unit are the result of remobilization of biogenic silica, most likely sourced from radiolarian tests. The occasional nannofossil chalks, which occur as thin coatings on the cherts, suggest an oxic, pelagic environment where deposition occurred well above the CCD. The high abundance of silica and radiolarian "ghosts" suggests the site was close to an area of high productivity during the time of deposition, probably related to equatorial upwelling.

\section{Unit II}

The limestone recovered in Section 324-U1346A-4R1 was likely deposited in a hemipelagic to fully pelagic setting because of the fine texture of the matrix and lack of shelly or sandy material indicative of very shallow marine settings. The high carbonate content ( $>90 \mathrm{wt} \%$ ) of these sediments and the presence of nannofossils indicates deposition well above the CCD. Fine laminations, preserved where the bedding has not been disturbed, and the contribution of both radiolarians and nannofossils to the sediments in the absence of large bioclasts suggests quiescent waters certainly deeper than storm wave base and possibly as deep as 700-1000 mbsl. It is possible that the lack of shelly material, however, is caused by the entire carbonate-bearing platform having subsided below the point where shallow-water fauna such as bivalves could thrive in abundance, leading to a lack of such material in adjacent sediments deposited at modest depths (300-400 mbsl).

Where the highly vesiculated basalt intermingles with the sediments, bedding features become convoluted and deformed. All of the sediments in this unit are cemented with carbonate, and much of the material in close proximity to the volcanic rock appears to be recrystallized nannofossil ooze, suggesting diagenetic alteration caused by heating or changes in pore water chemistry. The basalt lacks chilled margins, which is evidence that the rock material solidified prior to contact with the soft sediments. The basalt could have been emplaced as a flow from a latestage flank eruption, whereupon it cooled, solidified, and slumped into an area of carbonate sedimentation. This would have caused some soft-sediment deformation to the carbonates without destroying the original bedding, which is still evident in the limestones. This model also accounts for the presence of basaltic clasts within the sediment package, the seeming disparity in igneous versus sedimentary depositional depths, and the lack of glassy cooling texture in the basaltic lobes where they are in contact with the sediments.

\section{Unit III}

Unit III consists of several normally graded, sand to clay fining-upward sequences, which we interpret as representing deposition from subaqueous mass movement events, most likely the action of turbidity currents. The finely laminated sequences and normal grading are indicative of hydraulic sorting processes. The presence of scours and flame structures suggests lateral and rapid emplacement of material from a flow rather than passive settling through the water column. The low carbon content of the sediments and abundant clay and angular glass fragments throughout points to a proximal volcanic source. As the largest grains in the fining-upward sequences are medium sand, the depositional environment most likely represents the distal lobe of a turbidity fan rather than deposition close to the source of the events. The coarsest material in the sequence occurs as an isolated piece at the base of the lowermost graded sequence, which may represent the coarse basal unit of an earlier, more proximal turbidity current event.

As the presence of basaltic lava in Unit II clearly indicates active volcanism in the immediate vicinity after the deposition of Unit III, it is not unreasonable to suppose that sediments accumulated on the steep 
sides of a volcanic plateau where they could be destabilized by successive eruptions and form large debris flows. The isolated bioturbated horizon in the fine claystone at the top of one graded sequence indicates oxic to suboxic conditions and a period of quiescence before the arrival of the next depositional event. Paleodepth is estimated to be $>500 \mathrm{mbsl}$, based on the lack of shallow-water carbonate material, the size of the volcanic material deposited, and the degree of hydraulic sorting exhibited in the sequence. This estimate, however, is uncertain because of the unknown height and incline of the original volcanic platform, which would influence the depositional pattern of this sequence.

\section{Unit IV}

This unit represents the oldest sedimentary material recovered at Shirshov Massif and is interpreted as being deposited in a shallow marine setting. Water depth may have been 150-200 mbsl or as shallow as 50 mbsl, based on assorted lithologic and biological information, including paleodepth estimates from benthic foraminifer assemblages (see "Paleontology"). The presence of epifaunal biota such as bivalves, gastropods, and possibly echinoderms, all commonly associated with shallow-water marine environments, is strongly suggestive of shallow water depths during deposition of Unit IV. The shelly remains are not preserved in life position and so probably represent the debris from the proximal very shallow water environment where they were living. The authigenic mineral glauconite, which is abundant throughout this unit, is found in the modern world exclusively in marine environments. It is often associated with organic matter, especially within fecal pellets, and often replaces biogenic structures such as foraminifer shells. Glauconite is often considered to require mildly reducing conditions and a reasonably low sedimentation rate in order to precipitate and has been used to infer such conditions for periods of ancient deposition (Harder, 1980). Attempts have also been made to infer paleodepth based on glauconite because of its restriction of formation in the modern oceans to the shelf and upper slope (50-500 mbsl). However, some recent work suggests constraints on modern glauconite formation may not hold true for formation in the past; therefore, glauconite cannot be considered a robust paleodepth indicator (Chafetz and Reid, 2000). Caution should perhaps then be exercised in inferring depth information from its presence in the case of Site U1346, although mildly reducing conditions associated with decaying organic matter at depths from 50 to 500 mbsl throughout the sequence would not be at odds with other lithologic and paleonto- logical information. The presence of suspected wood fragments in Core 324-U1346A-5R leads us to conclude that there may have been emergent vegetated land in the vicinity, probably associated with the earlier volcanic edifice building event. If the grains associated with the basal limestones are indeed volcanic scoria, this may be indicative of subaerial eruptions (see "Igneous petrology"), which lends weight to the interpretation of emergent land close to the area of deposition at Site U1346.

\section{Paleontology}

Sediments from Site U1346 (Cores 324-U1346A-1W through 6R) are lithologically variable (stratigraphic Units I-IV; see "Sedimentology") and more or less lithified, yet relatively unconsolidated marly/chalky portions are present in Units III (calcareous mudstones/sandstones) and IV (limestones). These levels were chosen for shipboard calcareous microfossil studies. In addition, calcareous nannofossils were investigated for such lithologies as carbonate-poor sandstones (Unit IV) and chert-encrusting limestones (Unit II).

Lower Cretaceous (Berriasian-Hauterivian) calcareous nannofossils with moderate to poor preservation were retrieved from most of the examined levels in Cores 324-U1346A-2R through 6R irrespective of the lithologic differences (stratigraphic Units II-IV). Foraminifers were obtained from the marly lithology of Section 324-U1346A-4R-CC, although the planktonic group was completely absent. Accordingly, the primary biostratigraphic age control for Site U1346 sediments was developed solely using the nannofossil assemblage analysis. Benthic foraminifers from Section 324-U1346A-4R-CC were well preserved and diverse, predominantly from the neritic-upper bathyal assemblage (estimated paleodepth $\leq 500$ mbsl).

Various biogenic sedimentary components were observed in the samples processed for foraminifer analyses, which are predominantly radiolarians (recrystallized to calcite) and subordinately ostracodes, inoceramid prisms, echinoid plates, sponge spicules, bryozoans, and carbonaceous fragments (presumably of terrestrial higher plant origin). Noteworthy is the presence of articulated ostracodes indicating autochthonous burial.

\section{Calcareous nannofossils}

Calcareous nannofossils in the sediments from Site U1346 are rare to abundant and moderately to poorly preserved. All stages of overgrowth and etching were found. 
The uppermost part of the sediments (Unit I) is represented by black chert pieces encrusted by limestone to a small extent. This limestone (Sample 324U1346A-2R-1, $1 \mathrm{~cm}$ ) contains Cruciellipsis cuvillieri (Fig. F9A, F9B), and Speetonia sp. (Fig. F9C, F9D), as well as Cretarhabdus striatus, which implies a mixture of calcareous nannofossil taxa of the entire Cretaceous (Berriasian-Maastrichtian) (Table T3) within the sample. In contrast, a considerable number of well-preserved coccospheres (Fig. F9E, F9F) are observed in Sample 324-U1346A-2R-CC, $1 \mathrm{~cm}$ (chert pieces), which points to autochthonous deposition. The limestone of Unit II contains a small number of poorly preserved Watznaueriaceae, for which age determination is not possible as they occur through the entire Cretaceous. Beneath, a graded sequence (interpreted as turbiditic in origin) of Unit III contains a nannofossil assemblage that again ranges through the entire Cretaceous (Samples 324-U1346A-4R-2, 27-30 cm, and 4R-2, 107-108 cm) (Table T3).

In the underlying clay-rich limestone of Unit IV, the occurrence of Eprolithus antiquus allows the assignment of Sample 324-U1346A-4R-2, $140 \mathrm{~cm}$, to Subzone NC4a (early Hauterivian) (Table T3; see "Paleontology" in the "Methods" chapter), whereas Sample 4R-CC, $3 \mathrm{~cm}$, indicates an Early Cretaceous range (Table T3). The next fossiliferous sample below is a shell-rich limestone bed (Sample 324-U1346A5R-1, 53-54 cm) (Table T3) that yields Rotelapillus laffittei (Fig. F9G, F9H). Based on the nannofossil assemblage the age of this sample is assignable to Subzones NK2a to NC5a-NC5b (Berriasian-early Hauterivian). This assignment is consistent with the occurrence of E. antiquus (Subzone NC4a; early Hauterivian) in Sample 324-U1346A-5R-CC, 24-25 cm. The lowermost Sample 324-U1346A-6R-1, 24-25 cm, yields a large number of heavily overgrown Watznaueriaceae, which again prevents accurate age determination.

In summary, the age of the middle-lower part of stratigraphic Unit IV (Samples 324-U1346A-5R-1, 53-54 $\mathrm{cm}$, to $6 \mathrm{R}-1,23 \mathrm{~cm}$ ) is most likely $142-128 \mathrm{Ma}$ (the base of Subzone NJKd to the base of Zone NC5). This indicates that the age of basement basalts is 142-128 Ma or older.

\section{Foraminifers}

Well-preserved foraminifers with hollow tests were successfully obtained from two marly samples (324U1346A-4R-CC, 3-4 cm, and 4R-CC, 7-8 cm); four other examined samples were indurated and/or not sufficiently disaggregated (Table T4).

The foraminifer assemblage is characterized by the complete lack of planktonic foraminifers, even in the finer $63-150 \mu \mathrm{m}$ sediment fraction. Two expla- nations are possible for this observation: (1) the examined levels are pre-Aptian in age (as deduced from the calcareous nannofossil zonation), prior to the major planktonic foraminifer evolution in terms of abundance, diversity, and test size; and/or (2) the overwhelmingly large population of radiolarians induced an ecological bias in the zooplankton community.

Benthic foraminifers are diverse and comprise the neritic to upper bathyal assemblage (Table T4). Ten calcareous genera were identified: Dentalina, Laevidentalina, Frondicularia, Lenticulina, Saracenaria, Astacolus, Vaginulinopsis, Citharina, Planularia, and Psilocitharella. These genera are all placed under the family Nodosariidae according to Loeblich and Tappan (1988). Bolli et al. (1994) and Holbourn and Kaminski (1997) attributed the latter seven genera to the family Vaginulinidae. The nodosariids (or nodosariids and vaginulinids) have been known to dominate in the neritic to upper bathyal setting (e.g., Sliter and Baker, 1972; Sliter, 1977; Koutsoukos and Hart, 1990). Accordingly, the estimated paleodepth for stratigraphic Unit IV (see "Sedimentology") of Site $\mathrm{U} 1346$ is $\leq 500$ mbsl.

\section{Igneous petrology}

A key objective of Expedition 324 was to collect information regarding the nature of "basement" volcanic rocks on Shatsky Rise in the northwest Pacific. This basement was previously cored during Leg 198 at Site 1213 on the southern high (Tamu Massif) and revealed a series of fine-grained massive volcanic flow units, each several meters thick (Shipboard Scientific Party, 2002b).

Hole U1346A was drilled on Shirshov Massif, northeast of Tamu Massif, and established that a stack of highly vesicular basaltic pillow lavas or lava "inflation units" (stratigraphic Unit V) occurs beneath a succession of pelagic nannofossil-bearing chalks and cherts (stratigraphic Unit I), volcanogenic silts and sands, and larger volcaniclastic debris materials (stratigraphic Unit II). The latter volcaniclastic deposit occurs interbedded with sediment and is interpreted as a solidified "blocky" volcanogenic debris flow (stratigraphic Unit II). In this unit soft-sediment deformation occurs around the larger volcanic clasts indicating that the clasts impacted the sediment, either rolling downslope from its eruption sources or as a mass flow deposit generated through posteruptive erosion of the volcanic edifice. The presence of a deposit of volcanogenic sand and turbidites (stratigraphic Unit III) supports this latter interpretation. Within the lava stack, individual pillow (or inflation) units were readily identified by the presence of 
chilled glassy margins, upper and lower chill zones, characteristic pillow vesicle patterns, and crystal grain size variations. In Unit V, 40 individual "lava cooling units" were recognized in the retrieved core and together are interpreted to represent a single eruptive event.

The basalts from Unit IV appear aphyric macroscopically, but a closer inspection reveals that, where originally present as microphenocrysts, olivine and pyroxene are now totally replaced by calcite. All samples contain large proportions of less altered, very fine grained plagioclase laths set in a variolitic matrix. The pillow basalts are generally vesicular in nature and have zones that are moderately vesicular (30\%-50\% vesicles). Alteration has left a marked impression on the igneous rocks, is highly variable, and in some places is pervasive, ranging from less altered dark gray basalts in pillow unit cores to near completely altered and oxidized brown vesicular basalts. Green and brown clays, together with pyrite and iron oxyhydroxides, are the main secondary phases of the highly altered basalts and replace the primary phases as well as the entire glassy mesostasis. Minor pyrite and calcite are also observed associated with the groundmass clays, as well as in veins, especially in the upper $10 \mathrm{~m}$ of the basalt.

\section{Stratigraphic unit division}

In this site report, larger "stratigraphic units" are given Roman numbering (stratigraphic Units I-V), whereas small-scale "lithologic units" are identified by Arabic numbering (lithologic Units 1-58). We identified lithologic units on the basis of lithology changes, volcanological features (e.g., presence of contacts, chilled margins, and flow tops), changes in primary mineralogy (e.g., abundance of plagioclase, pyroxene, olivine, and oxide minerals), vesicle distribution, color, grain size, structure, alteration, and the presence of volcaniclastic or sedimentary interbeds. In the case of volcanic rocks, these lithologic units typically reflect different volcanic inflation or cooling units. Stratigraphic units, however, may combine these lithologic units into a single volcanic succession, or stack, of inflation units (see "Igneous petrology" in the "Methods" chapter for more details).

Hole U1346A was drilled on Shirshov Massif in the northwest of Shatsky Rise (Fig. F1). Igneous basement was reached at 139.2 mbsf, marking the first instance that volcanic basement samples have been sampled on Shirshov Massif. The cored succession consists of $69.7 \mathrm{~m}$ of volcaniclastic-rich sediment, volcaniclastics, and pillow basalt units preserved below a poorly recovered sedimentation succession (stratigraphic Unit I) consisting of chalk and chert (Fig. F10).

Volcaniclastic material was first encountered in Sections 324-U1346A-4R-1 and 4R-2 (119.5-122.0 mbsf) and comprises intercalations of fragmental basaltic debris and sediment containing a moderate to high proportion of crystalline and lithic igneous components. Fluidal mixing of sediment and basaltic clast material at specific horizons is indicative of active interaction between unconsolidated sediment and, possibly, still-plastic lava. Below this volcaniclastic debris unit, Core 324-U1346A-5R contains a finely laminated volcaniclastic turbidite sequence (stratigraphic Unit III) underlain by a section of bedded, sand-sized carbonate sediments, which continues to the top of Section 324-U1346A-6R-1 (stratigraphic Unit IV). Below 139.2 mbsf only igneous material was recovered (Sections 324-U1346A-6R-1 through 16R-1), dominated by highly vesicular aphyric micro- to cryptocrystalline basaltic eruptive pillows and lobes that have been pervasively altered (stratigraphic Unit V). This final unit we considered "true" Shirshov Massif basement.

\section{Chalk and chert (stratigraphic Unit I, lithologic Units 1 and 2)}

The first lithologic unit recovered in Hole U1346A was soft gray chalk interbedded with remarkably resistant layers of black and brown chert. The largest fragment recovered was $0.16 \mathrm{~m}$ of chert core, with only a very low recovery of the host carbonate. See "Sedimentology" for a more detailed description of this unit.

\section{Volcaniclastic debris (stratigraphic Unit II, lithologic Units 3-7)}

Unit II consists of vesicular basalt in the form of lava flow fragments with characteristic green-blue alteration (see "Alteration and metamorphic petrology" for more details) intercalated and intermingled with hemipelagic limestones containing moderate to high proportions of crystalline and lithic igneous components (Fig. F11). Within this $1.6 \mathrm{~m}$ thick basalt-limestone sequence, the nature of the contact between these two distinct lithologies is that of disturbed sedimentary structures indicative of fluidal mixing of soft sediment and basaltic clast material at specific horizons (Figs. F12, F13). Primary sedimentary layering within the unconsolidated sediment (carbonate mudstones) was distorted and largely obliterated by the arrival of the clasts. Moreover, detailed inspection of the clast margins indicates that the clasts were solidified prior to their introduction into the soft seafloor sediment. These relationships, there- 
fore, are consistent with volcanic debris having tumbled from a nearby source; a scarp-base talus, for instance.

\section{Volcaniclastic turbidites (stratigraphic Unit III, lithologic Units 8-10)}

Below the volcaniclastic debris of Unit II, a well-preserved $0.85 \mathrm{~m}$ section of finely bedded volcaniclastic material (clay to fine sandstone grain size) contains numerous small-scale fining-upward laminae (2-5 $\mathrm{mm}$ ) superimposed upon two broader fining-upward trends $(15-25 \mathrm{~cm})$. The presence of flame structures and microscours and an absence of bioturbation (with the exception of one layer) are the basis for interpreting this part of the unit as a normally graded turbidite (Section 324-U1346A-4R-2). These turbidites contain significant concentrations of materials of volcanic origin, including lithic clasts, individual crystal fragments (plagioclase), glass debris (pyroclasts), and chemically immature silt- to sand-sized particles. The small-scale fining-upward laminae themselves consist of concentrations of glassy vesicle shards, delicately preserving their intricate cuspate forms and providing evidence that transport and reworking was minimal prior to their deposition. Unlike basaltic glass, which has a brown tinge, these glass shards are virtually colorless and may be of different provenance to that of the basaltic volcanism in Units II and V. The bulk of the larger volcanic components are recognizable as small lithic fragments of highly vesicular basalt, very similar to the basalts found in Unit II. These clastic fragments are typically angular in shape and often retain their pristine vesicle structures, again indicating relatively minor particle transport or reworking. Accordingly, the volcanic source for the input in this turbidite sequence must have been co-located or else was located in close proximity. We classified Unit III as a "volcaniclastic turbidite," as the fragmental aggregate contains $>60 \%$ volcaniclastic grains (see "Igneous petrology" in the "Methods" chapter). See "Sedimentology" for a more detailed description of this unit.

\section{Shallow carbonates (stratigraphic Unit IV, lithologic Units 11-18)}

Unit IV consists of an estimated $17.1 \mathrm{~m}$ thick sediment series with clay-rich volcanogenic sandstones and siltstones, calcareous mudstones, and bioclastic limestone beds. This carbonate-rich sequence of siltand sandstone contains both authigenic glauconite and volcanogenic components. The volcanogenic component is similar in character to, but less abundant than, the volcanic debris found in the younger finer grained turbidite series of Unit III. The presence of closely packed shelly (possibly inoceramid) fragments, together with shallow-water benthic foraminifers, places strong constraints on the depth of sedimentation in Unit IV, most likely not exceeding 200 mbsl water depth. See "Sedimentology" for a more detailed description.

\section{Pillow basalts (stratigraphic Unit V, lithologic Units 19-58)}

Unit V is $50.1 \mathrm{~m}$ thick and represents the top of the volcanic basement of Shatsky Rise as drilled at Shirshov Massif. This unit is composed of a stack of lava inflation units, including basalt pillow lavas and lobes that in the core range considerably in thickness from 0.3 to $\sim 4 \mathrm{~m}$. These pillows and lobes have similar characteristics, with inner cores that are more massive, slightly coarser in grain size, and nonvesicular, with outer zones that are highly vesicular (as much as 50\%), and with rims that frequently have chilled glassy margins or pillow contact zones (Figs. F14, F15). All these inflation units are interpreted to be part of a single eruption pillow stack predominantly containing aphyric micro- to cryptocrystalline basalts. Alteration is pervasive throughout these pillows, with multiple generations of alteration almost completely filling cracks and vesicles, making these basalts strongly amygdaloidal and replacing most (if not all) of the volcanic glass (30\%-90\%), pyroxene, and olivine in these rocks. The final phase of alteration was oxidative and is the most obvious because it transforms intervals of originally dark bluish gray basalts into zones of red-brown basalt. See "Alteration and metamorphic petrology" for a more detailed description of the various alteration regimes observed in this unit.

\section{Macroscopic description}

\section{Volcaniclastic debris (stratigraphic Unit II)}

As discussed in "Igneous petrology" in the "Methods" chapter, volcaniclastic material includes a range of materials from rubbly in situ volcanic debris to resedimented materials such as volcanic sands or tuffs (see Figs. F5, F6 in the "Methods" chapter). Volcanic materials of all sizes may be the direct product of eruptive processes (pyroclastic) or may be accumulations through processes involving transport, sorting, and redeposition (epiclastic). Pyroclastic activity includes hydrovolcanic deposits formed by explosive interaction between magma and water, as well as quench fragmentation (e.g., hyaloclastite and peperite). Peperite is a distinct volcanic-sediment facies occurring where submarine basaltic lava flows interact with unconsolidated sediment as they erupt into water bodies or, more commonly, on the seafloor. The mingling of still-molten lava flows and wet sedi- 
ments produces distinct volcanic textures resulting from the physical interaction between lava and sediment (such as entrainment, baking, and chilling), as well as physical and chemical fragmentation and alteration through steam-rock interaction during flash heating of seawater. The term "peperite" is used particularly in those cases where lava-sediment mingling generated soft-sediment deformation features and when these interactions resulted in quenched margins, plastic deformation, or the in situ "jigsawfit" cracking of the volcanic clasts involved. However, because these characteristic peperite features could not readily be identified in the retrieved core and therefore require shore-based petrographic studies for confirmation, we classified the volcanic materials in Unit II simply as rubble or debris flows.

Unit II (lithologic Units 3-7 in Figs. F10, F11) is divided into five intervals in which volcaniclastic material is an important component (see Sections 4R-1 and 4R-2 in "Core 324-U1346A-4R" in "Visual core descriptions" in "Core descriptions"). Three of these five intervals (Units 3, 5, and 7) for the most part consist of light green-blue, highly vesicular basalt mixed with sparsely distributed angular fragments of sedimentary material. The other two intervals (Units 4 and 6) consist of the same materials, but they are dominated by highly disturbed greenish to light brown carbonate mudstones (Figs. F12, F13) with only a few angular clasts (all $>7 \mathrm{~cm}$ ) of greenish vesicular basalt intermixed, in a few places showing soft-sediment deformation at or near the basalt/sediment contacts (intervals 324-U1346A-4R-1, 28-32 $\mathrm{cm}$, and $75-90 \mathrm{~cm}$ ). The nature of the contact relations between these two distinct lithologies indicates that the basaltic clasts solidified prior to their introduction into the soft seafloor sediment, consistent with debris introduced from a nearby volcanic source.

The sparsely to moderately vesicular basalt has a cryptocrystalline to microcrystalline groundmass. Approximately half of the highly spherical vesicles are filled with secondary minerals (predominantly calcite), and veins within the basalts are filled with dark green clays. Chilled margins are not present in the basaltic clasts, and typically plagioclase crystals and vesicles are broken along the margins of these clasts. The clayey layers in the limestone matrix are deformed parallel to the margins of the basaltic clasts, and sediment in a few cases fills vesicles and small voids in the vesicular basalt clasts.

\section{Pillow lava and inflation pods (stratigraphic Unit V)}

Many mafic lava units develop through endogenous growth or "inflation," for example, pahoehoe, mas- sive flood basalt units, and submarine pillow lavas (Self et al., 1998). Pillow lava units (see Figs. F14, F15 for schematic drawings) are a typical product of basaltic eruption in submarine conditions (Batiza and White, 2000). Basaltic lava is internally transported within propagating flows (or within lava tubes) to active flow fronts where the lava flow advances by creating and inflating a lobe that typically has a continuous crust (Walker, 1991; Hon et al., 1994). On contact with water, these lobes chill rapidly, forming a glassy outer crust (Figs. F14, F15C, F16) that entraps gas vesicles that continue to form and grow within the remaining molten core. The surface contraction and stretching and fracturing of the solidifying outer skin provides the first places where vesicles accumulate and get trapped, leading to small radially arranged vesicle trains immediately inward of the glassy chilled pillow margin (Figs. F15C, F16). Within the still-molten core of the lava, continued cooling causes the gases to further exsolve, producing more vesicles, which move toward the surface but become frozen at the base of the solidification front that moves inward as the outer part of the pillow keeps cooling. This is the origin of the concentric zones of vesicles that are distinctive of the internal structure of many pillow lavas (Fig. F15A). Large vertical pipe vesicles as long as a couple of centimeters may form in the cores of larger pillow units (Fig. F15B) when stagnation of lava and slow cooling subsequently allow these larger vesicle trains to develop. Given sufficient time, the largest vesicles within these cores will slowly evacuate toward the upper region of the pillows, resulting in near-nonvesicular pillow cores in the larger inflation units. Distinctive crystal grain size changes can also be observed from pillow margin to core because the development of the outer (insulating) crust arrests any further rapid chilling of the lava within, allowing a coarser, sometimes wholly crystalline internal fabric to develop. Accordingly, the degree of interstitial glass diminishes markedly away from the edges of a pillow unit, increasing in crystallinity inward. During emplacement, glassy chilled zones of pillow units typically spall, accumulating in the interstices between neighboring pillow units (see lithologic Units 55 and 57 for good examples). These glassy outer layers and spalled interpillow hyaloclastites are highly susceptible to alteration and erosion, explaining their relatively poor preservation and recovery during drilling, excepting those instances where the material has been incorporated into zones of secondary cementation.

\section{Pillow inflation units}

All pillow characteristics described above were observed in basaltic basement Unit V recovered at Site 
U1346. In cases where chilled margins, glassy rinds, or pillow contacts (Fig. F15C, F16) were observed, the interval in the cored material could be confidently described as a separate pillow unit (Fig. F11). However, more commonly, the position of contacts between two pillow units had to be inferred using a combination of vesicle characteristics, changes in grain size and texture, and/or the presence of glassy material (see "Interpillow volcaniclastics" for more details). In instances where a pillow unit could not be unequivocally determined, the generic term "lava inflation unit" was used.

The largest inflation units range in diameter between 1 and $\sim 4 \mathrm{~m}$. The larger units typically contain massive nonvesicular cores with sometimes two or three isolated, centimeter-long, vertical vesicle trains. The smaller units are only $\sim 0.3-1 \mathrm{~m}$ in diameter and were typically more readily identifiable as pillow lava, especially when preserved in entirety within two or three, or even in single core pieces (Figs. F14, F15A). These smaller pillows generally have thick (10-30 $\mathrm{mm}$ ) glassy margins and vesicle patterns typical of submarine lava flows, including outward radiating and banded inward concentric vesicle distributions. Even though recovery of the external parts of pillow units (i.e., glassy rind, chilled zone, and adjacent vesicle-rich region) typically is poor, good examples were encountered in Sections 324-U1346A-8R-1, 13R-1, and 14R-1 and two excellent examples occur in Section 16R-2 (lithologic Units 52 and 56). By contrast, larger fragments or even entire sections of the massive core regions of larger inflation units are well represented in the material recovered in Sections 324-U1346A-9R-2 through 12R-2 (lithologic Units 32-37).

In instances where the outer regions of inflation units were preserved, aphanitic zones (Figs. F14, F15C, F16) were found immediately inside the glassy margins. Pillow interiors often display variolitic texture imparted by acicular plagioclase microcrysts with interstitial clinopyroxene and lesser titanomagnetite and only a modest $(0-0.25 \mathrm{~mm})$ variation from crypto- to microcrystalline texture (see groundmass grain size in Fig. F10) toward the cores of the larger pillow units.

General observation of the recovered cores indicates fundamental changes in the degree and type of alteration. The topmost Cores 324-U1346A-6R and 7R display bluish gray color derived partly from primary mineralogy and partly from the replacement of igneous minerals by dark clay-type alteration products. In Cores 324-U1346A-8R through 15R the basalts are pervasively altered to a brownish alteration color, with only the inner cores of the larger inflation units retaining the bluish gray color typical of the altera- tion in the uppermost units. In these brown oxidative alteration zones, the small pillow units and outer glassy or vesiculated zones are always altered in their entirety. The lowermost Cores 324-U1346A-15R and $16 \mathrm{R}$ are characterized by a return to bluish gray altered basalts. In Unit V differences in color therefore reflect the variation in the style of alteration through the pillow stack (for details see "Alteration and metamorphic petrology").

The most remarkable feature of these pillow units is their unusually high degree of vesicularity. Their formation is probably significantly augmented by steam, reflecting shallow-water conditions during eruption. The smallest recognizable inflation unit within the succession of Unit $\mathrm{V}$ consists of a single pod or pillow of basalt that often has upper and lower chill zones and glassy contacts. Internally these pods frequently have characteristic vesicle patterns that allow them to be distinguished from one another as well (or from broken up intervals in core when recovery is poor). Because the pervasive alteration makes it very difficult to impossible to observe any petrologic break within Unit V (see "Petrography"), we concluded that these individual lava units are themselves stacked (grouped) together into one "lava package" representing a short eruptive period of continuous build-up of lava units. As no interbedded sediment was recovered, the succession of inflation units in Hole U1346A likely represents a continuous "single eruptive event" (Chenet et al., 2009) during which successive pods or pillows were produced and stacked in a single package one upon another (Table T5).

\section{Vesicle distribution patterns}

Systematic variations in the sphericity, roundness, abundance, and size of vesicles occur from the margins to the interiors of the pillow inflation units. These types of vesicle variations (Fig. F14) are particularly well developed in Section 324-U1346A-14R-1 (lithologic Units 40 and 42). A series of distinct vesicle types and patterns have been recognized these may be summarized as follows:

- Type 1: radiating vesicle trains. At the outermost margins small $(2-10 \mathrm{~mm})$ elongated vesicle trains radiate outward, truncating at the glassy and cryptocrystalline exterior. These vesicle trains appear to be concentrated along incipient fractures produced during the initial cooling contraction of the chilled "outer skin" of the erupted magma pod (Figs. F14, F15C).

- Type 2: concentric vesicle zones. Inward of the Type 1 vesicles is a zone of high-sphericity, rounded to subrounded vesicles. These are concentrated into a series of 2 to 5 concentric bands resulting in a 
wide highly vesiculated zone, the thickness of which depends on the size of the inflation unit (Figs. F14, F15A, F15C). The concentric banding most probably records the inward progression of the solid/liquid interface during solidification of the pillow unit and generally is more intensely developed in the upper parts of the larger inflation units.

- Type 3: gas blisters. Coalescence of small (0.5-2 $\mathrm{mm}$ ) vesicles is common in the innermost part of the banded zone of Type 2 vesicles, and in some instances this coalescence results in larger (30-50 $\mathrm{mm}$ ) "blister-" type vesicles (Fig. F15A). These oversized vesicles can have an irregular and ragged internal morphology and typically form in the later stages of solidification when the remaining magma was becoming too viscous to allow significant vesicle movement.

- Type 4: pipe vesicles. Vertically and subvertically oriented trains of (subrounded) elongate vesicles occur in the core regions of some larger inflation units (Fig. F15B). These vesicles record the stagnation of the magma during its cooling and solidification once the unit was emplaced.

The remainder of the core is typically nonvesicular or else contains only a sparsely uniform distribution of very small microvesicles $(<0.2 \mathrm{~mm})$.

\section{Interpillow volcaniclastics}

In the pillow stack of Unit V some highly altered intervals of carbonate-cemented fragmentary volcanogenic material occur. In the drill core these were typically recovered as individual isolated pieces, but they invariably occurred at the junction between two or more successive inflation units. These are interpreted as pockets of glass-shard material that accumulated in the interstices of the newly formed lava stack as the result of surface spallation from nascent pillow units. Accumulations and pockets of these kinds of materials are also reported in onshore studies of LIPs containing similar stacks of pillow lavas, as for instance preserved in accreted terrains (Greene et al., 2010). In Hole U1346A profound recrystallization makes determination of the morphology and size of the fragments difficult, but the larger volcaniclastic fragments appear to be $3-5 \mathrm{~cm}$ in length. As seawater and hydrothermal fluids have passed pervasively through the volcanic basement at this site, in particular using the interpillow spaces as conduits, much of these void spaces now is occupied by calcite cement. Good examples of this interpillow volcaniclastic material occur in Sections 324-U1346A-14R-1 (lithologic Units 31 and 44) and 8R-1 (lithologic Unit 30).

\section{Petrography}

Coring in Hole U1346A penetrated $>52$ m of volcanic rock, most of it in a sequence of particularly vesicular and strongly altered pillow lava units. The primary vesicularity elevated the porosity of the rock and contributed to its ease of fracturing, allowing seawater and hydrothermal fluids to penetrate and pervasively alter the volcanic basement. As a result, the basement rocks are strongly overprinted by the effects of these fluids. Patterns of alteration are readily apparent in the strongly contrasting green, brown, and (ostensibly fresher) gray coloration of the rock (see "Alteration and metamorphic petrology").

This pervasive attenuation prevents a full and clear description of the primary igneous petrography and mineralogy of the basalt, at least for the present. Most of the rock consists of $60 \%-80 \%$ secondary minerals, dominated by clays, Fe oxyhydroxides, calcite, and pyrite. Calcite alone is so pervasive a replacement mineral that judging the original extent of occurrence of olivine and even clinopyroxene from thin sections is difficult in many of the pillow basalt specimens in Unit V. Distinctions between aphyric rocks and those containing (remnants of) microphenocrysts therefore cannot easily be made. Even secondary calcite in the veins and vesicles of some portions of the core has been substantially recrystallized and stained brown with Fe oxyhydroxides in a later alteration phase.

Most of the rocks appear aphyric because no phenocrysts can be readily discerned in hand specimens. However, attention to the chilled margins of pillows gives the impression that they originally contained small $(<1 \mathrm{~mm})$ euhedral microphenocrysts of plagioclase and olivine. Nevertheless, some of the rocks are porphyritic because they contain a few larger phenocrysts $(>1 \mathrm{~mm})$ or glomerocrysts (of mostly plagioclase), as shown in Table T6. Groundmass textures reveal no obvious differences in the size and crystal morphologies of marginal spherulites or acicular pillow interiors, which might suggest that chemical differences occur within the pillow sequence of Unit V. However, the volcanic clasts found in the shallow sediment of Unit II may represent a slightly different composition since they are more strongly plagioclase-phyric when compared to the pillow basalts from Unit V.

Glassy rinds are present on a number of the smaller pillow units, although they are typically completely altered. In rare instances, where glass is preserved in small amounts, it offers a starting point for developing a crystallization history for these basalts. For instance, fresh glass was found in two small fragments, 
each $\sim 0.5 \mathrm{~cm}$ wide in a pillow chilled margin in Thin Section 28 (Sample 324-U1346A-9R-1, 56-60 cm) (Fig. F17). In this thin section, the fresh glass is partly surrounded by an orange palagonite rim and contains tiny crystals of plagioclase with branching or dendritic morphologies and long slender needles of larger plagioclase crystals. Adjacent to one glass fragment, an altered olivine microphenocryst containing small, dark brown Cr spinel is partly intergrown with, and also plated by, small acicular plagioclases. Although no other glass was found in the 60 thin sections studied, spherulitic margins elsewhere in the core appear to have the same mineralogy and crystal morphologies. The rocks in general, therefore, may be described as a very sparsely microphyric olivine-plagioclase basalt with accessory spinel.

\section{Volcaniclastic debris (stratigraphic Unit II)}

The basaltic clasts of Unit II are generally sparsely to moderately plagioclase phyric (as much as $\sim 5 \%$ ). All basaltic clasts are vesicular (5\%-20\% of vesicles) with the vesicles completely filled by secondary minerals, dominated by calcite (see "Alteration and metamorphic petrology"). Plagioclase phenocrysts and microphenocrysts $(0.5-1.2 \mathrm{~mm})$ in this unit are typically subhedral to euhedral (Figs. F18, F19, F20). Groundmass microlites range from microcrystalline $(0.1-0.2 \mathrm{~mm})$ to cryptocrystalline $(<0.1 \mathrm{~mm})$, exhibit spherulitic and intersertal textures (Fig. F20), and consist of plagioclase ( 20\%) that typically is subhedral to euhedral and acicular (Fig. F19). Opaque minerals are minor $(2 \%-7 \%)$.

\section{Pillow lava and inflation pods (stratigraphic Unit V)}

Since the rocks are pillow lavas, considerable variation in cooling rate and crystallization occurred between pillow rim and pillow interior. Thin section examination confirms that traverses from the pillow margin to interior show textural gradations from glassy pillow rims to a microcrystalline margin and an innermost very fine grained crystalline interior. Degrees of alteration depend strongly on proximity to veins and sometimes vesicles (see "Alteration and metamorphic petrology"). All pillow basalts show some level of vesicularity, ranging from sparsely vesicular in core regions to highly vesicular at the outer margins ( 50\%).

The pillow basalts of Unit V are aphyric (Fig. F18), but they also show sporadic traces of completely altered olivine microphenocrysts $(0.1-0.4 \mathrm{~mm})$ pseudomorphed to calcite (Fig. F21). Clinopyroxene has been altered to a similar degree, whereas plagioclase is significantly less affected. It seems that in the majority of cases that clinopyroxene is likely to have constituted a significant proportion of the groundmass mineralogy. However, these minerals now are virtually completely replaced by calcite, and only traces of strongly altered titanomagnetite can be seen in either transmitted or reflected light. In some instances large clinopyroxene crystals $(0.2-1.0 \mathrm{~mm})$ are still somewhat intact and subophitically enclose plagioclase (Fig. F22), which, from the pillow margin inward, transition into dense networks of interlocking acicular plagioclase (Fig. F20A-F20C). These tabular plagioclase microcrystals also may plate the margins of pseudomorphed olivine that often contains small brown $\mathrm{Cr}$ spinel and melt inclusions (Figs. F20D, F23).

Groundmass in pillow rims is typically glassy or cryptocrystalline $(<0.1 \mathrm{~mm})$ and shows spherulitic or hyalophitic texture. On the other hand, groundmass in pillow interiors is microcrystalline $(0.1-0.2 \mathrm{~mm})$ or very fine grained $(0.2-0.5 \mathrm{~mm})$ and typically exhibits spherulitic and intersertal texture (Fig. F19). Plagioclase microlites are the most common and typically subhedral to euhedral, often in a markedly acicular texture (Fig. F20). Although plagioclase is the least altered mineral in these pillow basalts, alteration is often significant and has in particular attacked the cores of these crystals (Fig. F19). Olivine microphenocrysts are euhedral to subhedral (Fig. F21) and completely altered to calcite. Spinels are observed in the cores of altered olivine pseudomorphs (Fig. F21), and sometimes remnants of previous melt inclusions are observed in these pseudomorphs (Fig. F23). Clinopyroxene microlites and microphenocrysts are anhedral to subhedral, but often the clinopyroxene has grown in fibers (Figs. F20E, F22E, F22F). Because of the almost complete alteration to calcite, the modal abundance of both olivine and clinopyroxene are not easily estimated; nevertheless, their relative abundance is summarized in Table T6.

\section{Phenocrysts}

Basalts of Unit V are considered to be of a single petrographic type, carrying microphenocrysts of olivine and spinel, plus microphenocrysts of plagioclase and, where it has not been obliterated by alteration, clinopyroxene. Table T6 categorizes the occurrence (as not present, rare, present, or abundant) and distribution in all thin sections of phenocrysts and microphenocrysts of olivine, plagioclase, and clinopyroxene. Rocks that visually are discerned as aphyric may in thin section contain microphenocrysts. Microphenocrysts are crystals that are $<1 \mathrm{~mm}$ in length and tabular to euhedral and faceted in outline, and thus were present in the molten basalt upon erup- 
tion. Cr spinel is a consistent accessory mineral that is typically enclosed in olivine phenocryst hosts but is so tiny that it cannot be observed in hand specimens. Under the microscope it is usually engulfed in groundmass crystallization. Nevertheless, if Cr spinel is present in olivine with clear crystal outlines, it must have been present in the melt upon eruption as well. In Table T6, spinel is simply noted when it is present or absent.

Olivine: Examples of olivine phenocrysts are shown in Figure F21. All examples are from the pillow stack sequence of Unit V. Each olivine crystal is entirely replaced by calcite, but in even the most delicate features of the original crystals, including enclosed $\mathrm{Cr}$ spinel, outlines of melt inclusions, fracture patterns, and delicate dendritic extensions are preserved. The largest olivine phenocryst in all the thin sections is still only $\sim 1.5 \mathrm{~mm}$ in longest dimension; all others are on the order of $0.1-0.2 \mathrm{~mm}$. Tiny circular melt inclusions, now crystallized to clay minerals and invariably encased in calcite, are quite common (Fig. F23).

Plagioclase: Some fairly large plagioclase phenocrysts and glomerocrysts occur in the basalt clasts of the volcanic breccia of Unit II (Fig. F22A, F22B). Most thin sections of the pillow sequence of Unit $\mathrm{V}$ are devoid of even the smallest plagioclase microphenocrysts. Only one microphenocryst was found in a sample from near a pillow rim.

Clinopyroxene: In most thin sections, acicular plagioclase is not intergrown with clinopyroxene. This is true even in samples where the plagioclase forms an interconnected network (Fig. F19). Existence of such clinopyroxene, however, is difficult to judge in samples where calcite has replaced most interstitial material between the plagioclase crystals. A few samples are sufficiently fresh and coarse grained to preserve intergrowths of needlelike plagioclase and irregularly shaped but often bladed clinopyroxene showing patterns of dendritic crystal growth (Fig. F22). Only one sample contains fresh clinopyroxene microphenocrysts (Table T6), but even these crystals seem to consist of coalesced bladelike domains that are intergrown with acicular plagioclase needles (Fig. F22E, F22F).

Spinel: Spinel most commonly occurs as tiny $(\sim 5-10$ $\mu \mathrm{m})$ isolated cubic or octahedral crystals within altered olivine microphenocrysts (Fig. F24A, F24E, F24F). The small crystals are dark brown in transmitted light (Fig. F24B), quite often occur in clusters or clumps (Fig. F24A, F24C), and are strongly reflective and never altered, despite complete replacement of adjacent olivine by calcite. Usually these crystals occur singly or in small numbers within individual olivine crystals (Fig. F24D). Only one larger semi-pyra- midal crystal of spinel (Fig. F24F) occurs in all of the thin sections examined. The presence of spinel proved to be the key to recognizing many associated olivine crystals otherwise completely pseudomorphed by calcite.

\section{Segregation vesicles}

Perhaps the most striking physical feature of the basalts, especially in the pillow lava stack of Unit V, is their vesicularity. Some rocks have as much as 50\% vesicles that are now amygdules filled with calcite and other secondary minerals. Whereas vesicularity clearly indicates shallow eruption, it remains to be determined whether the magmas themselves were sufficiently rich in volatiles to produce so many large vesicles or whether the erupting pillows partially ingested seawater to form steam.

In the more coarsely crystalline pillow interiors we also find segregation vesicles. These occur when adjacent molten material develops crystals, particularly sharply pointed acicular plagioclase, which can puncture the walls of the vesicles. This allows a little bit of interstitial melt to leak (segregate) into the vesicle voids as the rock cools and gas within the vesicle contracts. Figure F25A shows a vesicle within an outer spherulitic portion of a pillow margin that simply was quenched and not yet punctured. The vesicle walls are now lined with brown clays. Another small vesicle shown in Figure F25B was found further into a pillow interior, showing that its walls first were punctured by acicular plagioclase needles and then partially filled with melt introduced through the severed walls. The introduced melt often forms a curving meniscus within the vesicle, against which the shrinking volume of gas typically forms a boundary. Later, alteration minerals were introduced and formed the orange clays and other fine-grained crystalline materials in this vesicle.

Since the injected melt originally was interstitial between the crystals of the surrounding rock, it is more differentiated than the bulk composition of these pillow lavas. In the case of basaltic magma crystallizing mainly plagioclase, this means that the segregate melts are richer in $\mathrm{TiO}_{2}$ and total iron $\left(\mathrm{Fe}_{2} \mathrm{O}_{3}{ }^{\mathrm{T}}\right)$. The result is that the vesicle menisci comprise intergrowths of dendritic clinopyroxene with consistent extinction directions over several adjacent elongate needles of the mineral (Fig. F25C, F25D). Tiny skeletal titanomagnetite occurs between the pyroxene dendrites (Fig. F25E). These are about the only places where titanomagnetite can be seen even (in reflected light) in the otherwise strongly altered rock.

Some vesicles are very large $(0.5 \mathrm{~cm}$ to several centimeters wide) and thus can contain very large segregation menisci. The injected melt clearly continued 
to vesiculate even in the segregation vesicles (Fig. F25F). In this case, these second-generation vesicles are now lined with green clay, and the larger, original vesicle space, sequentially, was lined with clear clay, green clay and calcite.

\section{Assessment}

A variety of features indicate a petrographic (and thus likely compositional) uniformity of the pillow sequence of Unit $\mathrm{V}$. These are

1. Persistence of small olivine microphenocrysts and occluded tiny Cr spinel;

2. Rarity or absence of plagioclase microphenocrysts;

3. Presence of acicular plagioclase in the groundmass of almost all samples examined, forming interlocking crystalline networks in coarser grained rocks; and

4. A high degree of vesicularity.

The original work of Miyashiro et al. (1969) recognized two principal types of basalt from the Mid-Atlantic Ridge, namely aphyric and strongly plagioclase-phyric variants of what we now recognize as mid-ocean-ridge basalt (MORB). Spinel occurs in these rocks, whereby the plagioclase-phyric MORB variant often has a few olivine phenocrysts, dark brown Cr spinel, and at times phenocrysts of clinopyroxene (Natland et al., 1983). When the pillow sequence of Unit $\mathrm{V}$ is taken in conjunction with the plagioclase-phyric basalts of Unit II, the rocks of Hole U1346A have some resemblance to both types of basalt recognized by Miyashiro et al. (1969). In addition, the basalts seem to be less differentiated (based on the absence of clinopyroxene in the mineralogy) than those of Site 1213 from the southern extremity of Shatsky Rise. Other comparisons to MORB and the other Shatsky Rise basalts may arise from geochemistry, but unless immobile elements and element ratios are employed, the original igneous geochemical stratigraphy may be difficult to obtain because of the far-reaching alteration.

\section{Conclusions}

Coring in Hole U1346A penetrated $>52 \mathrm{~m}$ of volcanic rock, most of it a seemingly continuous sequence of particularly vesicular and strongly altered pillow lava and larger inflation units. The volcaniclastic material encountered in Unit II is interpreted as solidified volcanogenic debris introduced onto a shallow marine substrate (less than $\sim 200 \mathrm{~m}$ deep) consisting of mainly unconsolidated mud. The softsediment deformation around these large volcanic clasts indicates that the material fell into the sediment, possibly rolling downslope from a higher eruption source. Unit II also appears to intervene between the formation of a volcanic stack of pillow lavas (Unit V) and the onset of sedimentation in a progressively deepening water column (Units IV, III, and I). Within that context Unit II may instead include volcanogenic fragments displaced from an existing volcanic edifice (i.e., a talus or debris flow) following cessation of volcanism. The presence of volcanogenic sand and turbidites described in Unit III further supports this interpretation. The delicate cuspate glass shards within the fining-upward lamellae of this unit may, however, have a different origin. Their preservation precludes significant transportation by ocean floor turbidity currents. They therefore may represent subaerial ash fall material that has settled through the water column, or else these glass shards are derived from a contemporaneous hyaloclastite source (e.g., an erupting submarine vent) located nearby. Similar clouds of vesiculated submarine glass debris have been observed settling on the seabed near ongoing phreatomagmatic activity supplied from Pu'u O'o on Hawaii (Umino et al., 2006). Curiously, the pale to colorless character of the glass shards is inconsistent with a mafic source, requiring further analysis to determine the composition of these glass fragments and their origin.

The actual volcanic basement of Shatsky Rise at the Shirshov Massif consists of a stack of highly vesicular basaltic pillow or inflation units grouped into Unit V. Individual pillows were readily identified by the presence of chilled glassy margins, upper and lower chill zones, characteristic pillow vesicle patterns, and crystal grain size variations. In total, 40 of these individual inflation units were recognized (and reported in this site report as lithologic Units 19-58). Downhole logging results indicate levels at which the volcanic stack is less dense, and may be more susceptible to fragmentation, in particular as these are often correlated with intervals of poor recovery. A plausible explanation is that the lava units are smaller, more vesicular, or more strongly altered in these intervals. However, the absence of any intercalated sedimentary material in the cores within Unit V suggests that the succession exists of a near-continuous build up of lava lobes at this particular location and thus likely represents a single lava package or even an eruptive event of pillow basalt (Table T5).

Based on information from sediments cored just above the lava, the volcanic rocks of Units II and V erupted in water certainly no deeper than a few hundred meters (and possibly even shallower). Assuming that the primary water content of Shirshov Massif magma was similar to MORB and Ontong Java Plateau (OJP) magmas (0-0.5 $\mathrm{wt} \%)$, we estimated that the volatilization depth must have been $<300 \mathrm{~m}$ 
(Newman and Lowenstern, 2002). This is an important factor that no doubt contributed to the relatively high vesicularity in the lavas of Units II and V. The close association with carbonate-rich sediment also may have controlled the high percentage of calcite lining fractures and calcite filling the myriad of vesicles in the rock. The vesicularity in turn elevated the porosity of the rock and its ease of fracturing, which almost certainly contributed to the ability of seawater and hydrothermal fluids to penetrate the rock and alter it. Finally, the drilled sequence of igneous rock also must have been close to a low-temperature discharging hydrothermal vent, similar to those found near submarine hot springs on mid-ocean spreading ridges. As a result, the volcanic basement rocks of Units II and V are strongly overprinted by the effects of meandering fluids, and patterns of alteration are readily apparent in the strongly contrasting green, brown, and (ostensibly fresher) gray rock in the core.

\section{Alteration and metamorphic petrology}

The entire section of basaltic basement recovered from Hole U1346A has undergone low-temperature water-rock interactions resulting in near-complete replacement of pyroxene, olivine, and glassy pillow rinds and complete replacement of glassy mesostasis. In contrast, plagioclase is generally well preserved. The overall alteration of the basalt pieces ranges from $25 \%$ to $90 \%$, estimated visually using the binocular microscope on the archive half and the optical microscope on discrete thin section samples, without taking into account veins and vein halos.

Clay minerals are the most abundant secondary minerals and were principally identified by optical microscopy and X-ray diffraction (XRD) patterns on whole-rock, vesicle, and vein samples. Identification of clay species on XRD patterns is difficult because of the high proportion of calcite in the samples. Nontronite is the most readily identifiable clay mineral in the sequence with a green color and pleochroism in transmitted light. Saponite is identifiable by its translucent brown color in transmitted light and its third-order birefringence in cross-polarized light. Calcite is the second most abundant secondary mineral in these basaltic rocks, both pervasively altering the rocks and filling vesicles, voids, and veins. XRD spectra of whole rock, vesicles, and veins suggest that calcite is dominantly magnesium calcite. Other alteration minerals identified in the cores include pyrite, Fe oxyhydroxides, very rare marcasite and chalcopyrite, and zeolite only in one sample.
We compared the alteration degree and mineralogy of basaltic rocks recovered from Hole U1346A with previously well studied portions of ocean crust (Alt, 1995,2004 ) and with basalts recovered from the Ontong Java Plateau (ODP Leg 192) (Mahoney, Fitton, Wallace, et al., 2001; Banerjee et al., 2004), Deep Sea Drilling Project (DSDP) Site 454 in the Mariana Trough (Natland and Hekinian, 1982), and DSDP Site 543 in Cretaceous crust of the Mid-Atlantic Ridge, near the Barbados accretionary prism in the western North Atlantic (Natland et al., 1984).

\section{Low-temperature pervasive alteration processes}

Based on core descriptions and thin section observations, we identified three types of pervasive alteration and two principal types of veining. Alteration colors range from dark gray to brown, with green alteration recovered at the top of the hole. The distribution of alteration colors is given in Figure F26 and in 324ALT.XLS in LOGS in "Supplementary material." Color classification was made on wet cut surfaces of the archive section half.

\section{Green alteration}

Extensive green alteration was only encountered in the first two igneous sections recovered $18 \mathrm{~m}$ above the onset of continuous igneous lithology interpreted as basement contact in Hole U1346A (from Section 324-U1346A-4R-1, $0 \mathrm{~cm}$, through 4R-2, 39 $\mathrm{cm} ; 119.5-121 \mathrm{mbsf})$. This sequence, defined as volcaniclastic debris by the igneous petrologists (stratigraphic Unit II), contains vesicular basaltic clasts interspersed with carbonate sediments. The basaltic clasts show a high degree of alteration ranging from $80 \%$ to $95 \%$. Plagioclase is the only primary igneous phase remaining, although it has been moderately altered to brown clay. By contrast, pyroxene and glassy mesostasis are completely altered to green and brown clays, including nontronite and pyrite. Vesicles are rimmed by dark clays overlain by nontronite and are infilled with calcite, pyrite, and very rare marcasite and chalcopyrite (Fig. F27).

\section{Dark gray alteration}

Dark gray alteration is the most common alteration type encountered in the basement basalts in Hole U1346A (Fig. F26). Overall alteration of these variably vesicular basalts ranges from $30 \%$ to $70 \%$, based on petrographic observations of thin sections. Secondary minerals in gray to dark gray basalts are brown clay minerals, which are typically very fine grained and difficult to identify either by optical microscopy or in XRD patterns. During this expedition, 
groundmass clays rarely have been identified as a fibrous brown saponite. Brown clays completely replace the glassy mesostasis, and pyroxenes are nearly completely replaced by calcite. Relics of primary pyroxenes are observed in some samples (e.g., Sample 324-U1346A-7R-1, 52-54 cm) (Fig. F28). The presence of olivine is inferred from the observation of calcite pseudomorphs that commonly contain fresh spinel (Sample 324-U1346A-8R-1, 56-60 cm). Calcite is also present as a minor phase throughout the claydominated altered groundmass.

\section{Brown alteration}

Brown alteration is found in short intervals alternating with the dark gray basalts (Fig. F26). The brown alteration overprints the gray alteration and many of the veins (Fig. F29). Overall alteration of these brown, variably vesicular basalts ranges from $30 \%$ to $60 \%$, based on petrographic observations of thin sections. Secondary minerals in these brown basalts are brown clay minerals completely replacing the glassy mesostasis and almost completely replacing the pyroxenes, whereas plagioclase is moderately affected by alteration. Calcite pseudomorphs after olivine are also present in these basalts. Fine-grained Fe oxyhydroxides are disseminated in the groundmass and together with the brown clays likely give the rocks their brown color.

\section{Glass alteration}

Alteration of glass to phyllosilicates is virtually complete throughout the entire hole. No glassy mesostasis in the interiors of pillows and no pillow rim glass on the external rind of the pillows were preserved. Glass shards in hyaloclastites were nearly completely altered to phyllosilicates. Small segments of basaltic glass were only observed in two places in the core: in brown altered basalt in Sample 324-U1346A-8R-1, $56-60 \mathrm{~cm}$, and in gray altered basalt in Sample 14R$1,122-124 \mathrm{~cm}$. In both cases glass is present as shards in hyaloclastites, which were preserved in a calcite cement (Fig. F17).

\section{Vesicles}

Basaltic rocks recovered from Hole U1346A are virtually all highly vesicular. The vesicles are filled with calcite and clays, irrespective of the alteration type, and commonly show a rim of dark brown clay minerals and fine-grained oxides, interpreted to be altered segregation melt within the vesicles (Fig. F30). Open vesicles or vesicles partially filled with clays are rare and only observed in fine-grained pillow rims. Pyrite is a major component, associated with little or no Fe oxyhydroxides, of the vesicle fillings in Unit II (Fig. F27) and in the upper part of the basement suc- cession (above 143 mbsf in Cores 324-U1346A-6R and 7R). Below this depth, Fe oxyhydroxides are occasionally found in the vesicles in the gray alteration zones. Rarely, vesicles contain fibrous clays including nontronite and saponite (e.g., Sample 324-U1346A13R-1, 102-105 cm) (Fig. F31).

\section{Vein fillings}

Eleven veins were counted in the green altered basaltic volcaniclastic debris (Unit II) and 159 veins in the $\sim 53 \mathrm{~m}$ of basement rocks recovered from Hole U1346A (see Fig. F32 and 324VEIN.XLS in LOGS in "Supplementary material"), making an average of 3 veins $/ \mathrm{m}$. Veins in Unit II are isolated within the vesicular basalt and do not appear to extend into the enclosing sediment. Nevertheless, the mineralogy of the Unit II veins is nearly identical to that in the basement pillow lavas. All veins will therefore be considered together in the following description.

Most of the veins result from symmetrical infilling of open cracks with minor or no replacement of the wall rock. Two main vein types occur: (1) massive calcite veins and (2) nontronite-bearing veins associated with calcite, with or without either Fe oxyhydroxides or pyrite. Cross-cutting relationships, shown in Thin Section 51 (Sample 324-U1346A-14R$2,66-70 \mathrm{~cm}$ ) (Fig. F29), indicate that calcite veins are later than nontronite-bearing veins. In the nontronite-bearing veins, nontronite typically occurs along the rims and the interior of the veins is cemented with calcite, indicating that nontronite precipitated before calcite.

Pyrite occurs only as a major phase in the veins in the upper portion of the succession (Figs. F32, F33) with little or no Fe oxyhydroxides, whereas below 142 mbsf veins contain significant Fe oxyhydroxides (Fig. F34) in both brown and gray alteration styles. The veins range from fine fractures $<0.5 \mathrm{~mm}$ to zoned veins of up to $3 \mathrm{~cm}$ in width, and vein width shows no systematic variation with depth (Fig. F32).

\section{Sulfides}

The volcaniclastic debris (Unit II; Core 324-U1346A$4 \mathrm{R}$ ), recovered on top of $\sim 60 \mathrm{~m}$ of sediment and extensively altered to green clays, are the only rocks in Hole U1346A to carry abundant pyrite and other sulfide minerals. Several percent of sulfides are present in the green basalt clasts in Core 324-U1346A-4R, which are set in indurated limestone that still shows sedimentary deformation around the clasts. Sulfides diminish in abundance in Core 324-U1346A-6R, are present but sparse in rocks at the top of Core $7 \mathrm{R}$, and do not occur between Thin Section 22 (Sample 7R-2, 91-102 cm) and Core 11R. They are then minor 
through Core $14 \mathrm{R}$ and absent thereafter to the base of the hole.

Figure F27 shows features of the sulfides as seen in reflected light. In Thin Section 6 (Sample 324U1346A-4R-1, 48-51 cm), sulfides are concentrated mainly in calcite veins and calcite-filled vesicles. The principal sulfide is pyrite, which occurs both in blocky and porous forms (Fig. F27A). Two small crystals of chalcopyrite (darker bronze) are also present. In Figure F27B, the blocky sulfide is marcasite (different colors in partially cross-polarized light and also anisotropic when rotating the stage) and the porous sulfide again is pyrite. Figure F27C shows a small vesicle in combined transmitted and reflected light. Green nontronite lines the vesicle and occurs as stringers within it. Both calcite and pyrite fill the remainder of the vesicle and are distributed across it. Other vesicles contain swarms of small pyrite crystals concentrated in calcite but to one side of the amygdule (Fig. F27D). An interpretation is that green clays and three different sulfides formed first and that all were cemented together by calcite in the veins and vesicles.

In some places, where calcite veins directly abut the basalt, the two forms of sulfide penetrate and replace materials between acicular plagioclase (Fig. F27E). Penetration of sulfide into basalt in this manner also occurs at the top of the pillow sequence in Core 324U1346A-6R (Fig. F27F). Only small amounts of pyrite are disseminated in the groundmass of rocks at the top of Core 324-U1346A-7R, and none exists below section 324-U1346A-7R-2.

\section{Interpretations of alteration}

The basaltic rocks recovered in Hole U1346A are all moderately to highly altered with different types of alteration, green, dark gray, and brown, reflecting chemically variable fluid flow through the different stratigraphic units. The predominance of clay minerals (nontronite and saponite), with no high-temperature alteration minerals (e.g., chlorite), suggests relatively low temperature alteration $\left(<100^{\circ} \mathrm{C}\right)$ (Alt, 1995).

\section{Green alteration: interaction with S-rich low- temperature hydrothermal fluids at the basalt/ sediment interface}

Green alteration of the basaltic rocks recovered from the top of Hole U1346A relates to extensive replacement of primary minerals to green clays (i.e., nontronite) and precipitation of calcite and sulfide minerals. Altering fluids likely entered the rock along microfractures and other microscopic porosity structures. These fluids caused the replacement of existing glass and primary minerals in the groundmass to green clays, as well as the precipitation of calcite and sulfides in vesicles. Fluid circulation in larger fractures formed veins of green clays associated with abundant reddish Fe oxyhydroxides and calcite.

Evidence for in situ alteration of volcanic rock in sediment is provided by a strikingly zoned altered clast in Thin Section 7 (Sample 324-U1346A-4R-2, 33-39 $\mathrm{cm}$ ). A greenish alteration rind surrounds a darker gray interior with two abrupt alteration fronts, the outer one $\sim 1 \mathrm{~cm}$ into the rock and the inner one $\sim 4 \mathrm{~cm}$ into the rock. The rock was cold when it combined with the enclosed indurated limestone, likely as either talus or as part of a debris flow, and it was subsequently heated and altered by circulating sulfide-precipitating hydrothermal fluids.

It is possible to correlate the green alteration of Core 324-U1346A-4R (Unit II) with the gray alteration in the basement pillow lavas of Core 6R (Unit V), sulfide mineralization being characteristic of the most pervasively altered green rocks at the basalt/sediment interface. Occurrence of three sulfides (pyrite, chalcopyrite, and marcasite) and green clays in the most pervasively altered rocks, with these changing downward to a combination of Fe oxyhydroxides and green clay, is reminiscent of mineral assemblages observed at margins of hydrothermal mounds at the Galapagos Spreading Center and elsewhere (e.g., Borella et al., 1983). The zonation suggests that nonoxidative hydrothermal fluid flow was concentrated at the basalt/sediment interface, probably related to impermeability of the sediments, and allowed precipitation of sulfides and green clays. In the porosity structure of the rocks, the fluids mixed with ambient seawater, which diluted and oxygenated them, favoring precipitation of a more oxidative secondary mineral assemblage (e.g., Fe oxyhydroxides).

Similar downward zonations in authigenic mineral paragenesis, with sulfide mineralization concentrated at the basalt/sediment interface and transitions from basalt colored green to basalt colored brown or reddish brown occur in pillow lavas drilled beneath a thin volcaniclastic blanket at DSDP Site 456 in the Mariana Trough (Natland and Hekinian, 1982) and at Site 543 in Cretaceous crust of the MidAtlantic Ridge near the Barbados accretionary prism in the western North Atlantic (Natland et al., 1984). At both places, sediment clearly provided permeability barriers through which circulating fluids in the more porous basalts could not penetrate. The sediments thus directed fluid flow horizontally, at the very top of basement.

At this juncture, temperatures of the mineralizing fluids are difficult to estimate. Both the sulfide min- 
eral assemblage and the pervasive green alteration of the basalts of Core 324-U1346A-4R suggest that fluids were warmer, perhaps by tens of degrees in the volcanic rocks that were enclosed into sediment, than they were only $60 \mathrm{~m}$ deeper in the basement pillow lavas (Unit V) from Core 6R downward. By comparison, uppermost basalt at Site 456 is chloritized and secondary mineral assemblages in recrystallized sediment suggest a temperature $>200^{\circ} \mathrm{C}$. The sequence at Site 543, on the other hand, produced the greenish magnesian clay mineral saponite together with pyrite in the most altered basalts and occurred at much lower temperature. Further study of authigenic minerals in both the sedimentary rock and basalt of Core 324-U1346A-4R is warranted. Indications of low-temperature alteration in the bulk of the pillow sequence of Unit $\mathrm{V}$ do not indicate whether a very sharp hydrothermal temperature gradient once existed over only a few meters of core at Site U1346.

\section{Gray and brown alteration: interaction with $\mathrm{CO}_{2}$-rich low-temperature fluids}

Gray alteration is the most abundant alteration type in the basement pillow lavas (Unit V) in Hole U1346A and is interspersed with brown alteration throughout the hole. Secondary mineralogy for both alteration types is dominantly clay minerals (i.e., nontronite and saponite, an Fe-Al-rich and Mg-rich clay, respectively) and calcite. Clay minerals to various extents replace glassy mesostasis, plagioclase, and pyroxene, whereas calcite only replaces pyroxene and olivine, when present. Saponite and calcite associated with pyrite are commonly observed in the ocean crust, as filling veins and cracks or replacing the groundmass and olivine, and reflect low-temperature anoxic conditions at relatively low water-rock ratios (see Honnorez, 2003, for a review). Dark gray alteration with similar secondary mineralogy has also been observed in basalts from the OJP (Banerjee et al., 2004). The particularity of alteration in Hole U1346A, compared to other portions of ocean crust and to basalts at OJP, is the extensive replacement of pyroxene and glassy mesostasis by calcite, suggesting interaction of the basalts with $\mathrm{CO}_{2}$-rich seawater-derived fluids at relatively low temperature $\left(<70^{\circ} \mathrm{C}\right)$ (Honnorez, 2003).

Brown alteration occurs in short intervals throughout Hole U1346A; petrographic observations indicate that this alteration overprinted the dark gray alteration (Fig. F29), with the secondary mineralogy being very similar to that of the dark gray alteration. Occurrences of disseminated Fe oxyhydroxides in the groundmass suggest circulation and interaction of the basalts with oxidative seawater-derived fluid at low temperature $\left(<70^{\circ} \mathrm{C}\right)$. The low magnetic susceptibility in the basalts affected by brown alteration relative to the gray alteration (see "Physical properties") likely reflects the oxidation of magnetite in the gray alteration to Fe oxyhydroxides in the brown alteration. Chemical analyses on these two types of alteration indicate that there is no clear variation in chemistry related to the alteration type (see "Geochemistry").

\section{Structural geology}

Cores recovered from Hole U1346A between 119.72 mbsf (Core 324-U1346A-4R) and 189.1 mbsf (Core 16R) contain structures of magmatic, alteration, and deformational origins. Structures described here are wholly brittle and are solely within the basalt complex. The main structural features are represented by amygdules (or vesicles), veins, vein networks, fractures, microfaults, and breccia. Igneous structures include syn- to late-magmatic structures that are linked to flow, cooling, and solidification of lava.

In the following sections, the characteristics of the structures are described followed by a discussion of the distribution and orientations of and relationships between structures and a short summary. Important observations and interpretations include

1. Preferred orientations and contact relations of planar and subplanar structures;

2. Variation in structural morphology: pattern, size, shape (roundness or sphericity), and vesicles (vesicularity); and

3. Crosscutting relationships: primary and secondary structures and structural sequence.

These are evidence for close linkages between intrusive processes, fluid flow, and brittle deformation.

\section{Magmatic flow structures}

Magmatic flow structures preserved in volcanic lavas exhibit evidence of particle rotation or plastic strain imposed by the flow of viscous magma and provide clues to movement plane and facing (Davis, 1984; Passchier and Trouw, 1996). Magmatic flow structures are only observed in interval 324-U1346A8R-1 (Piece 2D, 43-72 cm) as flow banding in chilled margins, showing oriented elongate calcite filling parallel to the chilled margins (Fig. F16). The voids that are filled by calcite are probably oriented to the direction of pillow flow.

In addition, vesicles are the frozen records of gas bubbles in lava and therefore beneficial for use in analyzing magmatic flow kinematics. That is to say, the pattern of degassing and features of the vesicles that remain in a lava flow can yield important 
information on flow mechanisms and lava rheology (Walker, 1993). In Hole U1346A, filled vesicles, also called amygdules, are very common.

\section{Chilled margins and pillow structure}

Numerous chilled margins were recovered from pillow lavas and are increasingly common with depth. Chilled margins range from lobate and interfingered to sharp. Chilled margins also contain flow banding, stretched spherulites, and injections of basalt. A chilled margin is strong evidence, one of the major identifiers, of pillow structures, which are identified by many integrated indicators including spheroidal or ellipsoidal shape, radially aligned vesicles, concentric vesicular zones, radial cracking, inner glassy skin, and flow banding (Thorpe and Brown, 1985). Several typical chilled margins are observed in Hole U1346A (Fig. F35). They differ in shape and texture from the halos of some veins in intervals 324-U1346A-14R-2, 64-82 cm, and 14R-3, 21-40 cm (Fig. F36). The true dip of the chilled margins ranges from $30^{\circ}$ to $90^{\circ}$. Many of these chilled margins are associated with, or highly disrupted by, diffuse veining and brecciation. Veins and breccia domains both cut and are cut by chilled margins, and alteration is enhanced at chilled margins because the opening of cracks enables water to penetrate deeply into cooling lava. When secondary joints then develop normal to these new cooling surfaces they generate the highly distinctive joint system of "pseudo-pillow lava" (Walker, 1993). We excluded some similar "pseudo-pillows" here.

\section{Breccias/Cataclasites}

Three main types of breccia are generally classified as

1. Hyaloclastite related to extrusive or intrusive activity,

2. Incipient breccia related to cooling or cracking, and

3. Hydraulic breccia related to hydrothermal activity or intrapillow fluids.

In general, incipient breccias are more common in sheet flows. However, breccias recovered from Hole U1346A are mainly associated with chilled margins; most of them are intrapillow hydraulic breccias. Observed petrofabrics include local cataclastic domains such as broken rectangular slivers of basalt and recrystallization textures of matrix such as calcite. For example, the cataclastic unit in interval 324U1346A-16R-2, 111-116 cm, consists of rounded to angular rectangular clasts or slivers of basalt. In general, 3-4 cm of cataclasite separates basalt fragments from chilled fragments. The cataclastic zone is characterized by a complex network of tiny veins, mostly dark green, dark brown, white, and light green, on the core face (Fig. F35). Vein networks and cataclastic banding have caused incipient brecciation of the host rock, and larger fragments show only minor relative rotation.

\section{Joints}

Joints are important and common structures in the cores. They express a range of morphologies including planar, curved, irregular, and anastomosing. They can form complicated arrays including en echelon, parallel, conjugate, network, anastomosing, radial, and other structures. These are common in the cores of Hole U1346A. Most joints are related to the cooling of lava and are represented by curved, radial, Y-shaped, and irregular veins filled with secondary minerals. Joints are the major brittle fracture features, but veins are very common in fractured zones as well. Evidently, veins form where minerals precipitate in joints (Davis, 1984).

\section{Veins}

Most of the inspected pieces contain at least one vein, and veins are generally closely associated with joints such as conjugate veins (Fig. F37A). In some sets, veins have splays and intersect others with Yand T-shaped morphologies (Fig. F37B). These intersections can be complex, with changes in mineralogy along the length of the vein. Furthermore, many veins that apparently merge in hand samples have crosscutting relationships when observed in thin section. Crosscutting relationships can also be found as displacements at vein intersections.

Veins range in width, morphology, and composition and reflect the dynamics of hydrothermal fluid flow through the oceanic crust. Vein widths are generally $<5 \mathrm{~mm}$ (most are $\sim 0.1$ or $\sim 3 \mathrm{~mm}$ wide), with a maximum width of $10 \mathrm{~mm}$ in interval 324-U1346A-8R-2, $31-33 \mathrm{~cm}$.

Many veins, except those with well-defined walls, have halos in Hole U1346A. The color of the alteration halos reflects secondary mineral contents. Vein fill changes from oxyhydroxide and nontronite to calcite from edge to center of veins or vesicles in Hole U1346A (Fig. F37C). Calcite-rich veins commonly show polycrystalline fabrics and partly crossfiber fabrics. Sulfides in the veins are texturally late and in many instances in the vein center. There is obviously less pyrite observed in Hole U1346A than in the igneous cores recovered from Hole 1213B at Shatsky Rise (Shipboard Scientific Party, 2002b). The mineralogical zonation from nontronite on the vein walls to calcite in the center is possibly interpreted so that veins are asymmetrically grown in the vein 
center toward the opposite vein wall, wherein grains are growing during incremental opening of the vein. Then, the vein minerals do not replace the wall rock, further showing the vein filling style. Some models for asymmetric vein opening suggest that fibrous and elongate minerals can track the opening history (Ramsay and Huber, 1983).

\section{Shear veins}

Unlike Expedition 309 (Teagle, Alt, Umino, Miyashita, Banerjee, Wilson, and the Expedition 309/312 Scientists, 2006), where local cataclastic rocks were observed, faults and fault rocks were not recovered from Hole U1346A. However, several shear veins were recovered. In Section 324-U1346A-14R-1 (Fig. F38), some en echelon-aligned brown slivers are interpreted to have tracked the vein opening direction. Such structures are rare but indicate that vein opening was slightly noncoaxial, or termed a "shear vein." In the case of shear veins, vein opening was strongly oblique (Fig. F37D). Shear veins exhibit evidence for noncoaxial displacement either during or after their opening (Ramsay and Huber, 1983). Slickenfibers, also called mineral lineations, are present on some surfaces. Such planar surfaces commonly have steps in the slickenfibers, and the standard interpretation is that displacement was in the stepping-down direction (Ramsay and Huber, 1983). Only two of the five shear veins recovered exhibit sense of shear indicators, one sinistral and one dextral. Shear veins in thin section are filled with minor carbonate and smectite. Secondary minerals apparently predate much of the vein opening and provide passive markers for the opening history (Fig. F38).

\section{Macrostructures throughout Hole U1346A}

Multiple stages of intrusion and high-temperature (melt present) shear and multiple generations of flow at high and moderate temperature can be recognized using structural relationships. For example, the orientations of structures and their mutual relationships show that strain accommodated by veins, intrusions, and melt migration is intimately related to large-scale magmatic construction of the oceanic crust.

Based on the observations in Hole U1346A, the main structure is revealed to be a pile of stacked pillows whose sizes differ from 20 to $\sim 200 \mathrm{~cm}$ (Figs. F39, F40, F41, F42). These pillows still preserve the shape of a flat base and a rounded top. Many pieces show typical pillow structures, having heterogeneously and/or radially distributed cracks and veins. Our statistics of structural identifiers show that the veins have steeper dip angles than those of joints in the same section (Fig. F43), and dip angles of the veins from the top to the bottom become gradually steeper (Fig. F43).

Many vesicles, amygdaloid structures dominantly filled with calcite, are layered parallel to the pillow rims. On the other hand, some of the vesicles form elongated pipe structures pointing toward the rim and are perpendicular to the chilled margins. Both types of vesicles are generally concentrated along the rim of the individual pillow units resulting in lower vesicularity in the center. Only longer pipe vesicles $(>1 \mathrm{~cm})$, however, are also found in the central portion of the pillows (see interval 324-U1346A-14R-1, $67-94 \mathrm{~cm}$, right top in Fig. F41). These characteristic features are obviously different from the concentric variations of lobes of pahoehoe lava.

\section{Geochemistry}

\section{Major and trace element analysis}

We analyzed 22 samples of igneous rocks from stratigraphic Unit V of Hole U1346A for concentrations of major element oxides and several trace elements (Table T7) by inductively coupled plasma-atomic emission spectroscopy (ICP-AES) (see "Geochemistry" in the "Methods" chapter for information on analytical procedures, instrumentation, and data quality). Stratigraphic units above Unit V are not igneous and were not sampled for ICP-AES analysis. Most of the samples were highly altered, although a range of alteration from moderate to nearly total was represented (see "Alterations and metamorphic petrology"), in part to investigate the chemical effects of alteration. Two samples of $1-2 \mathrm{~cm}$ thick carbonaterich, light green veins (Samples 324-U1346A-7R-1 [Piece 3, 28-30 cm] and 7R-2 [Piece 7, 104-107 cm]) were also analyzed (Table T7).

Total weight percentages for the major element oxides in the igneous samples vary rather widely, from 93.50 to $101.65 \mathrm{wt} \%$ (and for one carbonate-rich vein, the total is only $85.09 \mathrm{wt} \%$ ). This variation may partly be a result of the inability of the muffle furnace to attain a temperature above $1000^{\circ} \mathrm{C}$ during the ignition step of sample preparation (see "Geochemistry" in the "Methods" chapter). In order to better compare our results with one another and with data from the literature, we normalized the raw major element values to $100 \mathrm{wt} \%$ totals; the normalized values are presented below the raw data in Table T7 and are used in the figures and in the discussion below.

Weight loss on ignition (LOI) serves as a good general indicator of overall alteration level in these rocks. Relative to LOI values for unaltered tholeiitic 
basalt (typically $<1 \mathrm{wt} \%$ ), values for the Site U1346 igneous samples are all very high, ranging from 3.12 to $13.85 \mathrm{wt} \%$ (Fig. F44A). LOI values for the two carbonate-rich veins are 30.97 and $34.34 \mathrm{wt} \%$. In a total alkalis versus $\mathrm{SiO}_{2}$ diagram (Fig. F45), data for the igneous samples fall in the fields of both tholeiitic basalt and more alkalic compositions. However, the samples with the lowest total alkali values are also those with the lowest LOI values $(<5.1 \mathrm{wt} \%)$, and data for these samples all lie in the field of tholeiitic basalt. The principal effect of alteration on the alkali elements appears to have been on $\mathrm{K}_{2} \mathrm{O}$, as $\mathrm{Na}_{2} \mathrm{O}$ shows little covariation with LOI and a limited range of variation (2.28 to $3.14 \mathrm{wt} \%$, except for one sample with $1.48 \mathrm{wt} \%$ ), whereas $\mathrm{K}_{2} \mathrm{O}$ exhibits a rough positive correlation with LOI and a very large overall range $(0.10$ to $4.77 \mathrm{wt} \%)$. Likewise, a general decrease of $\mathrm{SiO}_{2}$ with increasing alteration is recorded in a negative correlation of $\mathrm{SiO}_{2}$ with LOI. Other elements that were strongly affected by alteration include $\mathrm{Sr}, \mathrm{Ni}$, and $\mathrm{Co}$, all showing variable but often large increases in concentration, and $\mathrm{CaO}$, for which both increases and decreases are evident relative to the least-altered samples (most of the variation in $\mathrm{CaO} / \mathrm{Al}_{2} \mathrm{O}_{3}$ in the Site U1346 data in Figure F44B reflects variation in $\mathrm{CaO}$ content). Lesser, but still significant, effects are evident in variable increases in $\mathrm{Ba}$ and $\mathrm{P}_{2} \mathrm{O}_{5}$ concentrations, moderate decreases in $\mathrm{Fe}_{2} \mathrm{O}_{3}{ }^{\top}$ (the superscript indicates total iron as $\mathrm{Fe}_{2} \mathrm{O}_{3}$ ), and both moderate increases and decreases in $\mathrm{MgO}$. Despite the visually impressive differences between the brown and gray alteration observed at Site U1346, no systematic chemical differences between the two types are evident; we infer that the brown alteration, which came after the gray alteration (see "Alteration and metamorphic petrology"), had relatively little effect on element concentrations at the bulk rock scale.

Elements that appear to have been affected relatively little by alteration include $\mathrm{TiO}_{2}, \mathrm{Zr}, \mathrm{Y}, \mathrm{Sc}, \mathrm{V}$, and Cr. These elements display only small ranges, particularly $\mathrm{TiO}_{2}$ and $\mathrm{Zr}$, for which concentrations vary from 1.48 to $1.79 \mathrm{wt} \%$ and 73 to $87 \mathrm{ppm}$, respectively. For this group of elements, the concentrations and interelement ratios of the Site U1346 lavas are similar to those of basalts recovered from the Tamu Massif of Shatsky Rise at Site 1213 (e.g., Fig. F44C, F44D, F44E) and the Early Cretaceous (paleomagnetic Chron M8, 132.5 Ma; Ogg et al., 2008) oceanridge basalts recovered at ODP Leg 191 Site 1179 to the north of Shatsky Rise. (Site 1179 serves as a basement "reference site" for nonplateau oceanic crust formed in the same region and during the same period of time as Shatsky Rise.) More generally, data for these elements for the Site U1346 lavas cluster in or very near the field for ocean-ridge basalts, such as those of the present-day East Pacific Rise (Figs. F44, F45). Like the Site 1213 lavas, the Site U1346 basalts consistently look more like ocean-ridge basalts than they do those of other Pacific plateaus, although some compositional overlap is present (e.g., see the field for OJP basalts in the figures). In short, when erupted, the Site U1346 lavas appear to have been compositionally much like those at Site 1213, 870 $\mathrm{km}$ away and probably $\sim 5$ m.y. older.

\section{Total carbon and carbonate carbon}

Six samples of sedimentary material from Cores 324U1346A-4R and 5R were analyzed in replicate for carbonate content (percent carbonate). The carbonate values are baseline-corrected for $\mathrm{CO}_{2}$ in equilibrium with acid and scaled to a $100 \% \mathrm{CaCO}_{3}$ standard (see "Geochemistry" in the "Methods" chapter for an explanation of analytical procedures and instrumentation used for carbonate, total carbon, and organic carbon measurement). The samples were also analyzed for total carbon, although not in replicate. The content of organic carbon was estimated by subtracting the percentage of measured carbonate from that of total carbon. Results are presented and discussed in "Sedimentology."

\section{Physical properties}

Igneous rock, sedimentary rock, and sediments in Hole U1346A were characterized for physical properties as described in "Physical properties" in the "Methods" chapter. Whole-round sections of core with continuous intervals longer than $10 \mathrm{~cm}$ were run through the Whole-Round Multisensor Logger (WRMSL) for measurement of gamma ray attenuation (GRA) density and magnetic susceptibility. Sections longer than $50 \mathrm{~cm}$ were measured with the Natural Gamma Ray Logger. Twenty-five discrete oriented cubic samples were cut from the working half of the cores for measurement of moisture and density (MAD) properties as well as compressional $(P$ wave) velocities in three directions.

\section{Whole-Round Multisensor Logger measurements}

Measurements of magnetic susceptibility and bulk GRA density were obtained on whole-round cores. Hard rock coring often results in recovery of pieces rather than continuous sections. Measurements on the WRMSL are sensitive to gaps in the core or to small-diameter pieces (e.g., pebbles). Therefore, the raw data from the WRMSL were filtered to remove underestimated data as described in "Physical properties" in the "Methods" chapter. 


\section{Magnetic susceptibility}

Magnetic susceptibility results are summarized in Figure F46 and reported in $10^{-5}$ SI units. The raw data were corrected using a Bartington correction factor (Blum, 1997). The correction assumes that the core liner is filled. Because the liner is always less than filled, the data must be treated as minima. Magnetic susceptibility in the upper sedimentary sequence in Section 324-U1346A-4R-1 is $<10 \times 10^{-5}$ SI units with a notable peak of $>60 \times 10^{-5}$ in Section $5 \mathrm{R}-1$ between 129.8 and 130.2 mbsf (Fig. F47B). The sediment/ basement interface is characterized by a sharp increase in magnetic susceptibility to $>100 \times 10^{-5} \mathrm{SI}$ units at 139 mbsf. Throughout the basaltic sequence cored from Section 324-U1346A-6R-1 to 16R-2, magnetic susceptibility shows a wide range from $30 \times 10^{-}$ 5 to $\sim 1000 \times 10^{-5}$ SI units. A decrease in magnetic susceptibility in Section 324-U1346A-8R-1 is observed at 149 mbsf (Fig. F47C), which corresponds to a distinct color change associated with differing alteration styles (see "Alteration and metamorphic petrology"). In other cores, there appears to be statistically significant variation in magnetic susceptibility, independent of edge effects or gaps. A good example is Section 324-U1346A-16R-1 from 187.0 to 187.8 mbsf (Fig. F47D). This variation might be used as an indicator of changing mineralogy of the basalt.

\section{Gamma ray attenuation bulk density}

The results for GRA bulk density measurements are summarized in Figure F46. Caution should be used when interpreting the absolute density values from the whole-round track, since RCB drilling results in cores that do not fill the lining, thus yielding an underestimation of density. In general, the sedimentary sections have lower GRA density than the igneous sections. The turbiditic sequence (see "Sedimentology") in Section 324-U1346A-4R-2 from 121.1 to 121.8 mbsf has uniform density (Fig. F47A). The igneous material has generally uniform density throughout the core despite pervasive and variable degrees of alteration, veining, and cracks to which the material has been subjected (see "Alteration and metamorphic petrology" and "Structural geology").

\section{Natural Gamma Ray Logger}

NGR measurements are summarized in Figure F46. These measurements correlate well with those from downhole logging tools (see "Downhole logging"). Measurement count time was maximized whenever possible to produce the highest resolved spectrum.

NGR data are output in two forms: one is total counts per second for all of the naturally occurring radioactive elements (such as ${ }^{238} \mathrm{U}$ and ${ }^{40} \mathrm{~K}$ ) and the second form is a measure of the counts per second versus channel, where channel can be correlated to energy using "known" peaks. Basalts from Hole U1346A average $\sim 22$ cps (total counts). These relatively high counts could reflect alteration remobilization and enrichment of potassium. This is in general agreement with inductively coupled plasma (ICP) geochemical data showing $\mathrm{K}_{2} \mathrm{O}$ contents as high as 4.79 wt\% (see "Geochemistry").

As a first-order observation, sedimentary sequences are dominated by contribution of uranium and its decay products, whereas the NGR spectrum data for the underlying basaltic sequence are dominated by potassium and its daughter nuclides (Fig. F48). Section 324-U1346A-5R-1 has an extreme enrichment in uranium from 129.6 to 129.9 mbsf. Figure F47B illustrates the correlation of the high NGR counts with magnetic susceptibility. There is a $20 \mathrm{~cm}$ offset that may represent a true offset or could be due to core motion within the liner, as this section was partially unconsolidated.

\section{Moisture and density}

Measurements of bulk density, dry density, grain density, void ratio, water content, and porosity on discrete samples are given in Table T8. The average bulk density determined from discrete samples was $2.48 \mathrm{~g} / \mathrm{cm}^{3}$, whereas grain density averaged $2.79 \mathrm{~g} / \mathrm{cm}^{3}$. These are higher values compared to the GRA data from the WRMSL, confirming that whole-round measurements underestimate density since the core does not completely fill the core liner. There is a slight decrease in water content and void ratio with depth; however, other MAD properties have similar ranges throughout the core (Fig. F49).

\section{Compressional ( $P$-wave) velocity}

Compressional wave velocities were measured on 24 basaltic discrete samples and one limestone discrete sample (Fig. F46; Table T9). Oriented cubic samples had $P$-wave velocities measured in three orthogonal directions $(x, y$, and $z)$. The average values throughout the hole were $4.54 \mathrm{~km} / \mathrm{s}$ ( $x$-direction), $4.57 \mathrm{~km} / \mathrm{s}$ ( $y$-direction), and $4.55 \mathrm{~km} / \mathrm{s}$ (z-direction), which are within error of the $20 \mathrm{~m} / \mathrm{s}$ precision of the measurements. The limestone from Section 324-U1346A-5R1 (130.37 mbsf) had values of $3.82 \mathrm{~m} / \mathrm{s}$ ( $x$-direction), $3.93 \mathrm{~km} / \mathrm{s}$ ( $y$-direction), and $3.77 \mathrm{~km} / \mathrm{s}$ (z-direction). Maximum values in all three directions were 5.6-5.7 $\mathrm{km} / \mathrm{s}$, whereas minimum velocities were $3.5 \mathrm{~km} / \mathrm{s}$ in all three directions. None of the samples showed appreciable anisotropy. There is no trend in $P$-wave velocity with depth. As expected, $P$-wave velocity cor- 
relates well with bulk density determined from MAD measurements (Fig. F50)

\section{Thermal conductivity}

Thirteen measurements of thermal conductivity were made on the archive half of core sections (Fig. F46; Table T10). Determinations were made at irregular intervals, depending on the availability of material homogeneous and continuous enough for measurement, resulting in a sampling frequency of 1-2 per core. Thermal conductivity in basaltic material ranged from 1.37 to $1.68 \mathrm{~W} /(\mathrm{m} \cdot \mathrm{K})$ and averaged 1.52 $\mathrm{W} /(\mathrm{m} \cdot \mathrm{K})$. There was no apparent trend of thermal conductivity with depth. In order to preserve the few recovered sedimentary sections, destructive thermal conductivity measurements were not performed on sedimentary samples.

\section{Paleomagnetism}

The major goals of paleomagnetism studies on the recovered cores were to characterize the paleomagnetic remanence and resolve paleolatitude from the magnetization components recorded in the igneous rocks. We focused only on discrete sample measurements from the working halves of the cores using the Molspin Minispin magnetometer and alternating-field (AF) demagnetizations using the DTech degausser because we found strange behavior in demagnetization results given by the onboard $2 \mathrm{G}$ magnetometer. We also thermally demagnetized discrete samples (one per flow). The magnetization of the sediments was too low to be measured on the Molspin Minispin; therefore, we only carried out demagnetizations on the basalts.

\section{Working-half discrete sample measurements}

We measured and analyzed 20 discrete basalt samples $\left(7 \mathrm{~cm}^{3}\right)$ from various lithologies downhole (Table T11). Four samples were AF demagnetized up to $100 \mathrm{mT}$ in steps of 5 or $10 \mathrm{mT}$, and 16 were thermally demagnetized up to $600^{\circ} \mathrm{C}$. Magnetic susceptibility was measured after each heating step in order to detect possible mineralogical changes (see "Paleomagnetism" in the "Methods" chapter for more details). Room-temperature susceptibilities range between $7 \times 10^{-3}$ and $20 \times 10^{-3}$ SI. For most of the samples the natural remanent magnetization measurements and first few demagnetization steps show a steep vertical component typical of drilling overprint (e.g., Wilson, Teagle, Acton, et al., 2003), but this is usually erased at $\sim 10 \mathrm{mT}$ or $200^{\circ} \mathrm{C}$ (Fig. F51).

\section{Alternating-field demagnetizations}

After the removal of the drilling overprint, demagnetization characteristics show a dependence on lithology. In AF demagnetization, the two samples from highly altered cores show very low median destructive field (MDF) around $8 \mathrm{mT}$. In contrast, the two samples from less altered cores show slightly higher MDF values than that of highly altered material $(>10$ $\mathrm{mT}$ ) and exhibit univectoral decay toward the origin as demagnetization steps proceed (e.g., Sample 324U1346A-7R-2, 39-41 cm). Inclinations and declinations were calculated using principal component analyses (PCA) (Kirshvink, 1980) for the steps between 10 and $~ 80 \mathrm{mT}$. Low values of maximum angular deviation show that these directional results are of high quality.

\section{Thermal demagnetizations}

Most samples have fairly low unblocking temperatures, around $400^{\circ}-450^{\circ} \mathrm{C}$, which is characteristic of titanomagnetite (-maghemite) $\mathrm{Fe}_{3 \mathrm{x}} \mathrm{Ti}_{\mathrm{x}} \mathrm{O}_{4}$ with an ulvospinel fraction of around 0.3-0.4 (Hunt et al., 1995). Bulk magnetic susceptibilities measured at room temperature after each heating step stay more or less constant for heating steps up to $\sim 450^{\circ} \mathrm{C}$. At higher temperatures, susceptibilities increase to 2-3 times the room-temperature values (Fig. F51). This could indicate that the primary magnetic carrier could be titanomaghemite that inverts to strongly magnetic magnetite as a result of heating (Özdemir and O'Reilly, 1982). Directional results also show more erratic behavior for the steps higher than $\sim 450^{\circ} \mathrm{C}$. For this reason, inclination and declination of each sample were calculated using PCA (Kirshvink, 1980) between $\sim 300^{\circ} \mathrm{C}$ (after the removal of the overprint) and $\sim 450^{\circ} \mathrm{C}$. In this temperature range, directions are univectorial and toward the origin, again with small maximum angular deviation angles $\left(<8^{\circ}\right)$. Three samples for which it was not possible to isolate a stable component between the overprint and the alteration had to be rejected, but the other 13 demagnetizations were of good quality. They all give negative and shallow inclinations.

\section{Tectonic significance of remanence data}

The demagnetization results from Hole U1346A are characterized by shallow negative inclinations (Fig. F52). Calculated average paleoinclination from all the negative inclination data points at Site U1346 is $-20.5^{\circ}$ with standard deviation $(1 \sigma)$ of $\pm 5.4^{\circ}$. There is no systematic change in the downhole inclinations, supporting the theory that the lava flows observed in Hole U1346A were deposited during a single eruption event (see "Igneous petrology"). The average 
inclination of this hole indicates that the Shirshov Massif was formed close to the Equator. If the contemporaneous Earth's magnetic field was reversed, the massif was formed in the Northern Hemisphere, and if the magnetic field was normal, it was formed in the Southern Hemisphere. However, because we do not have enough constraint from surface magnetic anomalies and radiometric dating to determine the basement age and corresponding magnetic polarity, the location of Shirshov Massif formation remains uncertain.

\section{Downhole logging}

Downhole logging data obtained from Hole U13346A included natural and spectral gamma ray, density, photoelectric factor (PEF), and electrical resistivity measurements from three depths of investigation. Interpretations of gamma ray and electrical resistivity downhole logs were used to identify 14 logging units in Hole U1346A with 3 in the section covered by the BHA, 4 in the sedimentary sequences in the open hole interval, and 7 in the basaltic basement.

\section{Operations}

A wiper trip was completed throughout the open hole before the start of the wireline logging operations. The drill pipe was set at a depth of $118.9 \mathrm{~m}$ wireline matched depth below seafloor (WMSF), which is $\sim 16.4 \mathrm{~m}$ above the sediment/basement interface. The hole was circulated with $38.5 \mathrm{bbl}$ of attapulgite mud. Downhole logging operations lasted $11.7 \mathrm{~h}$ beginning at $1955 \mathrm{~h}$ on 18 September 2009. The wireline logging operations consisted of one tool string deployment and testing of the wireline heave compensator (WHC). Logging operations in Hole U1346A took place in rough sea conditions where the ship's heave was generally $4-5 \mathrm{~m}$, with occasional excursions up to $6 \mathrm{~m}$.

\section{Tool string deployment}

The wireline tool string deployment consisted of a $23.2 \mathrm{~m}$ long modified triple combo that included a logging equipment cable head (LEH-QT), digital telemetry cartridge (DTC-H), Hostile Environment Natural Gamma Ray Sonde (HNGS), Hostile Environment Natural Gamma Ray Cartridge (HNGC), LithoDensity Sonde Cartridge (LDSC), Hostile Environment Litho-Density Sonde (HLDS), Digital Telemetry Adapter (DTA-A), General Purpose Inclinometry Tool (GPIT), and the Digital Dual Induction Tool model E (DITE). Downhole logs were recorded in three passes: (1) a downlog from seafloor to $169.1 \mathrm{~m} \mathrm{WMSF}$, (2) an uplog (Pass 1) from 177.6 to 150.3 m WMSF, and (3) a second uplog (Pass 2) from 177.6 m WMSF to seafloor.

After the downlog was stopped and prior to starting Pass 1, $1.5 \mathrm{~h}$ was spent assessing downhole tool motion and optimizing the efficiency of the WHC for the water depth at Hole U1346A and heave conditions at the time of the logging operations. Once the best possible WHC parameters were chosen for the prevailing heave conditions, the tool string was lowered to $177.6 \mathrm{~m}$ WMSF to begin the first uplog. Pass 1 was completed with the HLDS caliper arm closed as the downhole tool motion was being assessed while moving the tool string at a constant speed and to prevent potential tool damage. After downhole tool motion conditions were considered acceptable, Pass 2 was completed with the HLDS caliper arms opened.

\section{Data processing}

Logging data were recorded onboard the JOIDES Resolution by Schlumberger and archived in digital log information standard (DLIS) format. Data were sent by satellite transfer to Lamont-Doherty Earth Observatory-Borehole Research Group, processed there, and transferred back to the ship for archival in the shipboard database. Processing and data quality notes are given below.

\section{Depth shifting}

Depth shifts that were applied to logging data were performed by selecting a reference (base) log (usually the total gamma ray log from the run with the greatest vertical extent and no sudden changes in cable speed), and features in equivalent logs from other passes are aligned by eye. In the case of Hole $\mathrm{U} 1346 \mathrm{~A}$, the base log was the gamma ray profile from Pass 2 of the HNGS-HLDS-GPIT-DITE tool string. The original logs were first shifted to the seafloor (-3630.9 m WMSF). The seafloor depth was determined by the step in gamma ray value. This differs by $0.9 \mathrm{~m}$ from the seafloor depth given by the drillers (Table T12). The depth adjustments that were required to bring the match log in line with the base log were applied to all the other data sets from the same tool string.

Proper depth shifting of wireline logging depths relative to pipe depths was essential to achieve scientific goals. The targets that offered potential wireline logging depth references were the seafloor and the sediment/basement interface. However, data acquired across the seafloor resulted from logging through the BHA, so data from this interval are of poor quality. 


\section{Data quality}

The quality of wireline logging data were assessed by evaluating whether logged values are reasonable for the lithologies encountered and by checking consistency between different passes of the same tool. Gamma ray logs recorded through the BHA should be used only qualitatively because of the attenuation of the incoming signal. The thick-walled BHA attenuates the signal more than the thinner walled drill pipe.

A wide $(>30.5 \mathrm{~cm})$ and/or irregular borehole affects most recordings, particularly those like the HLDS that require eccentralization and good contact with the borehole wall. The density log roughly correlates with the resistivity logs, but it is largely affected by the hole conditions. The hole diameter was recorded by the hydraulic caliper on the HLDS tool (LCAL), and it shows a very irregular borehole with intervals exceeding the maximum caliper aperture. Good repeatability was observed between Pass 1 and Pass 2, particularly for measurements of electrical resistivity, gamma ray, density, and PEF.

Bulk density (HLDS) data were recorded at a sampling rate of $2.54 \mathrm{~cm}$ in addition to the standard sampling rate of $15.24 \mathrm{~cm}$. The enhanced bulk density curve is the result of Schlumberger enhanced processing technique performed on the MAXIS system onboard the JOIDES Resolution. In normal processing, short-spacing data are smoothed to match long-spacing data; in the enhanced processing this is reversed. In a situation where there is good contact between the HLDS pad and the borehole wall (lowdensity correction) the results are improved because the short spacing has better vertical resolution.

\section{Preliminary results}

\section{Electrical resistivity measurements}

A total of three electrical resistivity curves were obtained with the DITE, the deep induction phasor (IDPH), medium induction phasor (IMPH), and the spherically focused $\log$ (SFL). The SFL, IMPH, and IDPH resistivity profiles represent different depths of investigation into the formation $(64,76$, and 152 $\mathrm{cm})$ and different vertical resolutions $(76,152$, and $213 \mathrm{~cm}$ ). Downhole open hole electrical resistivity measurements covered $16.4 \mathrm{~m}$ of the bottommost sedimentary sequences and the uppermost $42.2 \mathrm{~m}$ of the basement lithostratigraphic units. The DITE was the only tool that reached the bottom of the logged interval in Hole U1346A because it was the bottommost tool in the logging tool string (Fig. F19 in the "Methods" chapter).

In the bottommost sedimentary sequences the IMPH values range from 0.9 to $4.1 \Omega \mathrm{m}$, the IDPH values range from 0.6 to $18.6 \Omega \mathrm{m}$, and the SFLU values range from 1.1 to $3.6 \Omega \mathrm{m}$. In the uppermost basement lithostratigraphic units the IMPH measurements range from 2.1 to $101.5 \Omega \mathrm{m}$, the IDPH values range from 2.6 to $93.5 \Omega \mathrm{m}$, and the SFLU values range from 3 to $164 \Omega \mathrm{m}$ (Fig. F53).

All electrical resistivity curves show a gradual increase in the sedimentary sequences from the bottom of the BHA at $118.9 \mathrm{~m}$ WMSF to the sediment/ basement interface at $135.3 \mathrm{~m}$ WMSF (Fig. F53).

\section{Gamma ray measurements}

Standard, computed, and individual spectral contributions from ${ }^{40} \mathrm{~K},{ }^{238} \mathrm{U}$, and ${ }^{232} \mathrm{Th}$ were part of the gamma ray measurements obtained in Hole U1346A with the HNGS. The total gamma ray measurements through the BHA show several anomalies:

1. From seafloor to $\sim 11.7 \mathrm{~m}$ WMSF,

2. From 49.4 to $52.7 \mathrm{~m} \mathrm{WMSF}$, and

3. From $109.2 \mathrm{~m}$ to just past the BHA at $\sim 121.6 \mathrm{~m}$ WMSF.

The two deepest anomalies could represent oceanic anoxic Events (OAEs) 1a and 1b previously identified at Sites 1207 and 1213 (Robinson et al., 2004).

Downhole open hole gamma ray measurements covered $16.4 \mathrm{~m}$ of the bottommost sedimentary sequences and the uppermost $22.6 \mathrm{~m}$ of the basement lithostratigraphic units. The short overall coverage $(39.2 \mathrm{~m})$ was mainly due to the placement of the BHA, the topmost position of the HNGS within the tool string (Fig. F53), and the total logging depth achieved in Hole U1346A.

Total gamma ray measurements in the bottommost sediments of Hole U1346A are highly variable, from 13.5 to 105.1 gAPI with a mean of 39.3 gAPI. Potassium values are also relatively high with values between 0.09 and $2.81 \mathrm{wt} \%$, with a mean of $0.78 \mathrm{wt} \%$ (Fig. F54). Uranium values are mostly between 0.81 and $8.73 \mathrm{ppm}$, with a mean of $2.84 \mathrm{ppm}$. In contrast, thorium values are relatively low, from 0.05 to 1.55 ppm, with a mean of $0.51 \mathrm{ppm}$. The relatively high uranium peaks found in the sediment basement contact could be indicative of vigorous and focused hydrothermal fluid flow.

Gamma ray measurements in basaltic oceanic crust are typically low (e.g., Bartetzko et al., 2001; Barr et al., 2002); however, the basaltic basement drilled in Hole U1346A exhibits relatively high gamma ray values. Total gamma ray values (HSGR) obtained with the HNGS in the basement range from 14.7 to 62.5 gAPI, with a mean of 40.5 gAPI. Potassium values are also relatively high with basement values between 0.67 and $2.83 \mathrm{wt} \%$. High potassium values caused by alteration were also confirmed by geochemical 
analyses (see "Geochemistry"). Shipboard ICP-AES analyses show a similar range in $\mathrm{K}_{2} \mathrm{O}$ values as those obtained with the downhole logs (Fig. F54). Differences between the laboratory and downhole potassium analyses are most likely due to variations in depth scales (WSMF versus core depth below seafloor, method A) and variations in scales of measurements between the two methods. Uranium values are mostly between 0.09 and $3.28 \mathrm{ppm}$, with a mean of $1.16 \mathrm{ppm}$. Thorium ranges from 0.02 to $1.17 \mathrm{ppm}$, with a mean of $0.48 \mathrm{ppm}$. Elevated potassium values in the basaltic basement illustrate the high degree of alteration that was recorded in the cores recovered from Hole U1346A.

\section{Density and photoelectric factor}

Density values range from 1.09 to $1.96 \mathrm{~g} / \mathrm{cm}^{3}$ over the lowermost sediment section of the open hole (Fig. F55). In the uppermost basement section, density values are between 1.07 and $2.77 \mathrm{~g} / \mathrm{cm}^{3}$. A comparison between discrete physical property samples and downhole density log shows good agreement (Fig. F55). PEF values in the bottommost sediments range from 1.21 to $4.10 \mathrm{~b} / \mathrm{e}^{-}$, whereas in the basement values range between 1.31 and $5.14 \mathrm{~b} / \mathrm{e}^{-}$. Low density and PEF values correspond to intervals with enlarged borehole dimensions (Fig. F55).

\section{Magnetic field measurements}

Measurements of total magnetic moment, magnetic inclination, and magnetic intensity were obtained with the GPIT (Fig. F56). The mean magnetic inclination and total magnetic moment from 130 to $179.9 \mathrm{~m} \mathrm{WMSF}$ are $77^{\circ}$ and $1.2 \mathrm{Oe}$, respectively. The magnetic intensity is 1.2 Oe on the $z$-axis and varies between -0.4 and 0.4 Oe on the $x$ - and $y$-axes.

\section{Lithostratigraphic correlations}

Preliminary interpretation of the downhole log data divides Hole U1346A into several logging units within three main sections: the section covered by the BHA, the sedimentary sequences in open hole, and the basaltic basement (Figs. F53, F54, F55, F57). Logging units in the section covered or partially influenced by the BHA were interpreted on the basis of the gamma ray downhole logs, and only intervals that showed significant anomalies were characterized as logging units. Logging units within the open hole section that contained sedimentary sequences were also interpreted on the basis of the gamma ray fluctuations, whereas the basaltic basement was characterized using the resistivity logs.

Three logging units were qualitatively identified in the section covered by the BHA (Fig. F57):
1. Logging Unit Ip (seafloor to $\sim 13.4 \mathrm{~m}$ WMSF) shows a significant increase in total gamma ray measurements.

2. Logging Unit IIp (48-52.9 m WMSF) shows a sharp increase in gamma ray values, with the spectral gamma data showing that the peak has a significant contribution from uranium.

3. Logging Unit IIIp (109.3 m WMSF to the bottom of the BHA) shows a significant uranium peak of $\sim 1 \mathrm{ppm}$.

The sedimentary sequence in open hole below the BHA was divided into four logging units based on gamma ray downhole logs (Fig. F53):

1. Logging Unit Is (118.9-126 m WMSF) has low gamma ray values of $\sim 20 \mathrm{gAPI}$.

2. Logging Unit IIs (126-131.7 m WMSF) shows a large peak in gamma ray values to as much as $\sim 105$ gAPI with a large contribution from uranium of as much as $9 \mathrm{ppm}$. This logging unit may correspond to the limestones and silty limestones recovered in Core 324-U1346A-5R.

3. Logging Unit IIIs (131.7-134.1 m WMSF) is characterized by low gamma ray values averaging 34 gAPI.

4. Logging Unit IVs (134.1-135.3 m WMSF) shows high gamma ray values directly above the sediment/basement interface. This may correlate with a banded, partially deformed green limestone at the base of the sediment sequence (see "Sedimentology").

The basement sequence below $135.3 \mathrm{~m}$ WMSF is divided into seven logging units based on the downhole resistivity logs (Fig. F53):

1. Logging Unit Ib (135.3-144.8 m WMSF) shows a steady increase in resistivity from the sediment/ basement interface to $137.5 \mathrm{~m} \mathrm{WMSF}$ and then levels out with values of $\sim 18 \Omega \mathrm{m}$. Caliper data show the borehole is larger than the bit size in the unit with a diameter of $56 \mathrm{~cm}$. Density averages $2.5 \mathrm{~g} / \mathrm{cm}^{3}$.

2. Logging Unit IIb (144.8-148 m WMSF) shows lower resistivity values of $\sim 7.7 \Omega \mathrm{m}$.

3. Logging Unit IIIb (148-151.8 m WMSF) has resistivity values of $\sim 30 \Omega \mathrm{m}$ with a peak of $\sim 100 \Omega \mathrm{m}$ at $151.5 \mathrm{~m}$ WMSF.

4. Logging Unit IVb (151.8-157.1 m WMSF) is characterized by low resistivity values between 2.2 and $13 \Omega \mathrm{m}$.

5. Logging Unit Vb (157.1-165.3 m WMSF) has resistivity values between 16 and $110 \Omega \mathrm{m}$.

6. Logging Unit VIb (165.3 and $168 \mathrm{~m}$ WMSF) has resistivity values averaging $\sim 15 \Omega \mathrm{m}$.

7. Logging Unit VIIb (168-177.6 m WMSF) has resistivity values between 10 and $100 \Omega \mathrm{m}$. 
A comparison of the downhole potassium logs from Hole U1346A with other shallow oceanic basement environments such as the OJP (Hole 807C), East Pacific Rise (Hole 1256D), and the eastern flank of the Juan de Fuca Ridge (Hole U1301B) shows higher potassium contents at the Shirshov Massif (Fig. F58). The sediment/basement interface also shows elevated uranium concentrations in Hole U1346A in comparison to the other localities.

A qualitative match of the gamma ray and electrical resistivity logs to seismic Line TN037 5A was made by tying seafloor and sediment-basement gamma ray anomalies to prominent reflectors in the regional seismic interpretation (Fig. F59). This correlation also shows potential ties of logging Unit IIp in the sedimentary sequence that could represent an OAE previously interpreted in this area (Robinson et al., 2001) and logging Unit IIIb to a discontinuous basement reflector that may represent the top of a lava flow.

\section{References}

Alt, J.C., 1995. Subseafloor processes in mid-ocean ridge hydrothermal systems. In Humphris, S.E., Zierenberg, R., Mullineaux, L., and Thomson, R. (Eds.), Seafloor Hydrothermal Systems: Physical, Chemical, Biological and Geological Interactions within Hydrothermal Systems. Geophys. Monogr., 91:85-114.

Alt, J.C., 2004. Alteration of the upper oceanic crust: mineralogy, chemistry, and processes. In Elderfield, H., and Davis, E. (Eds.), Hydrogeology of the Oceanic Lithosphere: New York (Cambridge Univ. Press), 456-488.

Bach, W., Hegner, E., Erzinger, J., and Satir, M., 1994. Chemical and isotopic variations along the superfast spreading East Pacific Rise from 6 to $30^{\circ}$ S. Contrib. Mineral. Petrol., 116(4):365-380. doi:10.1007/BF00310905

Banerjee, N.R., Honnorez, J., and Muehlenbachs, K., 2004. Low-temperature alteration of submarine basalts from the Ontong Java Plateau. In Fitton, J.G., Mahoney, J.J., Wallace, P.J., and Saunders, A.D. (Eds.), Origin and Evolution of the Ontong Java Plateau. Geol. Soc. Spec. Publ., 229(1):259-273. doi:10.1144/GSL.SP.2004.229.01.15

Barr, S.R., Révillon, S., Brewer, T.S., Harvey, P.K., and Tarney, J., 2002. Determining the inputs to the Mariana Subduction Factory: using core-log integration to reconstruct basement lithology at ODP Hole 801C. Geochem., Geophys., Geosyst., 3(11):8901. doi:10.1029/ 2001GC000255

Bartetzko, A., Pezard, P., Goldberg, D., Sun, Y.-F., and Becker, K., 2001. Volcanic stratigraphy of DSDP/ODP Hole 395A: an interpretation using well-logging data. Mar. Geophys. Res., 22(2):111-127. doi:10.1023/ A:1010359128574

Batiza, R., and White, J.D.L., 2000. Submarine lavas and hyaloclastite. In Sigurdsson, H., Houghton, B.F., McNutt, S.R., Rymer, H., and Stix, J. (Eds.), Encyclopedia of Volcanoes: San Diego (Acad. Press), 361-381.
Blum, P., 1997. Physical properties handbook: a guide to the shipboard measurement of physical properties of deep-sea cores. ODP Tech. Note, 26. doi:10.2973/ odp.tn.26.1997

Bolli, H.M., Beckmann, J.-P., and Saunders, J.B., 1994. Benthic Foraminiferal Biostratigraphy of the South Caribbean Region: Cambridge (Cambridge Univ. Press).

Borella, P.E., Myers, R., and Mills, B., 1983. Sediment petrology of the hydrothermal mounds. In Honnorez, J., Von Herzen, R.P., et al., Init. Repts. DSDP, 70: Washington (U.S. Govt. Printing Office), 197-209. doi:10.2973/dsdp.proc.70.108.1983

Bown, P.R. (Ed.), 1998. Calcareous Nannofossil Biostratigraphy: Dordrecht, The Netherlands (Kluwer Academic Publ.).

Chafetz, H.S., and Reid, A., 2000. Syndepositional shallowwater precipitation of glauconitic minerals. Sediment. Geol., 136(1-2):29-42. doi:10.1016/ S0037-0738(00)00082-8

Chenet, A.-L., Courtillot, V., Fluteau, F., Gérard, M., Quidelleur, X., Khadri, S.F.R., Subbarao, K.V., and Thordarson, T., 2009. Determination of rapid Deccan eruptions across the Cretaceous-Tertiary boundary using paleomagnetic secular variation, 2 . Constraints from analysis of eight new sections and synthesis for a 3500-m-thick composite section. J. Geophys. Res., [Solid Earth], 114(B6):B06103. doi:10.1029/2008JB005644

Davis, G.H., 1984. Structural Geology of Rocks and Regions: New York (John Wiley \& Sons, Inc.).

Fitton, J.G., and Godard, M., 2004. Origin and evolution of magmas on the Ontong Java Plateau. In Fitton, J.G., Mahoney, J.J., Wallace, P.J., and Saunders, A.D. (Eds.), Origin and Evolution of the Ontong Java Plateau. Geol. Soc. Spec. Publ., 229(1):151-178. doi:10.1144/ GSL.SP.2004.229.01.10

Greene, A.R., Scoates, J.S., Weis, D., Katvala, E.C., Israel, S., and Nixon, G.T., 2010. The architecture of oceanic plateaus revealed by the volcanic stratigraphy of the accreted Wrangellia oceanic plateau. Geosphere, 6(1):4773. doi:10.1130/GES00212.1

Harder, H., 1980. Synthesis of glauconite at surface temperatures. Clays Clay Miner., 28(3):217-222. doi:10.1346/ CCMN.1980.0280308

Holbourn, A., and Kaminski, M.A., 1997. Lower Cretaceous deep-water benthic foraminifera of the Indian Ocean. Gzybowski Found., Spec. Publ., 4:1-175.

Hon, K., Kauahikaua, J., Denlinger, R., and Mackay, K., 1994. Emplacement and inflation of pahoehoe sheet flows: observations and measurements of active lava flows on Kilauea Volcano, Hawaii. Geol. Soc. Am. Bull., 106(3):351-370. doi:10.1130/ 0016-7606(1994)106<0351:EAIOPS>2.3.CO;2

Honnorez, J., 2003. Hydrothermal alteration vs. oceanfloor metamorphism. A comparison between two case histories: the TAG hydrothermal mound (Mid-Atlantic Ridge) vs. DSDP/ODP Hole 504B (equatorial East Pacific). Comp. Rendus Geosci., 335(10-11):781-824. doi:10.1016/j.crte.2003.08.009

Hunt, C.P., Moskowitz, B.M., and Banerjee, S.K., 1995. Magnetic properties of rocks and minerals. In Ahrens, 
T.J. (Ed.), Rock Physics and Phase Relations: A Handbook of Physical Constants. Am. Geophys. Union Ref. Shelf, 3:189-204.

Kirschvink, J.L., 1980. The least-squares line and plane and the analysis of palaeomagnetic data. Geophys. J. $R$. Astron. Soc., 62(3):699-718. doi:10.1111/j.1365246X.1980.tb02601.x

Klaus, A., and Sager, W.W., 2002. Data report: high-resolution site survey seismic reflection data for ODP Leg 198 drilling on Shatsky Rise, northwest Pacific. In Bralower, T.J., Premoli Silva, I., Malone, M.J., et al., Proc. ODP, Init. Repts., 198: College Station, TX (Ocean Drilling Program), 1-21. doi:10.2973/odp.proc.ir.198.111.2002

Koutsoukos, E.A.M., and Hart, M.B., 1990. Cretaceous foraminiferal morphogroup distribution patterns, palaeocommunities and trophic structures: a case study from the Sergipe Basin, Brazil. Trans. R. Soc. Edinburgh: Earth Sci., 81:221-246.

Le Maitre, R.W., Bateman, P., Dudek, A., Keller, J., Lameyre, J., Le Bas, M.J., Sabine, P.A., Schmid, R., Sorensen, H., Streckeisen, A., Woolley, A.R., and Zanettin, B., 1989. A Classification of Igneous Rocks and Glossary of Terms: Oxford (Blackwell).

Loeblich, A.R., Jr., and Tappan, H., 1988. Foraminiferal Genera and Their Classification: New York (Van Nostrand Reinhold).

Macdonald, G.A., 1968. Composition and origin of Hawaiian lavas. In Coats, R.R., Hay, R.L., and Anderson, C.A. (Eds.), Studies in Volcanology: A Memoir in Honor of Howel Williams. Mem.-Geol. Soc. Am., 116:477-522.

Macdonald, G.A., and Katsura, T., 1964. Chemical composition of Hawaiian lavas. J. Petrol., 5(1):82-133.

Mahoney, J.J., Duncan, R.A., Tejada, M.L.G., Sager, W.W., and Bralower, T.J., 2005. Jurassic-Cretaceous boundary age and mid-ocean-ridge-type mantle source for Shatsky Rise. Geology, 33(3):185-188. doi:10.1130/ G21378.1

Mahoney, J.J., Fitton, J.G., Wallace, P.J., et al., 2001. Proc. ODP, Init. Repts., 192: College Station, TX (Ocean Drilling Program). doi:10.2973/odp.proc.ir.192.2001

Mahoney, J.J., Sinton, J.M., Kurz, M.D., Macdougall, J.D., Spencer, K.J., and Lugmair, G.W., 1994. Isotope and trace element characteristics of a super-fast spreading ridge: East Pacific Rise $13-23^{\circ} \mathrm{S}$. Earth Planet. Sci. Lett., 121(1-2):173-193. doi:10.1016/ 0012-821X(94)90039-6

McNutt, M.K., and Fischer, K.M., 1987. The South Pacific superswell. In Keating, B.H., Fryer, P., Batiza, R., and Boehlert, G.W. (Eds.), Seamounts, Islands, and Atolls. Geophys. Monogr., 43:25-34.

Miyashiro, A., Shido, F., and Ewing, M., 1969. Diversity and origin of abyssal tholeiite from the Mid-Atlantic Ridge, $24^{\circ}$ and $30^{\circ}$ north latitude. Contrib. Mineral. Petrol., 23(1):38-52. doi:10.1007/BF00371331

Nakanishi, M., Sager, W.W., and Klaus, A., 1999. Magnetic lineations within Shatsky Rise, northwest Pacific Ocean: implications for hot spot-triple junction interaction and oceanic plateau formation. J. Geophys. Res., [Solid Earth], 104(B4):7539-7556. doi:10.1029/1999JB900002
Natland, J.H., Adamson, A.C., Laverne, C., Melson, W.G., and O'Hearn, T., 1983. A compositionally nearly steadystate magma chamber at the Costa Rica Rift: evidence from basalt glass and mineral data, Deep Sea Drilling Project Sites 501, 504, and 505. In Cann, J.R., Langseth, M.G., Honnorez, J., Von Herzen, R.P., White, S.M., et al., Init. Repts. DSDP, 69: Washington, DC (U.S. Govt. Printing Office), 811-858. doi:10.2973/ dsdp.proc.69.154.1983

Natland, J.H., and Hekinian, R., 1982. Hydrothermal alteration of basalts and sediments at Deep Sea Drilling Project Site 456, Mariana Trough. In Hussong, D.M., Uyeda, S., et al., Init. Repts., DSDP, 60: Washington, DC (U.S. Govt. Printing Office), 759-767. doi:10.2973/ dsdp.proc.60.144.1982

Natland, J.H., Tarney, J., Marsh, N.G., Melson, W.G., and O'Hearn, T., 1984. Compositions, stratigraphy and alteration of pillow basalts, Deep Sea Drilling Project Hole 543A, near the Barbados Ridge. In Moore, C., BijuDuval, B., et al., Init. Repts. DSDP, 78A: Washington (U.S. Govt. Printing Office), 393-399. doi:10.2973/ dsdp.proc.78a.118.1984

Newman, S., and Lowenstern, J.B., 2002. VolatileCalc: a silicate melt $-\mathrm{H}_{2} \mathrm{O}-\mathrm{CO}_{2}$ solution model written in Visual Basic for Excel. Comput. Geosci., 28(5):597-604. doi:10.1016/S0098-3004(01)00081-4

Ogg, J.G., Ogg, G., and Gradstein, F.M., 2008. The Concise Geologic Time Scale: Cambridge (Cambridge Univ. Press). http://www.cambridge.org/catalogue/catalogue.asp?isbn=9780521898492

Özdemir, Ö., and O’Reilly, W., 1982. Magnetic hysteresis properties of synthetic monodomain titanomaghemites. Earth Planet. Sci. Lett., 57(2):437-447. doi:10.1016/0012-821X(82)90162-5

Passchier, C.W., and Trouw, R.A.J., 1996. Microtectonics: Berlin (Springer-Verlag).

Ramsay, J.G., and Huber, M.I., 1987. The Techniques of Modern Structural Geology (Vol. 2): Folds and Fractures: New York (Acad. Press).

Robinson, S.A., Williams, T., and Bown, P.R., 2004. Fluctuations in biosiliceous production and the generation of Early Cretaceous oceanic anoxic events in the Pacific Ocean (Shatsky Rise, Ocean Drilling Program Leg 198). Paleoceanography, 19(4):PA4024. doi:10.1029/ 2004PA001010

Sager, W.W., Handschumacher, D.W., Hilde, T.W.C., and Bracey, D.R., 1988. Tectonic evolution of the northern Pacific plate and Pacific-Farallon Izanagi triple junction in the Late Jurassic and Early Cretaceous (M21-M10). Tectonophysics, 155(1-4):345-364. doi:10.1016/00401951(88)90274-0

Sager, W.W., Kim, J., Klaus, A., Nakanishi, M., and Khankishieva, L.M., 1999. Bathymetry of Shatsky Rise, northwest Pacific Ocean: implications for ocean plateau development at a triple junction. J. Geophys. Res., [Solid Earth], 104(4):7557-7576. doi:10.1029/1998JB900009

Self, S., Keszthelyi, L., and Thordarson, T., 1998. The importance of pahoehoe. Annu. Rev. Earth Planet. Sci, 26:81-110. doi:10.1146/annurev.earth.26.1.81 
Shipboard Scientific Party, 2002a. Leg 198 summary. In Bralower, T.J., Premoli Silva, I., Malone, M.J., et al., Proc. ODP, Init. Repts., 198: College Station, TX (Ocean Drilling Program), 1-148. doi:10.2973/ odp.proc.ir.198.101.2002

Shipboard Scientific Party, 2002b. Site 1213. In Bralower, T.J., Premoli Silva, I., Malone, M.J., et al., Proc. ODP, Init. Repts., 198: College Station, TX (Ocean Drilling Program), 1-110. doi:10.2973/odp.proc.ir.198.109.2002

Sinton, J.M., Smaglik, S.M., Mahoney, J.J., and Macdonald, K.C., 1991. Magmatic processes at superfast spreading mid-ocean ridges: glass compositional variations along the East Pacific Rise $13^{\circ}-23^{\circ} \mathrm{S}$. J. Geophys. Res., [Solid Earth], 96:6133-6155. doi:10.1029/90JB02454

Sliter, W.V., 1977. Cretaceous foraminifers from the southwestern Atlantic Ocean, Leg 36, Deep Sea Drilling Project. In Barker, P.F., Dalziel, I.W.D., et al., Init. Repts. DSDP, 36: Washington, DC (U.S. Govt. Printing Office), 519-573. doi:10.2973/dsdp.proc.36.110.1977

Sliter, W.V., and Baker, R.A., 1972. Cretaceous bathymetric distribution of benthic foraminifers. J. Foraminiferal Res., 2(4):167-183. doi:10.2113/gsjfr.2.4.167

Smith, W.H.F., and Sandwell, D.T., 1997. Global sea floor topography from satellite altimetry and ship depth soundings. Science, 277(5334):1956-1962. doi:10.1126/ science.277.5334.1956

Teagle, D.A.H., Alt, J.C., Umino, S., Miyashita, S., Banerjee, N.R., Wilson, D.S., and Expedition 309/312 Scientists, 2006. Proc. IODP, 309/312: Washington, DC (Integrated Ocean Drilling Program Management International, Inc.). doi:10.2204/iodp.proc.309312.2006

Tejada, M.L.G., Mahoney, J.J., Duncan, R.A., and Hawkins, M.P., 1996. Age and geochemistry of basement and alkalic rocks of Malaita and Santa Isabel, Solomon Islands, southern margin of Ontong Java Plateau. J. Petrol. 37(2):361-394. doi:10.1093/petrology/37.2.361
Tejada, M.L.G., Mahoney, J.J., Neal, C.R., Duncan, R.A., and Petterson, M.G., 2002. Basement geochemistry and geochronology of Central Malaita, Solomon Islands, with implications for the origin and evolution of the Ontong Java Plateau. J. Petrol., 43(3):449-484. doi:10.1093/petrology/43.3.449

Thorpe, R.S., and Brown, G.C., 1985. Geological Society of London Handbook: The Field Description of Igneous Rocks: Milton Keynes, U. K. (Open Univ. Press)

Walker, G.P.L., 1991. Structure, and origin by injection of lava under surface crust, of tumuli, "lava rises," "lavarise pits," and "lava-inflation clefts" in Hawaii. Bull. Volcanol., 53(7):546-558. doi:10.1007/BF00298155

Walker, G.P.L., 1993. Mantle and magmatic processes: basaltic-volcano systems. Geol Soc. Spec. Publ., 76(1):338. doi:10.1144/GSL.SP.1993.076.01.01

Wilson, D.S., Teagle, D.A.H., Acton, G.D., et al., 2003. Proc. ODP, Init. Repts., 206: College Station, TX (Ocean Drilling Program). doi:10.2973/odp.proc.ir.206.2003

Winterer, E.L., and Sager, W.W., 1995. Synthesis of drilling results from the Mid-Pacific Mountains: regional context and implications. In Winterer, E.L., Sager, W.W., Firth, J.V., and Sinton, J.M. (Eds.), Proc. ODP, Sci. Results, 143: College Station, TX (Ocean Drilling Program), 497535. doi:10.2973/odp.proc.sr.143.245.1995

Umino, S., Nonaka, M., and Kauahikaua, J., 2006. Emplacement of subaerial pahoehoe lava sheet flows into water: 1990 Kupaianaha flow of Kilauea Volcano at Kaimu Bay, Hawai'i. Bull. Volcanol., 69(2):125-139. doi:10.1007/s00445-006-0059-4

Yamagishi, H., 1994. Subaqueous Volcanic Rocks: Atlas and Glossary: Sapporo, Japan (Hokkaido Univ. Press).

Publication: 3 November 2010 MS 324-103 
Figure F1. Bathymetry of Shirshov Massif and location of Site U1346. Contours and colors indicate bathymetric depths predicted by satellite altimetry (Smith and Sandwell, 1997). Site 1207 was cored during ODP Leg 198 (Shipboard Scientific Party, 2002a). Contours shown at $200 \mathrm{~m}$ intervals; dark contours shown for kilometer multiples. Red line $=$ track of Cruise TN037 site survey (Klaus and Sager, 2002).

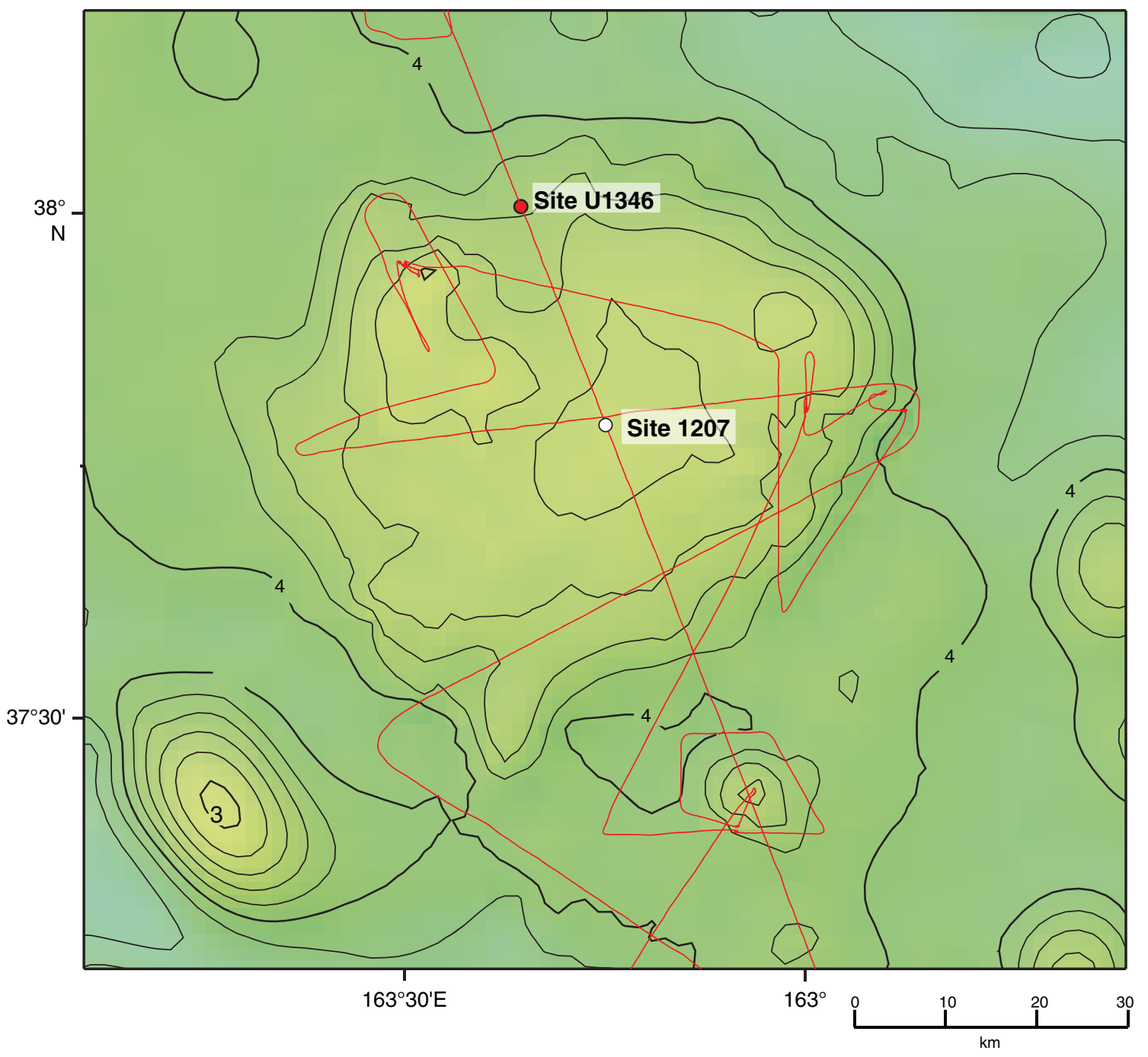


Figure F2. Seismic section and precruise layer interpretation (color overlay), Site U1346 (see Klaus and Sager, 2002). UTC = Universal Time Coordinated.

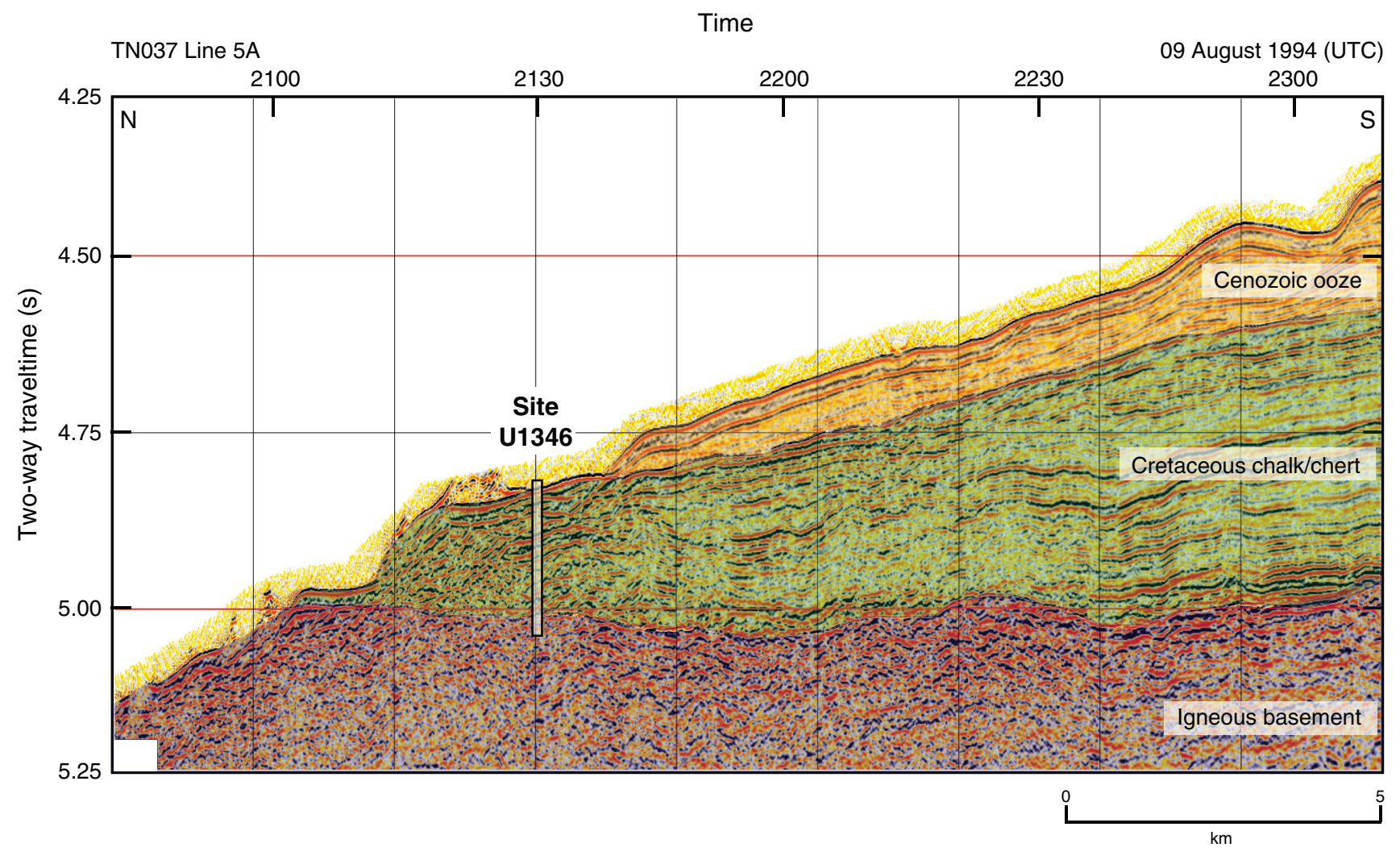


Figure F3. Plot of operation time vs. penetration depth, Hole U1346A. Dashed line = planned penetration progress, blue line $=$ actual depth achieved. $\mathrm{RCB}=$ rotary core barrel.

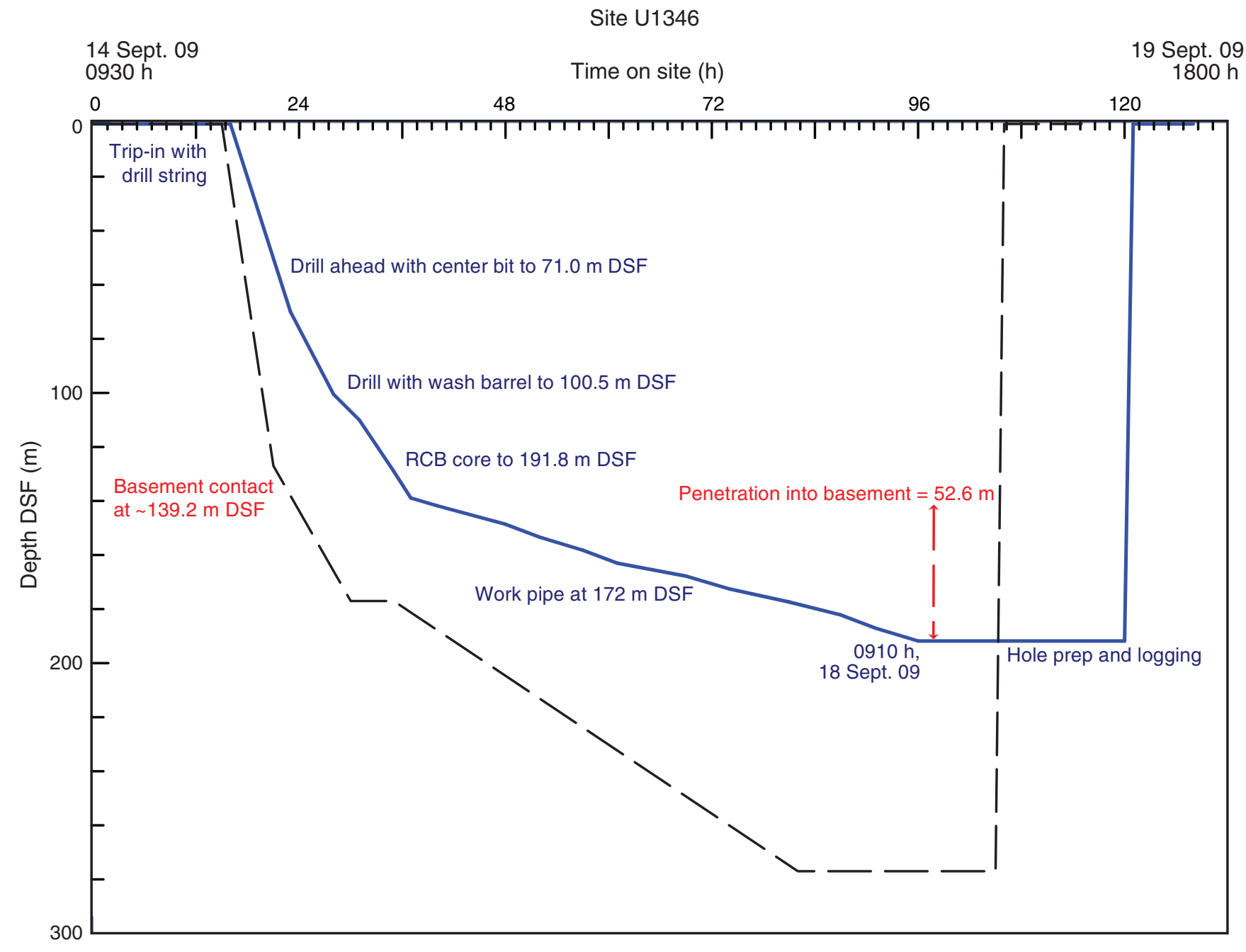


Figure F4. Lithostratigraphic summary and depositional environment interpretation, Site U1346.

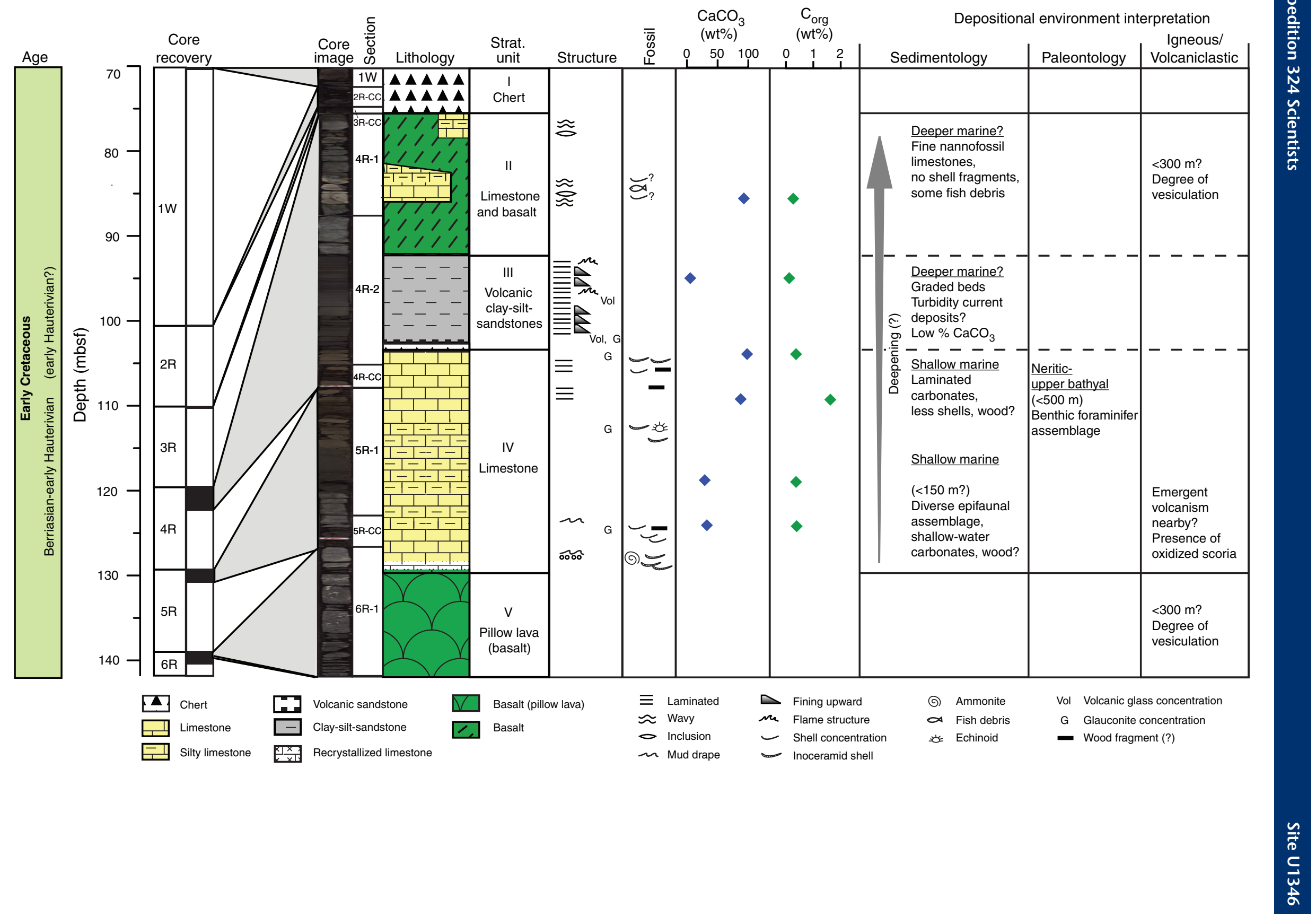


Figure F5. Microphotograph of thin section (interval 324-U1346A-4R-1, 24-31 cm). Image of typical radiolarian-rich dark gray limestone that interbeds with basalt. Cross-polarized light.

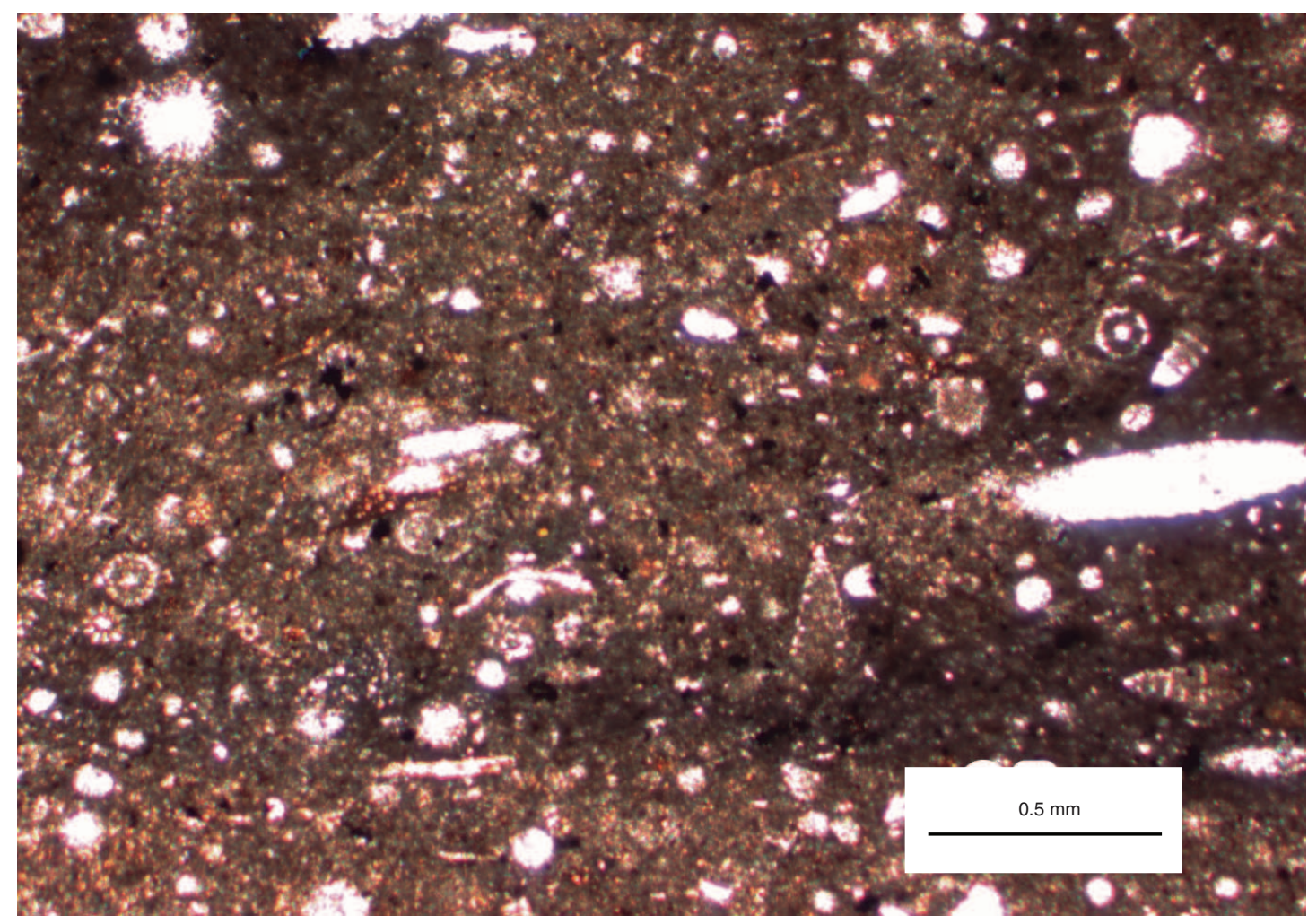


Figure F6. Photograph of whole round (interval 324-U1346A-4R-1, 56-67 cm) showing intermingling of green altered basalt with gray limestone and distorted primary bedding in the sediment.

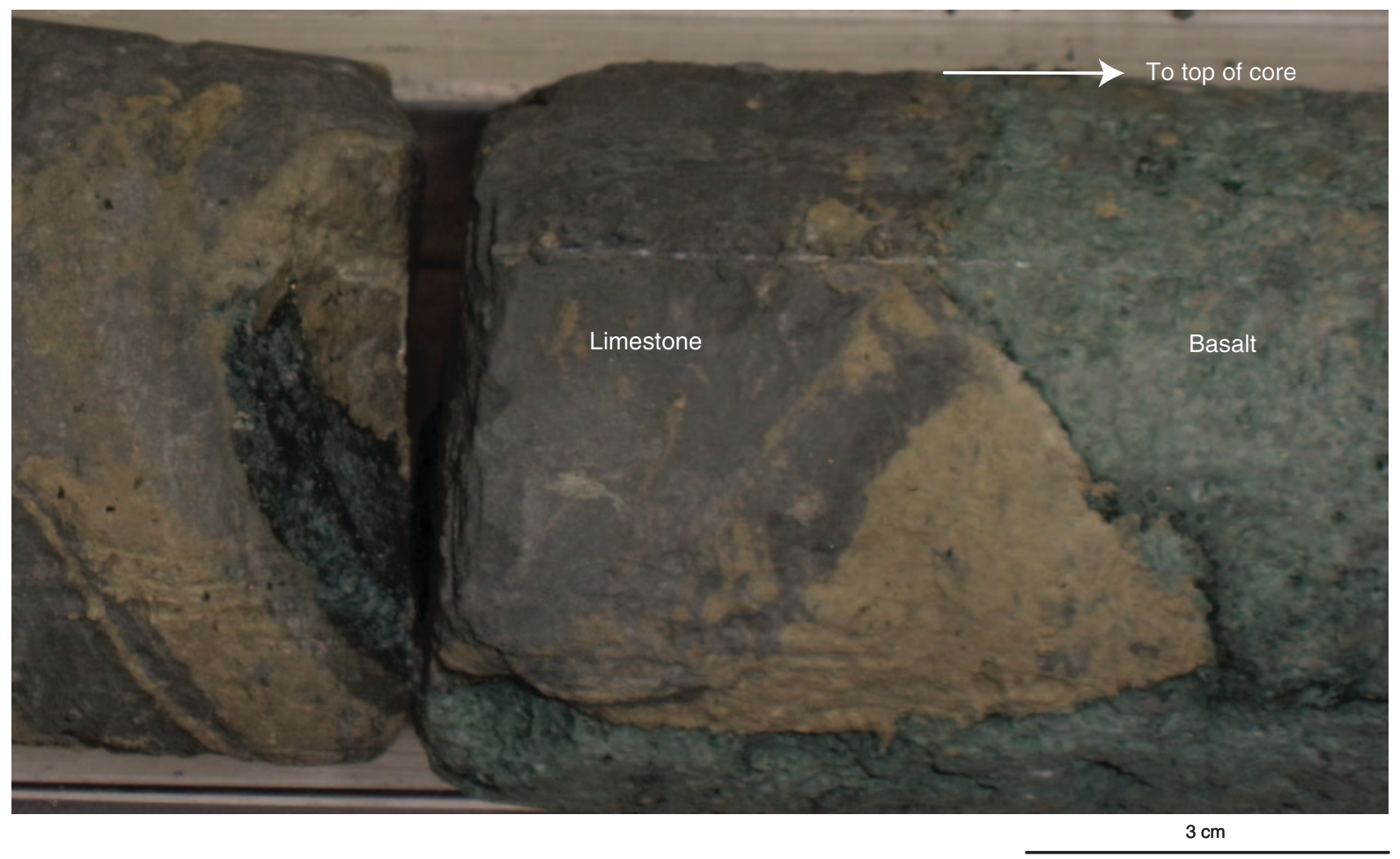


Figure F7. A. Photograph of normally graded sequences (interval 324-U1346A-4R-2, 50-59 cm). Arrows = fining upward. B. Smear slide image of fine clayey material in graded sequence. Volcanic glass shard is circled in red. Plane-polarized light. C. Thin section of coarse volcanic sandstone (interval 324-U1346A-4R-2, 127-131 cm). D. Bioturbated horizon (interval 324-U1346A-4R-2, 107-108 cm) indicating period of quiescence before next depositional event. E. Flame structures (interval 324-U1346A-4R-2, 122-124 cm) indicating sediment deposition in turbulent flow conditions.

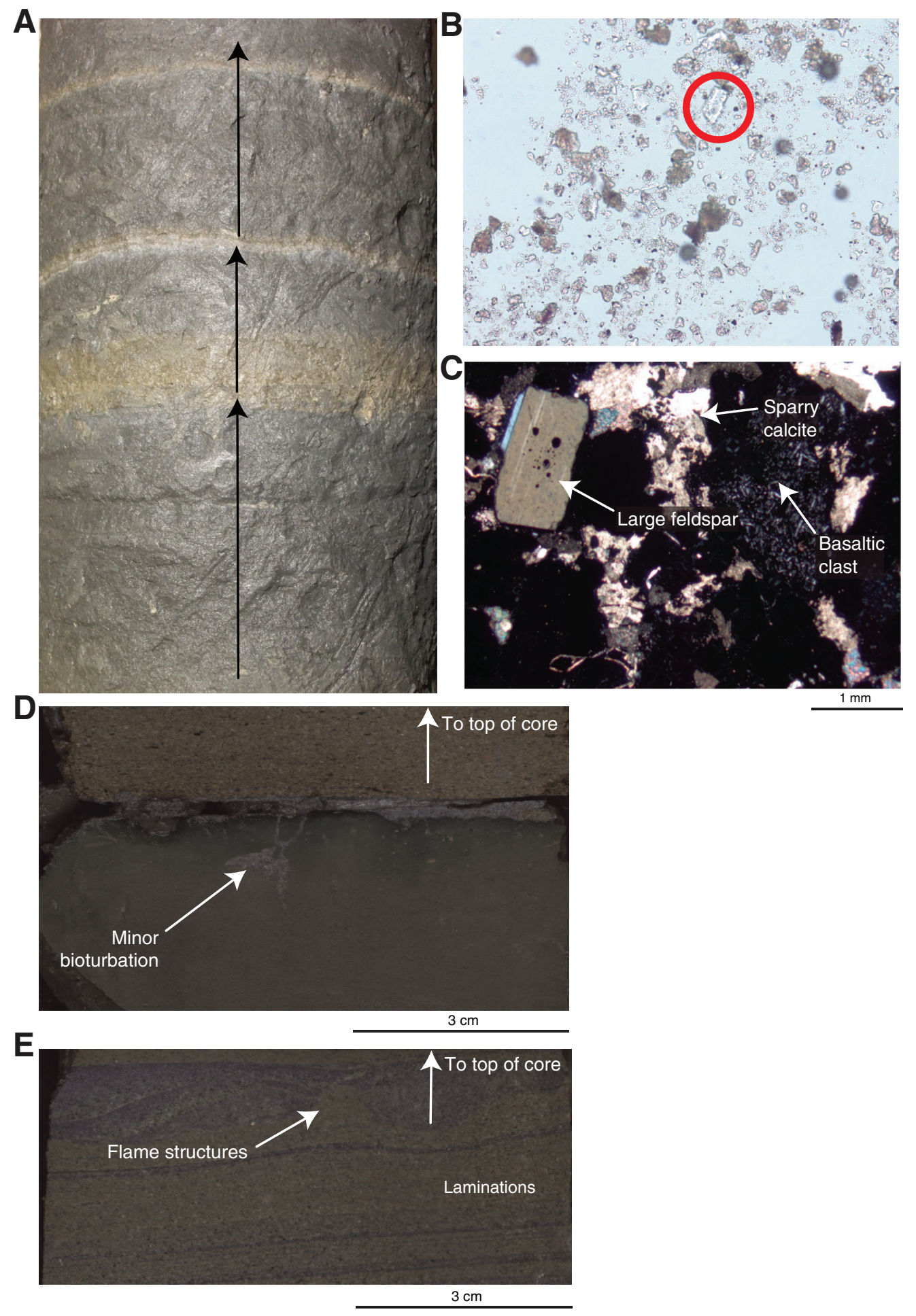


Figure F8. Photomicrographs of fossils observed in thin sections from bioclastic silty limestones of Unit IV. A. Large fragments of inoceramid bivalves, with other small shelly fragments and glauconite in a micritic matrix (Sample 324-U1346A-4R-2, 135-139 cm). Cross-polarized light. B. Echinoderm fragment (center) in brown micritic matrix (Sample 324-U1346A-4R-2, 135-139 cm). Plane-polarized light. C. Small gastropod shell (center), with other shelly fragments and glauconite clast (top left) (Sample 324-U1346A-5R-1, 57-61 cm). Cross-polarized light. D. Benthic foraminifer in a brown micritic matrix (Sample 324-U1346A-5R-1, 57-61 cm). Plane-polarized light.

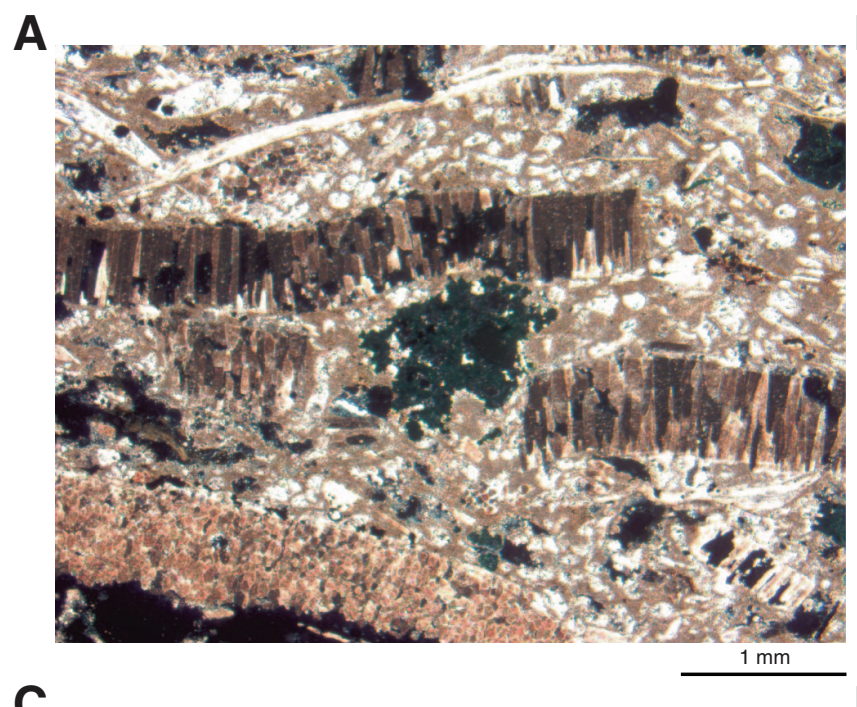

B
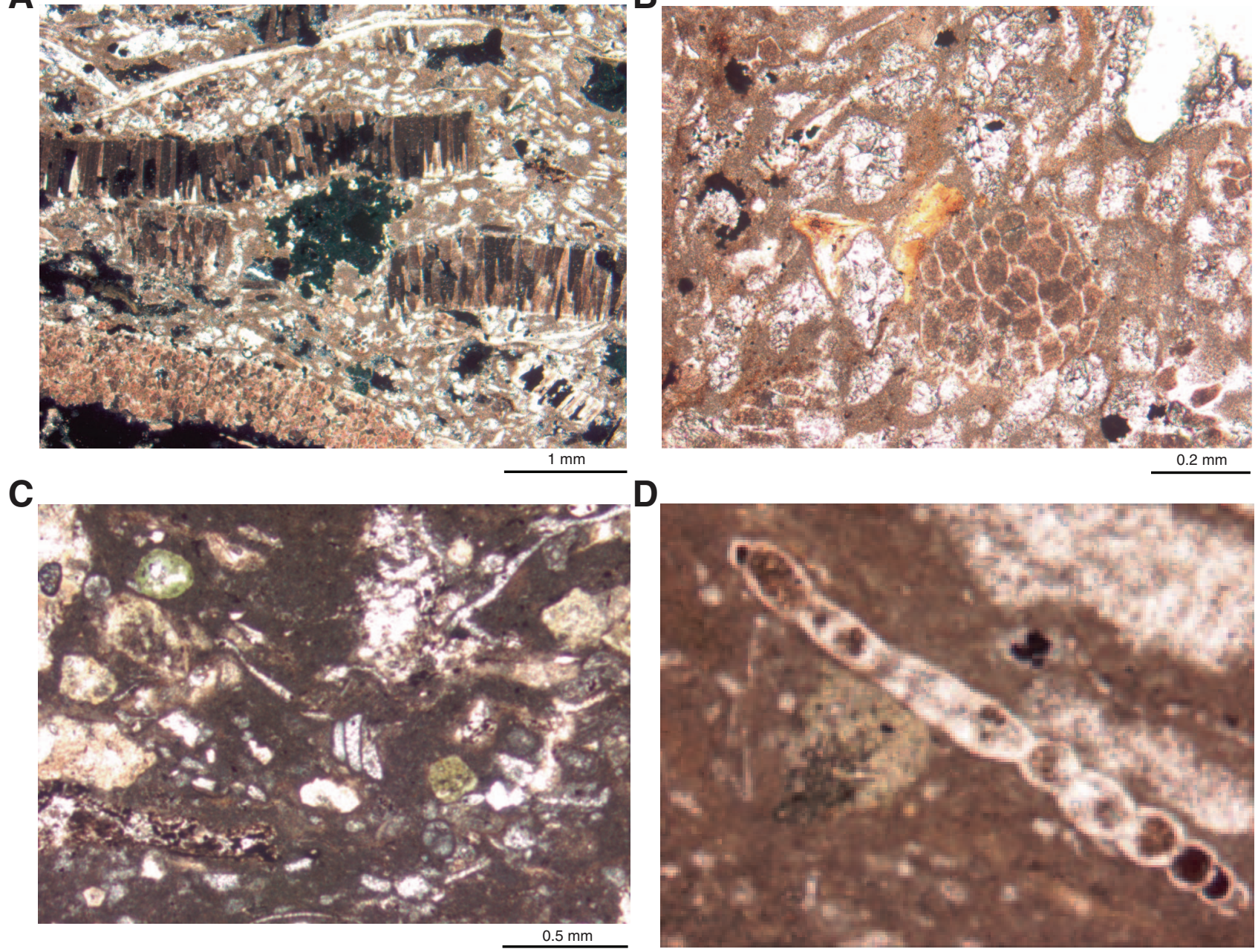

D

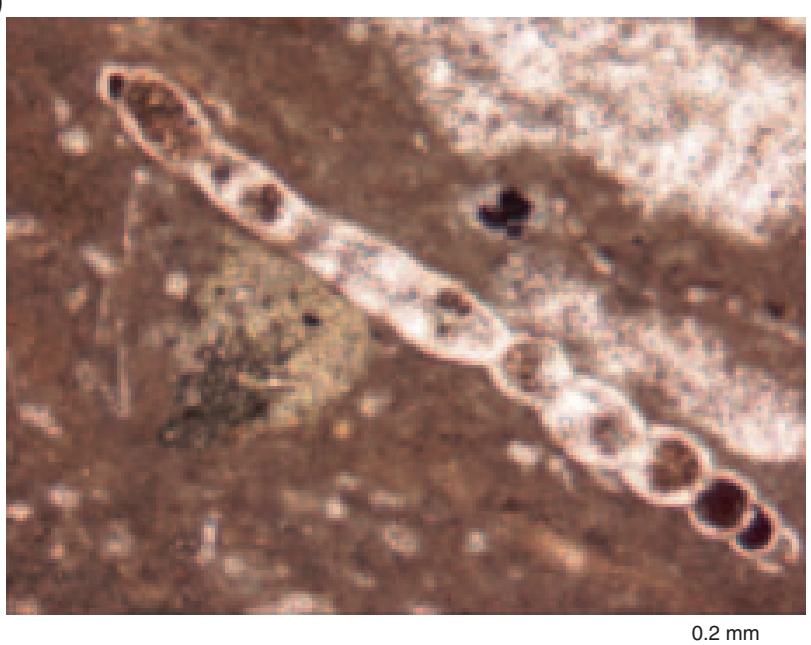


Figure F9. Light microscopic images of selected calcareous nannofossils. Taxonomic concept follows that used in Bown (1998). Black background = cross-polarized light images, light background $=$ phase contrast images. Scale bar $=2 \mu \mathrm{m}$. A, B. Cruciellipsis cuvillieri (Sample 324-U1346A-2R-1, $1 \mathrm{~cm}$ ). C, D. Speetonia sp. (Sample 324U1346A-2R-1, $1 \mathrm{~cm}$ ). E, F. Coccosphere (Sample 324-U1346A-2R-CC). G, H. Rotelapillus laffittei (Sample 324U1346A-5R-1, 53-54 cm).

A

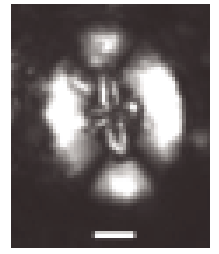

C

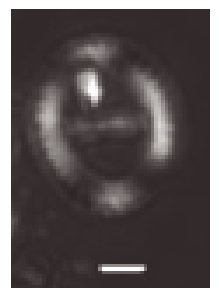

$\mathbf{E}$

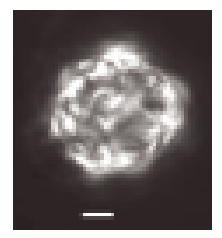

G

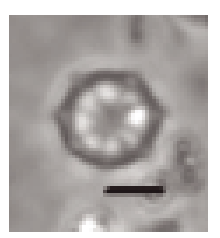

B

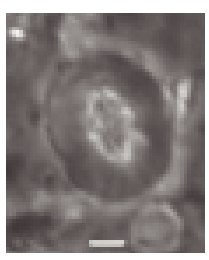

D

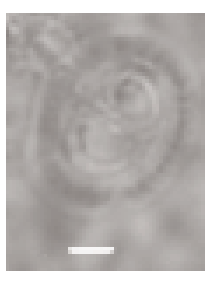

$\mathbf{F}$

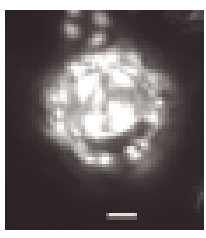

H

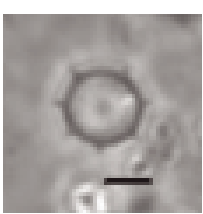


Figure F10. Overview of Cores 324-U1346A-4R through 16R. $L^{*}=$ SHMSL reflectance, NGR = natural gamma radiation, GRA = gamma ray attenuation bulk density, MS = magnetic susceptibility (see "Physical properties" for more details).

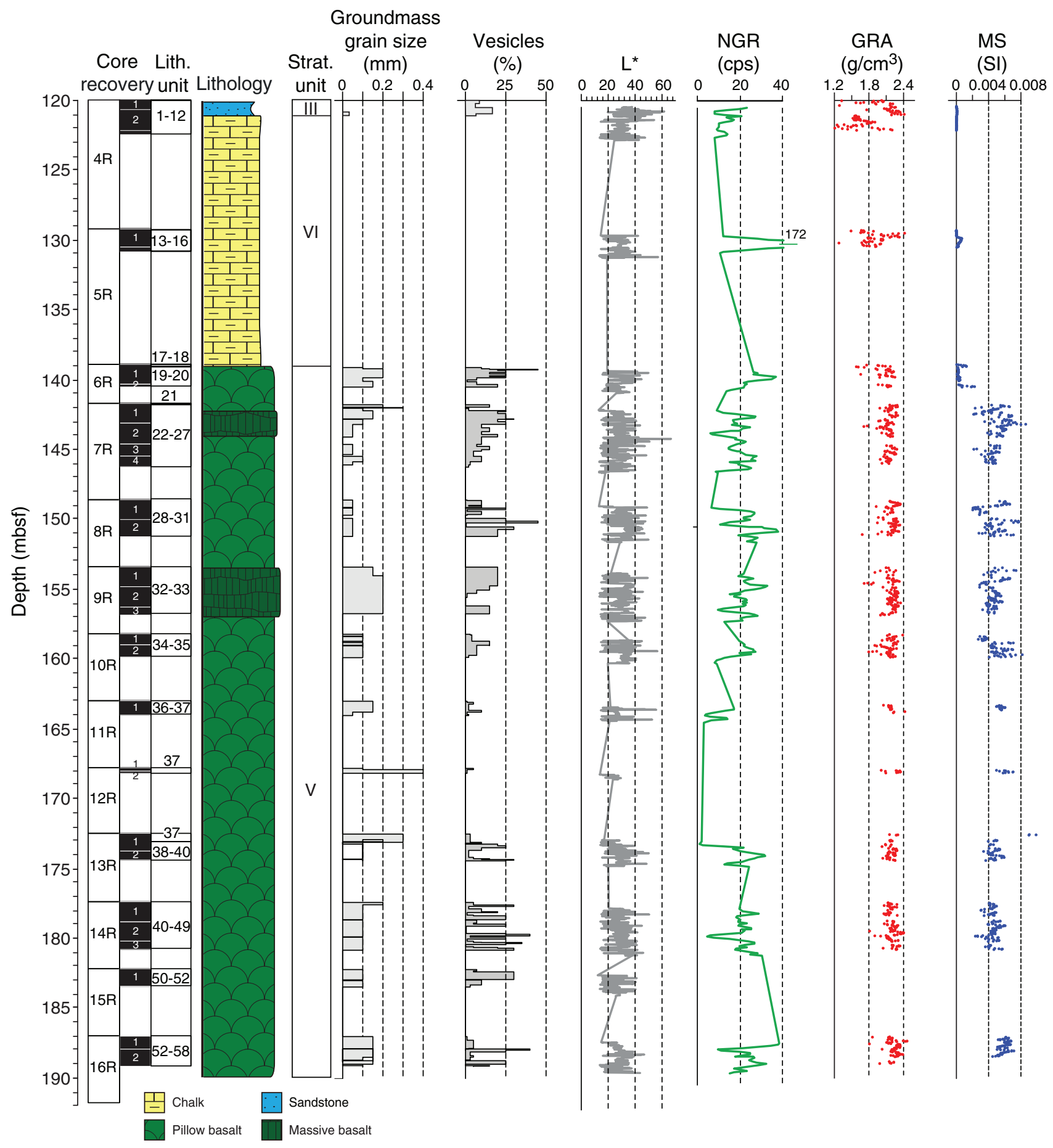


Figure F11. Core images annotated with volcanological features. In particular, all the amygdaloidal closepacked pillow basalt below Section 324-U1346A-6R-1 exhibits many primary magmatic features, including chilled pillow margins, spalled rims and interpillow carbonate, parallel zones of amygdules, tension cracks, pipe vesicles, and gas blisters. A. Sections 324-U1346A-4R-1 through 7R-2. (Continued on next three pages.)

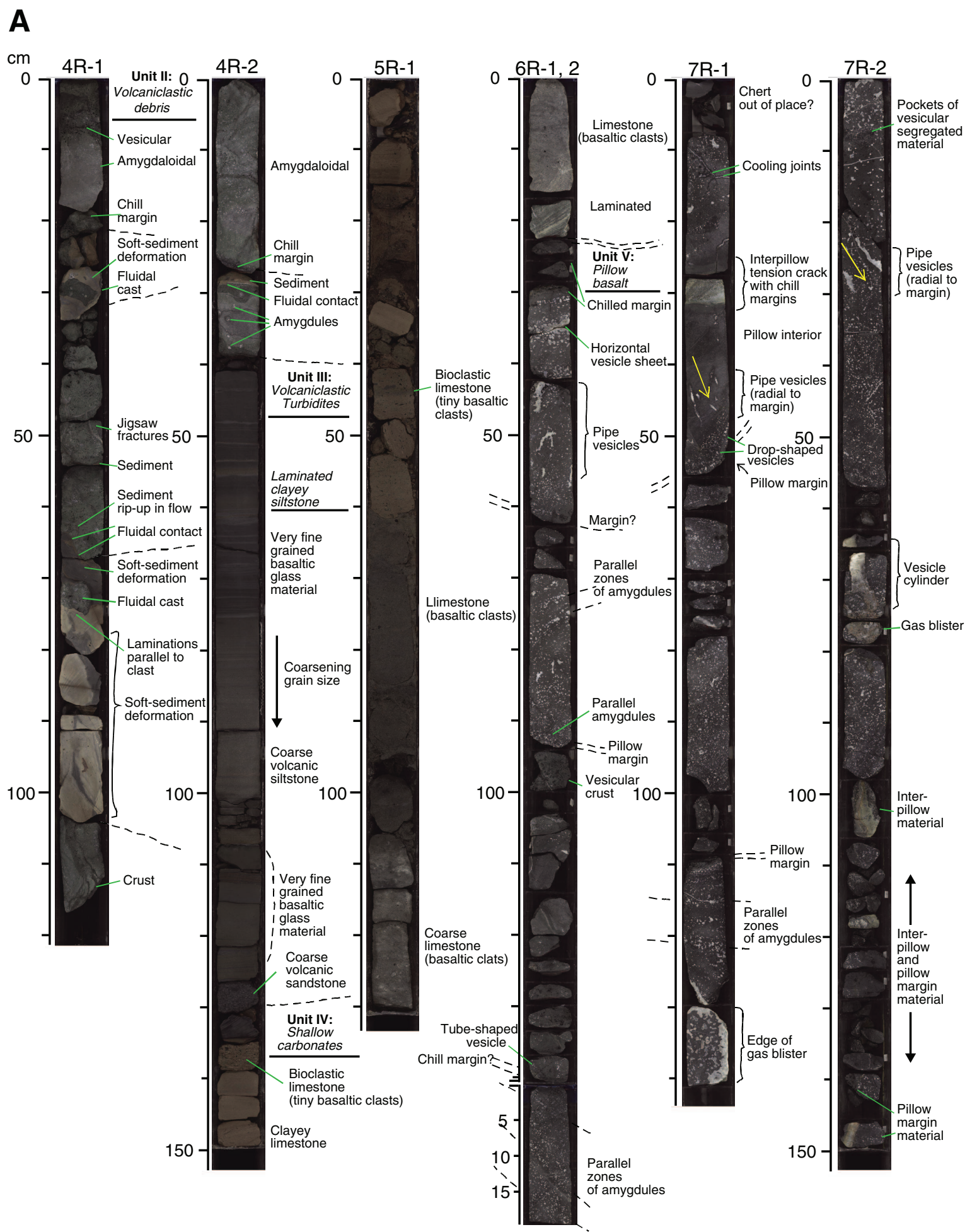


Figure F11 (continued). B. Sections 324-U1346A-7R-3 through 10R-1. (Continued on next page.)

B

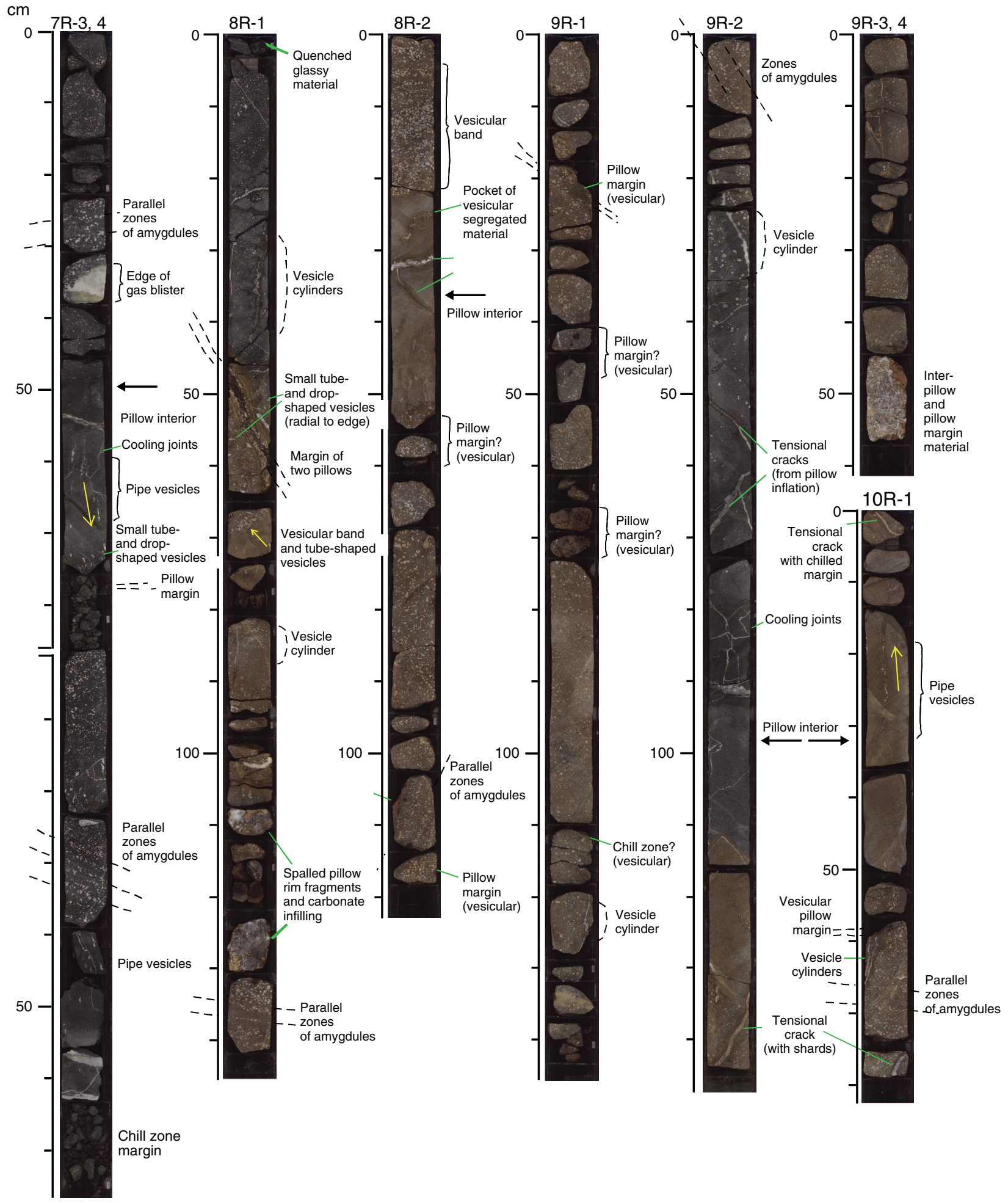


Figure F11 (continued). C. Sections 324-U1346A-10R-2 through 14R-2. Several smaller core sections are aligned in the same column (e.g. Sections 324-U1346A-12R-1 and 12R-2). (Continued on next page.)

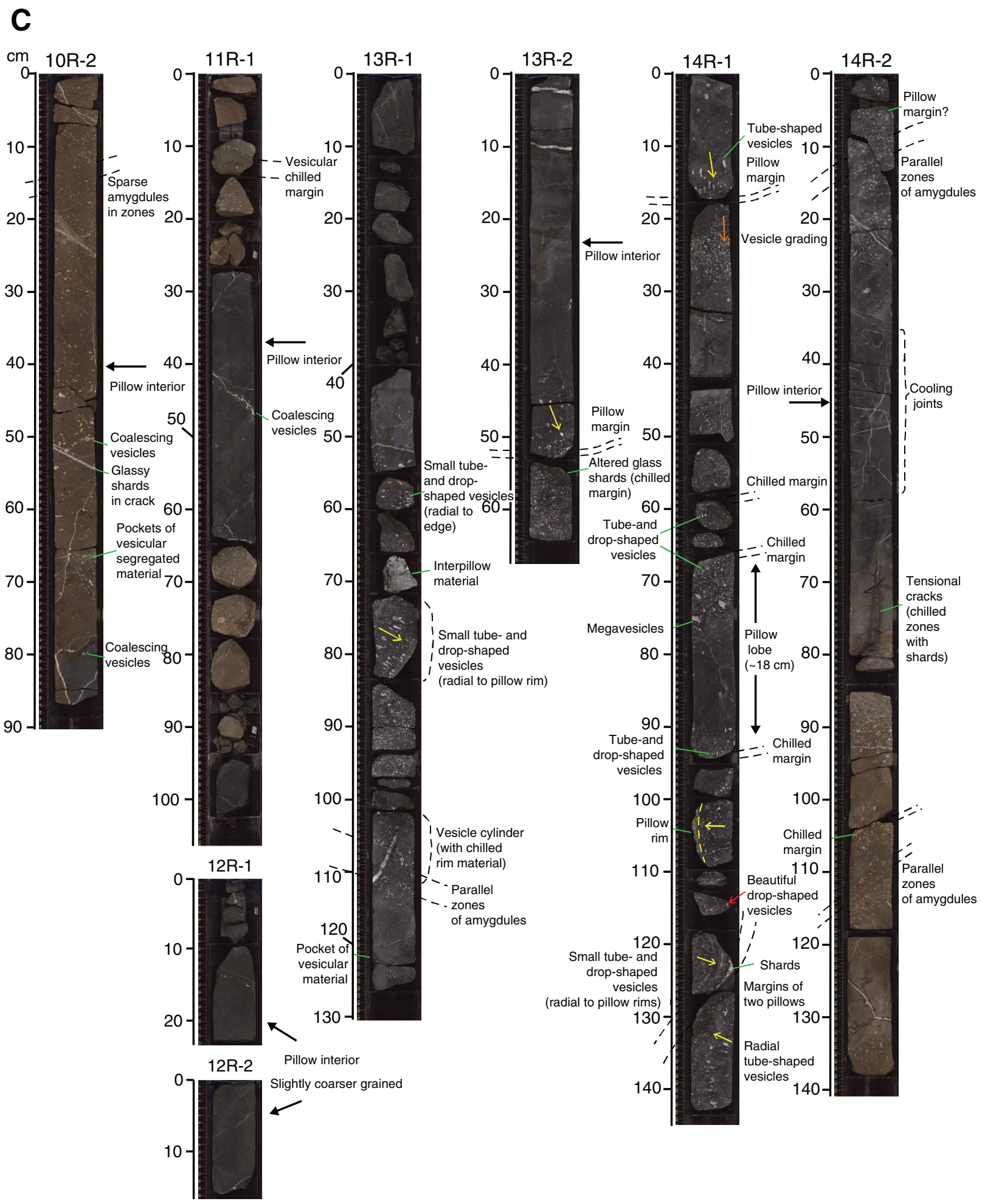


Figure F11 (continued). D. Sections 324-U1346A-14R-3 through 16R-2. Diagrammatic sketches of pillow lobes adjacent to Section 324-U1346A-16R-2 are modified after Yamagishi (1994).

D

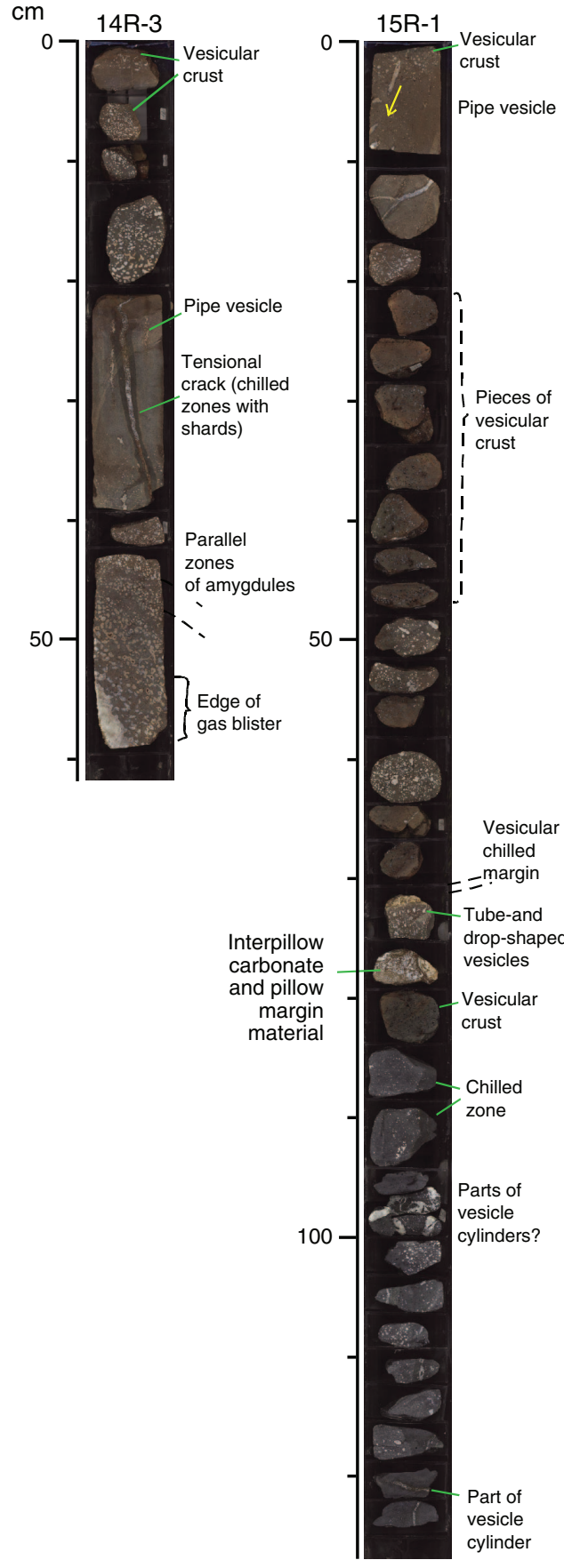

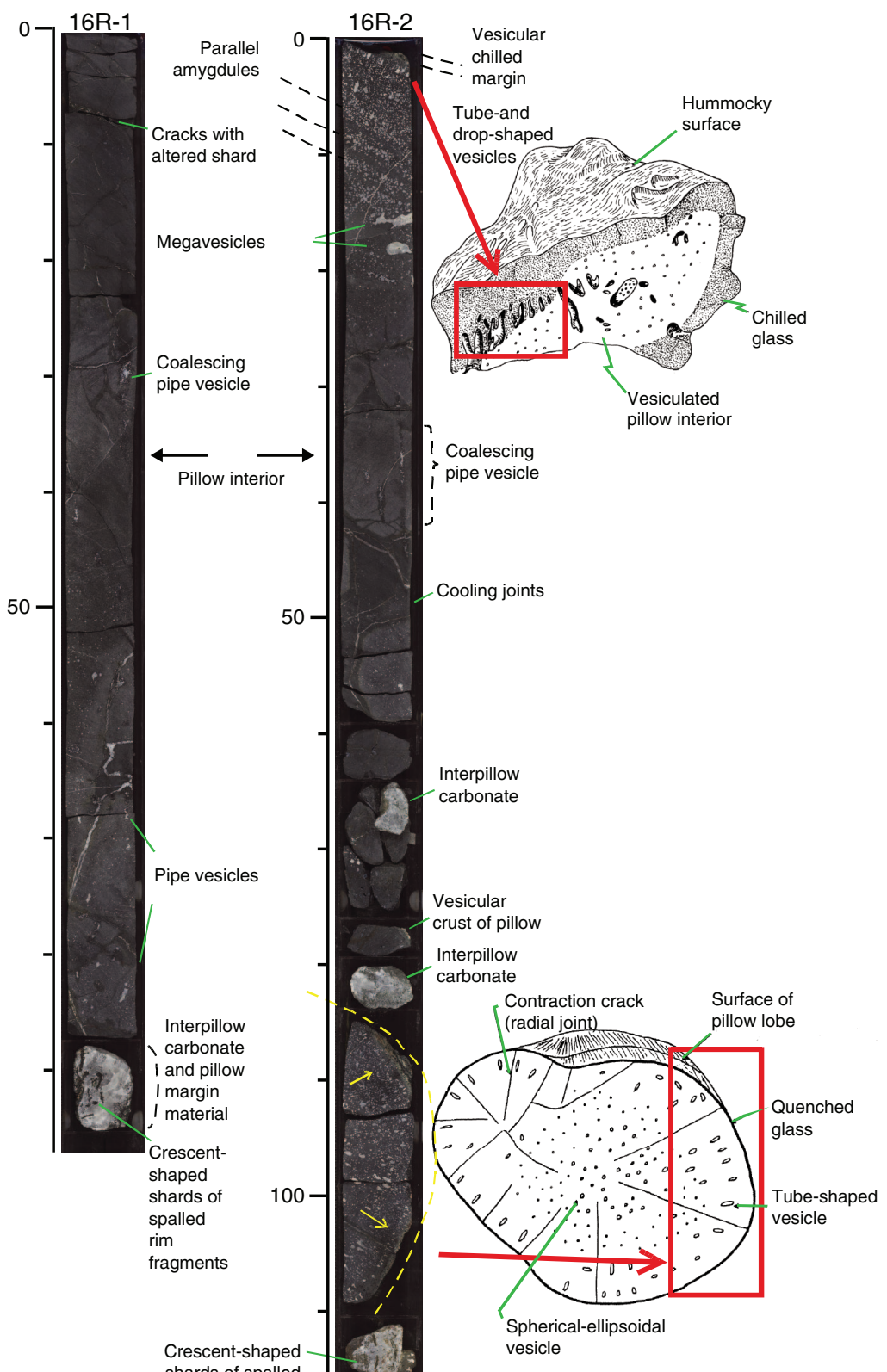


Figure F12. Vesicular basalt clast within fine-grained clayey limestone (interval 324-U1346A-4R-1, 61-76 cm; Unit II). The clayey limestone contains soft-sediment deformation features, and sediment fills some vesicles and voids in the basalt crust. The inspection of the basalt clast margin reveals broken plagioclase grains and vesicles; it lacks a chilled margin, indicating it was brittle (i.e., not molten) when it mixed with the wet sediment.

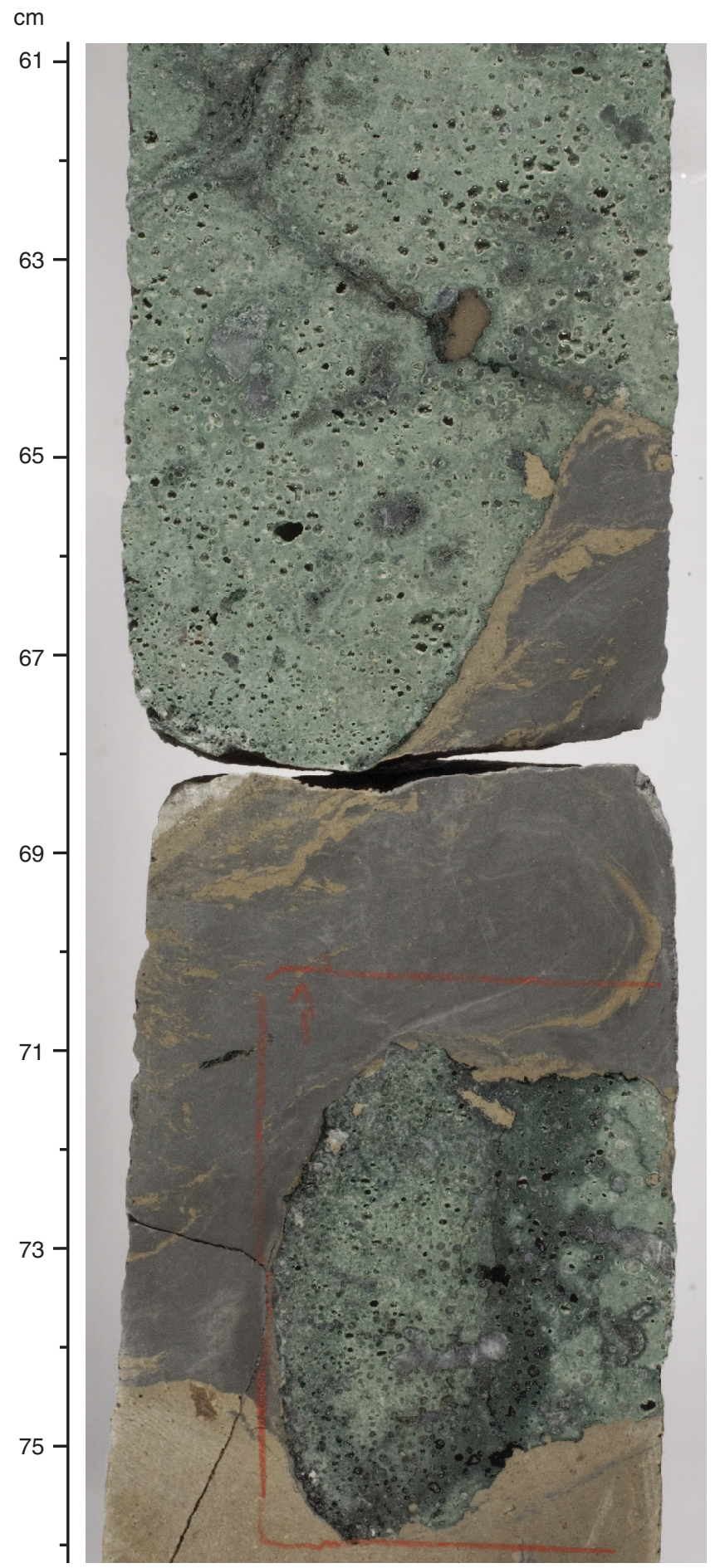


Figure F13. Vesicular basalt clast within fine-grained clayey limestone (interval 324-U1346A-4R-1, 27-35 cm; Unit II). Thin $(<1 \mathrm{~cm})$, swirled clayey layers in the limestone reveal soft-sediment deformation parallel to the margin of the basalt clast.

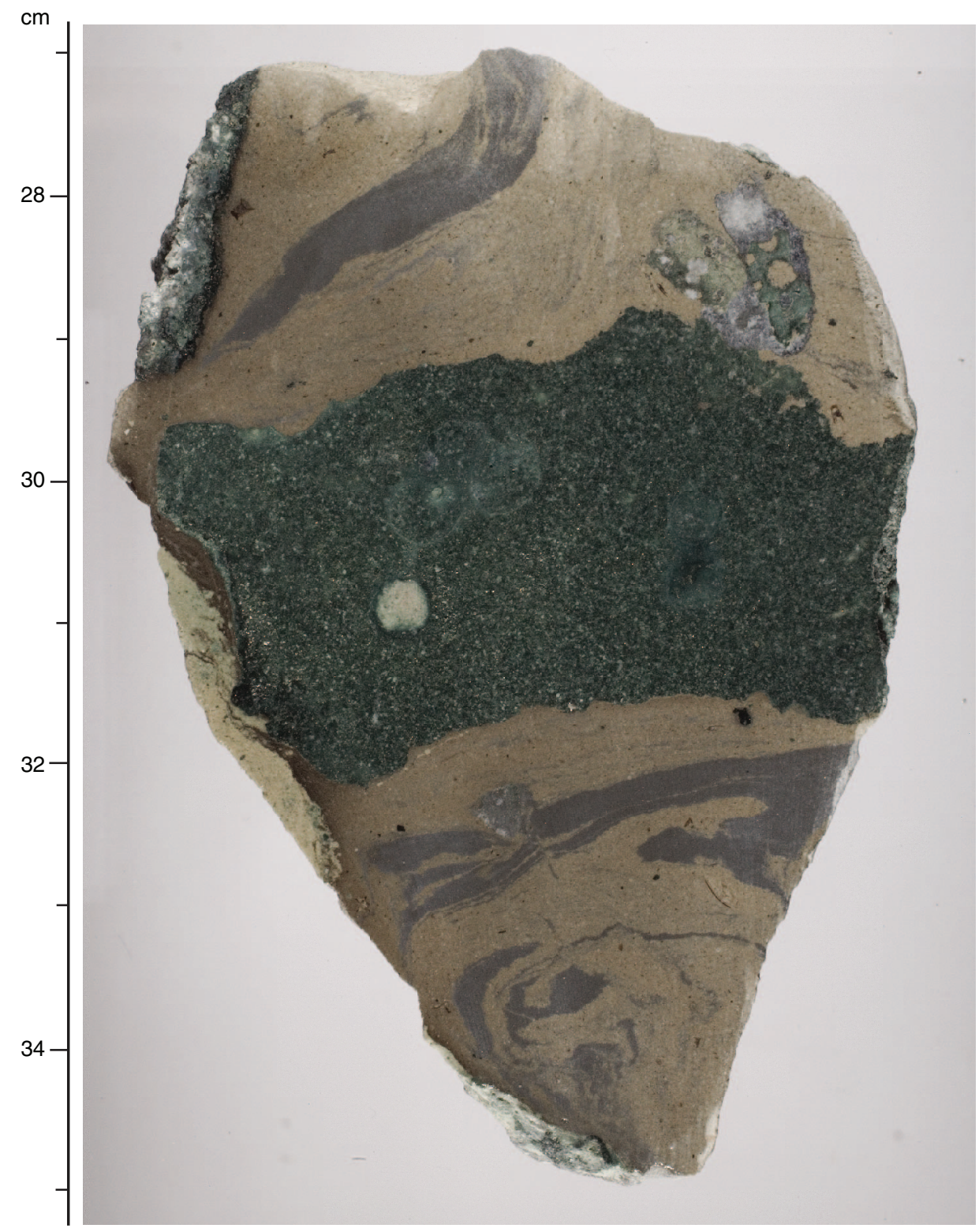


Figure F14. Idealized cross section of a pillow inflation unit showing amygdaloidal outer zones compared with a recovered example, Site U1346 (interval 324-U1346A-14R-1 [Piece 7, 66-94 cm]).

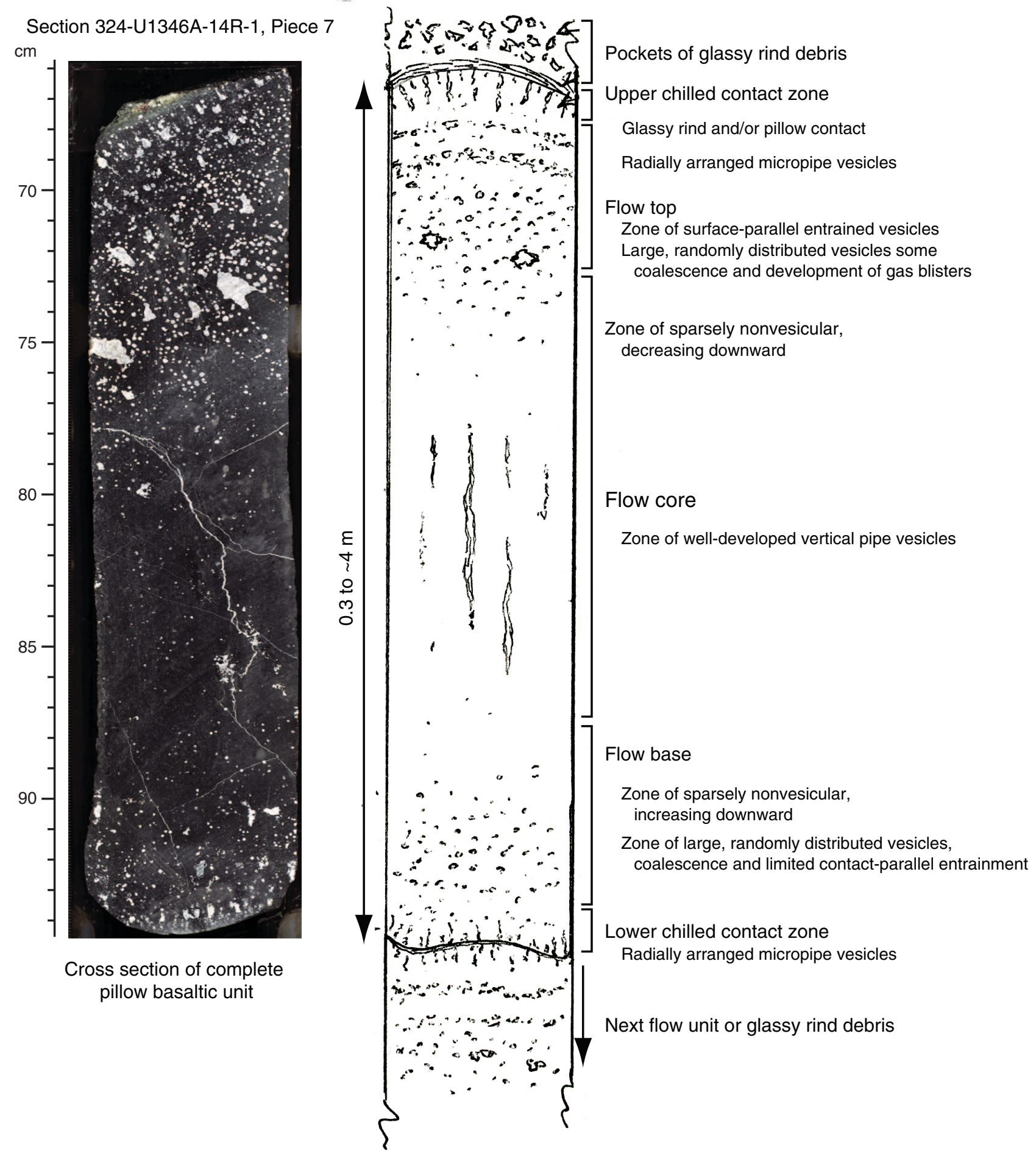


Figure F15. Idealized drawing of an igneous pillow with actual examples of different vesicular features (photo insets), Hole U1346A. A. Banded vesicles (interval 324-U1346A-14R-3, 43-59 cm). B. Pipe vesicles (interval 324U1346A-7R-3, 55-70 cm). C. Curved margin of the right side of a pillow, with radial vesicle bands near the chilled margin (Sample 324-U1346A-16R-2 [Piece 6, 85-109 cm]).

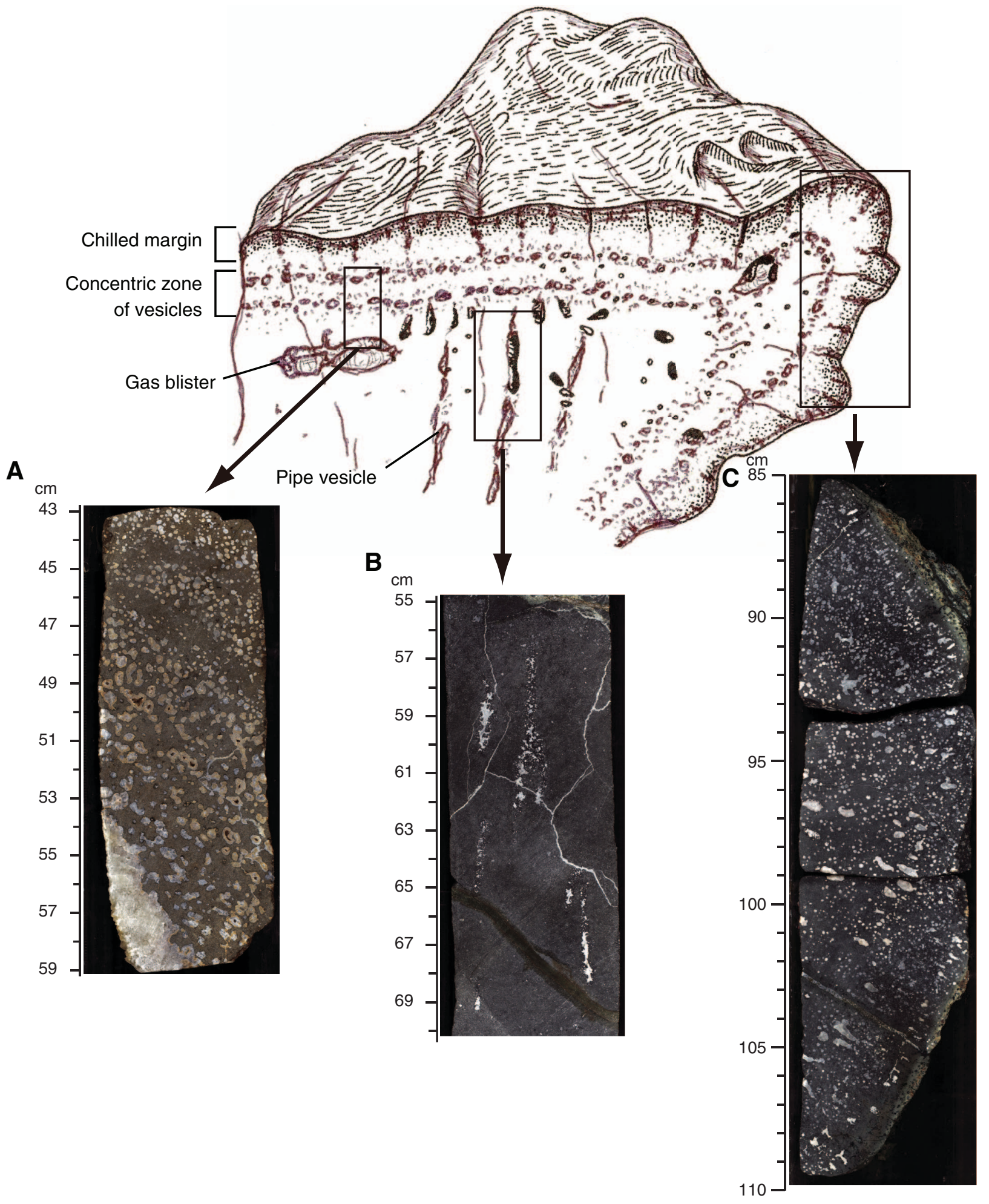


Figure F16. (A) Core image and (B) sketch of flow banding in the chilled margins of Sample 324-U1346A-8R1 (Piece 2D, 43-72 cm) with oriented elongate calcite fillings parallel to the chilled margins and filled vesicles (amygdules) as the frozen records of gas bubbles in lava.

A

$\mathrm{cm}$

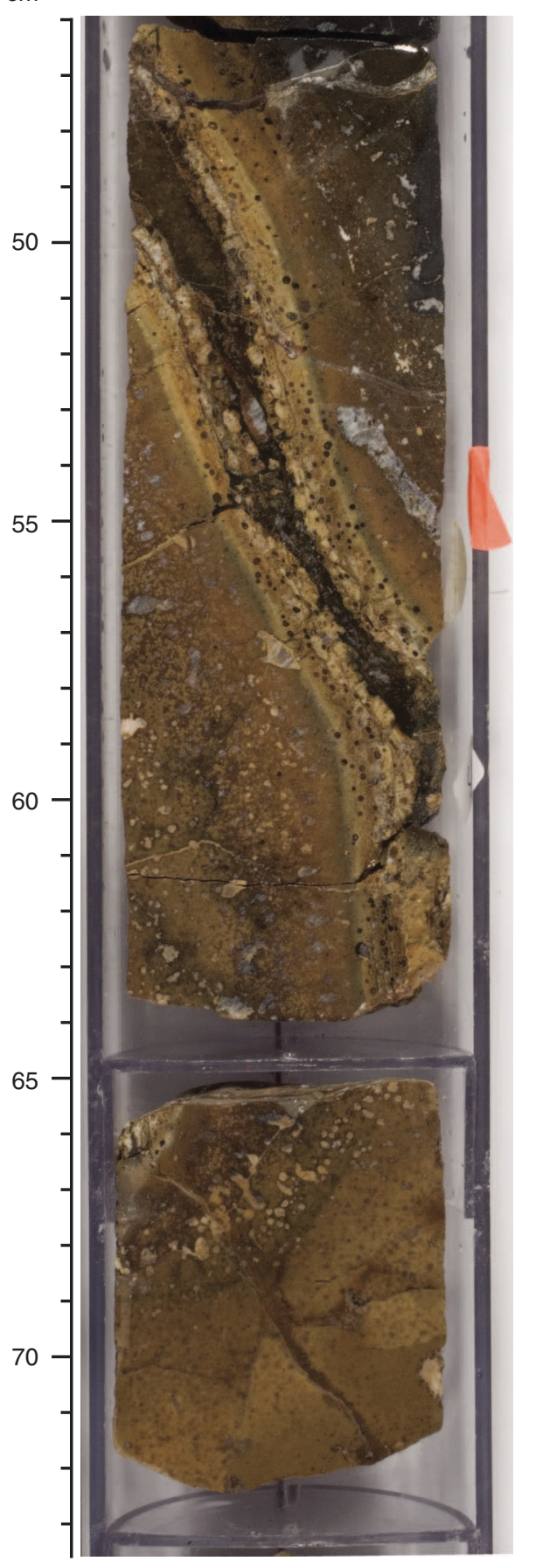

B

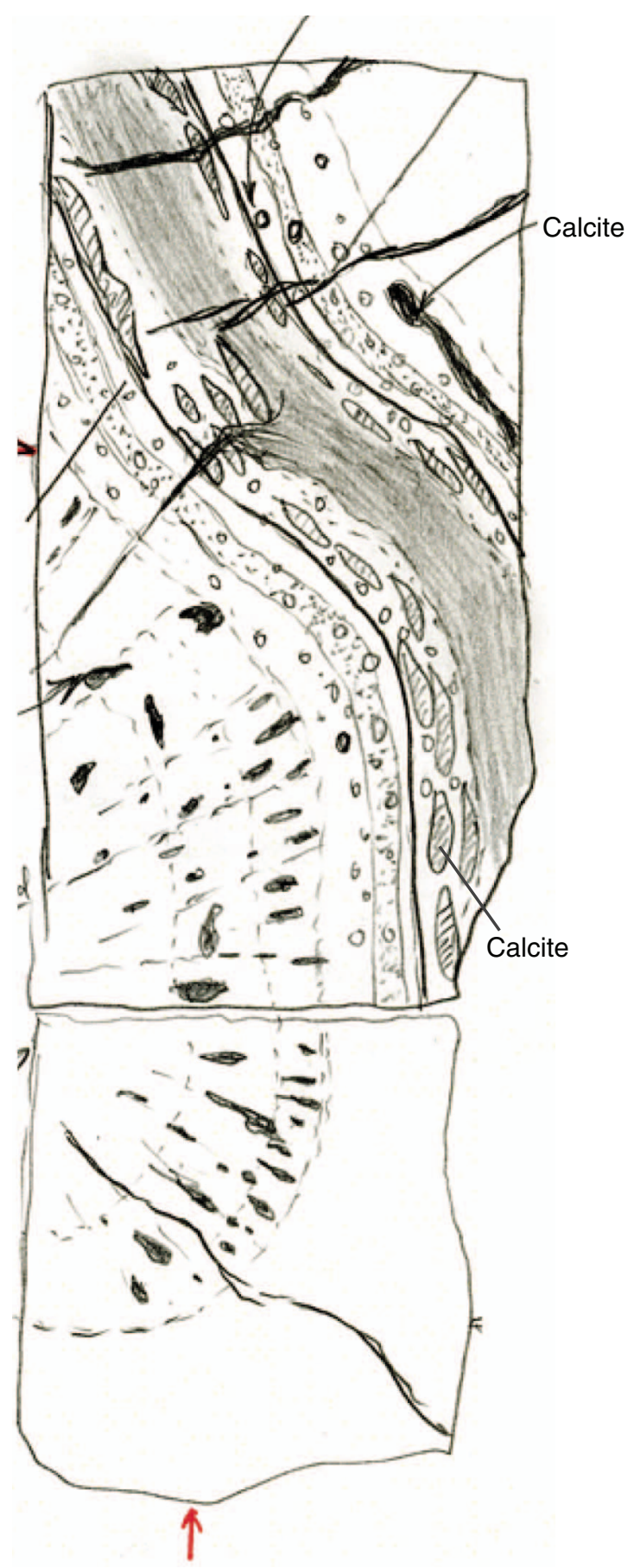


Figure F17. Photomicrograph of rare fresh glass fragment occurring in interpillow hyaloclastite amid otherwise completely altered glass, igneous minerals, and secondary material. Glass fragment with palagonite rim (orange) with very elongate acicular plagioclase crystals and a saponite pseudomorph after an equant olivine microphenocryst enclosing Cr spinel (Thin Section 28; Sample 324-U1346A-8R-1, 56-60 cm). Transmitted light.

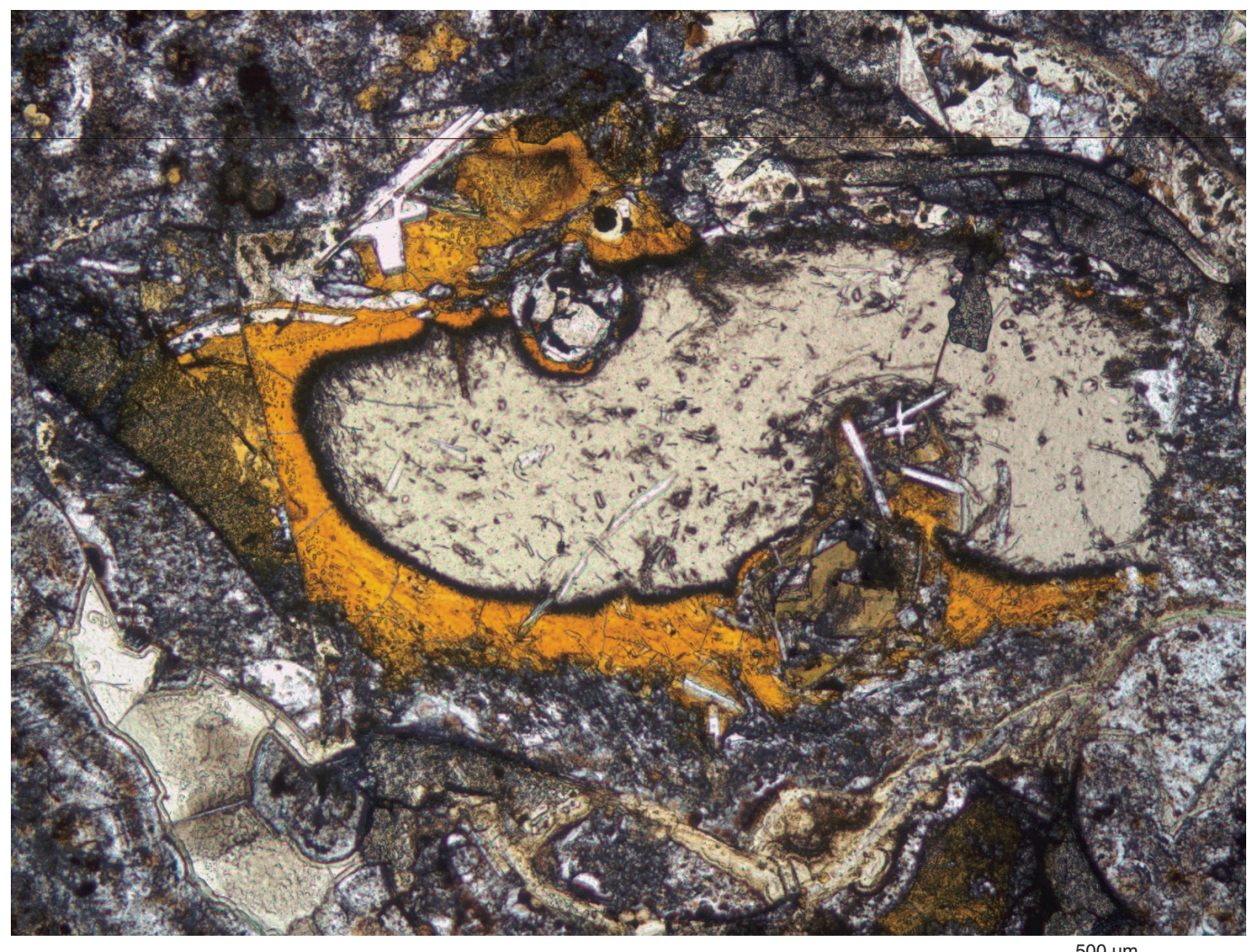

$500 \mu \mathrm{m}$ 
Figure F18. Photomicrographs of representative samples of downhole variations in groundmass and vesicularity. $\mathrm{TS}=$ thin section. All images are at the same scale.

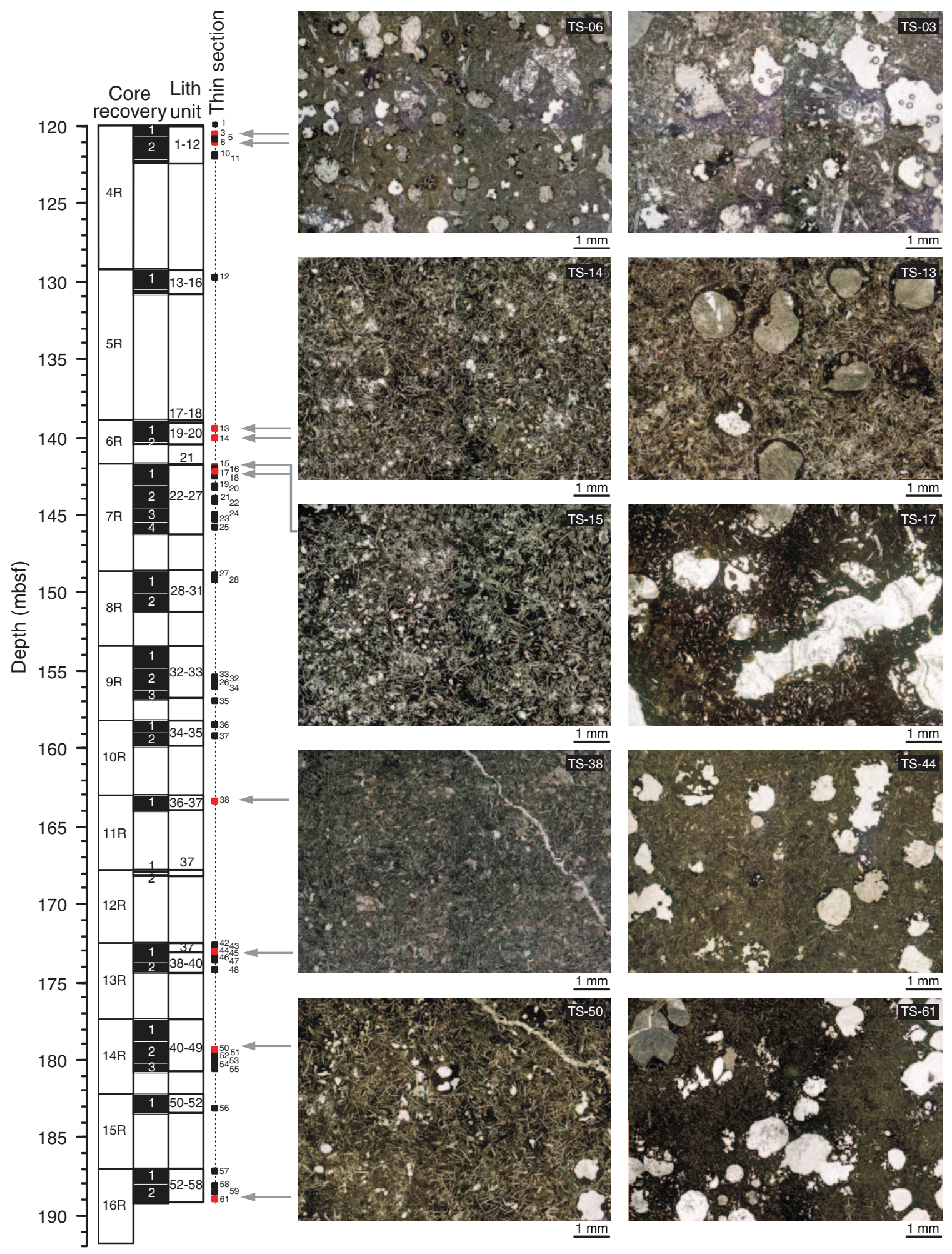


Figure F19. Photomicrograph of typical texture in a strongly altered rock. Whitish gray reflective elongate crystals are acicular plagioclase. Less reflective areas tinged in red are microcrystalline calcite. A few more bright crystals are well-crystallized calcite. Nonreflective brown areas are mainly clay minerals. Most plagioclases are pitted and have slightly grayer interiors of secondary plagioclase that are jacketed by more reflective unaltered plagioclase (Thin Section 54; Sample 324-U1346A-14R-3, 34-36 cm). Reflected light.

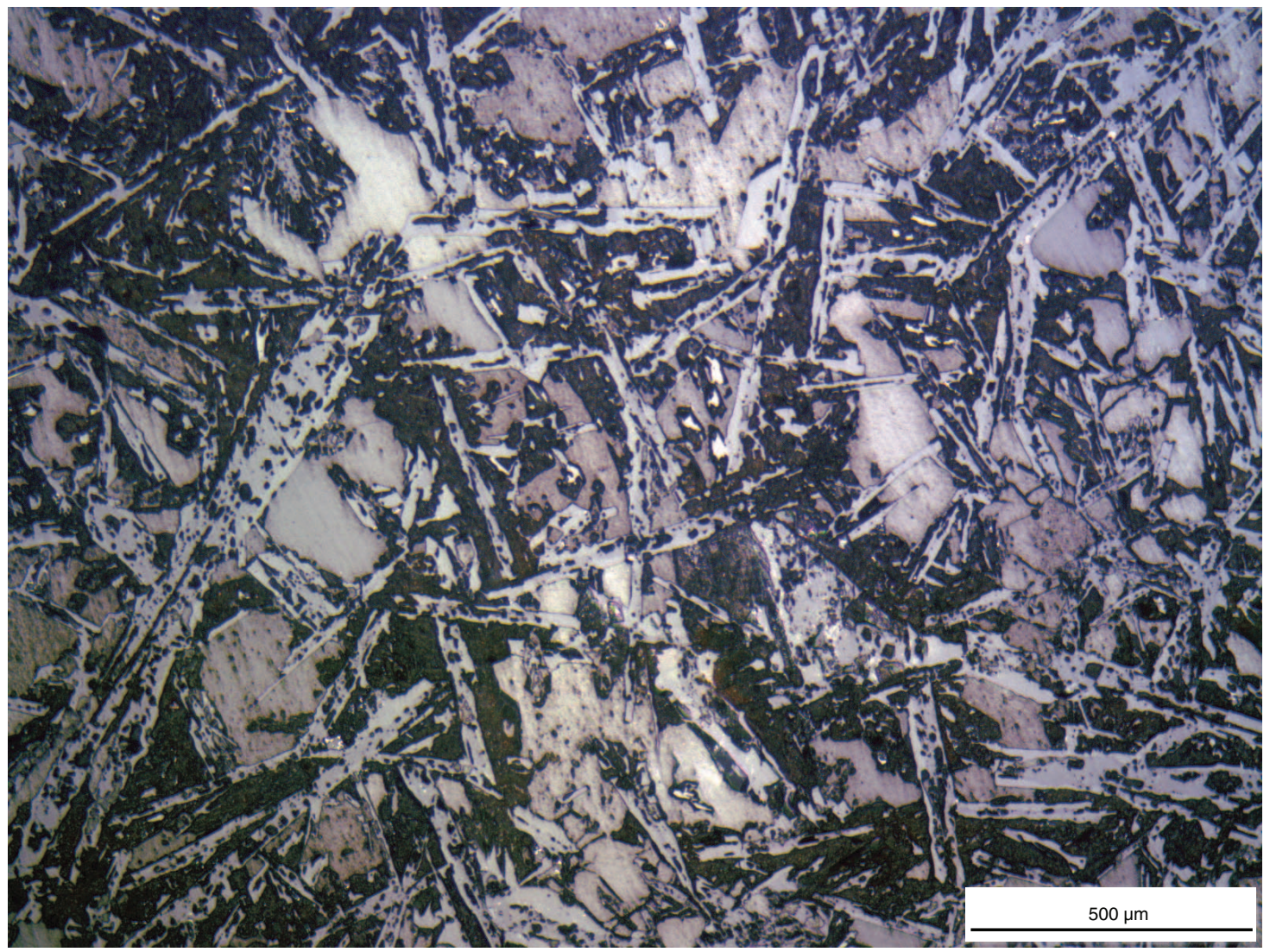


Figure F20. Photomicrographs of acicular plagioclase and clinopyroxene. A-C. Increasing lengths of acicular plagioclase with decreasing cooling rate (toward pillow interiors), with a distinctive network of interlocking plagioclase in C. (A) Thin Section 17 (Sample 324-U1346A-7R-1, 52-54 cm); (B) Thin Section 46 (Sample 324U1346A-13R-1, 85-89 cm); (C) Thin Section 14 (Sample 324-U1346A-6R-1, 115-116 cm). D. Olivine microphenocryst with enclosed $\mathrm{Cr}$ spinel that is plated with acicular plagioclase and otherwise indistinguishable in size or morphology from crystals of the surrounding matrix (Thin Section 50; Sample 324-U1346A-14R-2, 36$37 \mathrm{~cm}$ ). E. Intergrown acicular plagioclase and dendritic blades of clinopyroxene (Thin Section 38; Sample 324U1346A-11R-1, 34-35 cm). F. Large-scale replacement of material between the arms of a stellate cluster of acicular plagioclase (Thin Section 29; Sample 324-U1236A-8R-1, 86-87 cm). A-E are under transmitted light; F is under cross-polarized light.

A

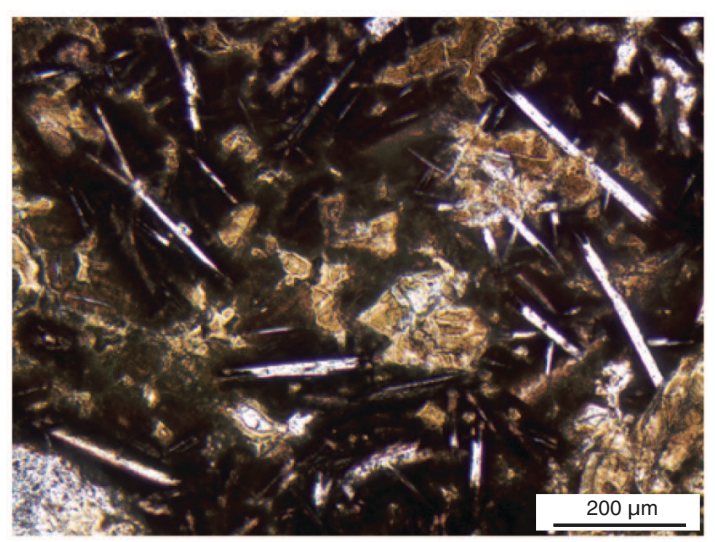

C

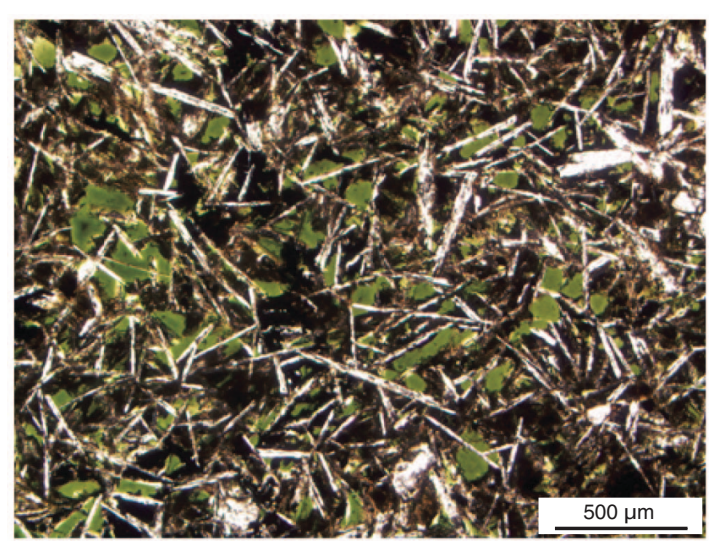

E

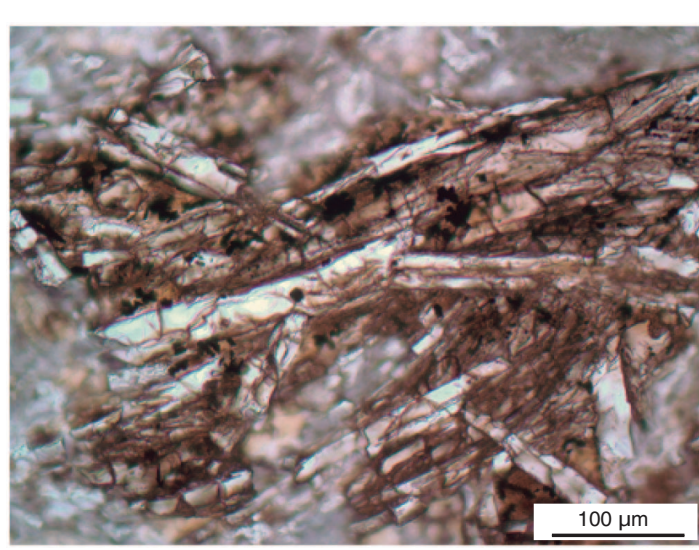

B

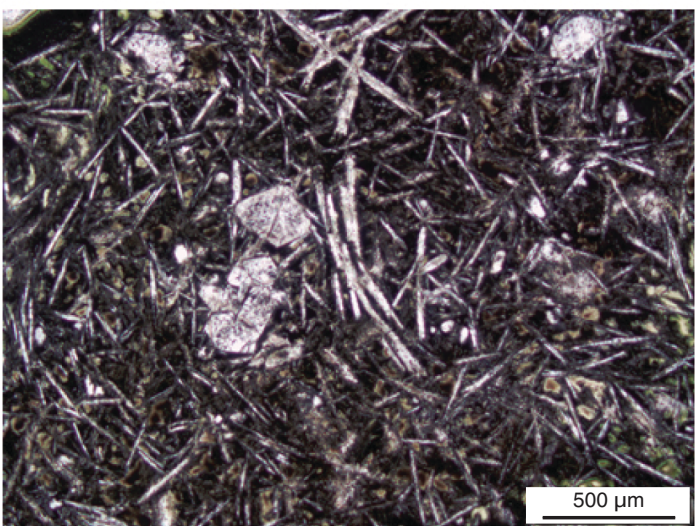

D

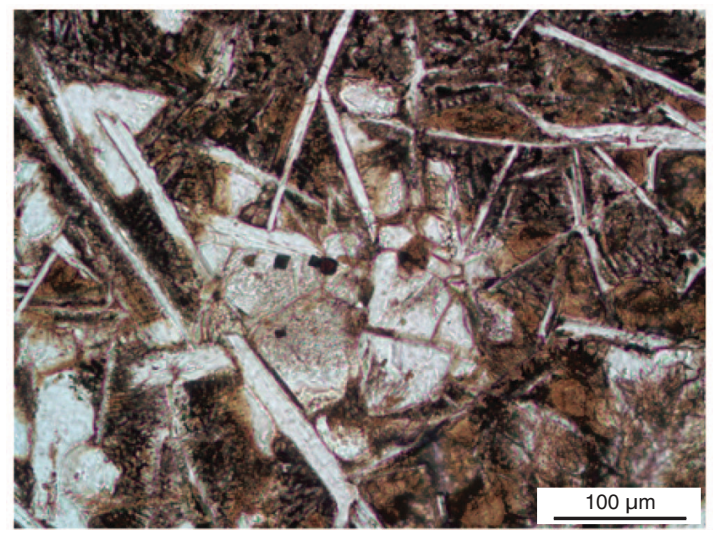

F

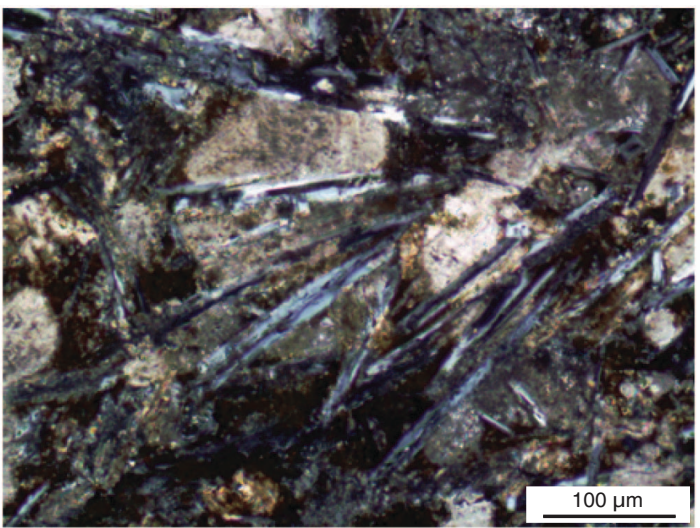


Figure F21. Photomicrographs of pseudomorphed olivine microphenocrysts. Olivine microphenocrysts in each are completely replaced by calcite, which perfectly pseudomorphs the crystal outlines and fractures and encloses $(\mathbf{C})$ round altered glass inclusions and (A, B, D) unaltered $\mathrm{Cr}$ spinel. The euhedral morphologies in these samples are easy to see because the matrix of each sample is either very fine grained or spherulitic and crystallized near a pillow margin. These olivines were all present upon eruption. Calcite in B was subsequently stained by finely disseminated Fe oxyhydroxides. (A) Thin Section 59 (Sample 324-U1346A-16R-2, 30-31 cm); (B) Thin Section 52 (Sample 324-U1346A-14R-2, 97-98 cm); (C) Thin Section 61 (Sample 324-U1346A-16R-2, 85-88 cm); (D) Thin Section 46 (Sample 324-U1346A-13R-1, 85-88 cm). Transmitted light.
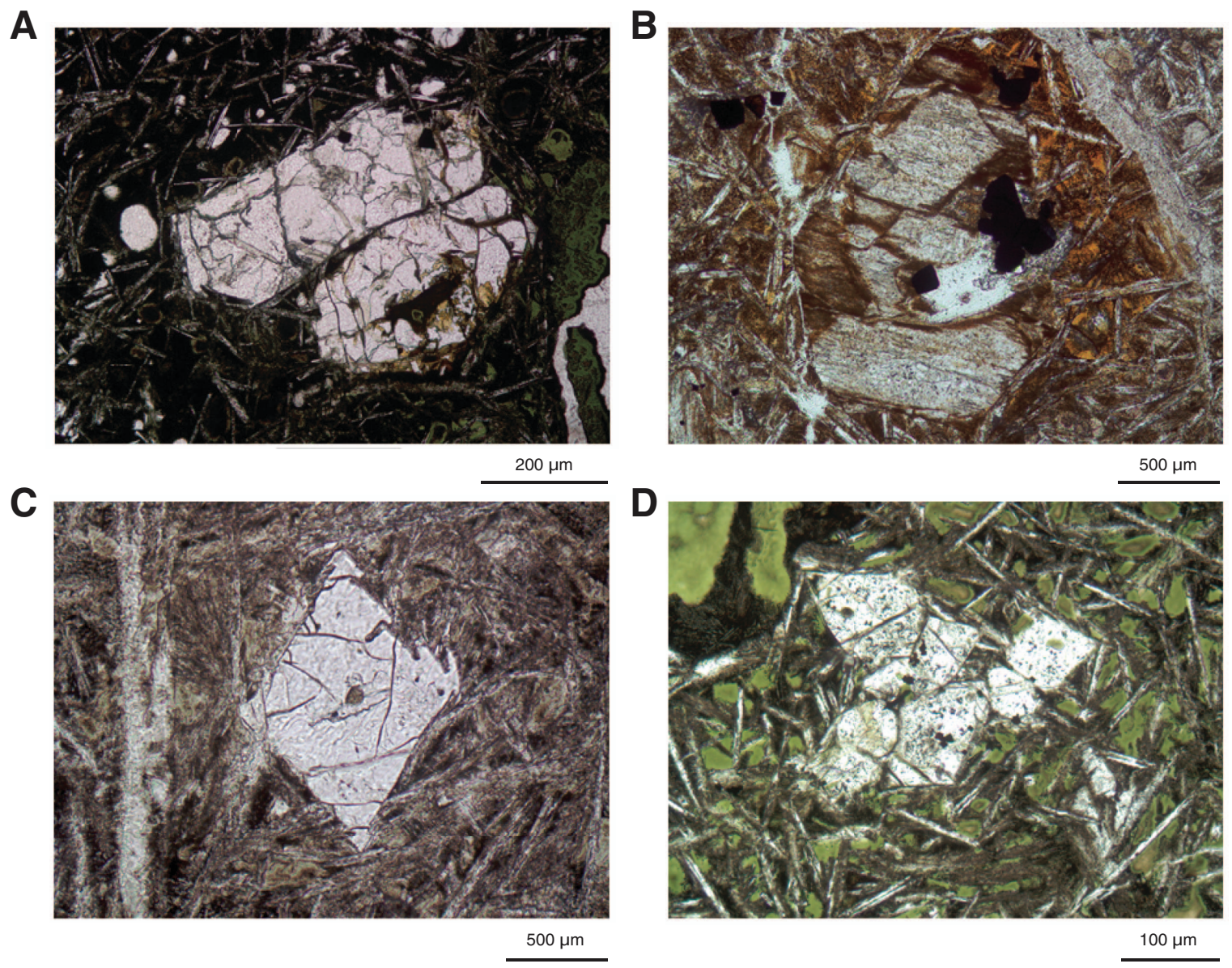
Figure F22. Photomicrographs of plagioclase and clinopyroxene microphenocrysts. A, B. Plagioclase glomerocrysts from volcanic breccia in Unit II (Thin Section 6; Sample 324-U1346A-4R-2, 23-26 cm). C. Small tabular plagioclase microphenocryst in basaltic pillow from Unit V (Thin Section 51; Sample 324-U1346A-14R-2, 66$70 \mathrm{~cm}$ ). D. Plagioclase microphenocryst, with an irregular edge, enclosing several plagioclase microlites (Thin Section 42; Sample 324-U1346A-13R-1, 15-19 cm). E, F. Groundmass intergrowth of acicular clinopyroxene and anhedral dendrites or blades of clinopyroxene. View in $\mathrm{F}$ is rotated slightly to enhance color contrast (Thin Section 50; Sample 324-U1346A-14R-2, 36-37 cm). A, B, and F are under cross-polarized light; C, D, and E are under transmitted light.

A

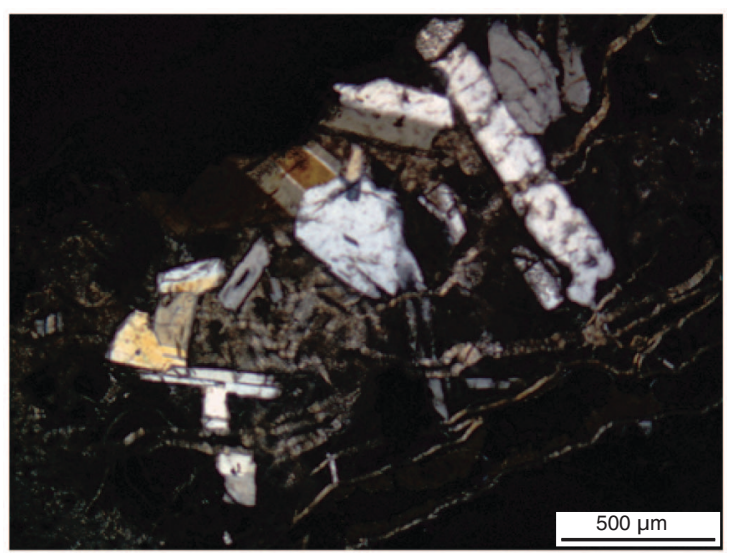

C

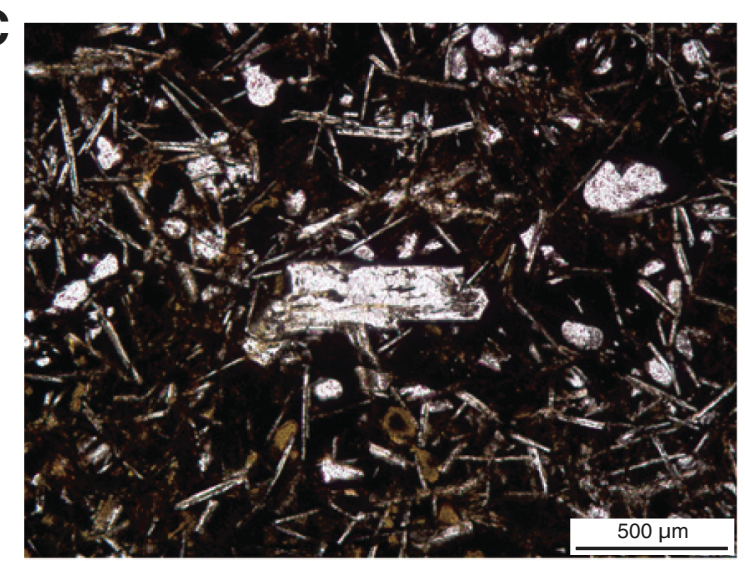

E

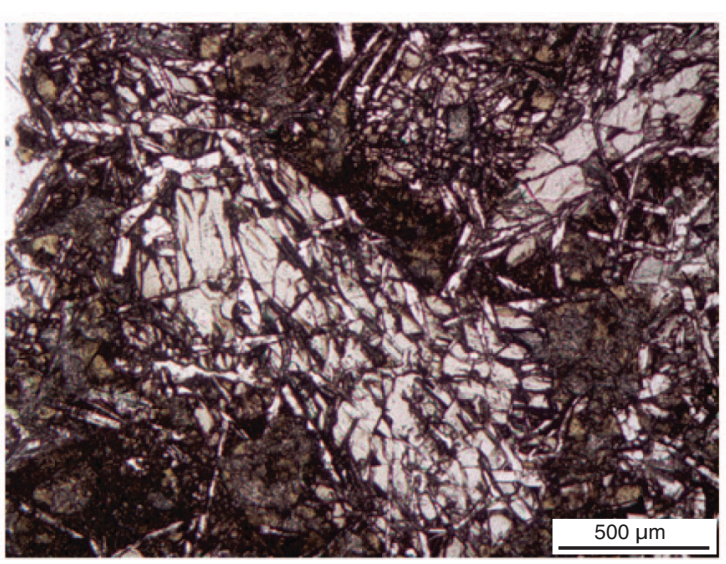

B
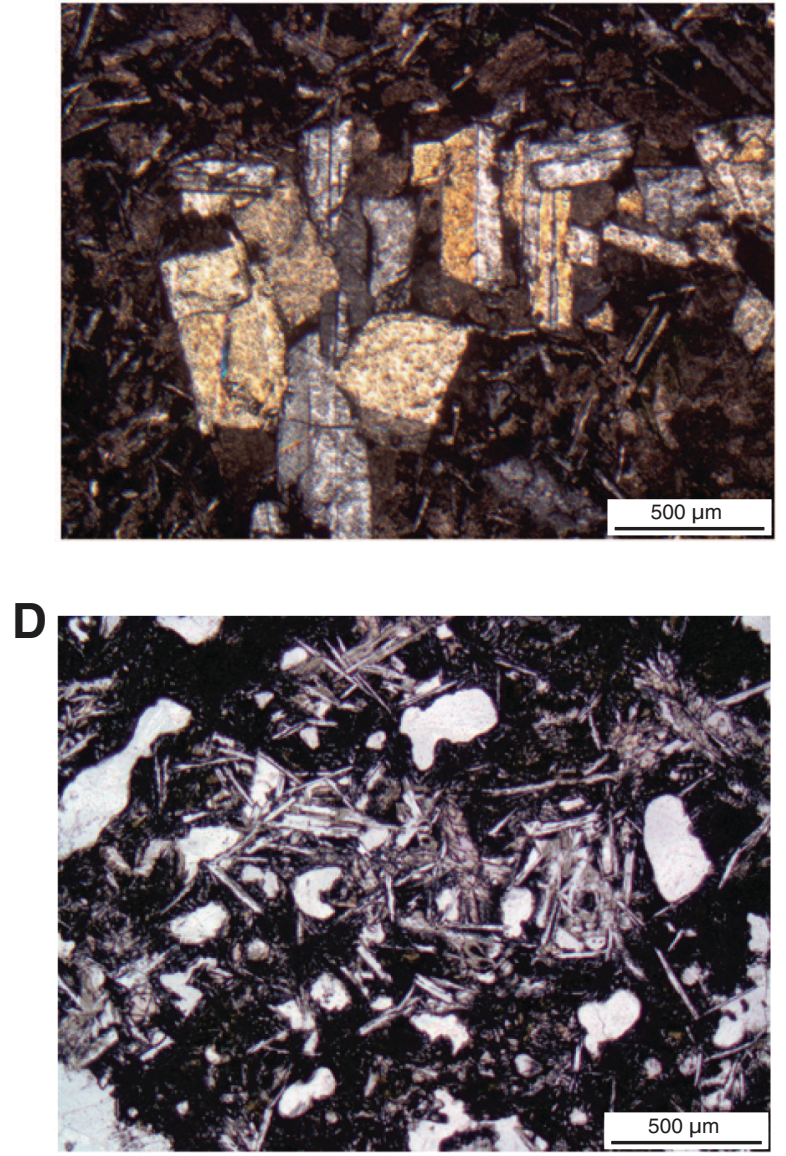

$F$

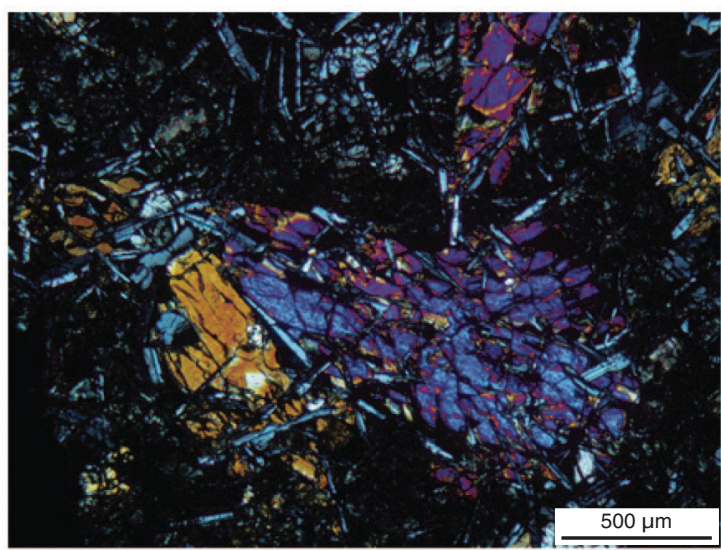


Figure F23. A-D. Photomicrographs of olivine microphenocrysts pseudomorphed by calcite but retaining round glass inclusions, now altered to clays (Thin Section 61; Sample 324-U1346A-16R-2, 85-88 cm). Transmitted light.
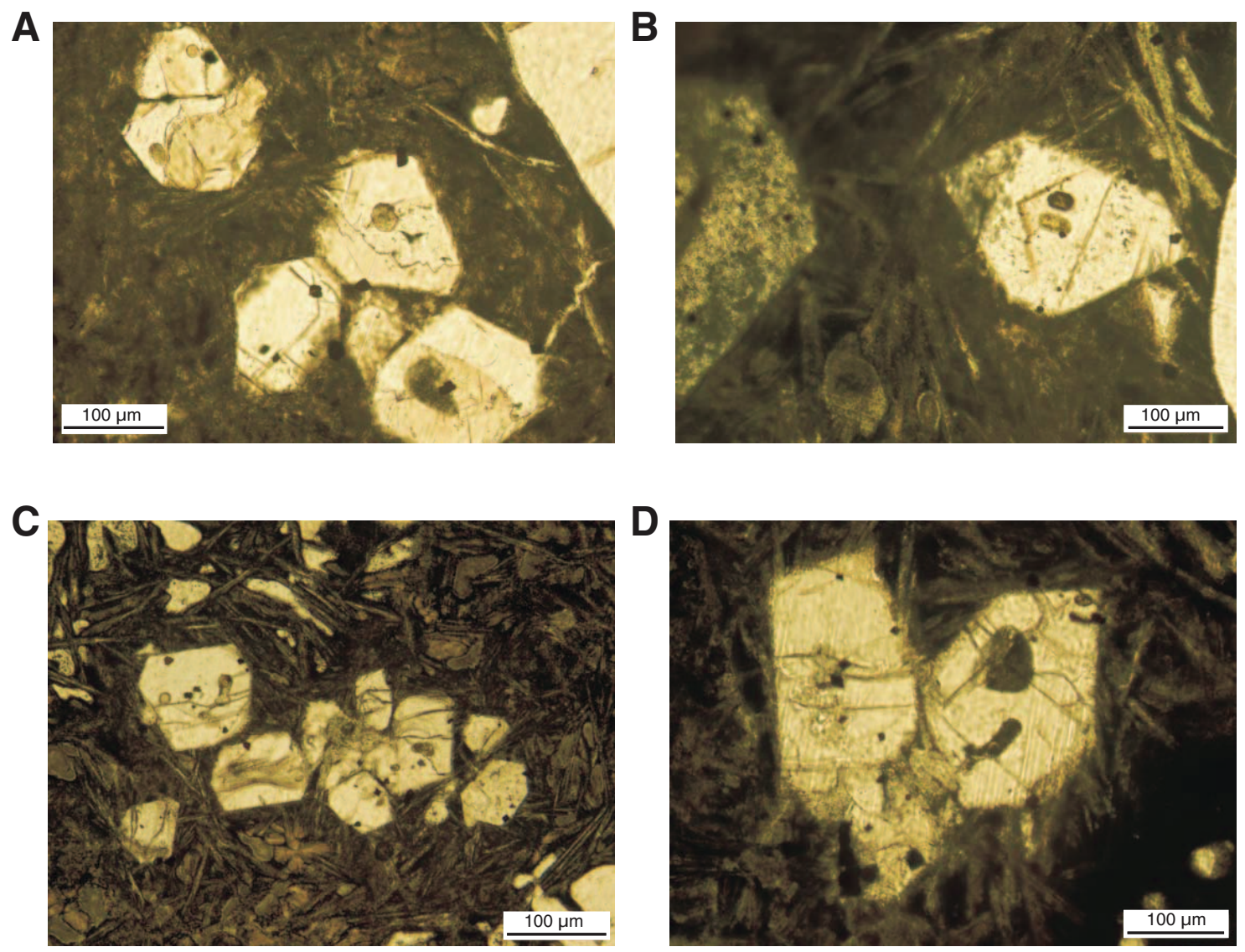
Figure F24. Photomicrographs of spinel. A. Small Cr spinel enclosed by or attached to olivine microphenocrysts, now pseudomorphed by clays (Thin Section 28; Sample 324-U1346A-8R-1, 56-60 cm). B. Small Cr spinel enclosed by or attached to olivine microphenocrysts, pseudomorphed by calcite. Engaging the conoscope to increase light reveals that spinel is dark brown (Thin Section 23; Sample 324-U1346A-7R-3, 67-70 cm). C. Clumped spinel (Thin Section 47; Sample 324-U1346A-13R-1, 102-105 cm). D. Spinel occurring within olivine (Thin Section 28; Sample 324-U1346A-8R-1, 28-29 cm). E. Thin Section 47 (Sample 324U1346A-13R-1, 102-105 cm). F. Largest spinel in the core attached to an olivine pseudomorph on its right (Thin Section 36; Sample 324-U1346A-10R-1, 24-25 cm). A-C are under transmitted light; D-F are under reflected light.
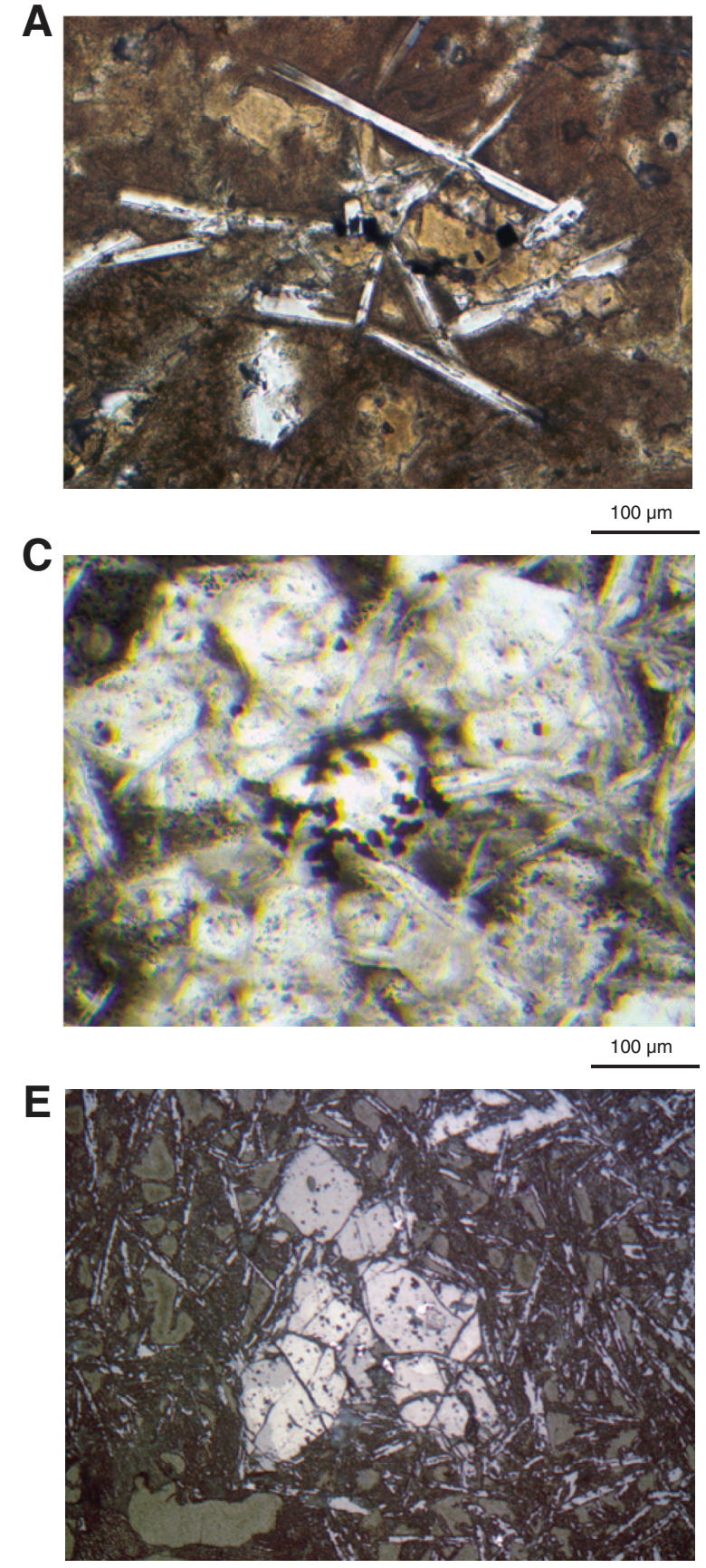

$100 \mu \mathrm{m}$
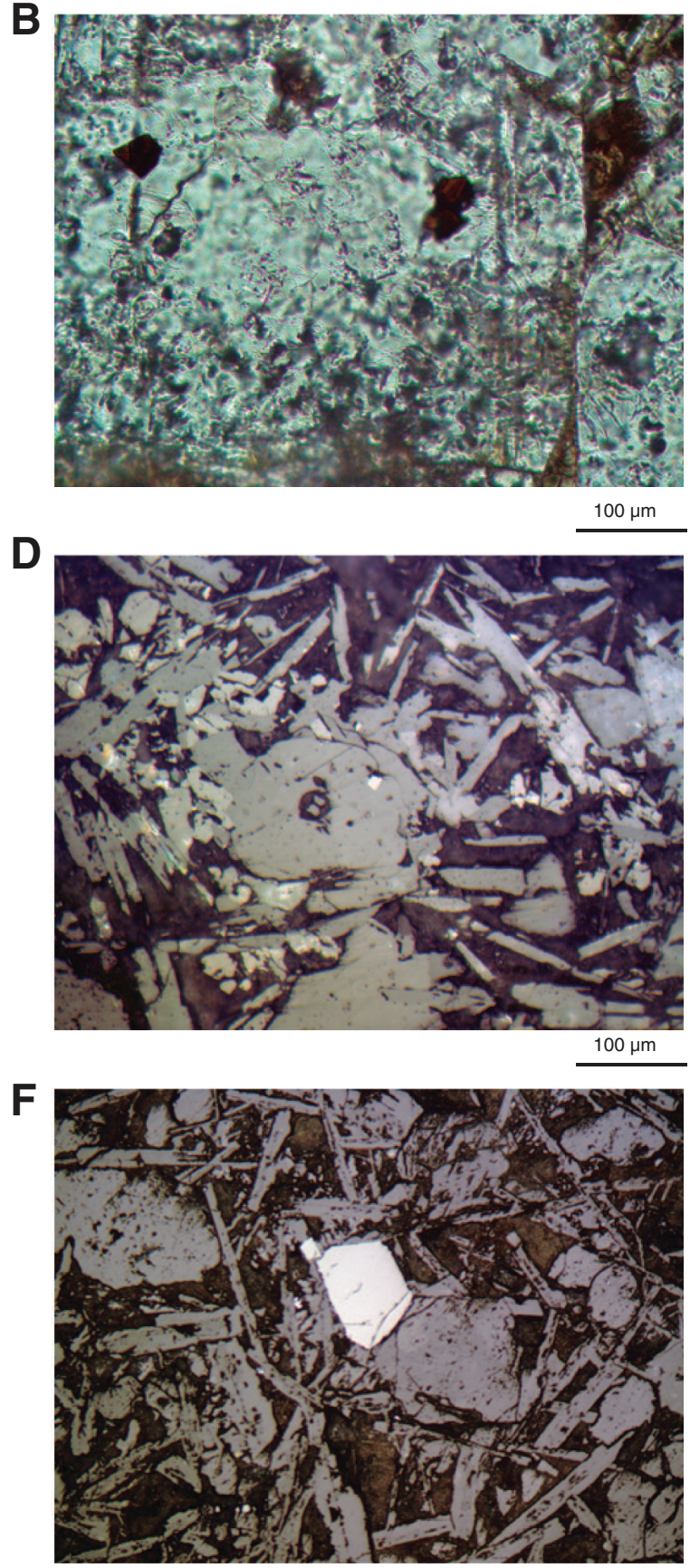

$200 \mu \mathrm{m}$ 
Figure F25. Photomicrographs of vesicles. A. Clay-lined vesicle in a near-glassy spherulitic zone but not a segregation vesicle (Thin Section 6; Sample 324-U1346A-4R-2, 23-26 cm). B. Segregation vesicle (Thin Section $53 ; 324-U 1346 A-14 R-2,107-108 \mathrm{~cm})$. C, D. In C, the segregation vesicle is sliced laterally through a meniscus that did not intersect the vesicle. The slice shows an intergrowth of needles of clinopyroxene and tiny titanomagnetite crystals between the needles. $\mathrm{D}$ is the same sample, rotated and under cross-polarized light, showing that bundles of the clinopyroxene needles have common extinction angles and thus are dendritic intergrowths (Thin Section 50; Sample 324-U1346A-14R-3, 36-37 cm). E. Segregation vesicle with a portion of another meniscus and tiny skeletal titanomagnetite crystals randomly dispersed between clinopyroxene needles (Thin Section 37; Sample 324-U1346A-10R-2, 16-18 cm). F. Segregation vesicle showing a partial meniscus. The principal vesicle bubble at the upper left is lined with clays and calcite. The meniscus again consists of dendritic clinopyroxene and intergrown titanomagnetite, but in this case it is itself vesicular. As the main vesicle shrank during cooling, drawing melt into the original bubble, new bubbles in turn nucleated and grew within the meniscus. The newer vesicles are now filled with green clay (Thin Section 47; Sample 324-U1346A-13R-1, 102$105 \mathrm{~cm})$. A-C and F are under transmitted light; D is under cross-polarized light; E is under reflected light. (Figure shown on next page.) 
Figure F25 (continued). (Caption shown on previous page.)

A

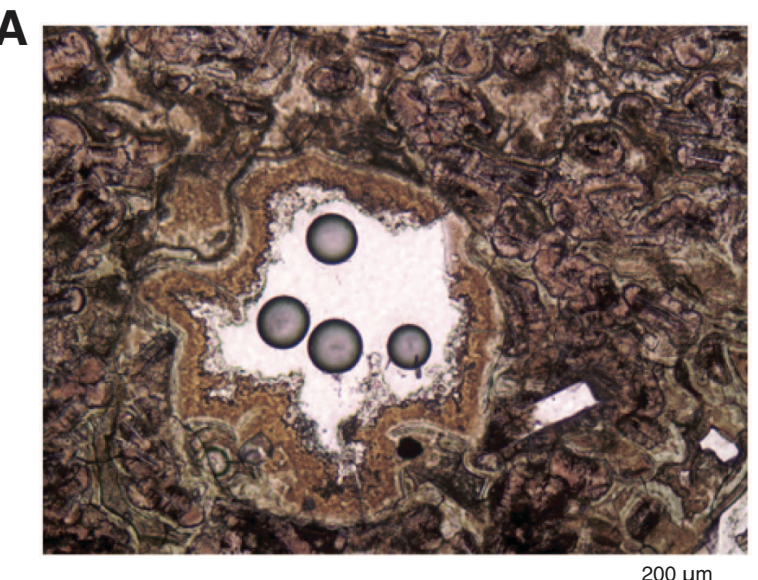

c

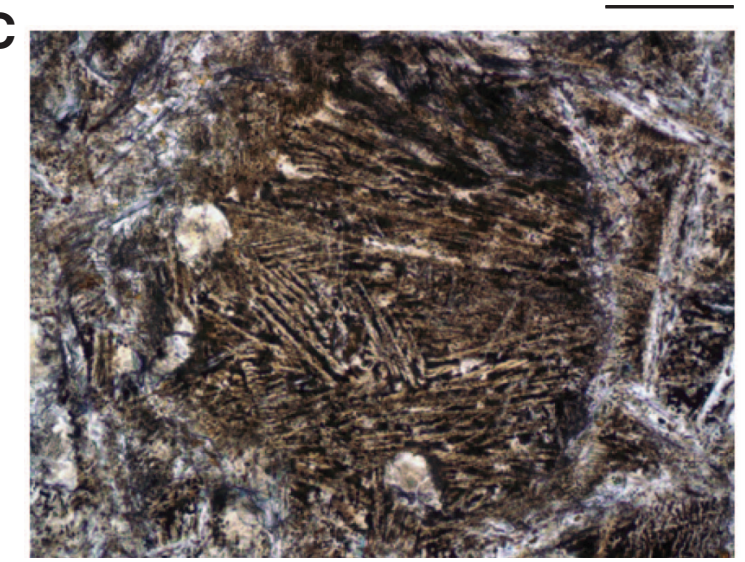

E

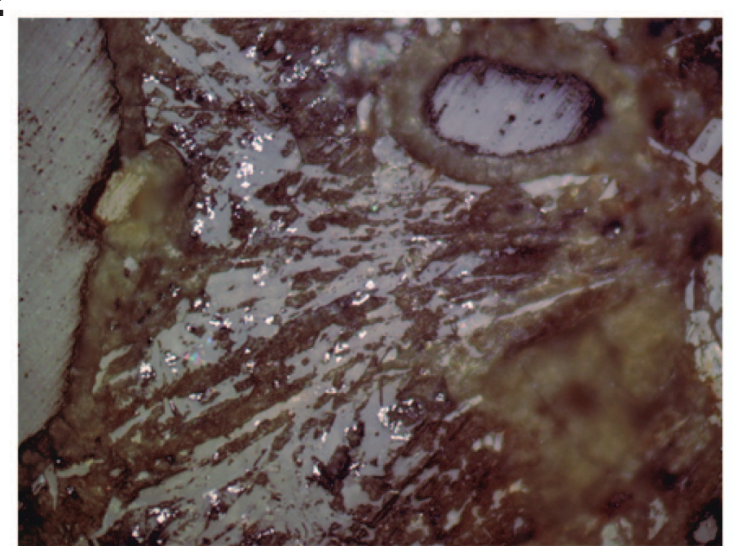

B

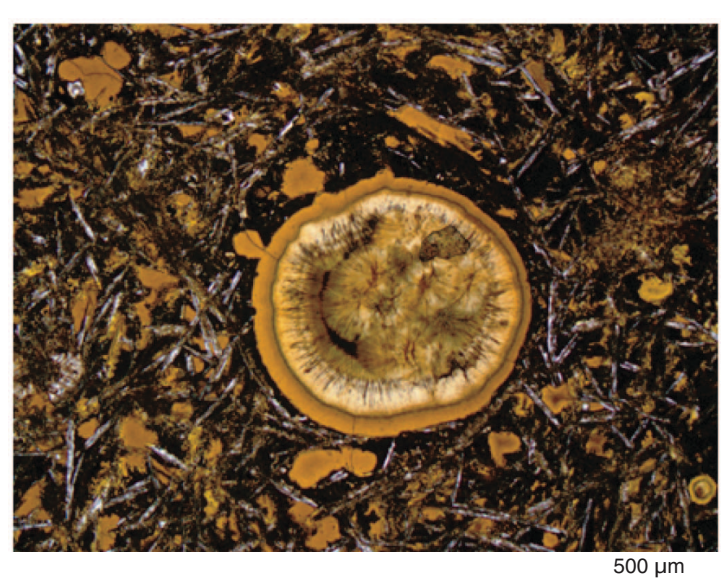

D

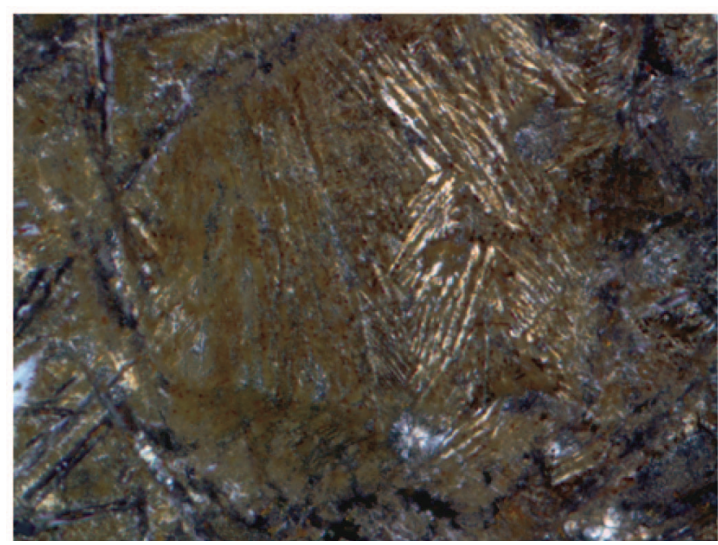

$100 \mu \mathrm{m}$

$\mathbf{F}$

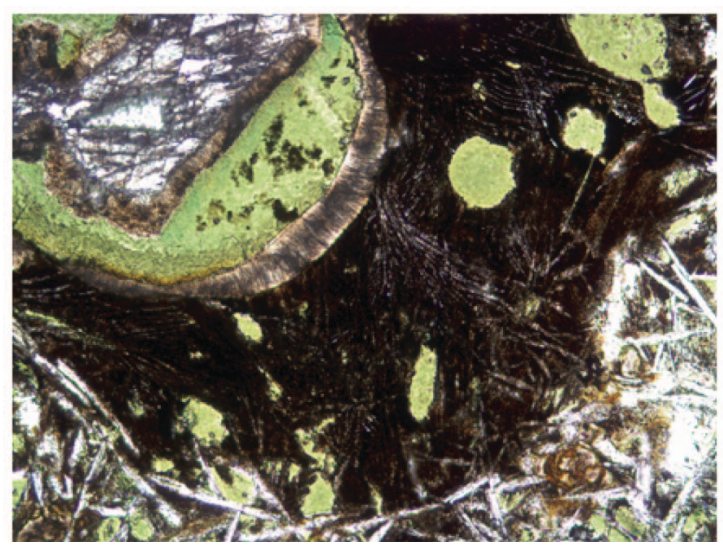

$100 \mu \mathrm{m}$

$200 \mu \mathrm{m}$ 
Figure F26. Stratigraphy of downhole alteration, Hole U1346A.

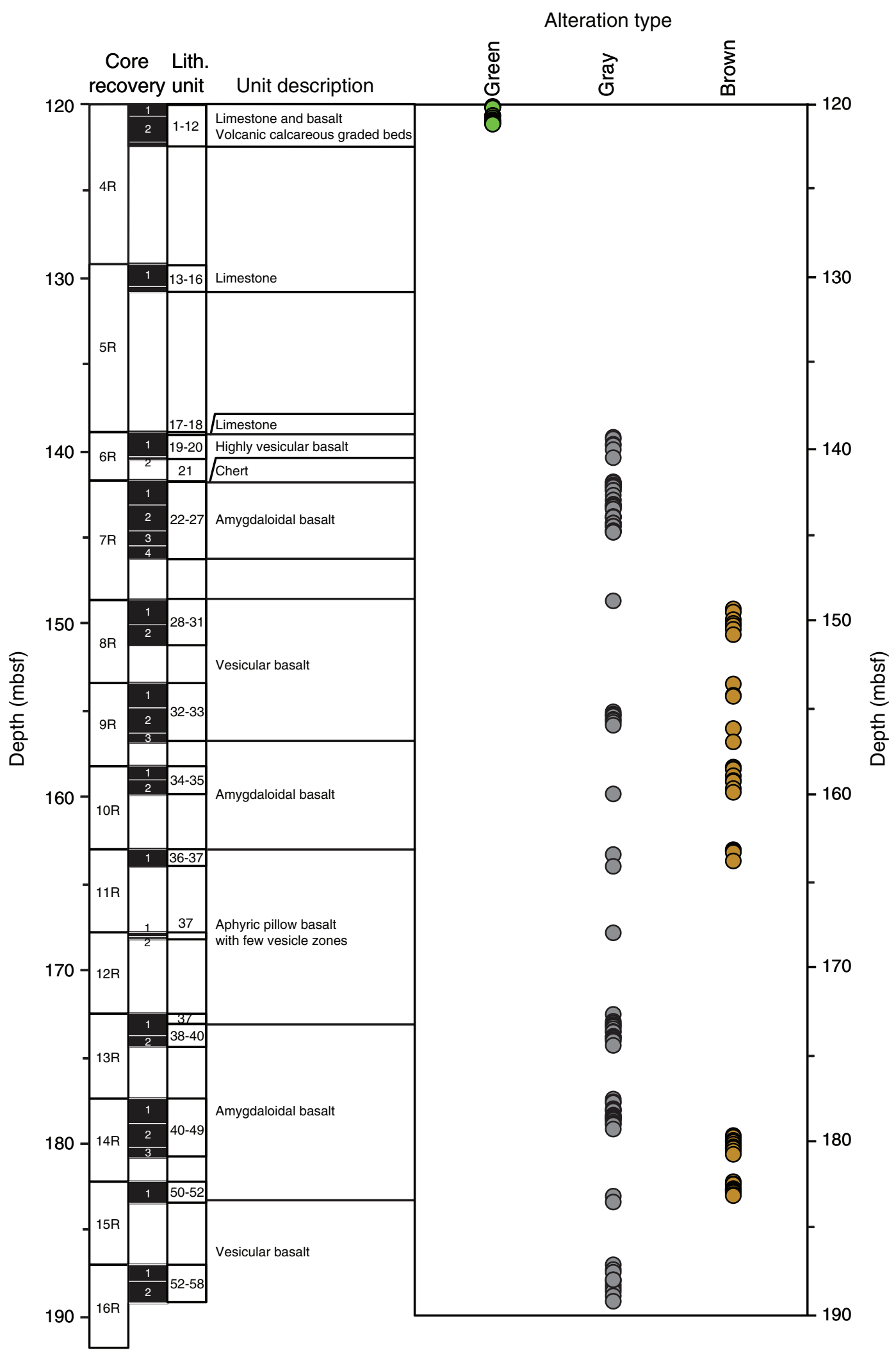


Figure F27. Photomicrographs of sulfides in basaltic rocks, Hole U1346A. A. Blocky pyrite (bright) and chalcopyrite (gold) in a vesicle filled with calcite. B. Blocky marcasite (multicolored, in partially polarized reflected light) and uniformly colored porous pyrite. C. Vesicle filling of blocky pyrite (golden) and irregularly shaped clays later cemented by calcite. D. Fine-grained pyrite in a vesicle. E. Two forms of pyrite, blocky and porous, in acicular crystalline matrix at the edge of a vesicle. F. Mainly porous sulfide interpenetrating acicular basalt next to a vesicle on the left. A-D. Thin Section 3 (Sample 324-U1346A-4R-1, 48-51 cm). E. Thin Section 6 (Sample 324-U1346A-4R-2, 23-26 cm). F. Thin Section 13 (Sample 324-U1346A-6R-1, 53-55 cm). All photomicrographs are under reflected light; $\mathrm{C}$ is under simultaneous transmitted light.
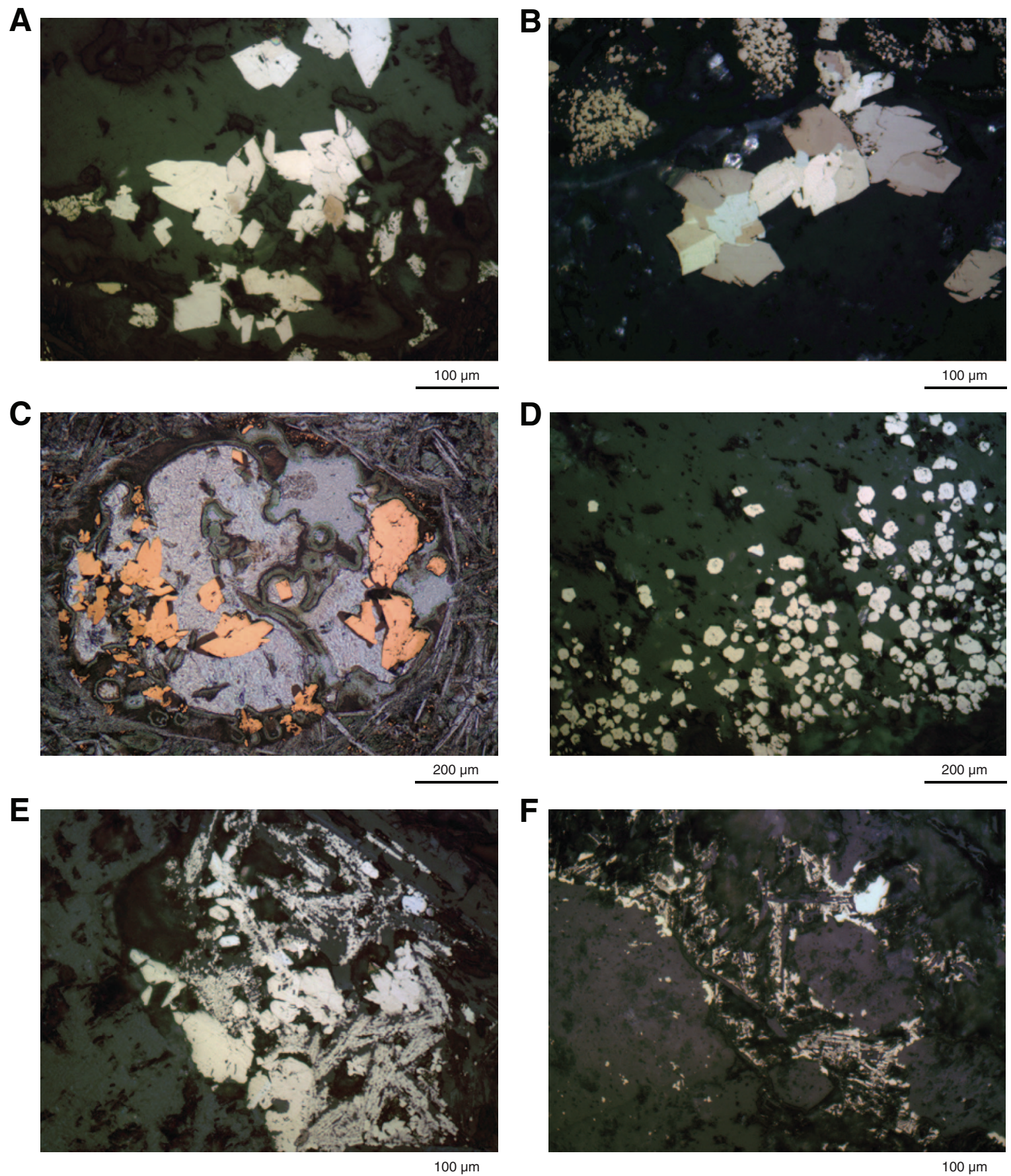

$100 \mu \mathrm{m}$ 
Figure F28. Photomicrograph of clinopyroxenes nearly completely replaced by calcite and surrounded by brown clays replacing glass (Sample 324-U1346A-7R-1, 52-54 cm). Cross-polarized light.

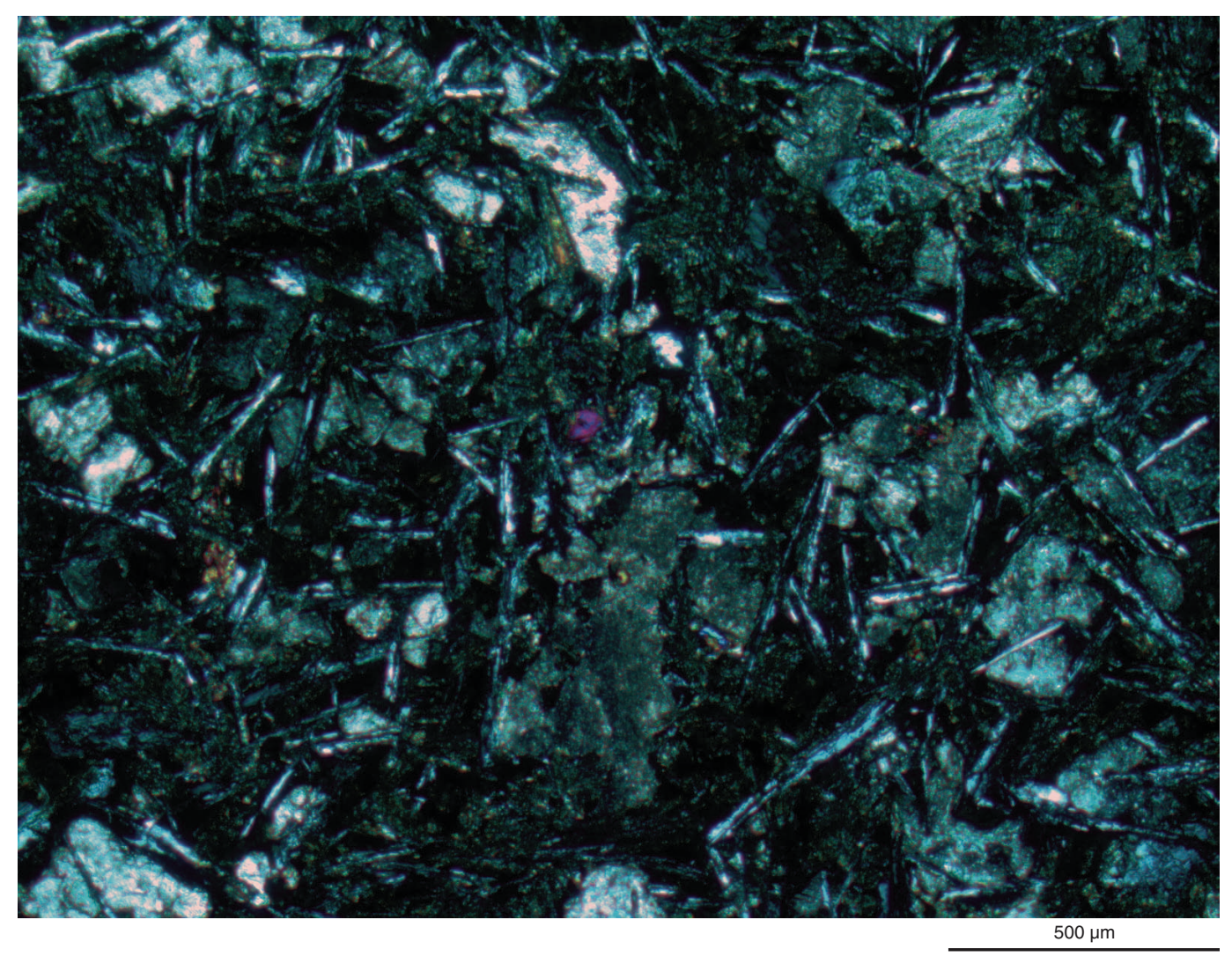


Figure F29. Photomicrograph of crosscutting calcite veins with boundary between gray and green alteration visible. The near-diagonal calcite vein has acted as a barrier for the alteration fluids responsible for brown alteration (Thin Section 51; Sample 324-U1346A-14R-2, 66-70 cm). Transmitted light.

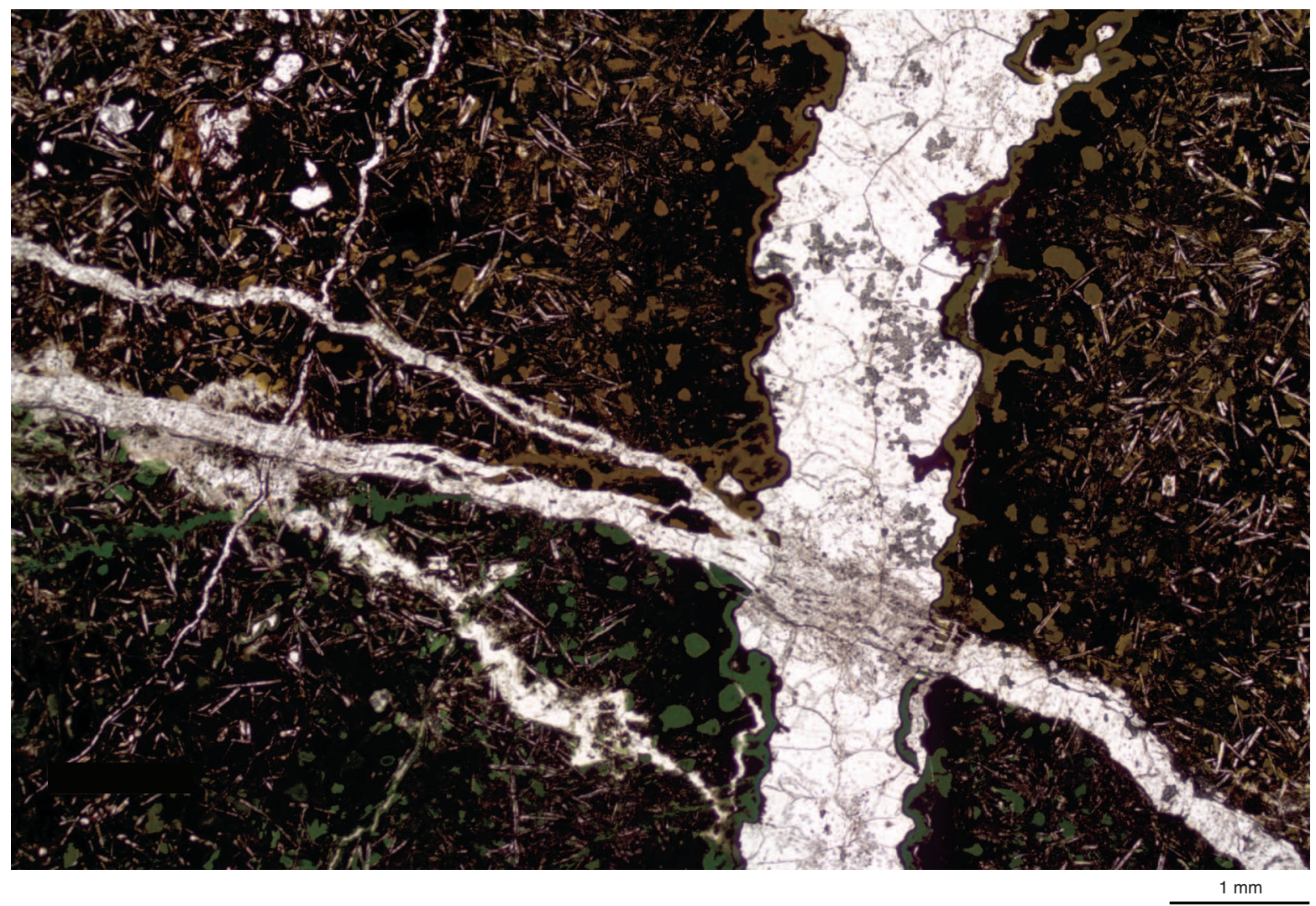


Figure F30. Photomicrograph of a vesicle filled with calcite and rimmed by dark clays in dark gray vesicular basalt (Sample 324-U1346A-7R-1, 52-54 cm). Cross-polarized light.

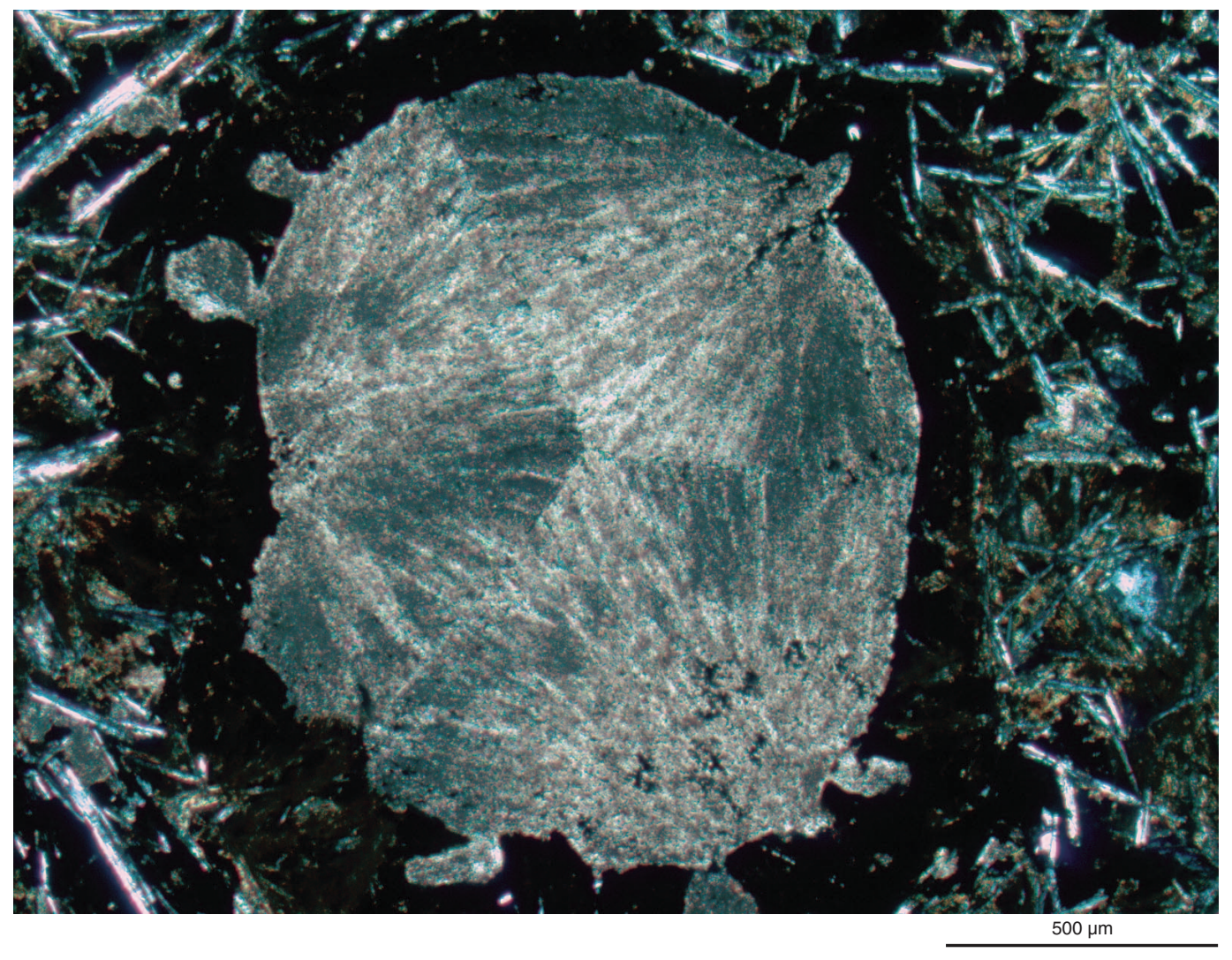


Figure F31. Photomicrograph of a vesicle filled with dark brown clay, green nontronite, and third-order birefringence fibrous saponite (Sample 324-U1346A-13R-1, 102-105 cm). Cross-polarized light.

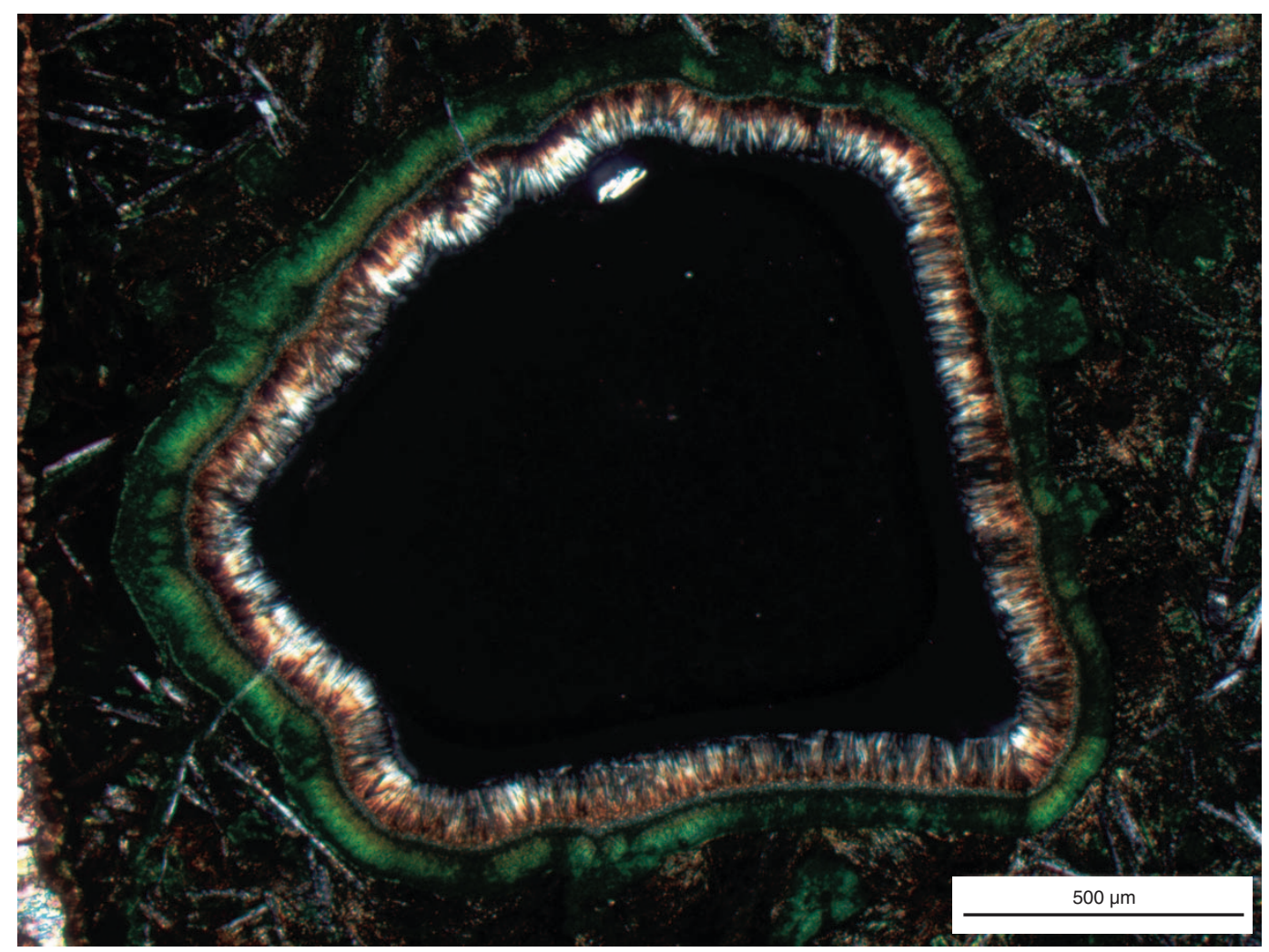


Figure F32. Downhole vein distribution, vein thickness, and occurrences of pyrite, Hole U1346A.

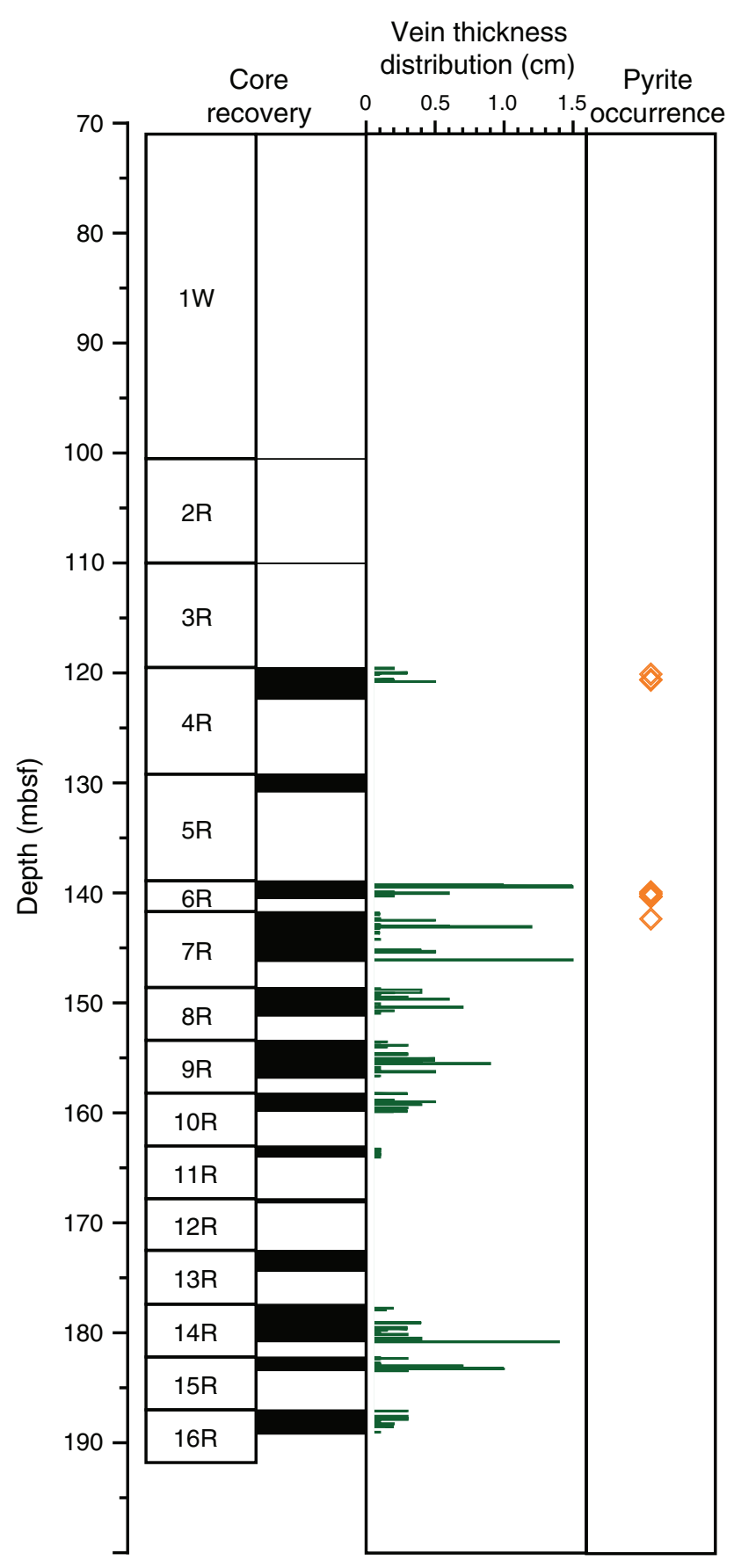


Figure F33. Close-up image of a calcite, nontronite, and pyrite vein (Sample 324-U1346A-6R-1, 115-120 cm).

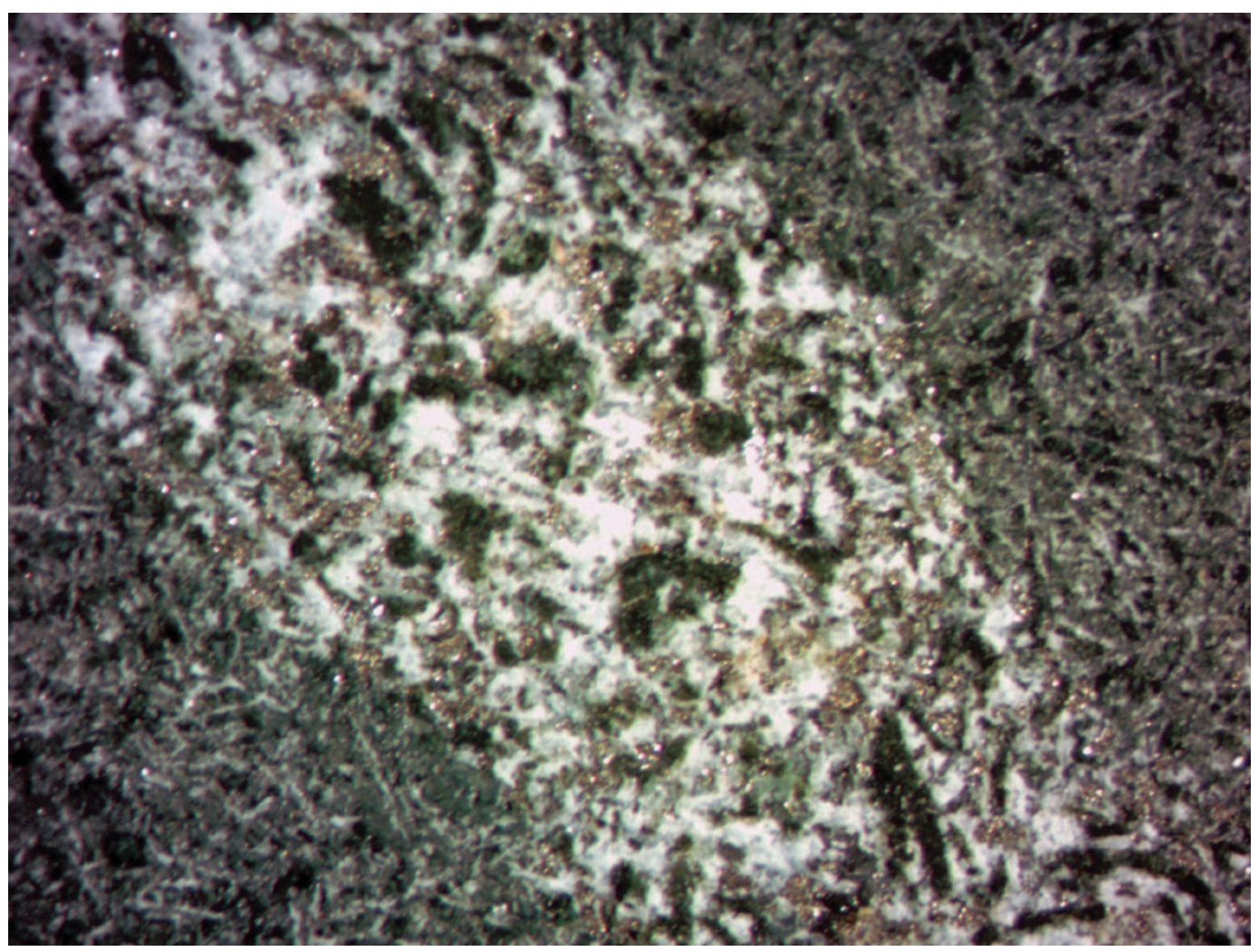


Figure F34. Close-up image of a calcite, nontronite, and Fe oxyhydroxide vein (Sample 324-U1346A-13R-1, 103-106 cm).

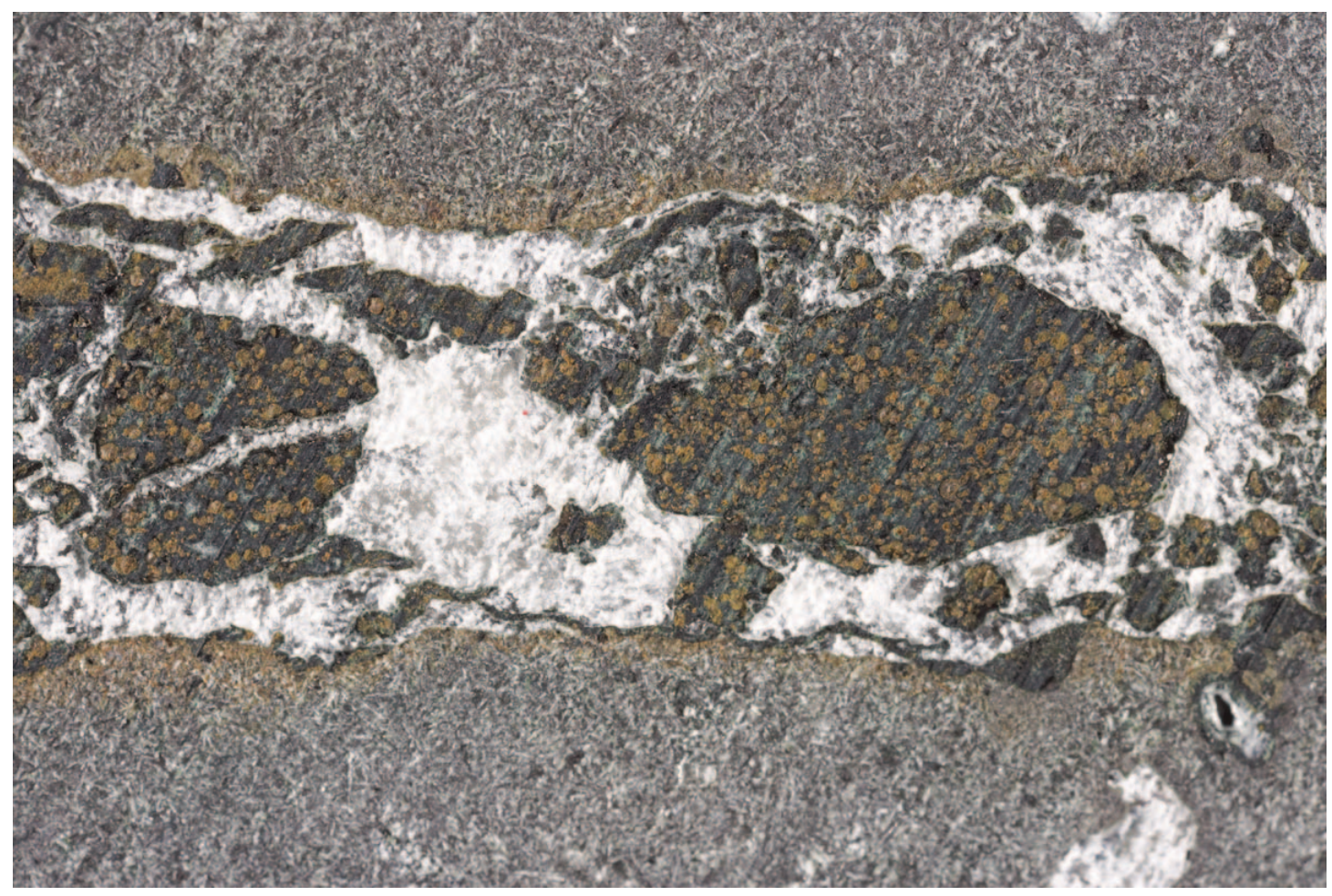


Figure F35. Core images of typical chilled margins, Hole U1346A. A. Interval 324-U1346A-8R-1, 40-73 cm. B. Interval 324-U1346A-13R-1, 119-143 cm.

A

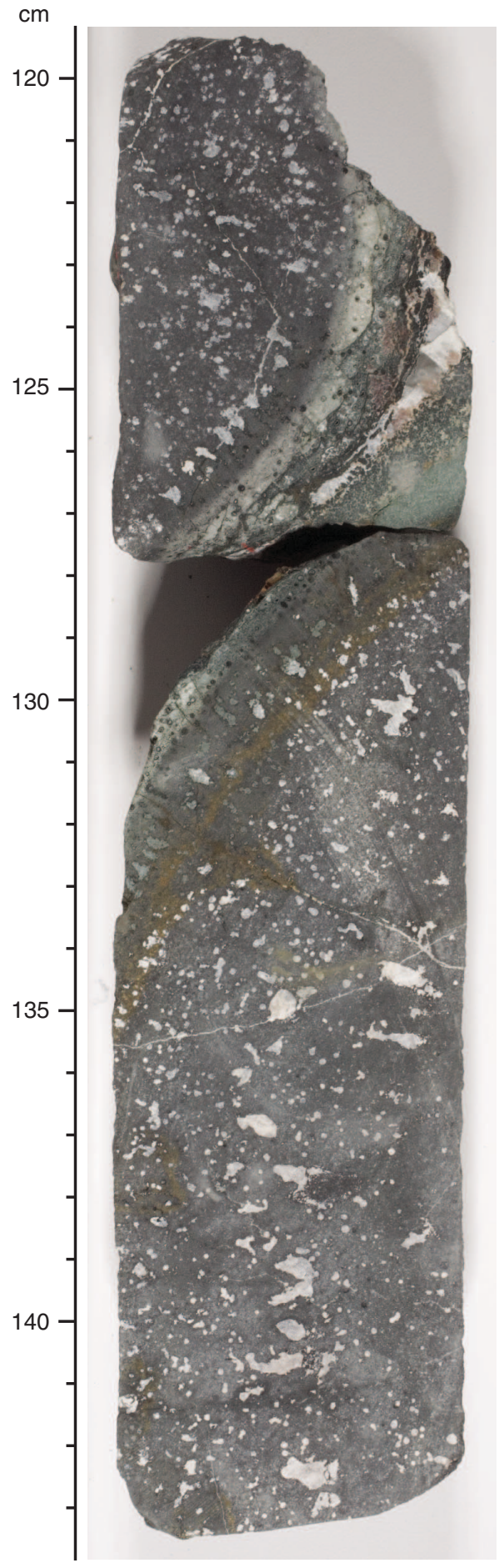

B

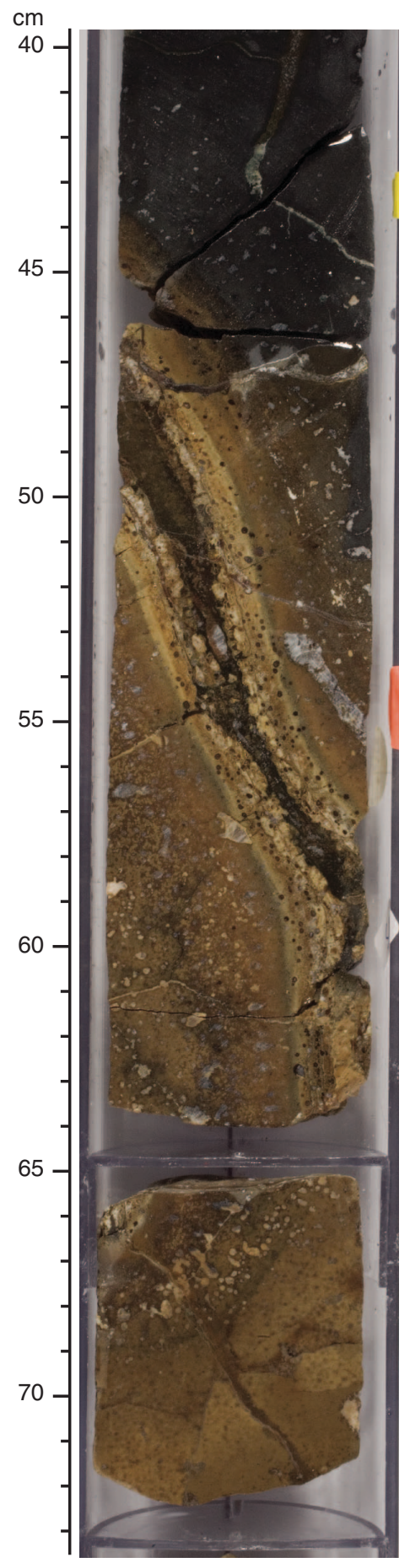


Figure F36. Core images of vein halos. A. Interval 324-U1346A-14R-2, 64-82 cm. B. Interval 324-U1346A-14R$3,21-40 \mathrm{~cm}$.

A

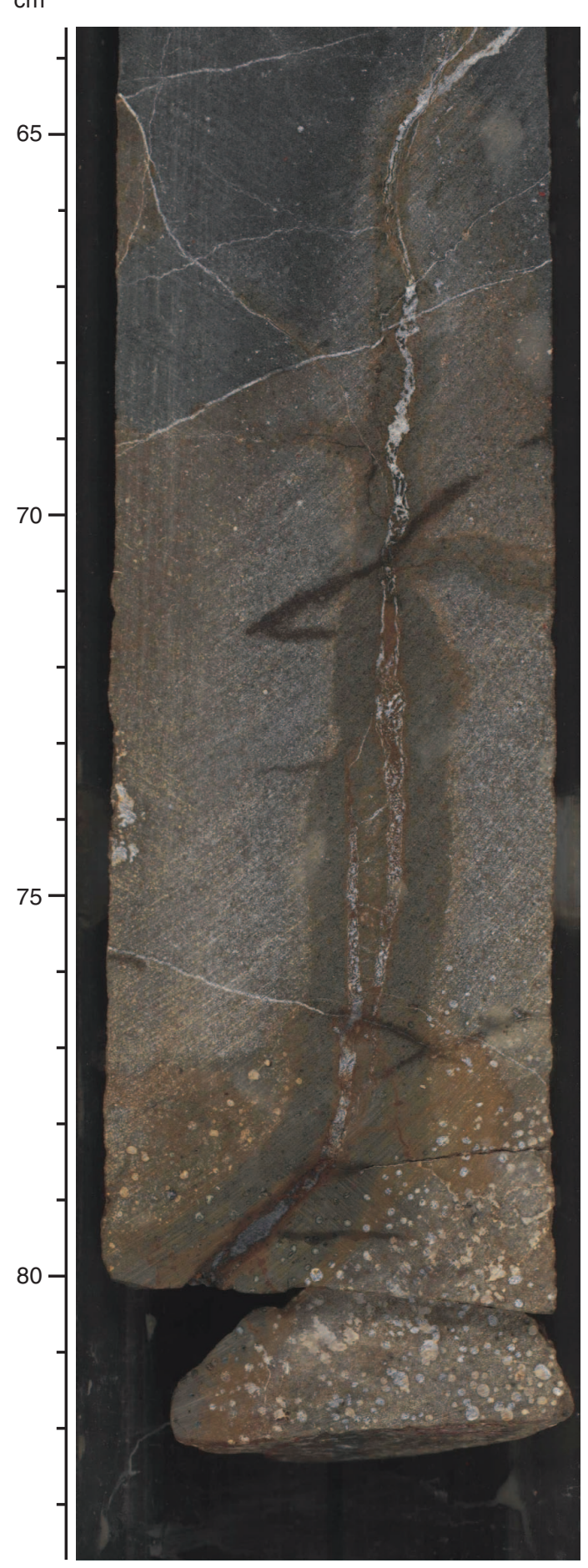

B

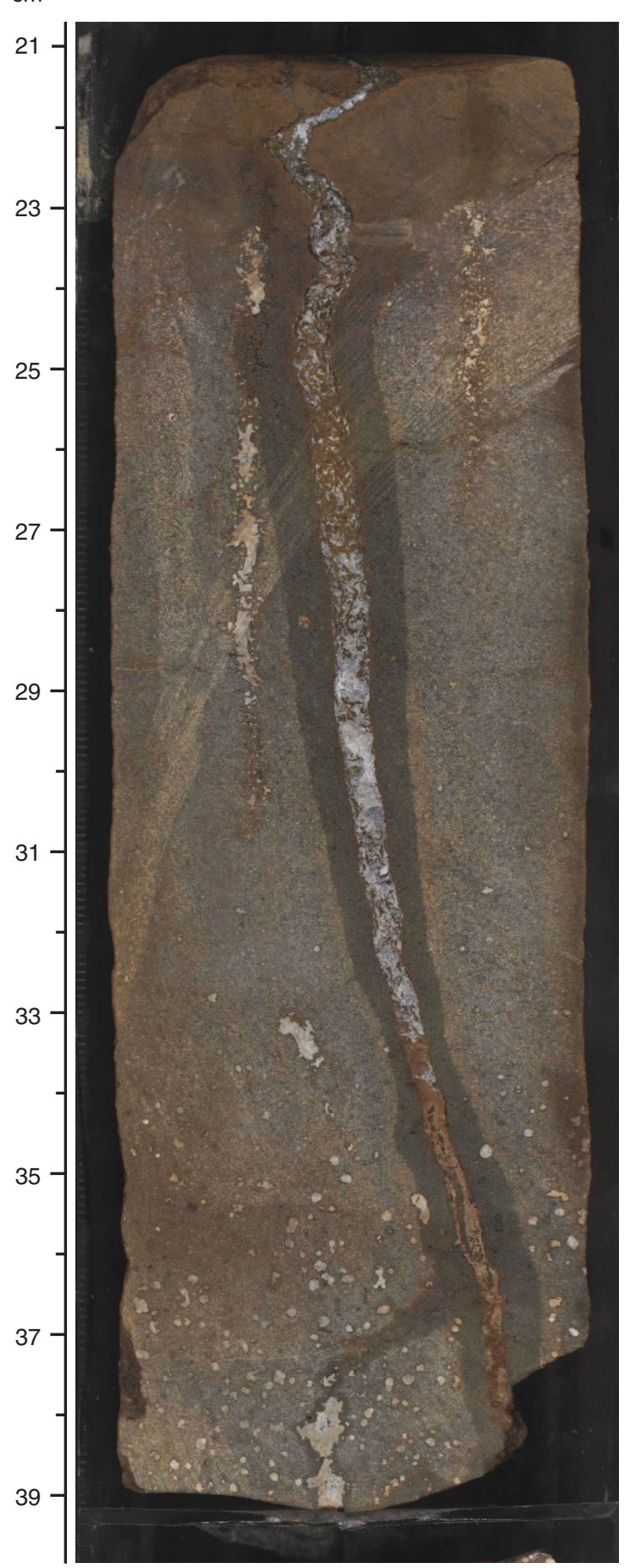


Figure F37. Photomicrographs of vein phenomena in Hole U1346A basalts. A. Conjugate veins (Thin Section 38; Sample 324-U1346A-11R-1, 34-35 cm). B. T-shaped vein filled with nontronite and polycrystalline calcites (Thin Section 59; Sample 324-U1346A-16R-2, 30-31 cm). C. Vesicle cut by veins and filled with nontronite, Fe hydroxide, and cross-fibrous calcites (Thin Section 47; Sample 324-U1346A-13R-1, 102-105 cm). D. En echelon veins (Thin Section 50; Sample 324-U1346A-14R-2, 36-37 cm). A and D are at 2.5× magnification, C and $\mathrm{B}$ are at $5 \times$ magnification. Plane-polarized light.
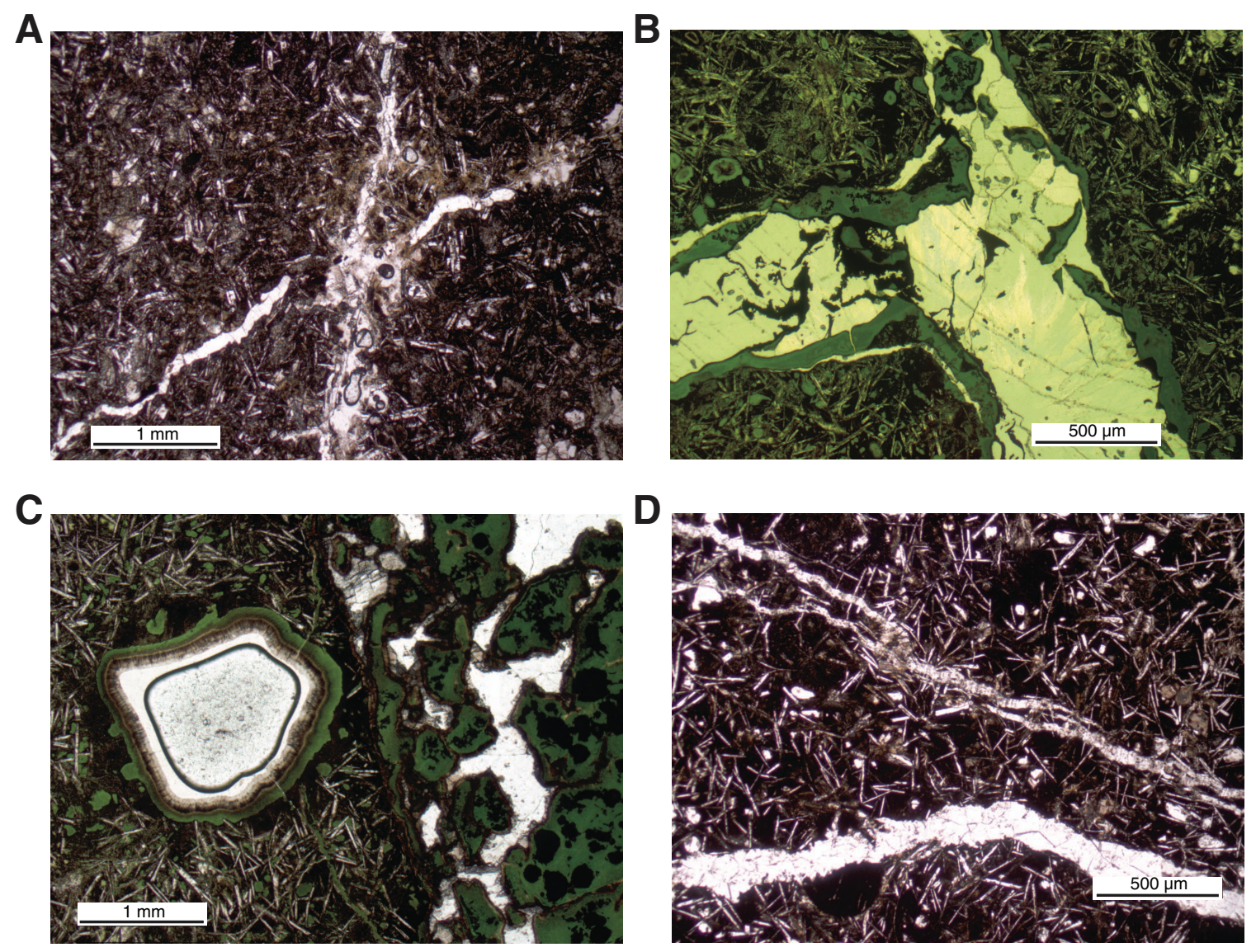
Figure F38. Close-up image of en echelon brown slivers, interpreted to record vein opening direction (red arrows) (interval 324-U1346A-14R-1, 33-35 cm).

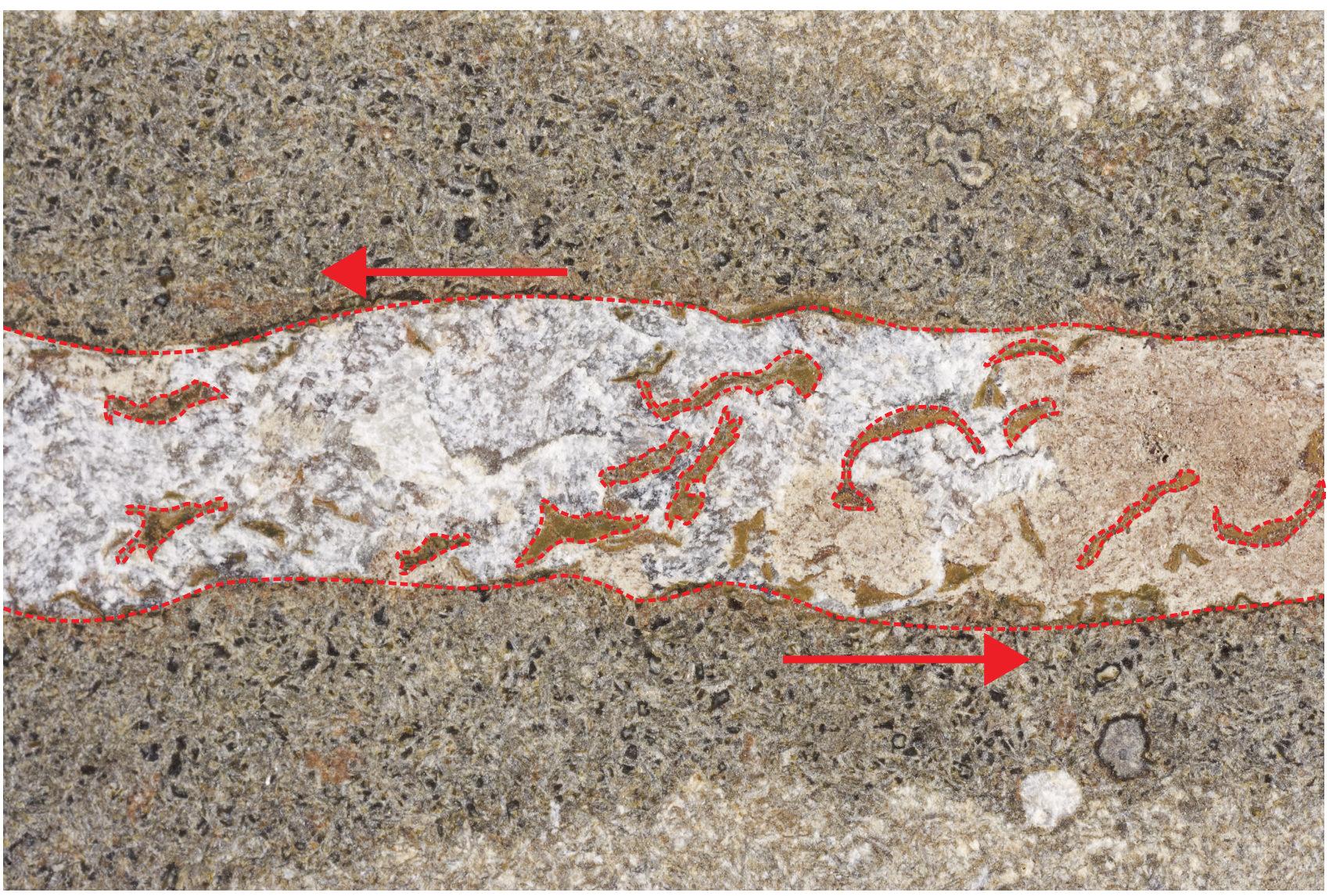


Figure F39. Sketch of structure in Section 324-U1346A-8R-1 showing a pile of stacked pillows, the sizes of which differ from 40 to $\sim 80 \mathrm{~cm}$. The pillow structure is characterized by radial cooling joints, radially aligned amygdules, and glassy inner rim.

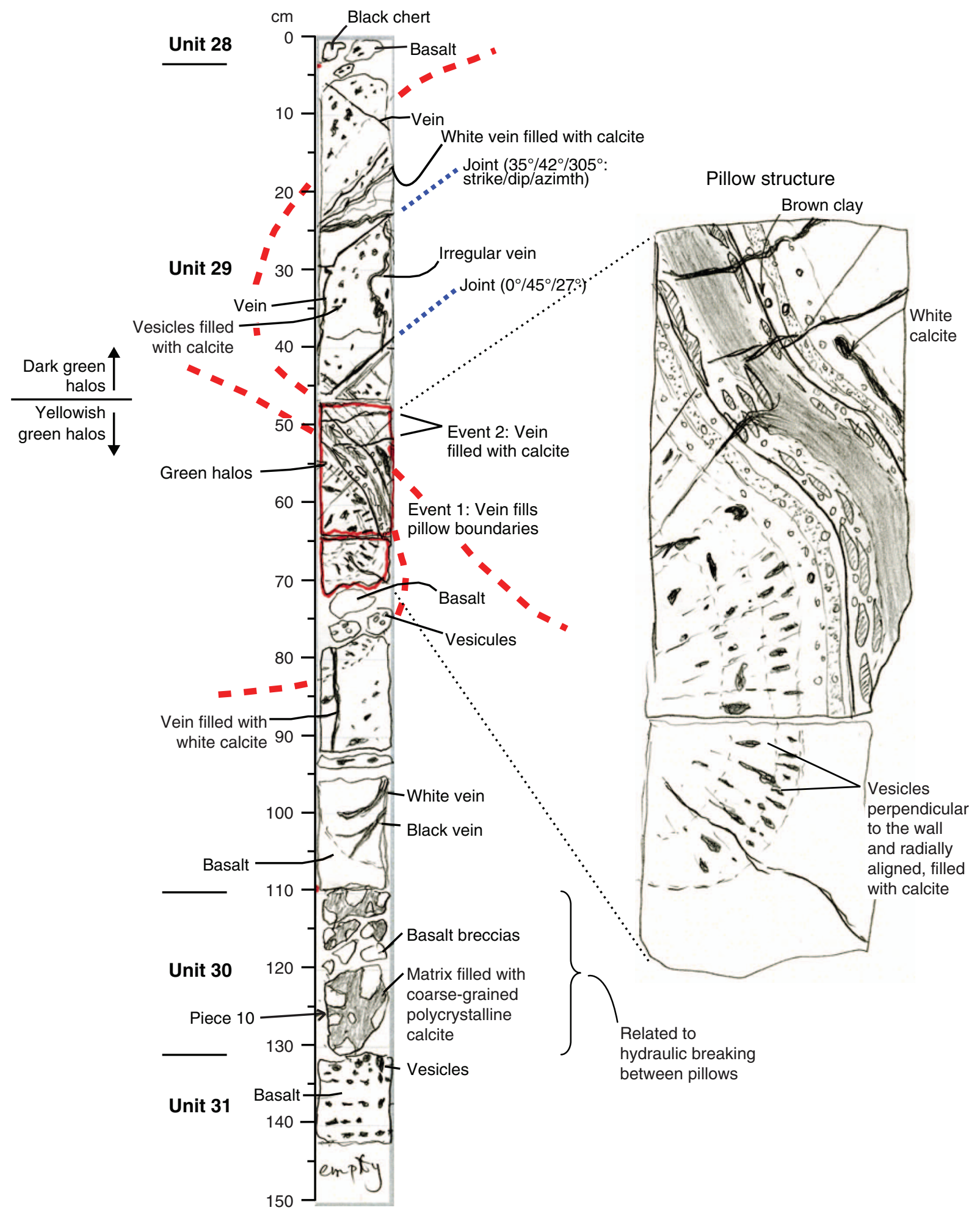


Figure F40. Sketch of structure in Section 324-U1346A-8R-2 showing a pile of stacked pillows from 20 to 40 $\mathrm{cm}$ in size.

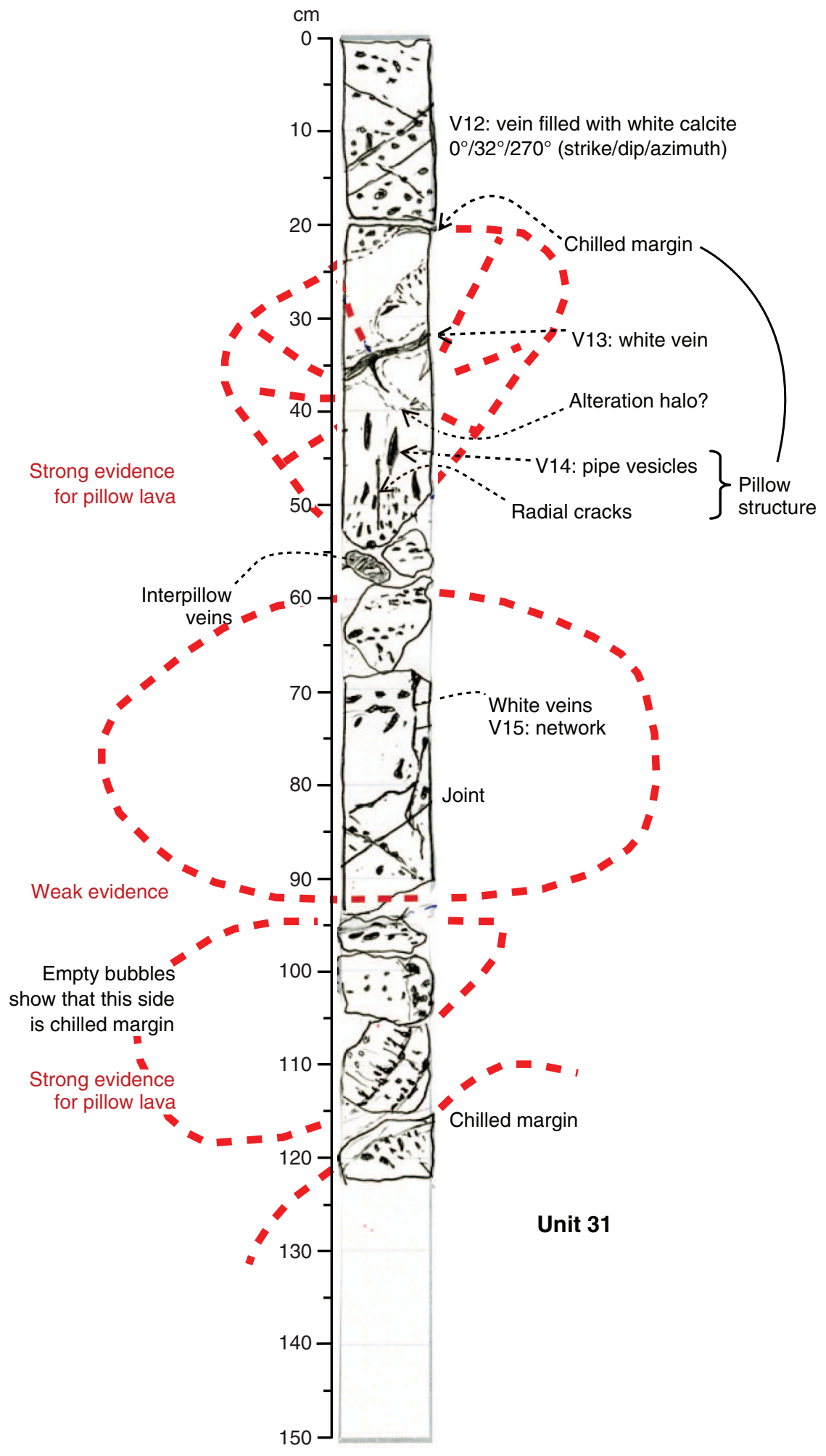


Figure F41. Sketch of structure in Section 324-U1346A-14R-1 showing a pile of stacked pillows $20 \mathrm{~cm}$ in size.

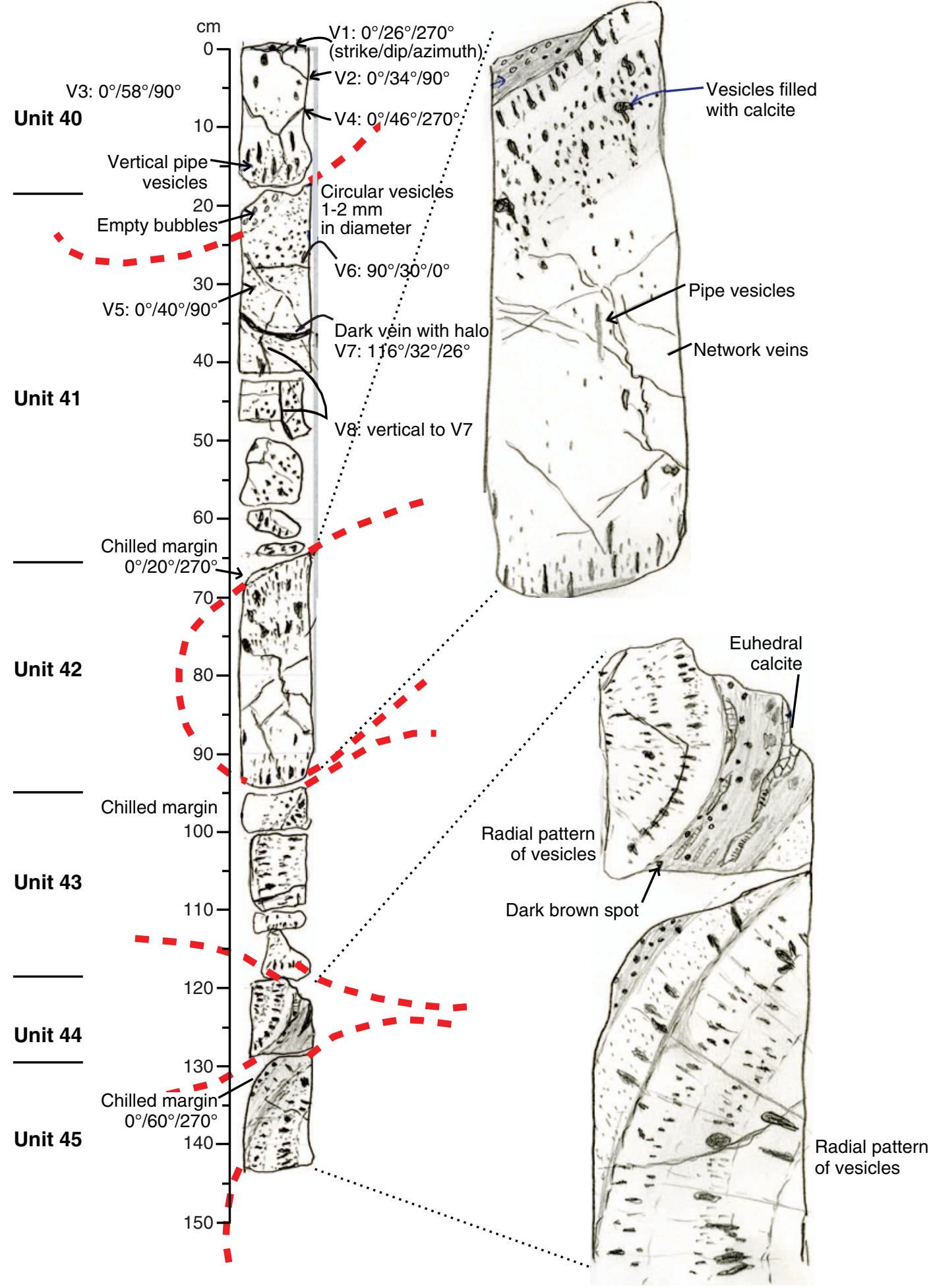


Figure F42. Sketch of structure in Section 324-U1346A-16R-2 showing a pile of stacked pillows from 40 to $\sim 60$ $\mathrm{cm}$ in size.

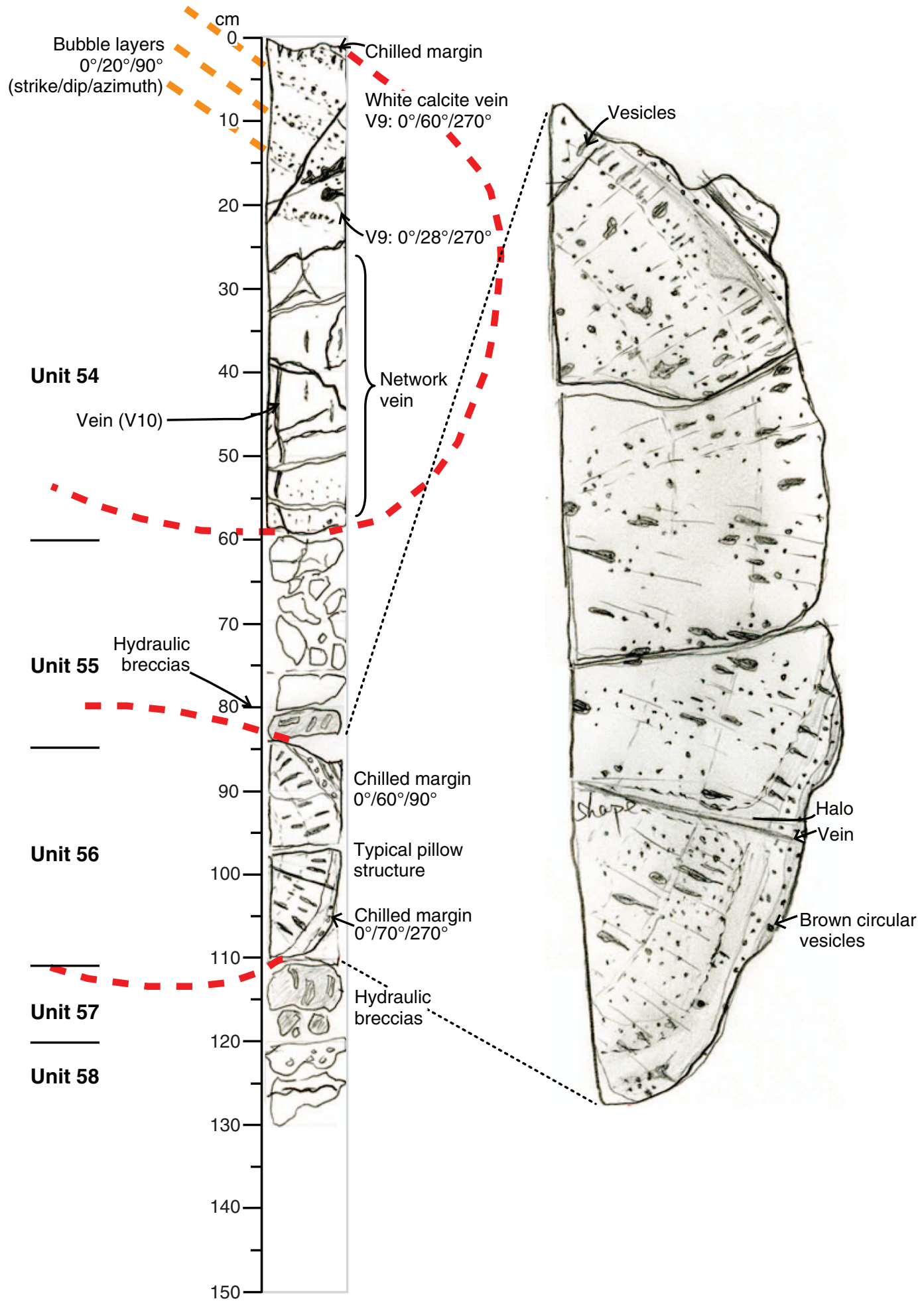


Figure F43. Rose diagrams of dips of structural features, Hole U1346A. All data are recorded in the LIMS database (iodp.tamu.edu/database/index.html). (Continued on next two pages.)

Veins
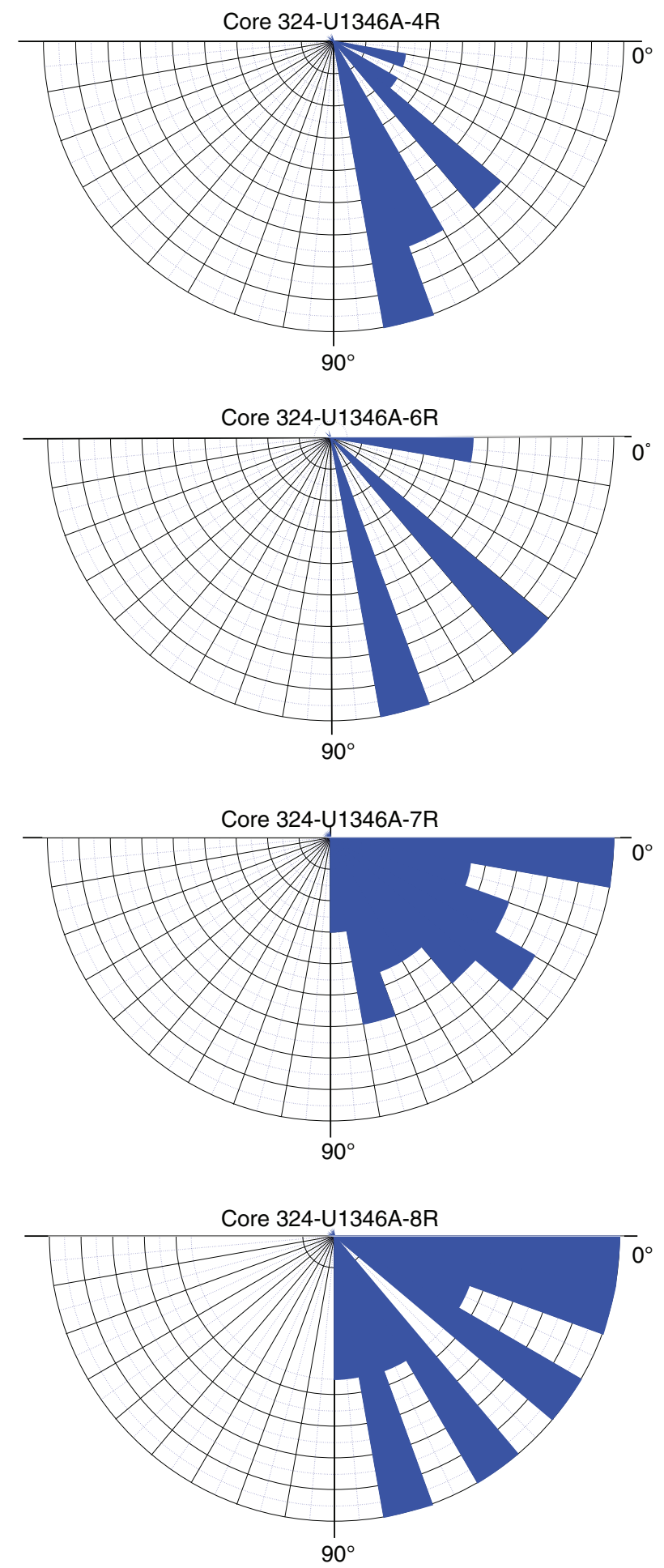

Joints
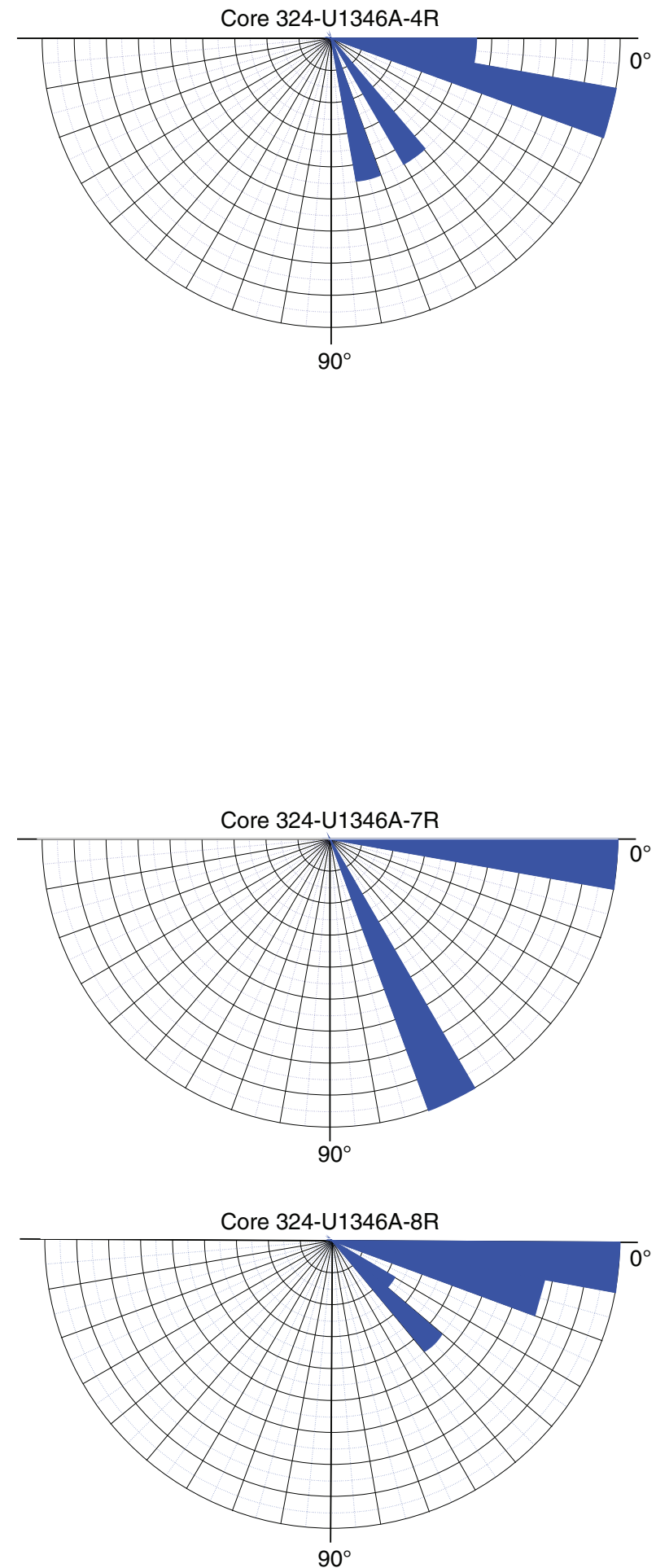
Figure F43 (continued). (Continued on next page.)

Veins
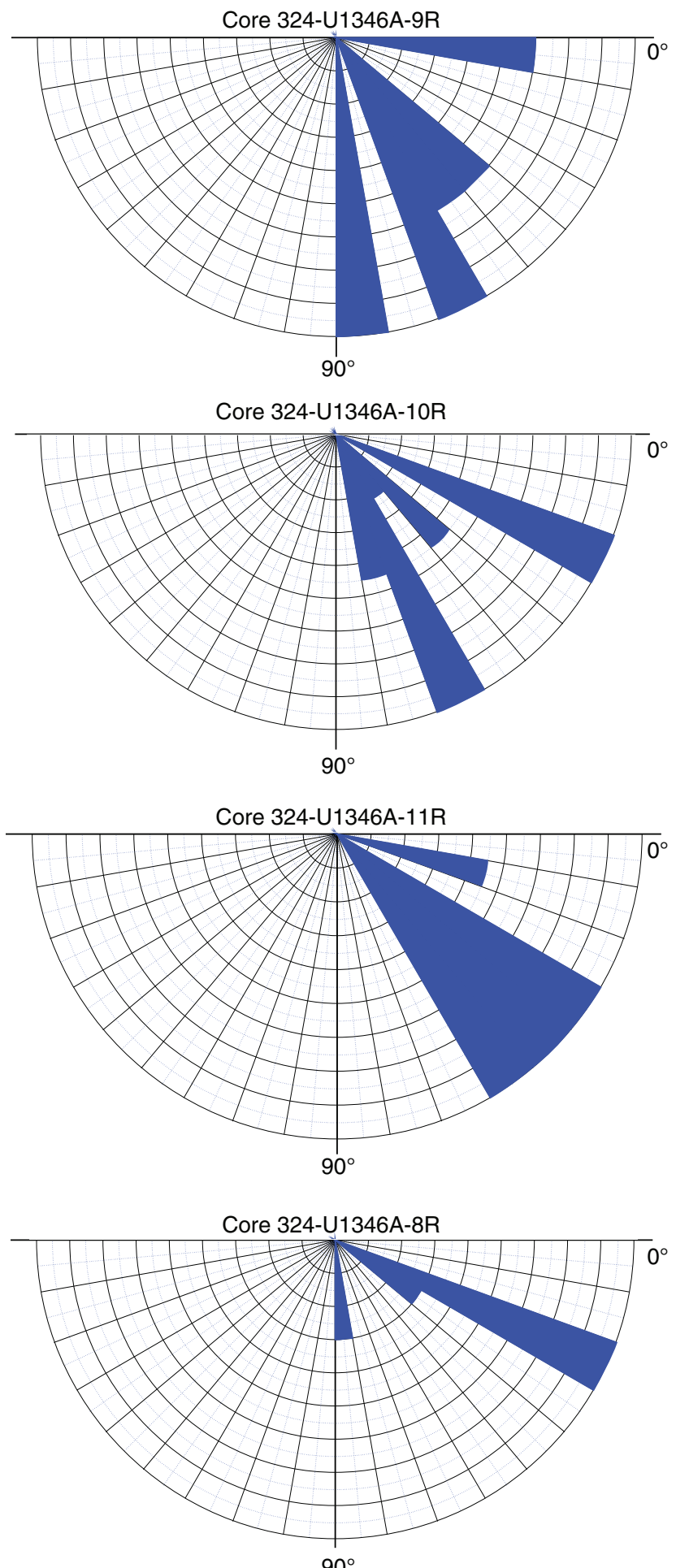

Joints

Core 324-U1346A-9R

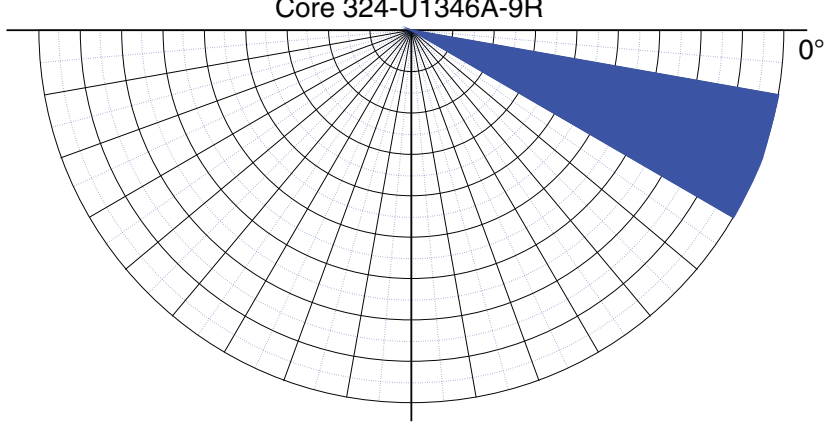

Core 324-U1346A-10R

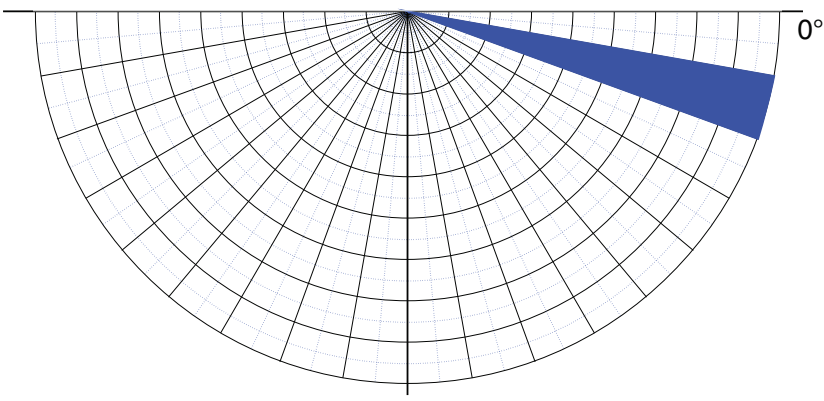

$90^{\circ}$

$90^{\circ}$ 
Figure F43 (continued).

Veins

Core 324-U1346A-13R
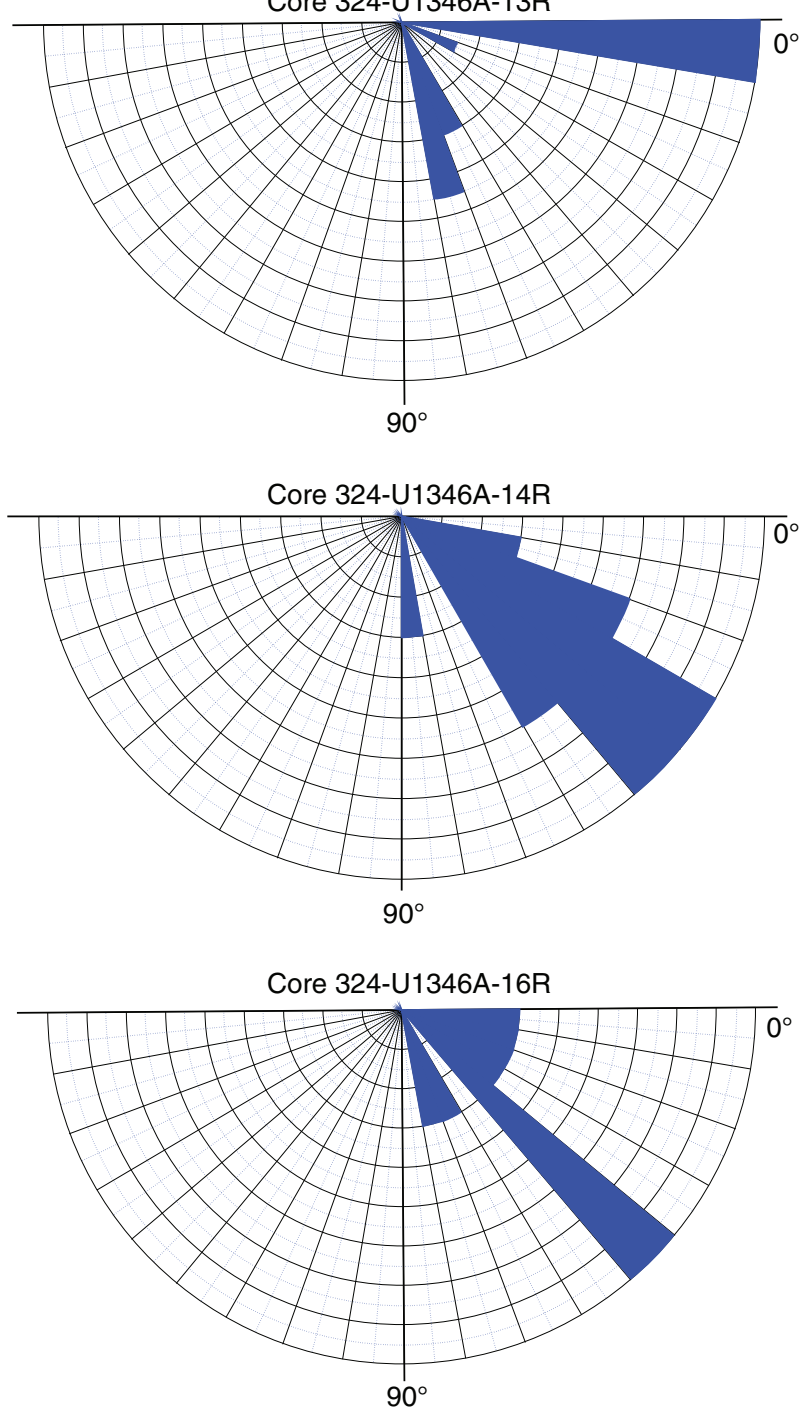

Site U1346

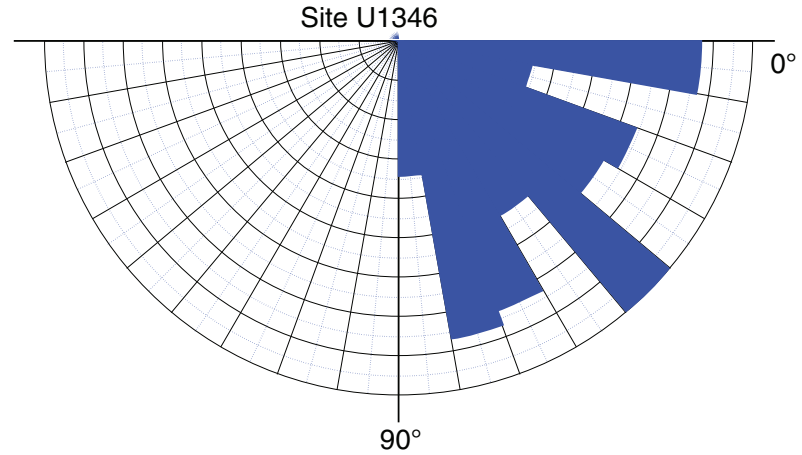

Joints

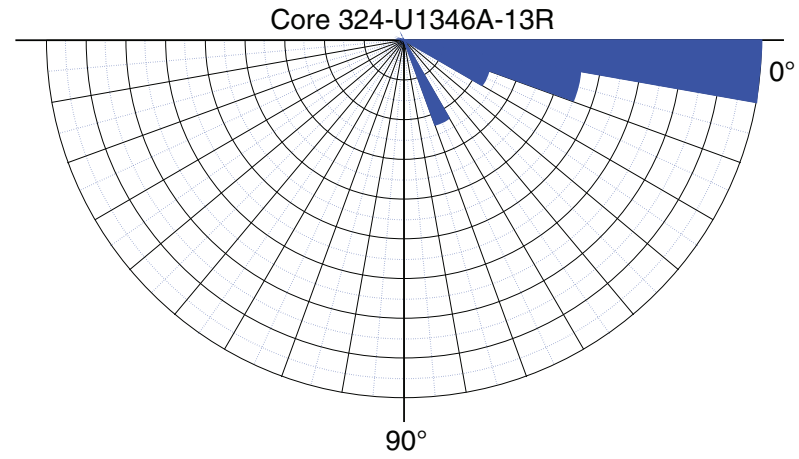

\section{.}




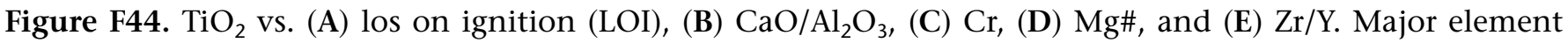
values normalized to $100 \mathrm{wt} \%$ totals. $\mathrm{Mg} \#=100 \times\left[\mathrm{Mg}^{2+} /\left(\mathrm{Mg}^{2+}+\mathrm{Fe}^{2+}\right)\right]$, assuming that $\mathrm{Fe}_{2} \mathrm{O}_{3} / \mathrm{FeO}=0.15$. Data for ODP Leg 191 Site 1179 and Leg 198 Site 1213 from Mahoney et al. (2005). OJP = Ontong Java Plateau (data of Tejada et al., 1996, 2002; Fitton and Godard, 2004), EPR = East Pacific Rise (data of Sinton et al., 1991; Bach et al., 1994; Mahoney et al., 1994), Nazca-ESC = Nazca Ridge and Easter seamount chain (Ray et al., unpubl. data). The Nazca Ridge and Easter seamount chain together form the hotspot trail of the Easter-Salas hotspot.
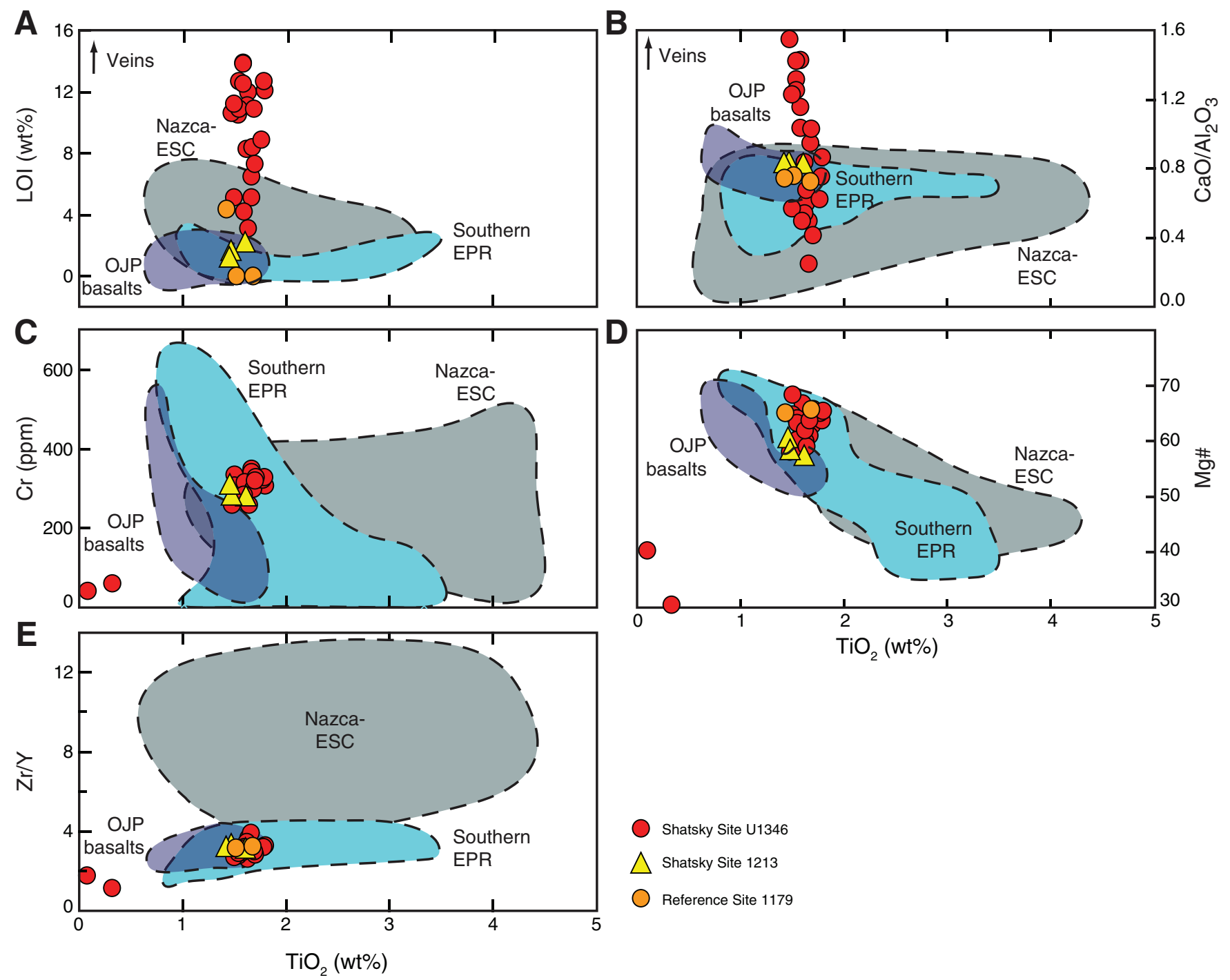

Shatsky Site U1346

Shatsky Site 1213

Reference Site 1179 
Figure F45. Total alkalis vs. silica with Le Maitre et al.'s (1989) classification of volcanic rock types. Values normalized to $100 \mathrm{wt} \%$ totals. Heavy dashed line = division of data for tholeiitic and alkalic lavas of Hawaii (Macdonald and Katsura, 1964; Macdonald, 1968). OJP = Ontong Java Plateau (data of Tejada et al., 1996, 2002; Fitton and Godard, 2004), EPR = East Pacific Rise (data of Sinton et al., 1991; Bach et al., 1994; Mahoney et al., 1994), Nazca-ESC = Nazca Ridge and Easter seamount chain (data of Ray et al., submitted).

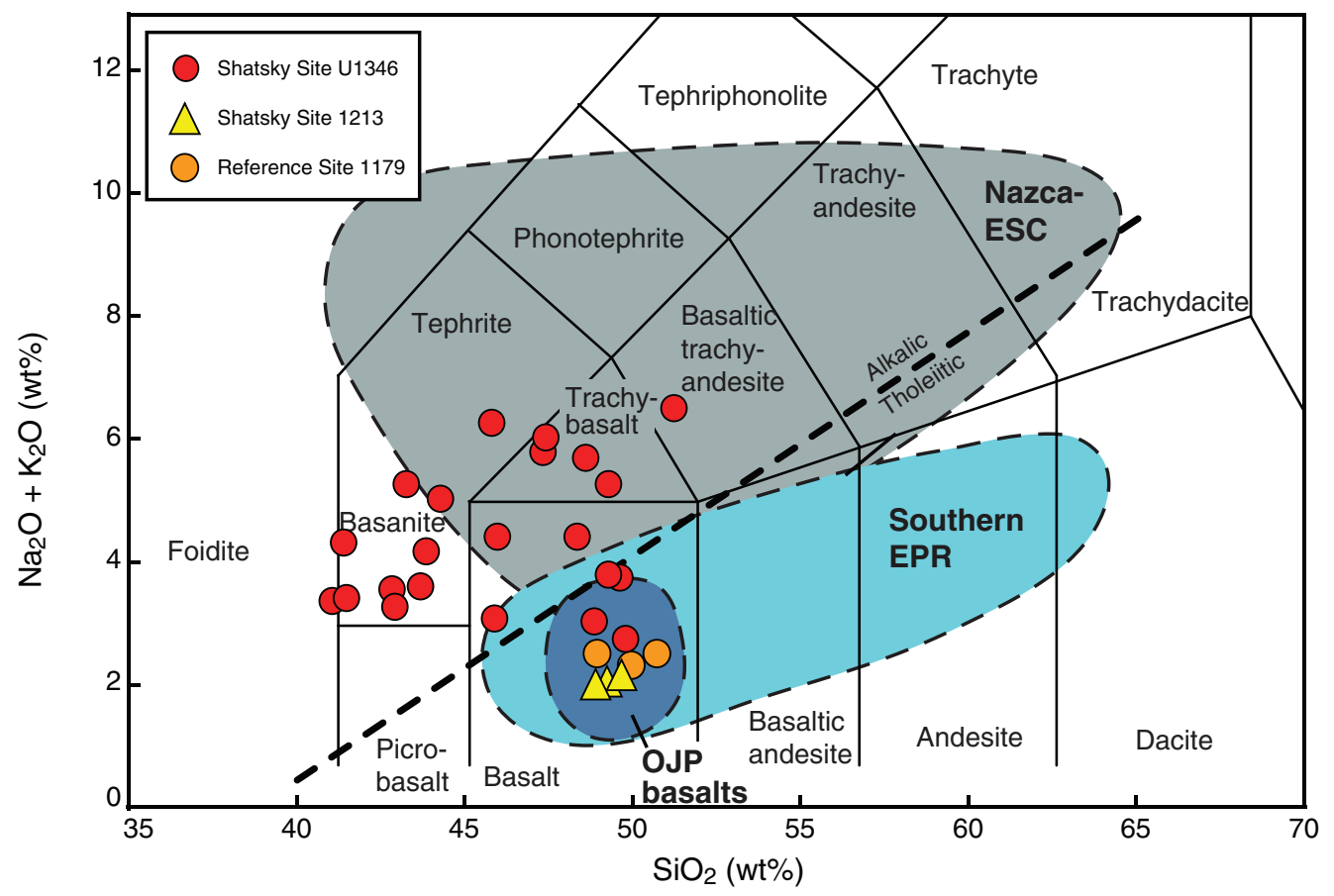


Figure F46. Physical property summary including both whole-round and discrete sample data, Site U1346. $\mathrm{NGR}=$ natural gamma radiation, GRA = gamma ray attenuation .

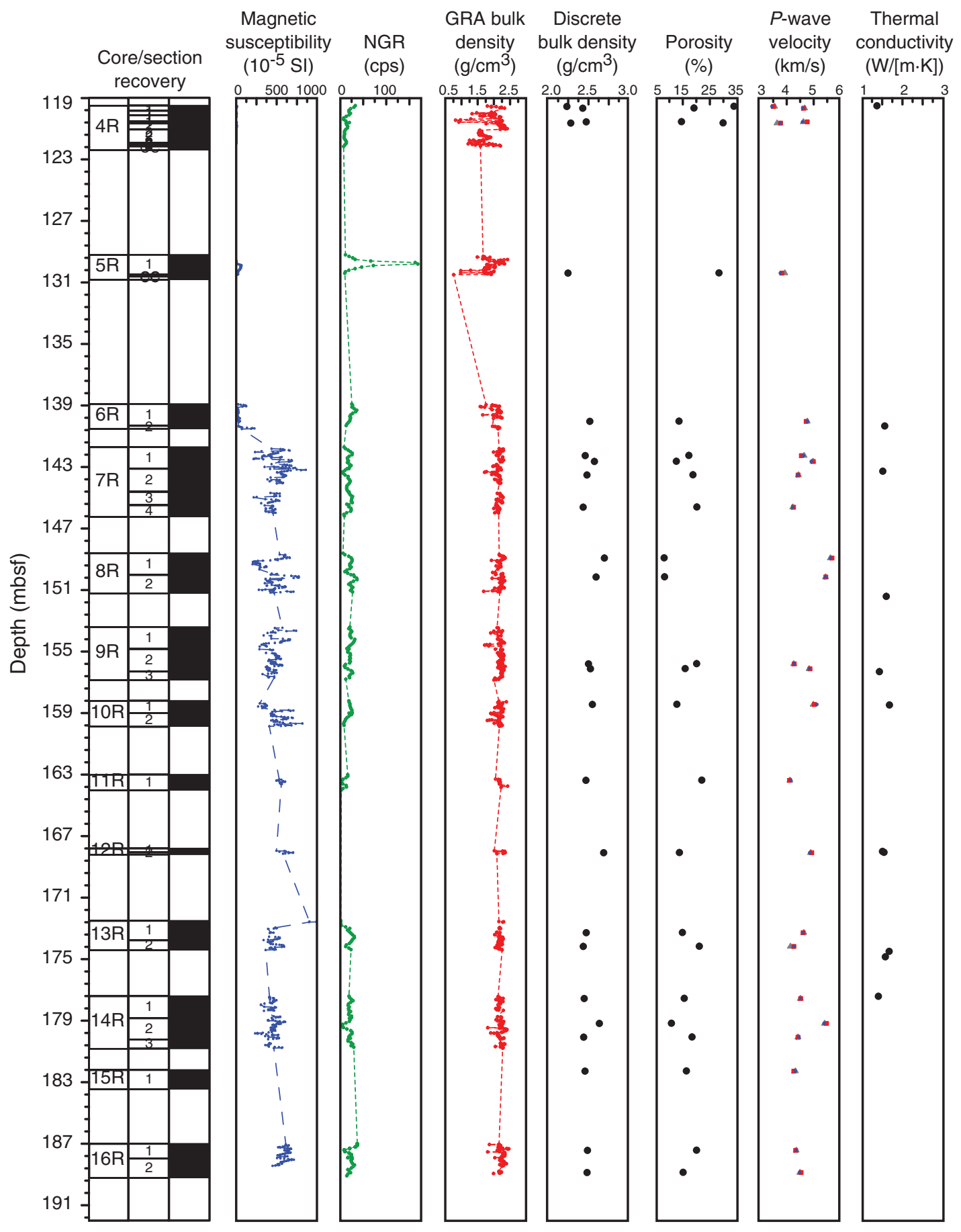


Figure F47. Physical property details from selected sections of Hole U1346A. A. Bulk GRA density through a sequence of sediments and basalts. Dark red triangles = discrete MAD measurements. B. Correlation of magnetic susceptibility and natural gamma ray (NGR) total counts per second from the Natural Gamma Ray Logger. C. Correlation of decreasing magnetic susceptibility at the change from gray to brown alteration (see "Alteration and metamorphic petrology"). Note the lack of change in bulk density through changing alteration styles. Light red circles = GRA density, dark red triangles = discrete measurements. D. Variation in magnetic susceptibility through a continuous section of core, perhaps related to changing mineralogical characteristics.
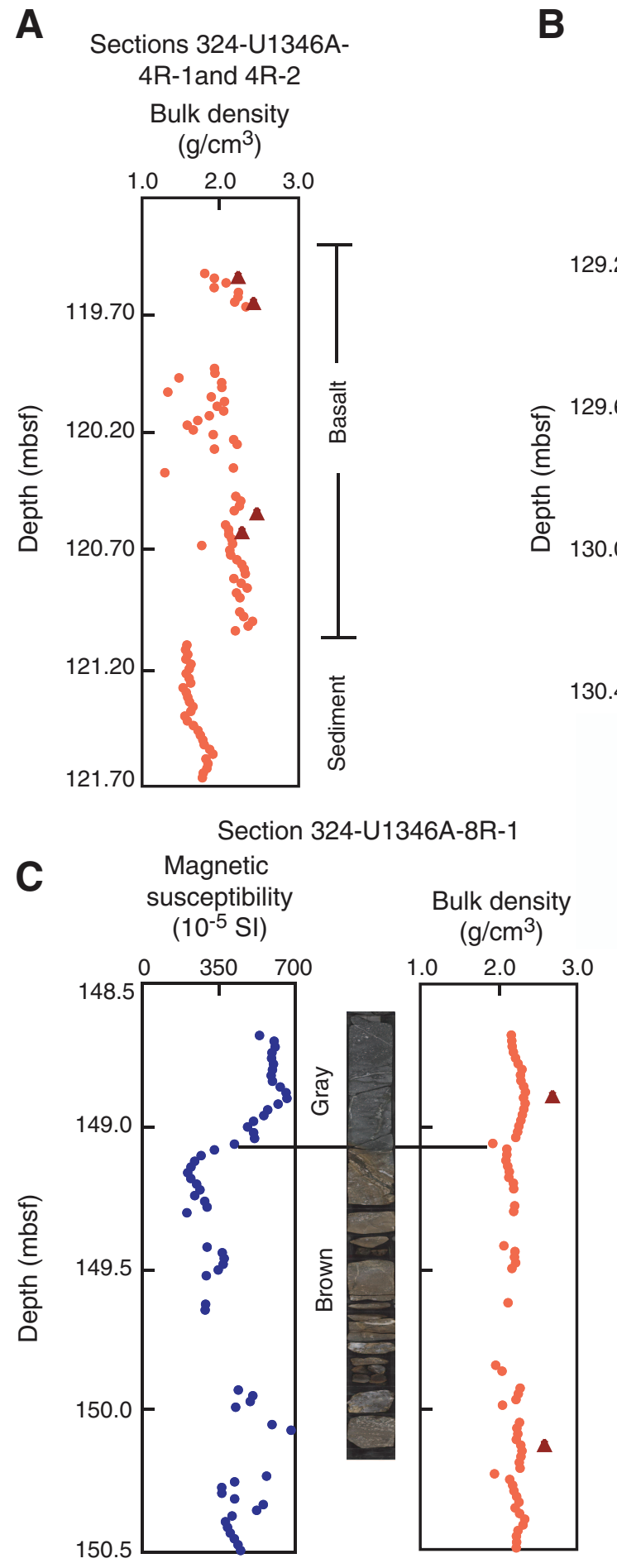
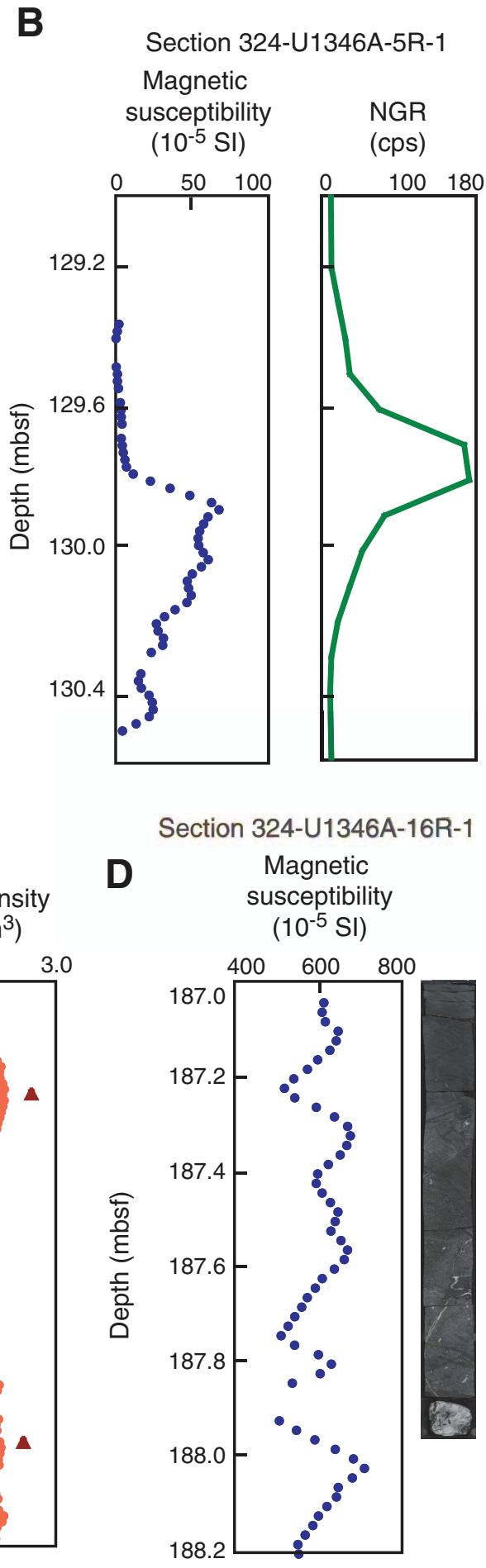
Figure F48. Example of gamma ray spectra generated by the Natural Gamma Ray Logger. Green spectrum is from the sedimentary sequence with high total counts ( 180 cps) in interval 324-U1346A-5R-1, $60 \mathrm{~cm}$. Blue spectrum is from basaltic interval 324-U1346A-8R-2, $60 \mathrm{~cm}$, plotted on the same relative scale for direct comparison. The spectra show that basaltic counts are dominated by potassium, whereas the major contributor to the sedimentary sequence are daughter nuclides of the ${ }^{238} \mathrm{U}$ decay chain, in particular ${ }^{214} \mathrm{Bi}$. The low energy spectra of the sedimentary section also consists mainly of ${ }^{238} \mathrm{U}$ decay products such as ${ }^{226} \mathrm{Ra},{ }^{214} \mathrm{~Pb}$, and ${ }^{214} \mathrm{Po}$ (individual peaks not labeled).

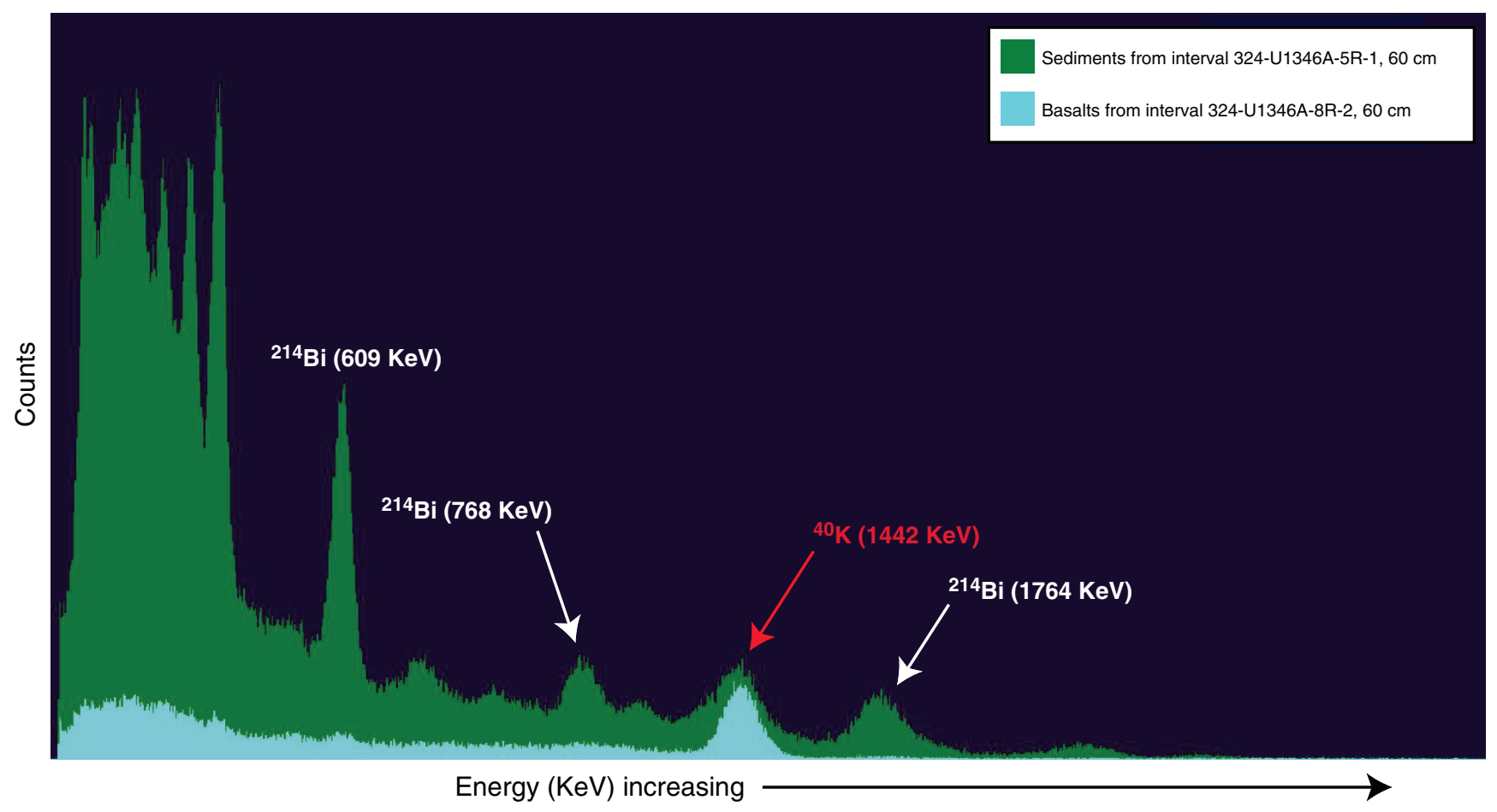


Figure F49. Calculated moisture and density characteristics vs. depth from measurement of discrete samples, Hole U1346A.

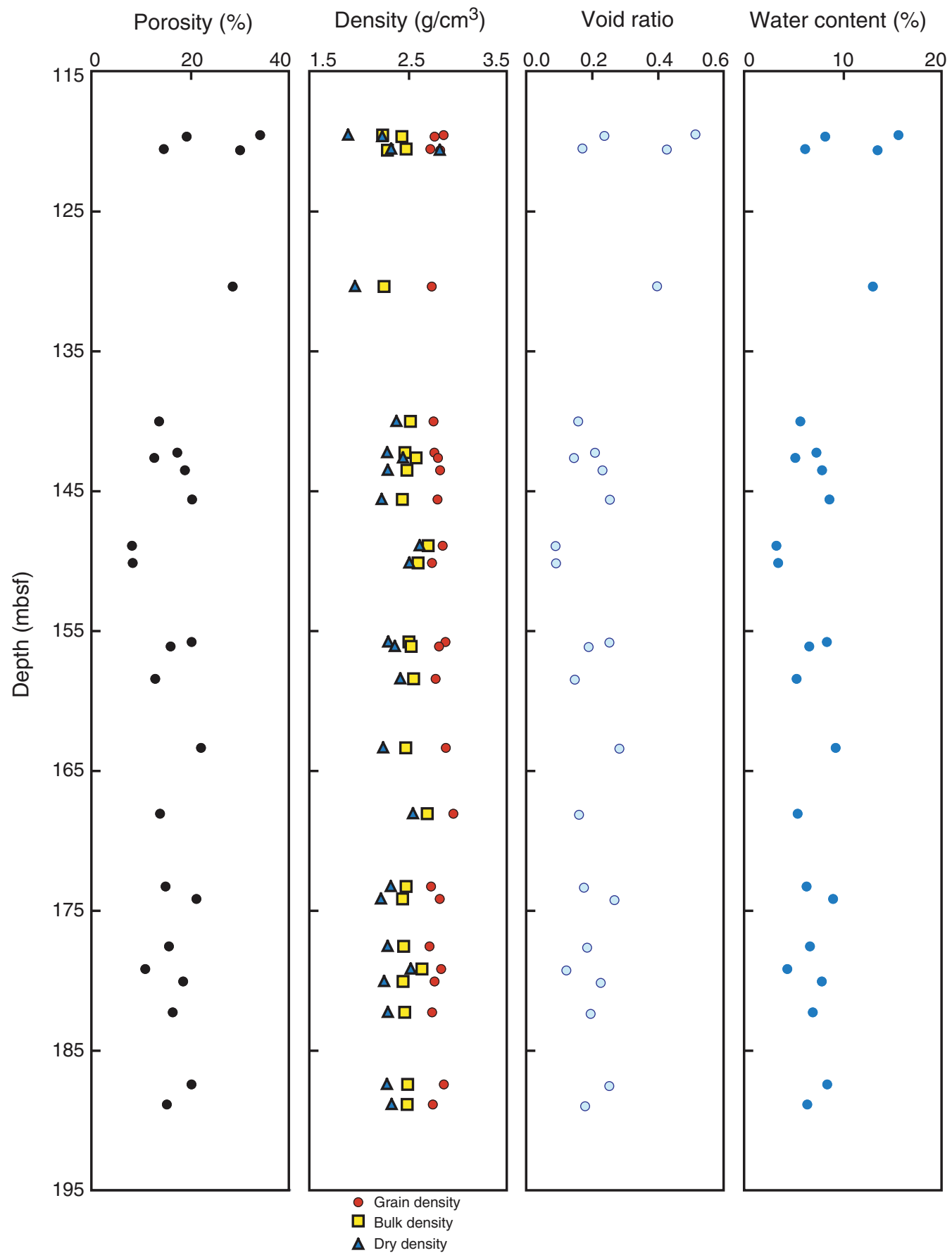


Figure F50. Correlation of $P$-wave measurements (in $z$-direction) with wet bulk density from MAD calculations, Hole U1346A.

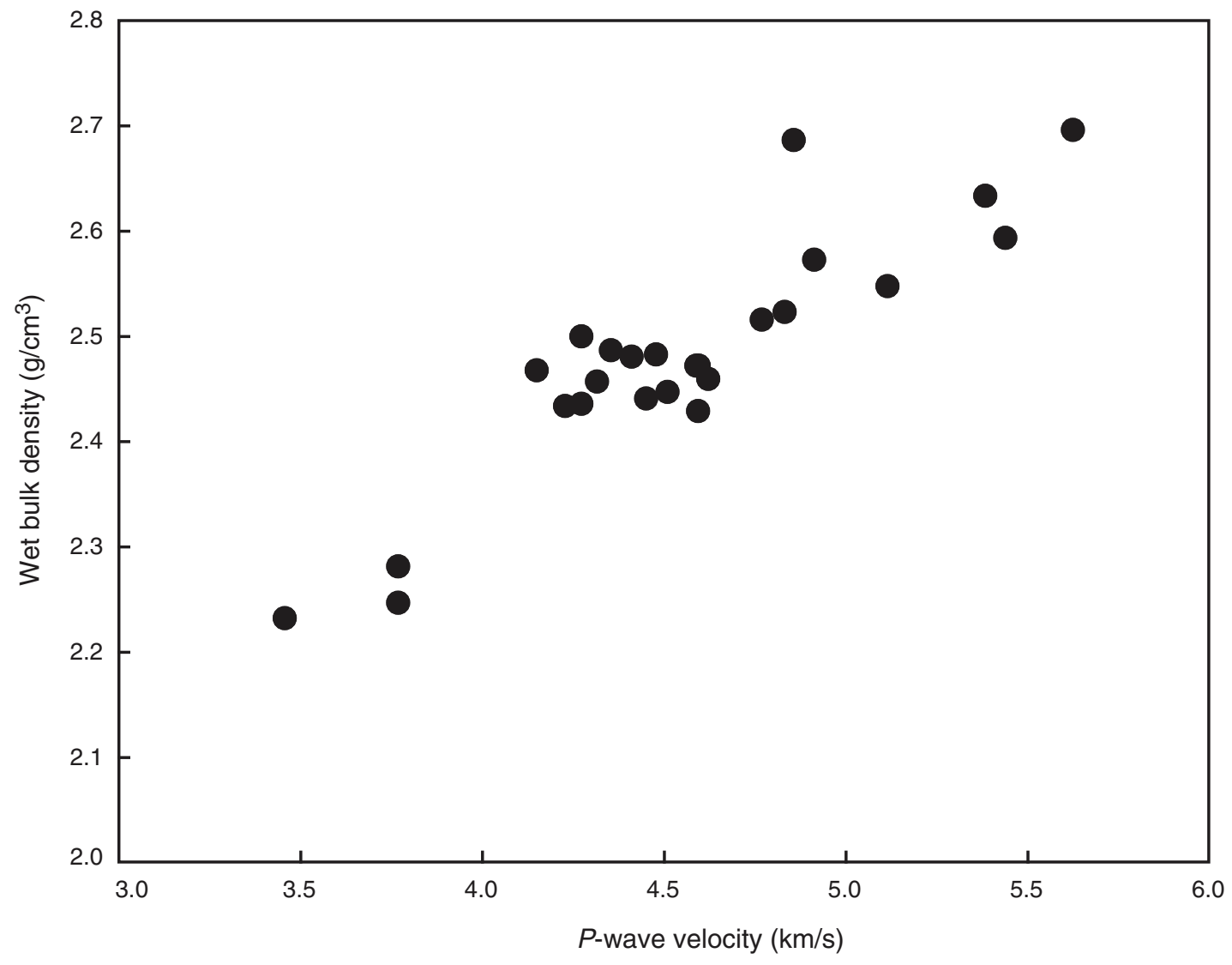


Figure F51. Example orthogonal vector plots of alternating-field and thermal demagnetization results, Hole U1346A. Open circles $=$ inclinations, solid circles $=$ declinations. $\mathrm{NRM}=$ natural remanent magnetization, gray circles and lines = demagnetization steps that were not used in the PCA calculation. (A) Zijderveld diagram and (B) intensity spectrum during alternating-field demagnetization of Sample 324-U1346A-7R-2, 39-41 cm. (C) Zijderveld diagram and (D) intensity spectrum and (E) magnetic susceptibility variation during thermal demagnetization of Sample 324-U1346A-6R-1, 111-113 cm.

A Sample 324-U1346A-7R-2, 39-41 cm

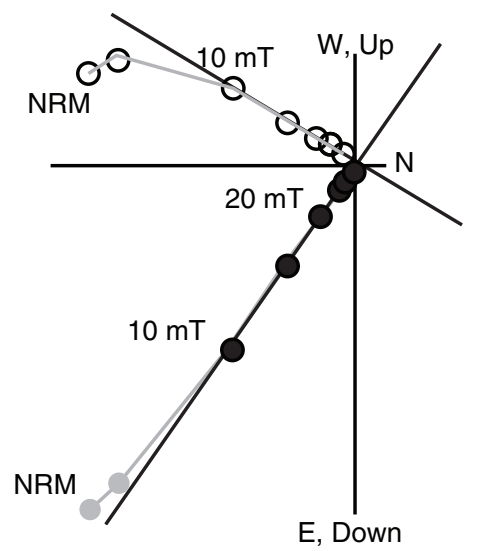

C Sample 324-U1346A-6R-1, 111-113 cm

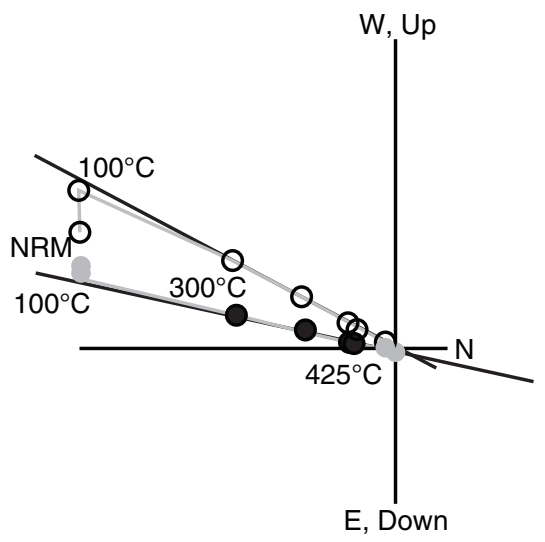

E Sample 324-U1346A-6R-1, 111-113 cm

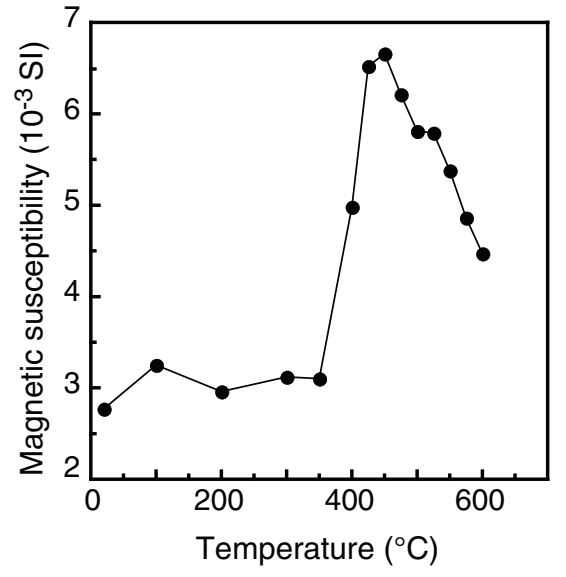

B Sample 324-U1346A-7R-2, 39-41 cm

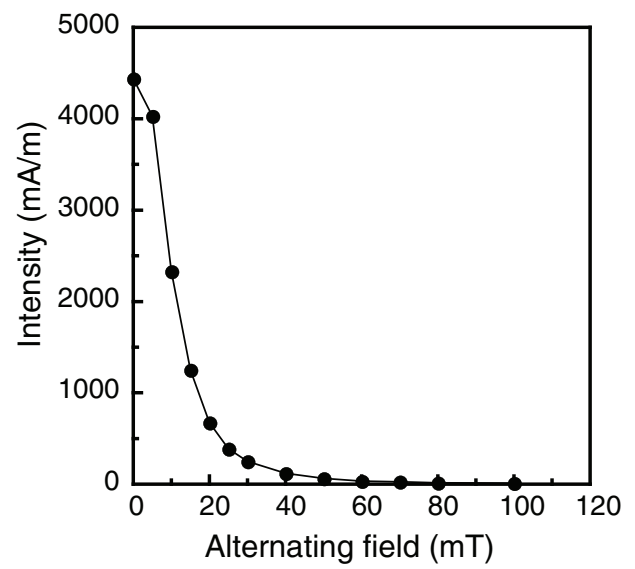

D Sample 324-U1346A-6R-1, 111-113 cm

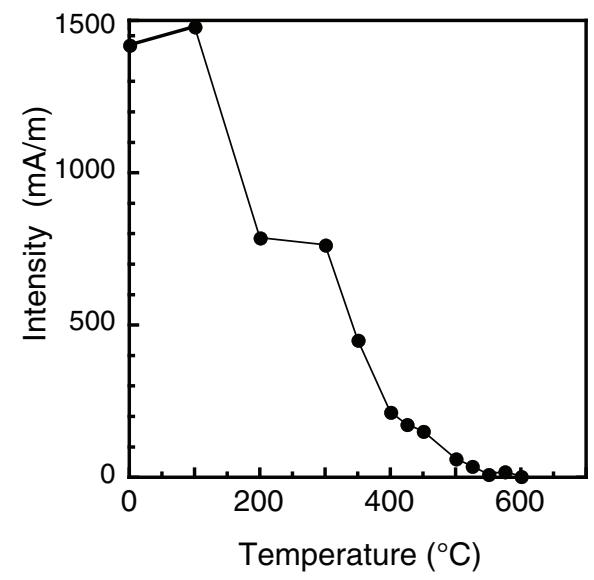


Figure F52. Downhole inclination plots from demagnetization results, Hole U1346A. Dotted line = average inclination value $\left(-20.3^{\circ}\right)$ calculated from all the accepted inclination data points. Gray zone $=$ calculated standard deviation from all the inclination data points $\left( \pm 5.4^{\circ}\right)$.

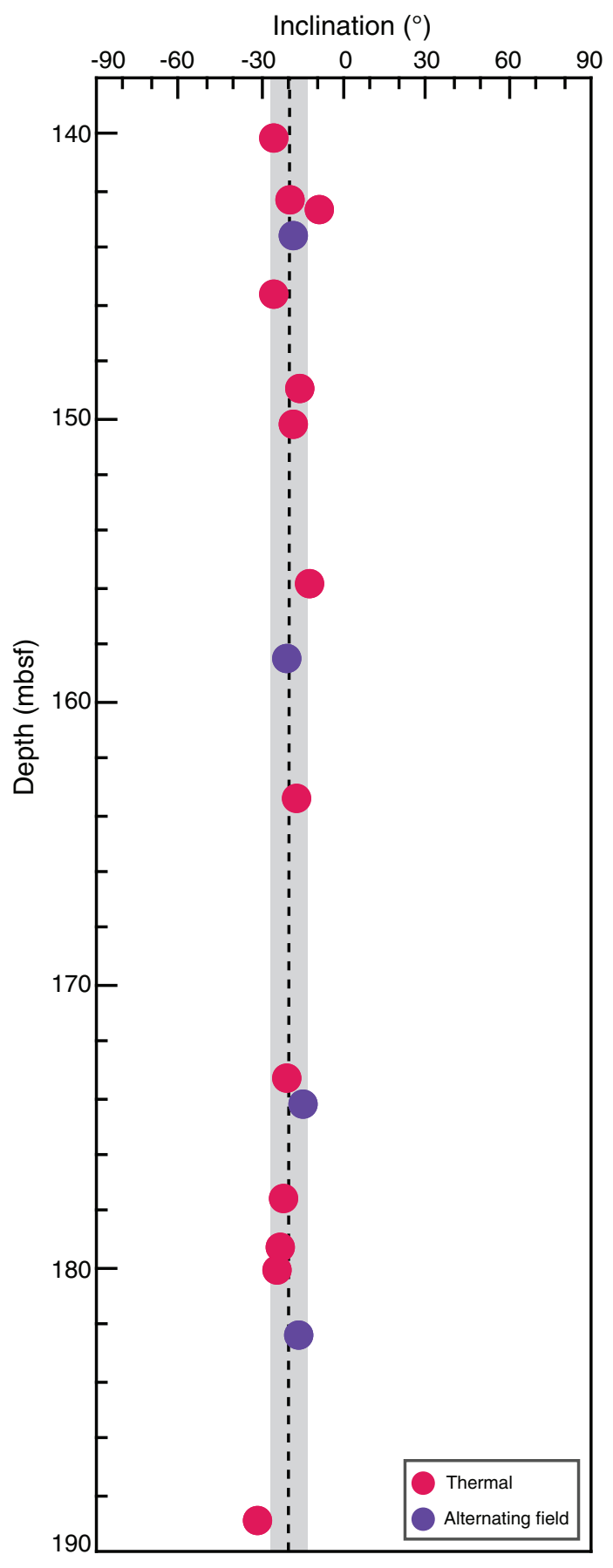


Figure F53. Downhole caliper, resistivity, and gamma ray logs, Hole U1346A. BHA = bottom-hole assembly. $\mathrm{IDPH}=$ deep induction phasor-processed resistivity, IMPH = medium induction phasor-processed resistivity, SFLU = spherically focused resistivity. HSGR = total spectral gamma ray, HCGR = computed gamma ray. TD = total depth.

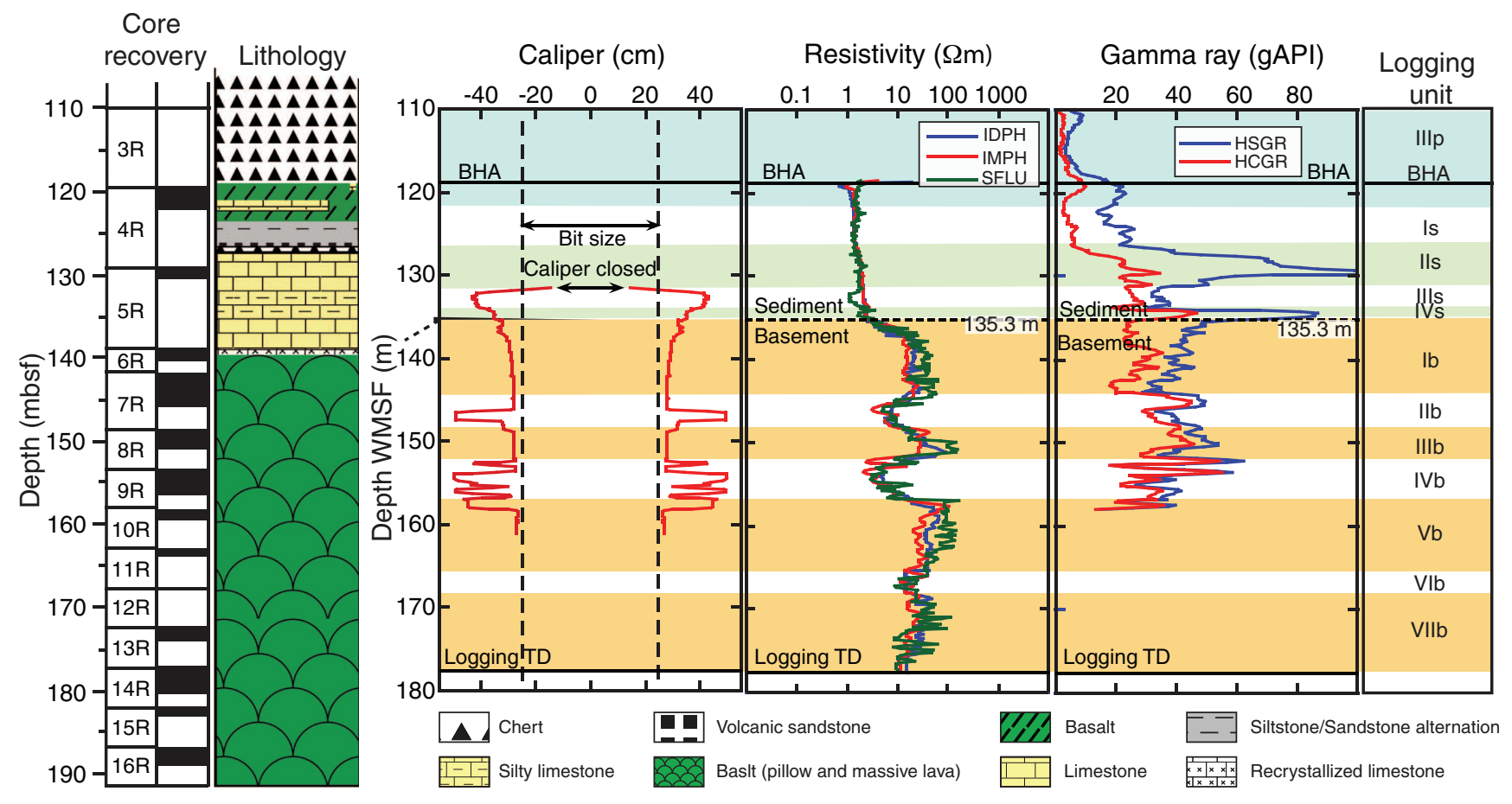


Figure F54. Whole-rock $\mathrm{K}_{2} \mathrm{O}$ elemental concentrations and downhole spectral gamma ray logs of uranium, potassium, and thorium, Hole U1346A. BHA = bottom-hole assembly, TD = total depth. Solid circles = whole-rock $\mathrm{K}_{2} \mathrm{O}$ elemental concentrations from ICP-AES measurements on core samples. HFK = gamma ray log potassium measurement.

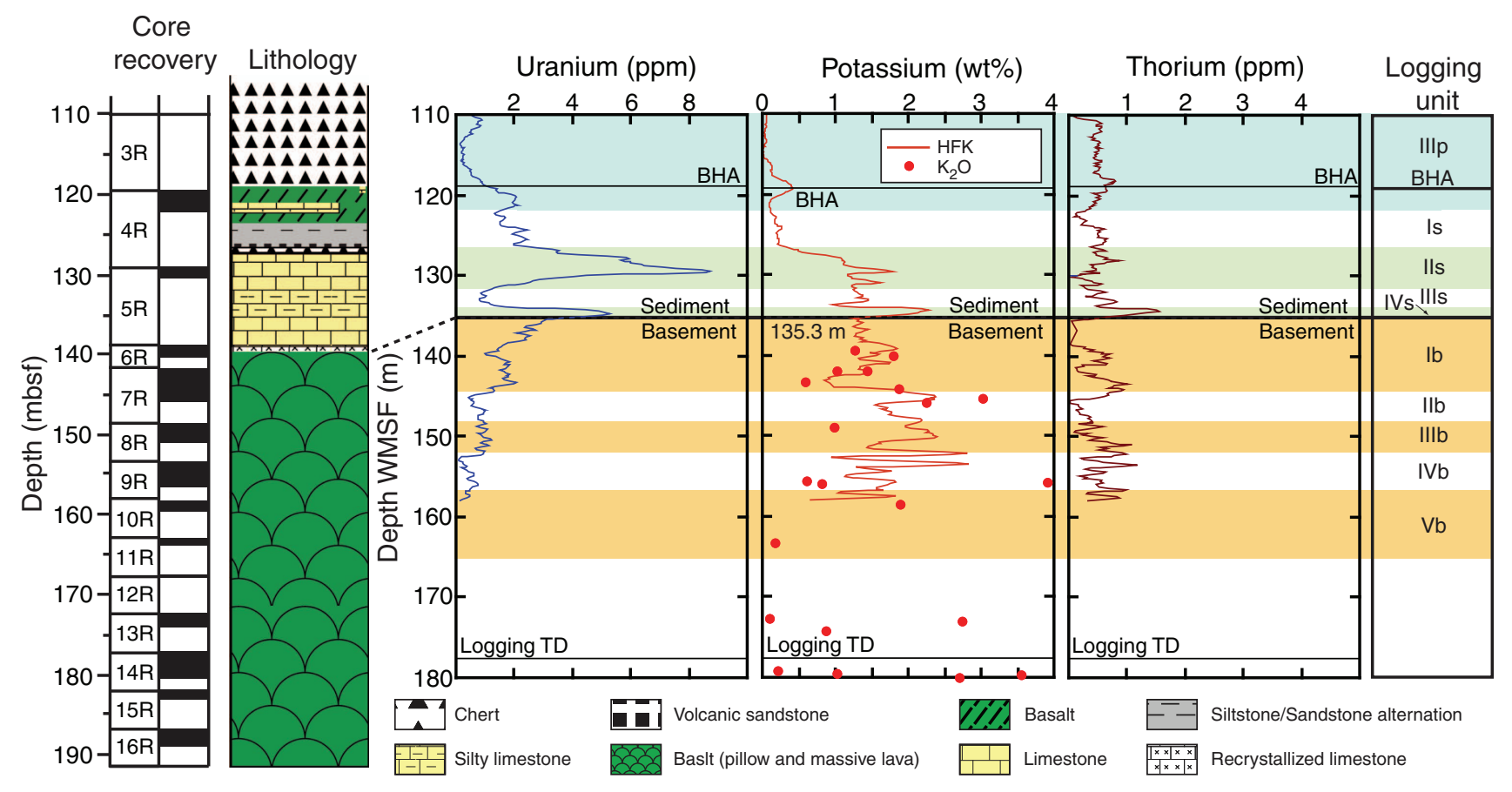


Figure F55. Downhole caliper, density, and photoelectric effect logs, Hole U1346A. BHA = bottom-hole assembly, HROM = high-resolution corrected bulk density, MAD = discrete sample density, TD = total depth.

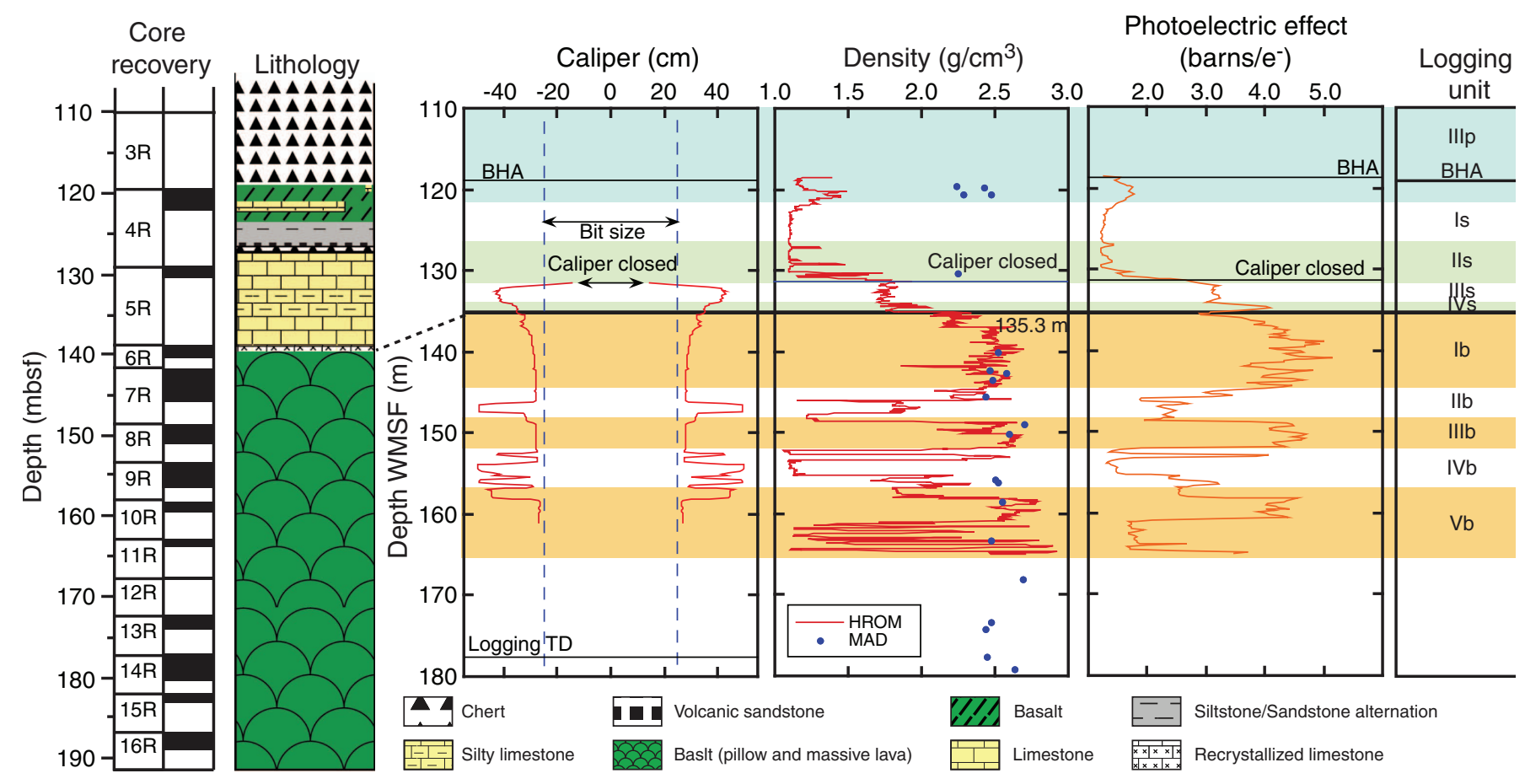


Figure F56. Downhole magnetic field logs, Hole U1346A. $\mathrm{F}_{x}, \mathrm{~F}_{y}, \mathrm{~F}_{z}=x-, y$-, and $z$-axis measurements, respectively.

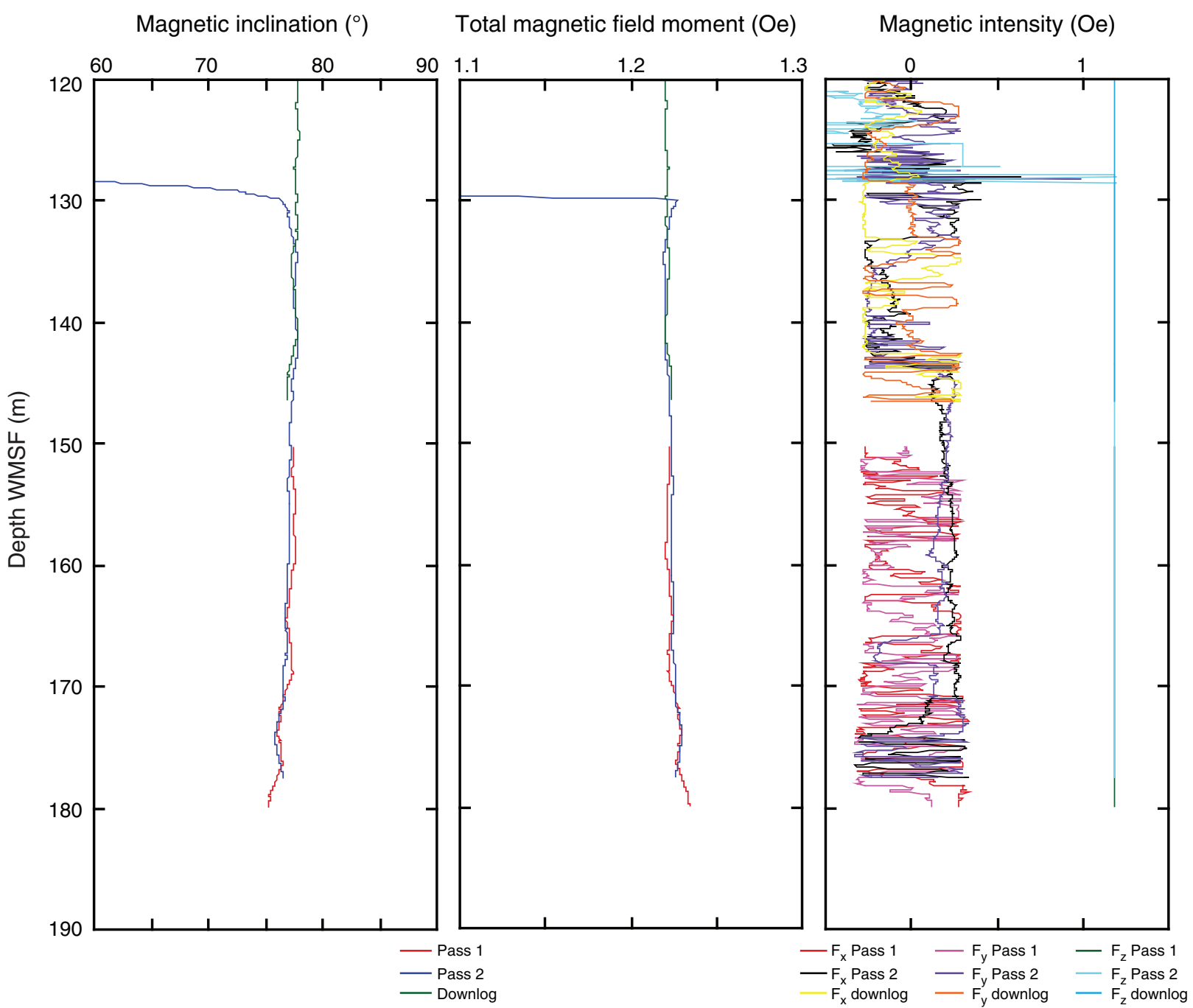


Figure F57. Downhole gamma ray logs through the pipe, Hole U1346A. BHA = bottom-hole assembly, TD = total depth, HSGR = gamma ray log, HCGR = computed gamma radiation.

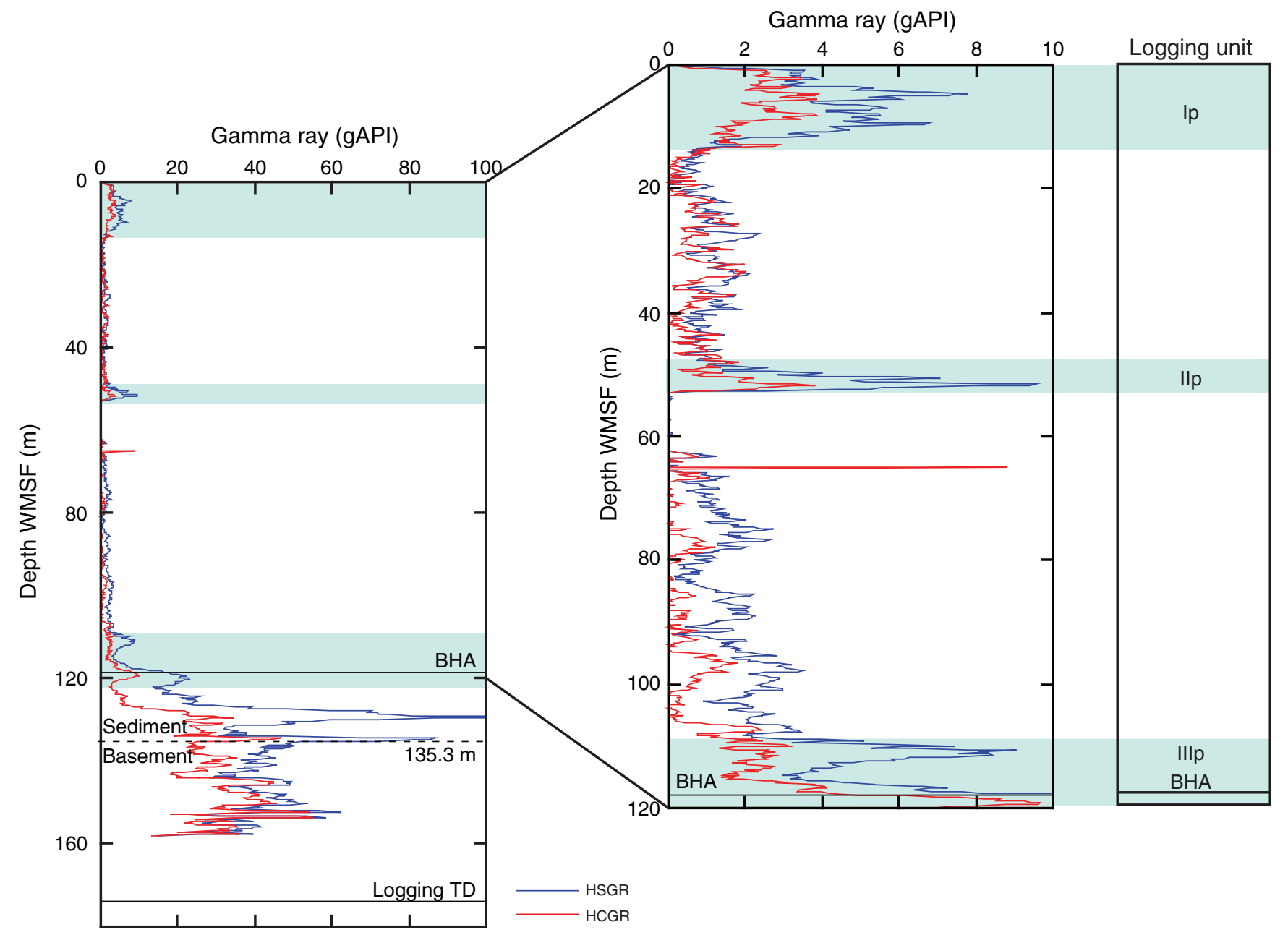


Figure F58. Downhole potassium mean value log from Hole U1346A compared to means from Hole 807C in the Ontong Java Plateau, Hole 1256D in the East Pacific Rise, and Hole U1301 in the Juan de Fuca Ridge.

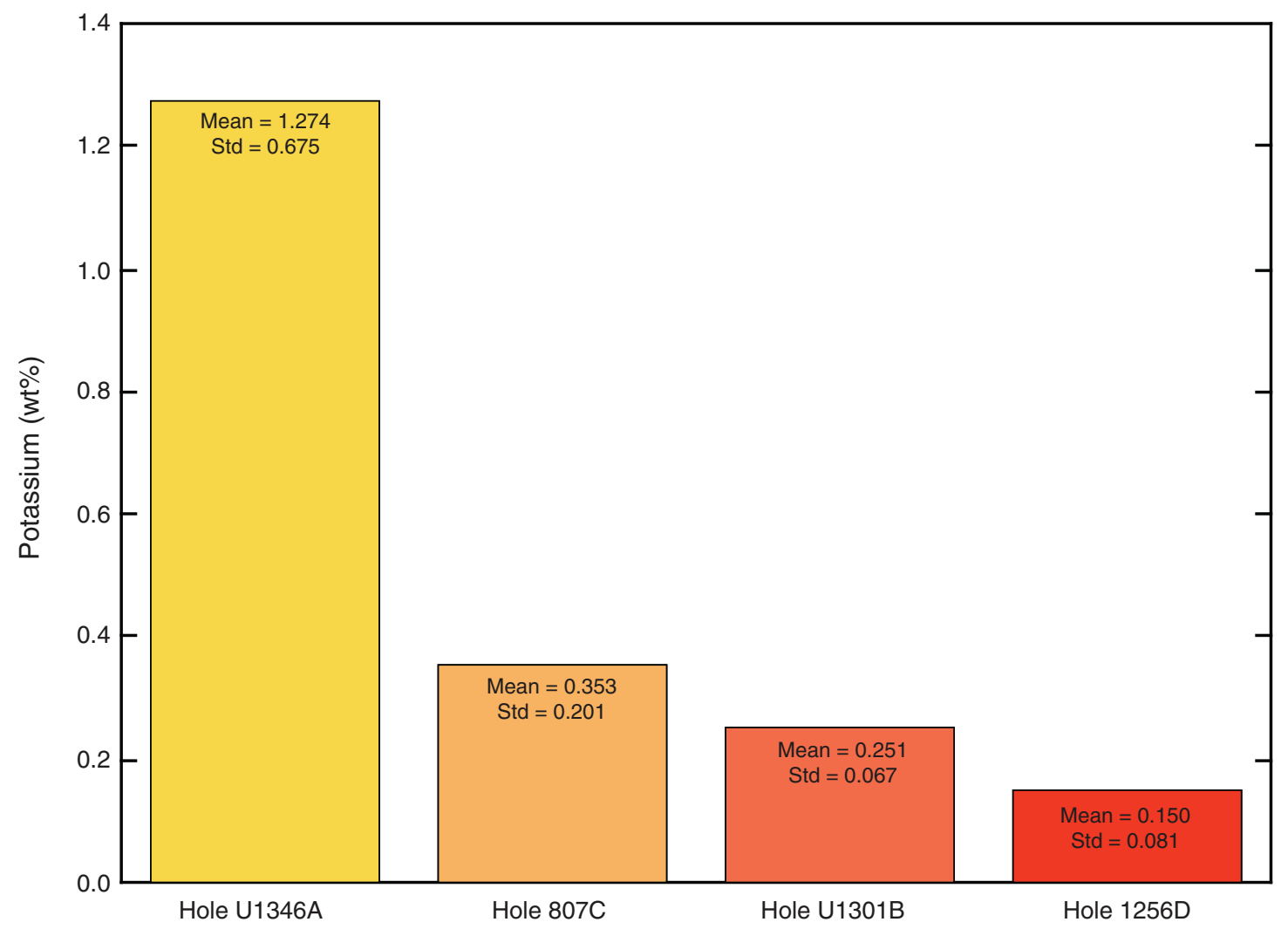


Figure F59. Gamma ray logs (HSGR), deep induction phasor-processed resistivity (IDPH), and medium induction phasor-processed resistivity (IMPH) with overlain seismic profile for Hole U1346A.

Hole U1346A

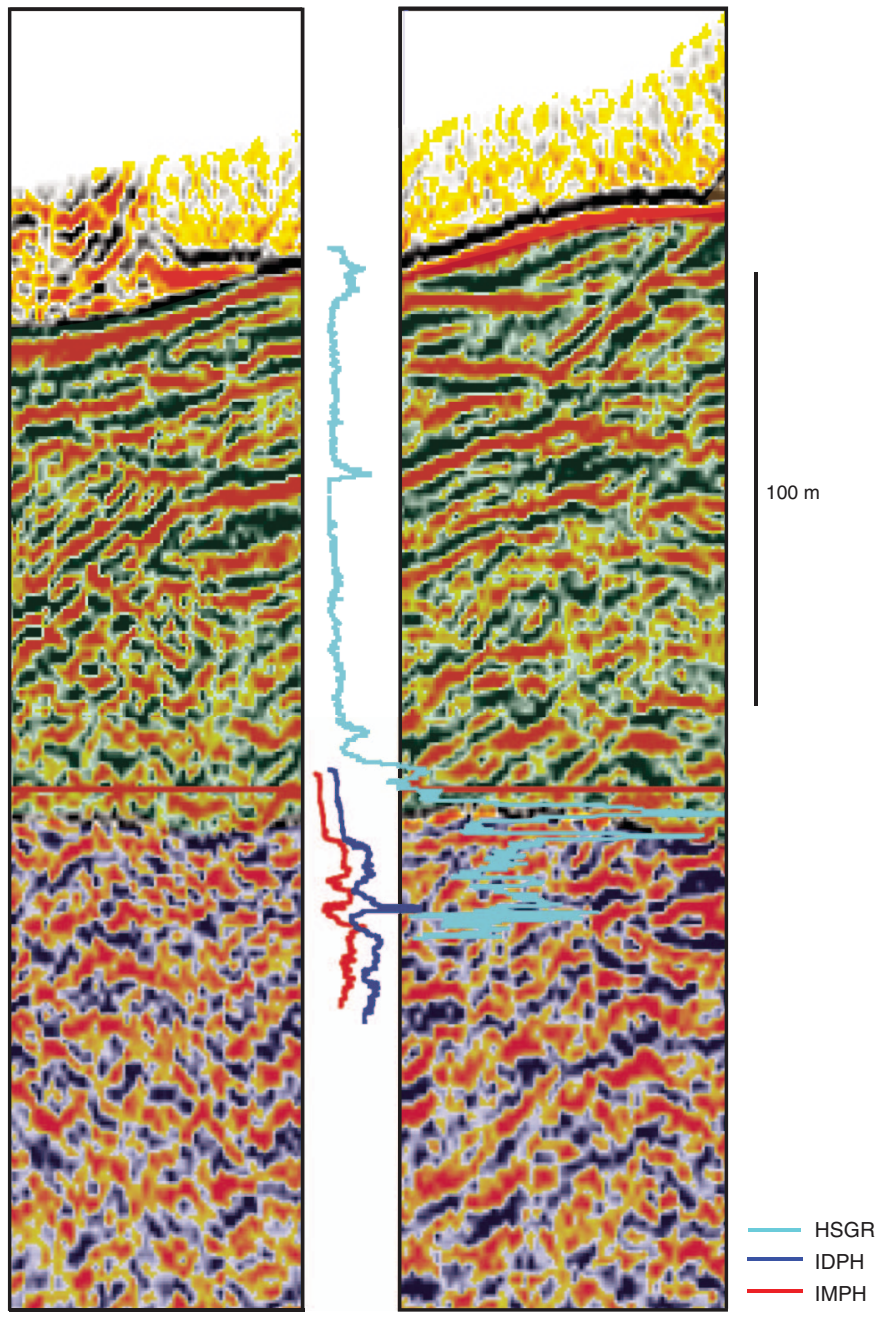


Table T1. Coring summary, Site U1346. (See table notes.)

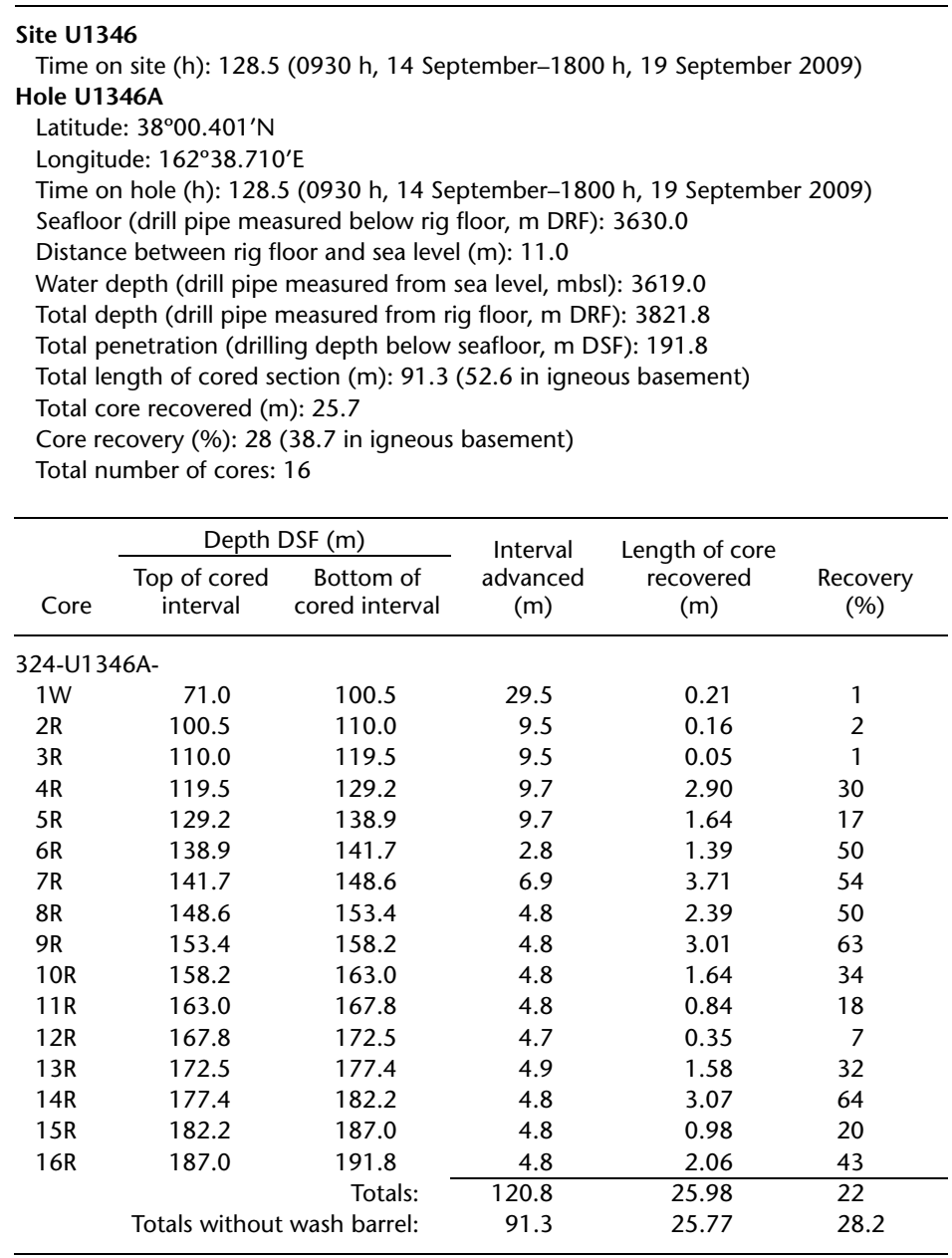

Notes: DRF $=$ drilling depth below rig floor, DSF $=$ drilling depth below seafloor. Local time $=\mathrm{UTC}+10 \mathrm{~h}$.

Table T2. Carbon content, Hole U1346A. (See table note.)

\begin{tabular}{lrrrr}
\hline $\begin{array}{c}\text { Core, section, } \\
\text { interval (cm) }\end{array}$ & $\begin{array}{c}\text { Depth } \\
\text { (mbsf) }\end{array}$ & $\begin{array}{c}\text { Total } \\
\text { carbon } \\
\text { (wt\%) }\end{array}$ & $\begin{array}{c}\text { Carbonate* } \\
\text { (wt\%) }\end{array}$ & $\begin{array}{l}\text { Organic } \\
\text { carbon } \\
\text { (wt\%) }\end{array}$ \\
\hline 324-U1346A- & & & & \\
4R-1, 96-97 & 120.43 & 11.5 & $93.3 \pm 1.2$ & 0.3 \\
4R-2, 61-63 & 121.26 & 0.6 & $3.5 \pm 0.2$ & 0.1 \\
4R-2, 140-143 & 122.05 & 12.2 & $98.4 \pm 0.8$ & 0.4 \\
5R-1, 12-13 & 129.32 & 12.3 & $88.4 \pm 0.4$ & 1.6 \\
5R-1, 96-97 & 130.16 & 3.7 & $27.8 \pm 0.4$ & 0.4 \\
5R-CC, 13-15 & 130.62 & 3.9 & $32.4 \pm 0.4$ & 0.4 \\
\hline
\end{tabular}

Note: ${ }^{*}= \pm 2 \sigma$. 
Table T3. Calcareous nannofossil age assignments, Site U1346. (See table notes.)

\begin{tabular}{|c|c|c|c|}
\hline $\begin{array}{l}\text { Core, section, } \\
\text { interval }(\mathrm{cm})\end{array}$ & Age-diagnostic species (Abundance) & Stratigraphic range (Zone) & $\begin{array}{c}\text { Age }(\mathrm{Ma}) \\
\text { (Range estimation) }\end{array}$ \\
\hline $\begin{array}{l}\text { 324-U1346A- } \\
\text { 2R-1, } 1\end{array}$ & $\begin{array}{l}\text { Cretarhabdus striatus (F) } \\
\text { Cruciellipsis cuvillieri (R) } \\
\text { Reinhardites levis (R) } \\
\text { Speetonia sp. (R) } \\
\text { Tubodiscus verenae (R) }\end{array}$ & $\begin{array}{l}\text { Aptian-upper Cenomanian (?-UC4) } \\
\text { Tithonian-Hauterivian (NJ18-NC5) } \\
\text { upper Campanian-Maastrichtian (?-CC25/UC19) } \\
\text { Berriasian-Hauterivian (NK3-NC5) } \\
\text { Valanginian (NK3b-NC4) }\end{array}$ & (Cretaceous) \\
\hline $4 \mathrm{R}-2,27-30$ & $\begin{array}{l}\text { Cretarhabdus striatus (C) } \\
\text { Eprolithus antiquus }(\mathrm{R}) \\
\text { Nannoconus steinmannii spp. minor (R) } \\
\text { Reinhardites levis (R) }\end{array}$ & $\begin{array}{l}\text { Aptian-upper Cenomanian (?-UC4) } \\
\text { Hauterivian (NK3b-NC4a) } \\
\text { Berriasian-Valanginian (NJKc-?) } \\
\text { upper Campanian-Maastrichtian (?-CC25/UC19) }\end{array}$ & (Cretaceous) \\
\hline $4 \mathrm{R}-2,107-108$ & $\begin{array}{l}\text { Cretarhabdus striatus (R) } \\
\text { Eprolithus antiquus (R) } \\
\text { Nannoconus sp. }\end{array}$ & $\begin{array}{l}\text { Aptian-upper Cenomanian (?-UC4) } \\
\text { Hauterivian (NK3b-NC4a) } \\
\text { Berriasian-Cenomanian }\end{array}$ & (Cretaceous) \\
\hline $4 \mathrm{R}-2,140-143$ & Eprolithus antiquus (R) & Hauterivian (NK3b-NC4a) & $133.1-131.2$ \\
\hline $4 \mathrm{R}-\mathrm{CC}, 3$ & $\begin{array}{l}\text { Eprolithus antiquus }(\mathrm{C}) \\
\text { Haqius circumradiatus }(\mathrm{F}) \\
\text { Nannoconus steinmannii spp. minor (R) }\end{array}$ & $\begin{array}{l}\text { Hauterivian (NK3b-NC4a) } \\
\text { Hauterivian-Campanian (?-UC15c) } \\
\text { Berriasian-Valanginian (NJKc-?) }\end{array}$ & (Early Cretaceous) \\
\hline $5 R-1,3-4$ & $\begin{array}{l}\text { Eprolithus antiquus (R) } \\
\text { Cretarhabdus striatus (R) } \\
\text { Nannoconus sp. }\end{array}$ & $\begin{array}{l}\text { Hauterivian (NK3b-NC4a) } \\
\text { Aptian-upper Cenomanian (?-UC4) } \\
\text { Berriasian-Cenomanian }\end{array}$ & (Cretaceous) \\
\hline $5 R-1,16-17$ & $\begin{array}{l}\text { Cretarhabdus striatus (R) } \\
\text { Haqius circumradiatus (R) } \\
\text { Speetonia sp. (R) }\end{array}$ & $\begin{array}{l}\text { Aptian-upper Cenomanian (?-UC4) } \\
\text { Hauterivian-Campanian (?-UC15c) } \\
\text { Berriasian-Hauterivian (NK3-NC5) }\end{array}$ & (Cretaceous) \\
\hline $5 R-1,53-54$ & $\begin{array}{l}\text { Haqius circumradiatus (F) } \\
\text { Nannoconus sp. } \\
\text { Rotelapillius laffittei (R) } \\
\text { Speetonia } \mathrm{sp} .(\mathrm{R})\end{array}$ & $\begin{array}{l}\text { Hauterivian-Campanian (?-UC15c) } \\
\text { Berriasian-Cenomanian } \\
\text { Berriasian-Turonian (NJKd-UC9) } \\
\text { Berriasian-Hauterivian (NK3-NC5) }\end{array}$ & $137.7-128.3$ \\
\hline $5 R-1,91-92$ & $\begin{array}{l}\text { Cruciellipsis cuvillieri (R) } \\
\text { Haqius circumradiatus (F) }\end{array}$ & $\begin{array}{l}\text { Tithonian-Hauterivian (NJ18-NC5) } \\
\text { Hauterivian-Campanian (?-UC15C) }\end{array}$ & (Hauterivian) \\
\hline 5R-CC, 24-25 & $\begin{array}{l}\text { Eprolithus antiquus }(\mathrm{C}) \\
\text { Haqius circumradiatus }(\mathrm{F}) \\
\text { Micrantholithus hochschulzi (R) }\end{array}$ & $\begin{array}{l}\text { Hauterivian (NK3b-NC4a) } \\
\text { Hauterivian-Campanian (?-UC15c) } \\
\text { Berriasian-Aptian }\end{array}$ & $133.1-131.2$ \\
\hline
\end{tabular}

Notes: Abundance: $\mathrm{C}=$ common, $\mathrm{F}=$ frequent, $\mathrm{R}=$ rare. Zone ranges are only given for properly defined taxa.

Table T4. Benthic foraminifer preservation and abundance, Site U1346. (See table notes.)

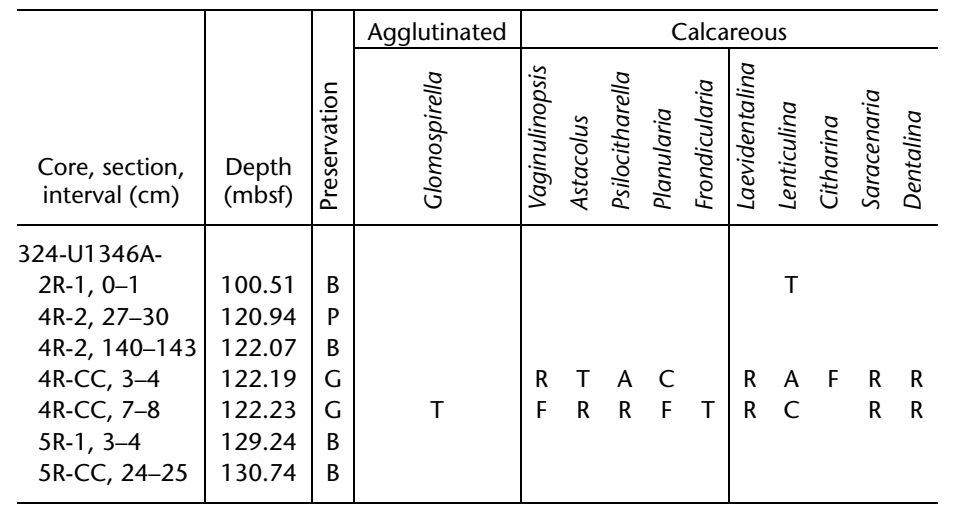

Notes: Preservation: $\mathrm{G}=$ good, $\mathrm{P}=$ poor, $\mathrm{B}=$ barren. Abundance: $\mathrm{A}=$ abundant, $\mathrm{C}=$ common, $\mathrm{F}=$ few, $\mathrm{R}=$ rare, $\mathrm{T}=$ trace. See "Paleontology" in the "Methods" chapter for preservation and abundance descriptions. For all samples, $>125 \mu \mathrm{m}$ fractions were examined. 
Table T5. Hierarchy of eruptive stacking.

\begin{tabular}{|c|c|c|c|}
\hline & \multicolumn{3}{|c|}{ Observation } \\
\hline & Macro scale & Intermediate & Meso scale \\
\hline Observation scale & $\sim 10$ to $>100 \mathrm{~m}$ & $\sim 2-50 \mathrm{~m}$ & $\sim 0.5-5 \mathrm{~m}$ \\
\hline Observation & Stacked lava packages & Stacked pillows & Individual pillow (inflation unit) \\
\hline Nomenclature & Single eruptive event (SEE) & Lava package (flow unit) & Lava unit \\
\hline
\end{tabular}

Table T6. Original microphenocryst abundances in Unit II and V basalts, Site U1346. (See table notes.)

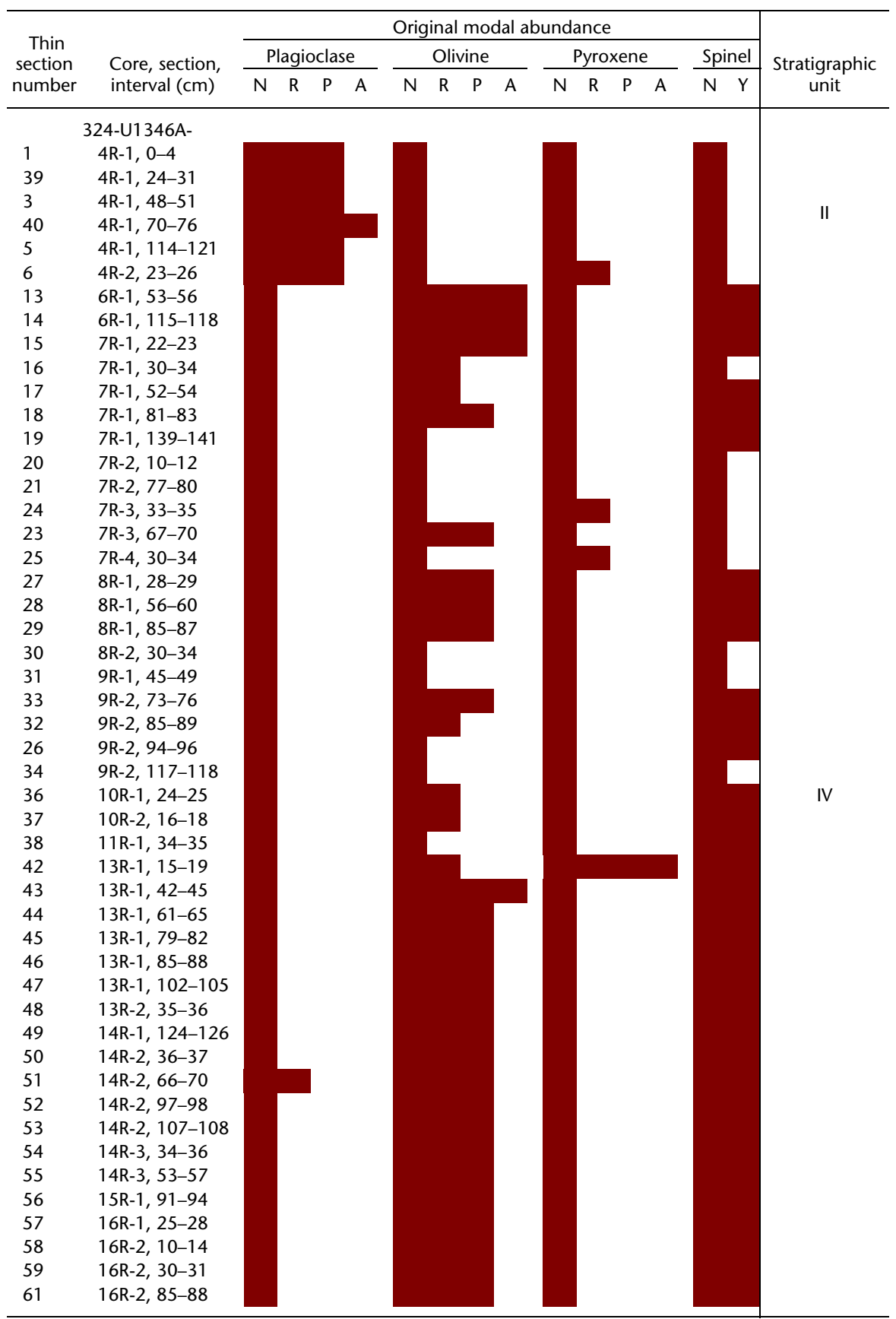

Notes: Estimated from thin sections. $\mathrm{N}=$ not present $(0 \%), \mathrm{R}=$ rare $(<1 \%), \mathrm{P}=$ present $(1 \%-5 \%), \mathrm{A}=$ abundant $(>5 \%), \mathrm{Y}=$ observed. 
Table T7. Whole-rock major and trace element compositions, Hole U1346A. (See table notes.) (Continued on next page.)

\begin{tabular}{|c|c|c|c|c|c|c|c|c|c|c|c|c|c|c|}
\hline \multirow[b]{2}{*}{ Core: } & \multicolumn{14}{|c|}{ 324-U1346A- } \\
\hline & $6 \mathrm{R}$ & $6 \mathrm{R}$ & $7 R$ & $7 R$ & $7 R$ & $7 R$ & $7 \mathrm{R}$ & $7 R$ & $8 \mathrm{R}$ & $9 \mathrm{R}$ & $9 \mathrm{R}$ & $9 \mathrm{R}$ & $10 \mathrm{R}$ & $11 R$ \\
\hline Section: & 1 & 1 & 1 & 1 & 2 & 2 & 3 & 4 & 1 & 2 & 2 & 2 & 1 & 1 \\
\hline Piece: & 6 & 13 & 2 & 3 & 1 & 7 & 7 & 2 & 2 & 7 & 7 & 8 & 4 & 6 \\
\hline Interval $(\mathrm{cm})$ : & $51-53$ & $115-118$ & $20-22$ & $28-30$ & $12-15$ & $104-107$ & $70-71$ & $31-34$ & $25-28$ & $73-76$ & $85-88$ & $116-119$ & $25-27$ & $31-34$ \\
\hline Top depth (mbsf): & 139.40 & 140.04 & 141.90 & 141.98 & 143.23 & 144.14 & 145.31 & 145.78 & 148.85 & 155.56 & 155.68 & 155.99 & 158.44 & 163.31 \\
\hline \multicolumn{15}{|c|}{ Major element oxide (wt\%): } \\
\hline $\mathrm{SiO}_{2}$ & 45.27 & 44.07 & 42.83 & 11.07 & 48.86 & 18.91 & 47.65 & 48.95 & 39.74 & 41.04 & 51.92 & 44.28 & 40.88 & 47.74 \\
\hline $\mathrm{TiO}_{2}$ & 1.53 & 1.52 & 1.54 & 0.28 & 1.64 & 0.09 & 1.63 & 1.61 & 1.43 & 1.48 & 1.69 & 1.52 & 1.56 & 1.46 \\
\hline $\mathrm{Al}_{2} \mathrm{O}_{3}$ & 16.74 & 15.95 & 16.49 & 3.75 & 17.39 & 5.62 & 17.63 & 17.38 & 14.31 & 15.78 & 15.34 & 16.16 & 15.74 & 15.47 \\
\hline $\mathrm{Fe}_{2} \mathrm{O}_{3}^{\top}$ & 9.65 & 7.17 & 8.21 & 8.95 & 10.32 & 9.74 & 7.62 & 9.74 & 9.75 & 8.01 & 13.03 & 8.75 & 8.00 & 10.88 \\
\hline $\mathrm{MnO}$ & 0.04 & 0.09 & 0.12 & 0.53 & 0.05 & 0.26 & 0.09 & 0.06 & 0.10 & 0.10 & 0.05 & 0.10 & 0.15 & 0.10 \\
\hline $\mathrm{MgO}$ & 5.98 & 4.22 & 5.34 & 1.69 & 7.81 & 2.83 & 4.91 & 6.82 & 5.81 & 6.15 & 8.77 & 6.92 & 5.44 & 10.11 \\
\hline $\mathrm{CaO}$ & 10.00 & 18.40 & 21.71 & 57.56 & 8.57 & 55.36 & 14.74 & 9.38 & 22.15 & 19.74 & 3.76 & 19.83 & 22.44 & 8.78 \\
\hline $\mathrm{Na}_{2} \mathrm{O}$ & 2.90 & 2.45 & 2.49 & B.D. & 3.09 & 0.50 & 2.77 & 2.96 & 2.28 & 2.53 & 2.63 & 2.78 & 2.39 & 2.76 \\
\hline $\mathrm{K}_{2} \mathrm{O}$ & 1.18 & 1.72 & 1.02 & 1.22 & 0.58 & 1.77 & 3.03 & 2.22 & 0.95 & 0.57 & 3.95 & 0.83 & 1.85 & 0.17 \\
\hline $\mathrm{P}_{2} \mathrm{O}_{5}$ & 0.20 & 0.20 & 0.14 & 0.03 & 0.15 & 0.10 & 0.44 & 0.19 & 0.19 & 0.15 & 0.15 & 0.19 & 0.21 & 0.14 \\
\hline Totals: & 93.50 & 95.80 & 99.89 & 85.09 & 98.46 & 95.18 & 100.51 & 99.31 & 96.72 & 95.55 & 101.28 & 101.36 & 98.66 & 97.61 \\
\hline LOI (wt\%) & 11.96 & 13.85 & 10.52 & 30.97 & 5.10 & 34.34 & 11.05 & 8.33 & 10.58 & 10.90 & 6.50 & 11.22 & 13.79 & 5.14 \\
\hline \multicolumn{15}{|c|}{ Major element oxide (wt\%) normalized to 100 wt\%: } \\
\hline $\mathrm{SiO}_{2}$ & 48.42 & 46.00 & 42.88 & 13.01 & 49.62 & 19.87 & 47.41 & 49.29 & 41.09 & 42.95 & 51.26 & 43.69 & 41.44 & 48.90 \\
\hline $\mathrm{TiO}_{2}$ & 1.64 & 1.59 & 1.54 & 0.33 & 1.66 & 0.10 & 1.63 & 1.62 & 1.47 & 1.54 & 1.67 & 1.50 & 1.58 & 1.50 \\
\hline $\mathrm{Al}_{2} \mathrm{O}_{3}$ & 17.91 & 16.65 & 16.51 & 4.41 & 17.66 & 5.90 & 17.54 & 17.50 & 14.80 & 16.51 & 15.15 & 15.94 & 15.95 & 15.85 \\
\hline $\mathrm{Fe}_{2} \mathrm{O}_{3}^{\top}$ & 10.32 & 7.48 & 8.22 & 10.52 & 10.48 & 10.23 & 7.58 & 9.81 & 10.08 & 8.39 & 12.86 & 8.64 & 8.11 & 11.14 \\
\hline $\mathrm{MnO}$ & 0.04 & 0.10 & 0.12 & 0.62 & 0.05 & 0.27 & 0.09 & 0.06 & 0.11 & 0.10 & 0.05 & 0.10 & 0.15 & 0.10 \\
\hline $\mathrm{MgO}$ & 6.40 & 4.41 & 5.35 & 1.99 & 7.93 & 2.97 & 4.88 & 6.87 & 6.01 & 6.44 & 8.66 & 6.83 & 5.51 & 10.36 \\
\hline $\mathrm{CaO}$ & 10.70 & 19.21 & 21.73 & 67.64 & 8.71 & 58.17 & 14.67 & 9.45 & 22.91 & 20.66 & 3.72 & 19.56 & 22.74 & 9.00 \\
\hline $\mathrm{Na}_{2} \mathrm{O}$ & 3.10 & 2.56 & 2.49 & $\mathrm{BD}$ & 3.14 & 0.52 & 2.75 & 2.98 & 2.36 & 2.65 & 2.59 & 2.74 & 2.43 & 2.82 \\
\hline $\mathrm{K}_{2} \mathrm{O}$ & 1.27 & 1.80 & 1.02 & 1.44 & 0.59 & 1.86 & 3.01 & 2.24 & 0.98 & 0.60 & 3.90 & 0.81 & 1.88 & 0.17 \\
\hline $\mathrm{P}_{2} \mathrm{O}_{5}$ & 0.21 & 0.21 & 0.14 & 0.04 & 0.15 & 0.11 & 0.44 & 0.19 & 0.20 & 0.16 & 0.14 & 0.19 & 0.21 & 0.15 \\
\hline Totals: & 100.00 & 100.00 & 100.00 & 100.00 & 100.00 & 100.00 & 100.00 & 100.00 & 100.00 & 100.00 & 100.00 & 100.00 & 100.00 & 100.00 \\
\hline $\mathrm{Mg} \#$ & 59.1 & 57.8 & 60.2 & 30.5 & 63.8 & 40.3 & 60.0 & 62.0 & 58.1 & 64.1 & 61.0 & 64.8 & 61.3 & 68.4 \\
\hline \multicolumn{15}{|l|}{ Trace element (ppm): } \\
\hline $\mathrm{Ba}$ & 46 & 50 & 46 & 15 & 31 & 15 & 67 & 54 & 29 & 35 & 55 & 36 & 63 & 23 \\
\hline $\mathrm{Sr}$ & 268 & 282 & 315 & 140 & 272 & 277 & 287 & 256 & 315 & 337 & 207 & 343 & 293 & 242 \\
\hline $\mathrm{Zr}$ & 80 & 75 & 76 & 27 & 82 & 29 & 80 & 81 & 75 & 74 & 75 & 75 & 77 & 73 \\
\hline $\mathrm{Y}$ & 22 & 23 & 24 & 23 & 21 & 16 & 30 & 23 & 24 & 26 & 25 & 24 & 26 & 27 \\
\hline V & 306 & 304 & 301 & 121 & 321 & 162 & 345 & 322 & 293 & 283 & 327 & 314 & 279 & 281 \\
\hline Sc & 41 & 40 & 41 & 15 & 45 & 11 & 42 & 42 & 37 & 38 & 42 & 40 & 40 & 38 \\
\hline $\mathrm{Cu}$ & 118 & 150 & 128 & 25 & 123 & 22 & 142 & 126 & 137 & 132 & 36 & 123 & 141 & 106 \\
\hline $\mathrm{Zn}$ & 69 & 80 & 95 & 11 & 78 & 21 & 98 & 93 & 70 & 75 & 103 & 75 & 91 & 73 \\
\hline Co & 54 & 54 & 55 & 14 & 53 & 6 & 92 & 64 & 47 & 60 & 31 & 76 & 61 & 46 \\
\hline $\mathrm{Cr}$ & 315 & 284 & 311 & 62 & 352 & 42 & 320 & 323 & 260 & 291 & 342 & 337 & 295 & 309 \\
\hline $\mathrm{Ni}$ & 175 & 127 & 168 & 15 & 143 & 27 & 294 & 255 & 142 & 181 & 36 & 156 & 127 & 128 \\
\hline
\end{tabular}

Notes: All analyses were conducted on samples ignited to $975^{\circ} \mathrm{C}$. $\mathrm{Fe}_{2} \mathrm{O}_{3}{ }^{\top}=$ total iron expressed as $\mathrm{Fe}_{2} \mathrm{O}_{3}$. LOI $=$ weight loss on ignition. $\mathrm{Mg \#}=$ $100 \times\left(\mathrm{Mg}^{2+} /\left[\mathrm{Mg}^{2+}+\mathrm{Fe}^{2+}\right]\right)$, assuming that $\mathrm{Fe}_{2} \mathrm{O}_{3} / \mathrm{FeO}=0.15 . \mathrm{BD}=$ below detection. 
Table T7 (continued).

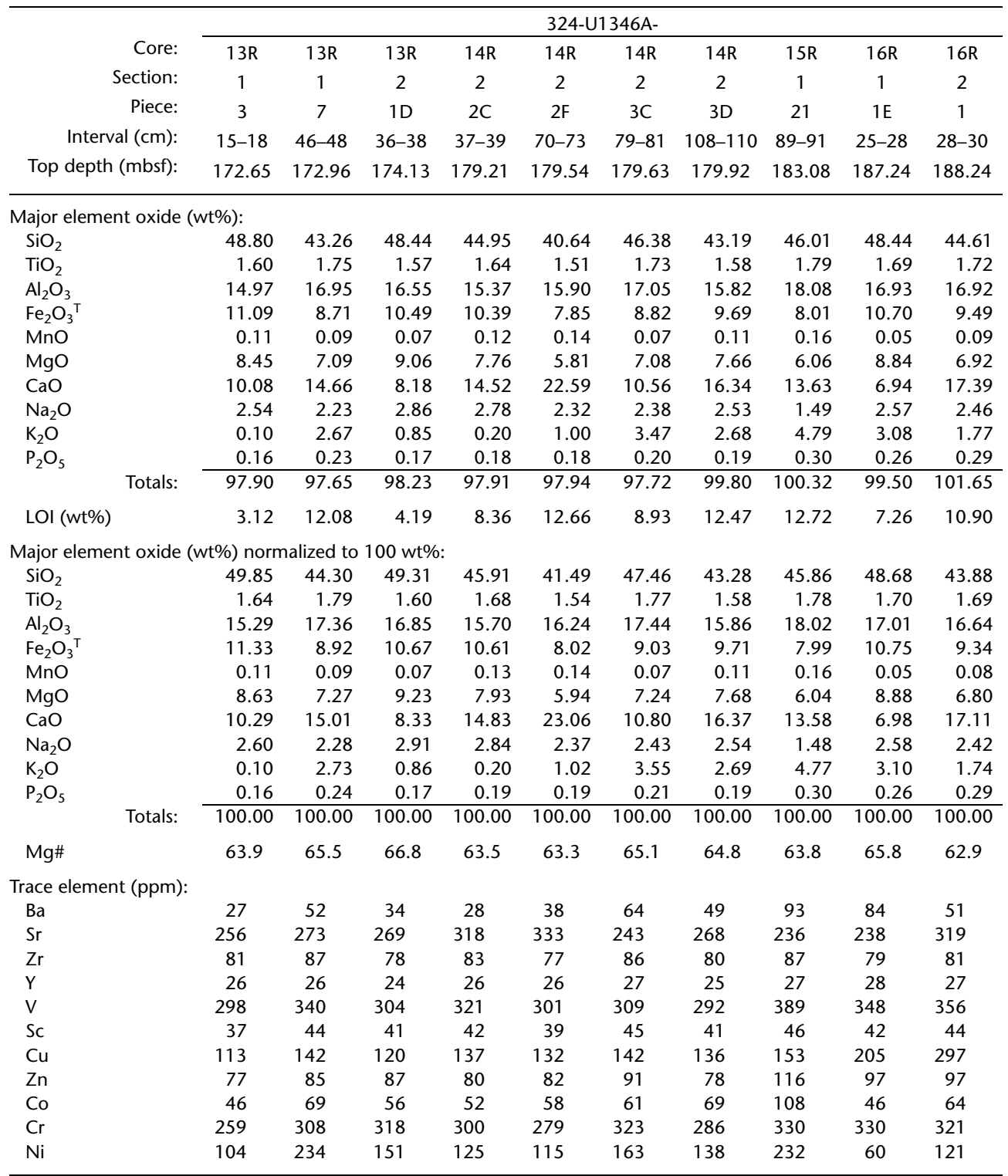


Table T8. Moisture and density measurements, Site U1346. (See table notes.)

\begin{tabular}{|c|c|c|c|c|c|c|c|}
\hline \multirow{2}{*}{$\begin{array}{l}\text { Core, section, } \\
\text { interval }(\mathrm{cm})\end{array}$} & \multirow{2}{*}{$\begin{array}{l}\text { Top depth } \\
\text { (mbsf) }\end{array}$} & \multicolumn{3}{|c|}{ Density $\left(\mathrm{g} / \mathrm{cm}^{3}\right)$} & \multirow{2}{*}{$\begin{array}{l}\text { Void } \\
\text { ratio }\end{array}$} & \multirow{2}{*}{$\begin{array}{c}\text { Water } \\
\text { content (\%) }\end{array}$} & \multirow{2}{*}{$\begin{array}{l}\text { Porosity } \\
\text { (\%) }\end{array}$} \\
\hline & & Bulk & Dry & Grain & & & \\
\hline \multicolumn{8}{|l|}{ 324-U1346A- } \\
\hline $4 R-1,4-6$ & 119.54 & 2.233 & 1.885 & 2.853 & 0.513 & 15.55 & 33.91 \\
\hline $4 \mathrm{R}-1,15-17$ & 119.65 & 2.429 & 2.233 & 2.761 & 0.236 & 8.06 & 19.12 \\
\hline 4R-1, 104-106 & 120.54 & 2.472 & 2.324 & 2.718 & 0.170 & 6.01 & 14.50 \\
\hline $4 R-1,112-114$ & 120.62 & 2.282 & 2.818 & 2.818 & 0.426 & $13.41^{*}$ & 29.88 \\
\hline 5R-1, 117-119 & 130.37 & 2.247 & 1.956 & 2.732 & 0.396 & 12.94 & 28.39 \\
\hline $6 \mathrm{R}-1,111-113$ & 140.01 & 2.516 & 2.377 & 2.750 & 0.157 & 5.52 & 13.57 \\
\hline $7 R-1,53-55$ & 142.24 & 2.460 & 2.284 & 2.758 & 0.208 & 7.17 & 17.21 \\
\hline 7R-1, 92-94 & 142.62 & 2.573 & 2.444 & 2.796 & 0.144 & 5.01 & 12.58 \\
\hline 7R-2, 39-41 & 143.50 & 2.481 & 2.289 & 2.817 & 0.231 & 7.74 & 18.75 \\
\hline $7 R-4,12-14$ & 145.59 & 2.434 & 2.227 & 2.791 & 0.253 & 8.50 & 20.20 \\
\hline $8 \mathrm{R}-1,29-31$ & 148.90 & 2.696 & 2.614 & 2.843 & 0.088 & 3.07 & 8.08 \\
\hline $8 R-2,11-13$ & 150.13 & 2.594 & 2.509 & 2.734 & 0.090 & 3.25 & 8.23 \\
\hline 9R-2, 107.5-109.5 & 155.78 & 2.500 & 2.294 & 2.872 & 0.252 & 8.23 & 20.10 \\
\hline $9 R-2,127.5-129.5$ & 156.10 & 2.523 & 2.361 & 2.806 & 0.189 & 6.44 & 15.86 \\
\hline 10R-1, 21.5-23.5 & 158.42 & 2.548 & 2.417 & 2.771 & 0.147 & 5.14 & 12.78 \\
\hline 11R-1, 35-37 & 163.35 & 2.468 & 2.242 & 2.875 & 0.282 & 9.13 & 22.01 \\
\hline $12 \mathrm{R}-2,2-4$ & 168.06 & 2.687 & 2.546 & 2.952 & 0.159 & 5.24 & 13.75 \\
\hline 13R-1, 76-78 & 173.26 & 2.472 & 2.320 & 2.725 & 0.174 & 6.15 & 14.85 \\
\hline 13R-2, 38-41 & 174.15 & 2.436 & 2.220 & 2.813 & 0.267 & 8.86 & 21.08 \\
\hline $14 \mathrm{R}-1,14-16$ & 177.54 & 2.447 & 2.288 & 2.709 & 0.184 & 6.50 & 15.53 \\
\hline $14 \mathrm{R}-2,32-34$ & 179.16 & 2.634 & 2.523 & 2.828 & 0.121 & 4.19 & 10.77 \\
\hline $14 \mathrm{R}-2,121-123$ & 180.05 & 2.441 & 2.253 & 2.760 & 0.225 & 7.72 & 18.39 \\
\hline 15R-1, 7-9 & 182.26 & 2.457 & 2.290 & 2.736 & 0.195 & 6.79 & 16.29 \\
\hline $16 \mathrm{R}-1,41-43$ & 187.41 & 2.487 & 2.281 & 2.855 & 0.251 & 8.27 & 20.09 \\
\hline 16R-2, 89-91 & 188.85 & 2.483 & 2.328 & 2.743 & 0.178 & 6.23 & 15.11 \\
\hline
\end{tabular}

Notes: * = cube was irregular and water content determined by Method D. All other determinations by Method C. See "Moisture and density calculations" in the "Methods" chapter for method descriptions. Water content is relative to wet mass.

Table T9. Compressional wave velocity measurements, Site U1346. (See table note.)

\begin{tabular}{lcccc}
\hline \multirow{2}{*}{$\begin{array}{c}\text { Core, section, } \\
\text { interval }(\mathrm{cm})\end{array}$} & \multirow{2}{*}{$\begin{array}{c}\text { Top depth } \\
\text { (mbsf) }\end{array}$} & x-direction & $y$-direction & z-direction \\
\cline { 5 - 6 } 324-U1346A- & & & & \\
4R-1, 4-6 & 119.54 & 3.51 & 3.56 & 3.46 \\
4R-1, 15-17 & 119.65 & 4.63 & 4.66 & 4.59 \\
4R-1, 104-106 & 120.54 & 4.76 & 4.62 & 4.59 \\
4R1-1, 112-114 & 120.62 & 3.77 & 3.65 & 3.77 \\
5R1-1, 117-119 & 130.37 & 3.83 & 3.93 & 3.77 \\
6R-1, 111-113 & 140.01 & 4.72 & 4.76 & 4.77 \\
7R-1, 53-55 & 142.24 & 4.54 & 4.65 & 4.62 \\
7R-1,92-94 & 142.62 & 4.98 & 4.97 & 4.91 \\
7R-2, 39-41 & 143.50 & 4.42 & 4.44 & 4.41 \\
7R-4, 12-14 & 145.59 & 4.25 & 4.23 & 4.23 \\
8R-1, 29-31 & 148.90 & 5.68 & 5.62 & 5.62 \\
8R-2, 11-13 & 150.13 & 5.45 & 5.44 & 5.44 \\
9R-2, 107.5-109.5 & 155.78 & 4.28 & 4.27 & 4.27 \\
9R-2, 127.5-129.5 & 156.10 & 4.86 & 4.83 & 4.83 \\
10R-1, 21.5-23.5 & 158.42 & 5.03 & 4.98 & 5.11 \\
11R-1, 35-37 & 163.35 & 4.10 & 4.12 & 4.15 \\
12R-2, 2-4 & 168.06 & 4.93 & 4.89 & 4.86 \\
13R-1, 76-78 & 173.26 & 4.61 & 4.64 & 4.60 \\
13R-2, 38-41 & 174.15 & 4.27 & 4.14 & 4.27 \\
14R-1, 14-16 & 177.54 & 4.52 & 4.51 & 4.51 \\
14R-2, 32-34 & 179.16 & 5.48 & 5.41 & 5.38 \\
14R-2, 121-123 & 180.05 & 4.42 & 4.42 & 4.45 \\
15R-1, 7-9 & 182.26 & 4.26 & 4.33 & 4.32 \\
16R-1, 41-43 & 187.41 & 4.33 & 4.35 & 4.35 \\
16R-2, 89-91 & 188.85 & 4.53 & 4.49 & 4.48 \\
\hline & & & & \\
\hline
\end{tabular}

Note: Values are accurate to $\pm 20 \mathrm{~m} / \mathrm{s}$. 
Table T10. Thermal conductivity measurements, Site U1346. (See table note.)

\begin{tabular}{lccc}
\hline $\begin{array}{c}\text { Core, section, } \\
\text { interval }(\mathrm{cm})\end{array}$ & $\begin{array}{c}\text { Top depth } \\
\text { (mbsf) }\end{array}$ & $\begin{array}{c}\text { Thermal } \\
\text { conductivity } \\
(\mathrm{W} /[\mathrm{m} \cdot \mathrm{K}])\end{array}$ & $2 \sigma$ \\
\hline 324-U1346A- & & & \\
4R-1, 0-17 & 119.5 & 1.371 & 0.041 \\
6R-2, 0-19.5 & 140.3 & 1.564 & 0.010 \\
7R-1, 78-101 & 142.6 & 1.514 & 0.031 \\
8R-2, 69-94 & 150.7 & 1.602 & 0.220 \\
9R-2, 73-116 & 155.6 & 1.431 & 0.017 \\
10R-1, 13-36 & 158.4 & 1.680 & 0.040 \\
12R-1, 9-24 & 168.0 & 1.506 & 0.005 \\
12R-2, 0-16 & 168.0 & 1.546 & 0.014 \\
13R-1, 99-127 & 173.5 & 1.671 & 0.019 \\
13R-1, 53-64 & 174.3 & 1.578 & 0.039 \\
14R-1, 0-17.5 & 177.4 & 1.407 & 0.011 \\
14R-2, 104-118 & 179.9 & 1.484 & 0.014 \\
16R-1, 9-24 & 187.1 & 1.406 & 0.012 \\
\hline
\end{tabular}

Note: Values are averages of at least four measurements.

Table T11. Demagnetization results for basalt samples, Site U1346. (See table notes.)

\begin{tabular}{|c|c|c|c|c|c|c|c|c|c|}
\hline \multirow{2}{*}{$\begin{array}{l}\text { Core, section, } \\
\text { interval }(\mathrm{cm})\end{array}$} & \multicolumn{2}{|c|}{ Depth (mbsf) } & \multirow[b]{2}{*}{ Demagnetization } & \multicolumn{2}{|c|}{ Fit } & \multirow[b]{2}{*}{$N$} & \multirow{2}{*}{$\begin{array}{c}\text { Inclination } \\
\left({ }^{\circ}\right)\end{array}$} & \multirow{2}{*}{$\begin{array}{c}\text { Declination } \\
\left({ }^{\circ}\right)\end{array}$} & \multirow{2}{*}{$\begin{array}{c}\text { MAD } \\
\left({ }^{\circ}\right)\end{array}$} \\
\hline & Top & Bottom & & ${ }^{\circ} \mathrm{C}$ & $\mathrm{mT}$ & & & & \\
\hline \multicolumn{10}{|l|}{ 324-U1346A- } \\
\hline 6R-1, 111-113 & 140.01 & 140.03 & $\mathrm{TH}$ & $300-475$ & & 6 & -26.4 & -169.3 & 1.7 \\
\hline $7 R-1,53.5-55.5$ & 142.24 & 142.26 & $\mathrm{TH}$ & $300-475$ & & 6 & -20.5 & 49.8 & 2.4 \\
\hline 7R-1, 92-94 & 142.62 & 142.64 & $\mathrm{TH}$ & $300-425$ & & 4 & -9.8 & 133.2 & 2.3 \\
\hline $7 \mathrm{R}-2,39-41$ & 143.50 & 143.52 & $\mathrm{AF}$ & & $10-60$ & 8 & -19.0 & 124.6 & 0.8 \\
\hline $7 R-4,12-14$ & 145.59 & 145.61 & $\mathrm{TH}$ & $300-425$ & & 4 & -25.7 & 34.1 & 1.5 \\
\hline $8 R-1,29.5-31.5$ & 148.90 & 148.92 & $\mathrm{TH}$ & $300-450$ & & 6 & -16.6 & 29.5 & 3.0 \\
\hline $8 \mathrm{R}-2,11-13$ & 150.13 & 150.15 & $\mathrm{TH}$ & $200-525$ & & 9 & -18.9 & -59.2 & 3.0 \\
\hline 9R-2, 95-98 & 155.78 & 155.81 & $\mathrm{TH}$ & $300-450$ & & 5 & -13.4 & 155.7 & 3.3 \\
\hline 9R-2, 127-129 & 156.10 & 156.12 & $\mathrm{TH}$ & & & & & & \\
\hline $10 \mathrm{R}-1,21.5-23.5$ & 158.42 & 158.44 & $\mathrm{AF}$ & & $10-100$ & 11 & -20.8 & 90.7 & 3.6 \\
\hline 11R-1, 35-37 & 163.35 & 163.37 & $\mathrm{TH}$ & $300-450$ & & 6 & -17.7 & -97.3 & 6.2 \\
\hline $12 \mathrm{R}-2,2-4$ & 168.06 & 168.08 & $\mathrm{TH}$ & & & & & & \\
\hline $13 R-1,76-78$ & 173.26 & 173.28 & $\mathrm{TH}$ & $300-500$ & & 8 & -21.5 & 136.4 & 3.0 \\
\hline $13 \mathrm{R}-2,38-41$ & 174.15 & 174.18 & $\mathrm{AF}$ & & $10-100$ & 11 & -15.7 & 30.3 & 1.6 \\
\hline $14 \mathrm{R}-1,14-16$ & 177.54 & 177.56 & $\mathrm{TH}$ & $300-500$ & & 7 & -22.3 & -151.7 & 1.6 \\
\hline $14 \mathrm{R}-2,32-34$ & 179.16 & 179.18 & $\mathrm{TH}$ & $100-525$ & & 11 & -24.1 & -21.7 & 1.7 \\
\hline $14 \mathrm{R}-2,121-123$ & 180.05 & 180.07 & $\mathrm{TH}$ & $100-475$ & & 9 & -24.3 & -21.4 & 2.2 \\
\hline $15 \mathrm{R}-1,6-9$ & 182.26 & 182.29 & $\mathrm{AF}$ & & $10-80$ & 10 & -17.2 & -17.5 & 0.7 \\
\hline $16 \mathrm{R}-1,41-43$ & 187.41 & 187.43 & $\mathrm{TH}$ & & & & & & \\
\hline 16R-2, 89-91 & 188.85 & 188.87 & $\mathrm{TH}$ & $300-525$ & & 9 & -31.8 & 145.8 & 3.4 \\
\hline
\end{tabular}

Notes: For all samples, principal component analysis (PCA) is anchored to origin. $\mathrm{AF}=$ alternating-field demagnetization, $\mathrm{TH}=$ thermal demagnetization. $N=$ number of points used for PCA. MAD = maximum angular deviation.

Table T12. Logging operations, Hole U1346A. (See table notes.)

\begin{tabular}{|c|c|c|c|c|c|c|}
\hline \multirow[b]{2}{*}{ Tool string } & \multirow[b]{2}{*}{ Direction } & \multicolumn{2}{|c|}{$\begin{array}{l}\text { Interval logged } \\
\text { WMSF }(\mathrm{m})\end{array}$} & \multirow{2}{*}{$\begin{array}{l}\text { Pipe depth } \\
\operatorname{DRF}(\mathrm{m})\end{array}$} & \multirow{2}{*}{$\begin{array}{l}\text { Depth shift } \\
\text { (m) }\end{array}$} & \multirow{2}{*}{$\begin{array}{l}\text { Logging speed } \\
(\mathrm{m} / \mathrm{h})\end{array}$} \\
\hline & & Top & Bottom & & & \\
\hline \multirow[t]{3}{*}{ HNGS-HLDS-GPIT-DITE } & Downlog & 0 & 197 & 3753.5 & -3630.9 & 550 \\
\hline & Pass 1 & 150 & 178 & 3753.5 & -3630.9 & 275 \\
\hline & Pass 2 & 0 & 177.5 & 3753.5 & -3630.9 & 550 \\
\hline
\end{tabular}

Notes: Seafloor depth = 3627.4 m DRF, 3630.9 m WRF. HNGS = Hostile Environment Natural Gamma Ray Sonde, HLDS = Hostile Environment Litho-Density Sonde, GPIT = General Purpose Inclinometry Tool, DITE = Dual Induction Tool model E. 